\title{
IN THE BEAUTY
}

\section{- $\mathrm{OF}-$}

MEADOW AND MOUNTAIN

CHARLES COKE WOODS

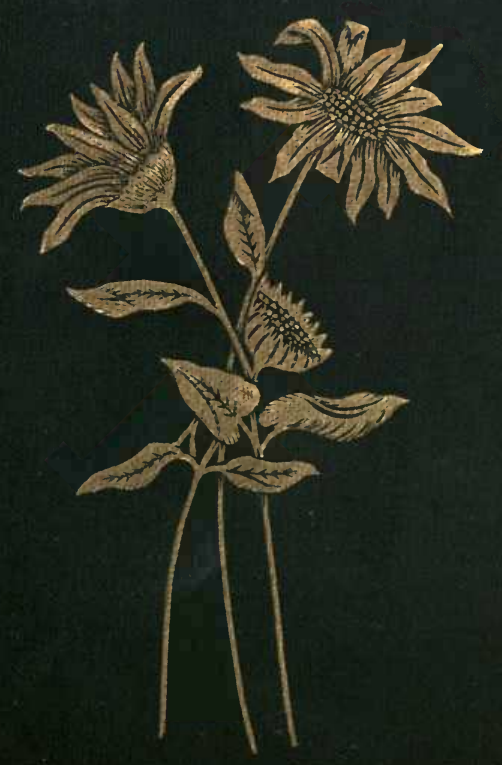




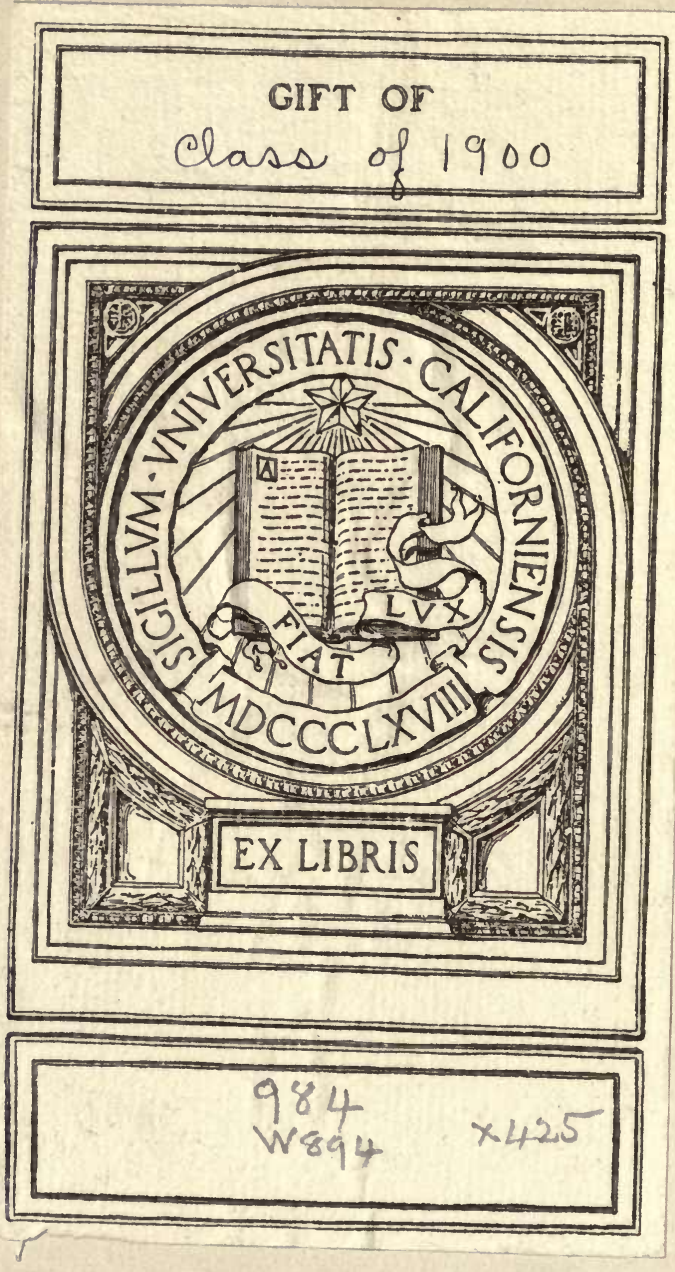






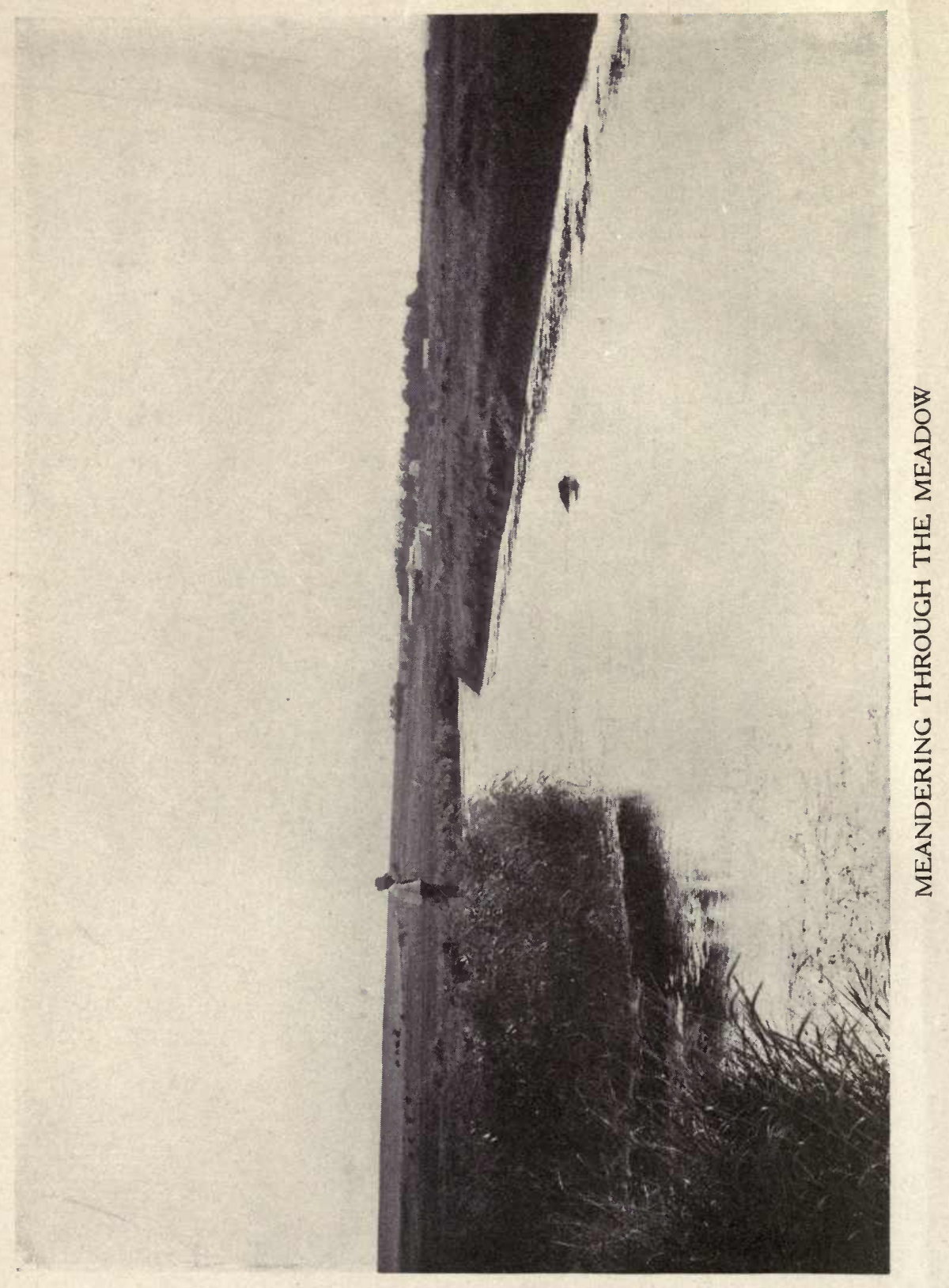




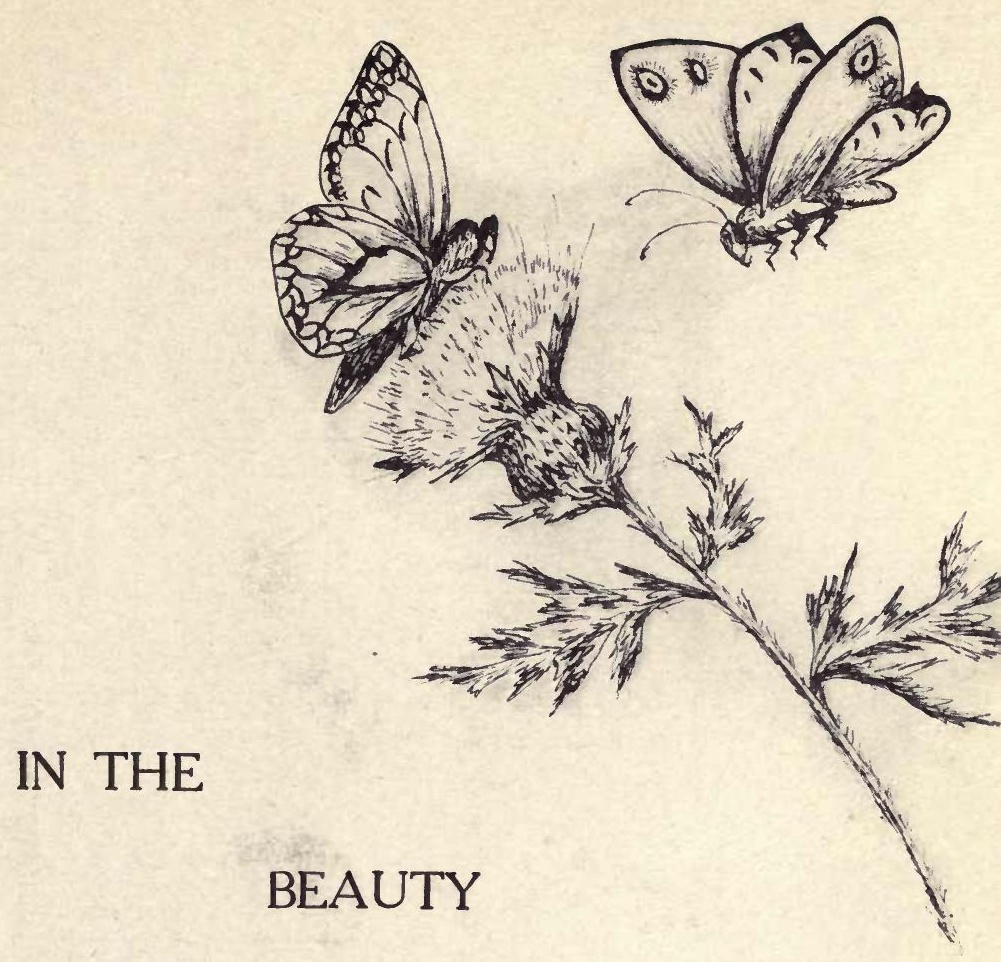

OF

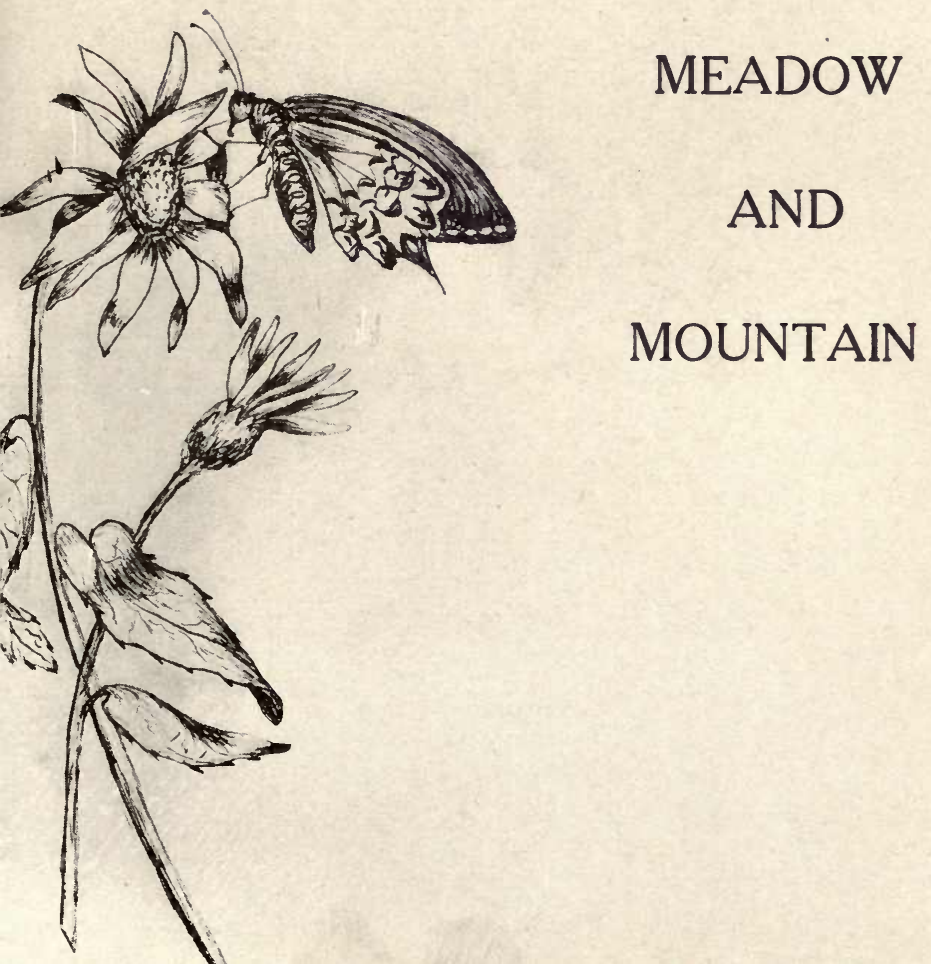



Then hail, ye hills! like rough-hewn temples set, With granite beams, upon this earth of God! -Frederic Lawrence Knowles.

\section{OF}

\section{MEADOW AND MOUNTAIN}

\section{By CHARLES COKE WOODS}

$$
\begin{aligned}
& \vdots \vdots \vdots \because \because \cdots \\
& \text { • }
\end{aligned}
$$

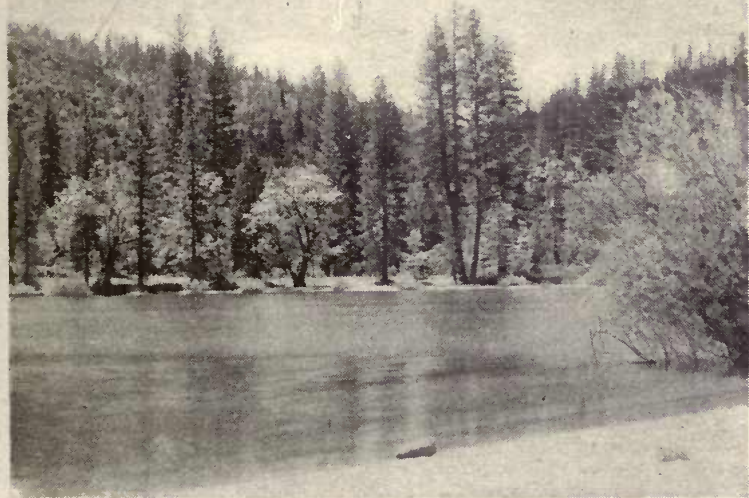

Scenes must be beautiful which daily view'd, Please daily, and whose novelty survives Long knowledge and the scrutiny of years : Praise justly due to those that I describe. -From Cowper's Landscape. 


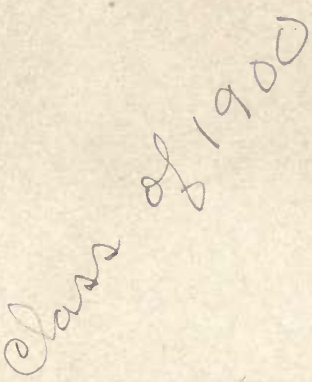

CoPYRIGHT, 1913 , BY

Jennings \& Graham

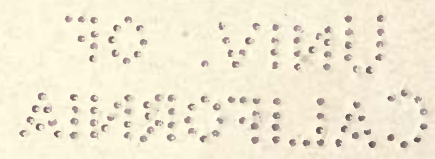


$W$
$W$

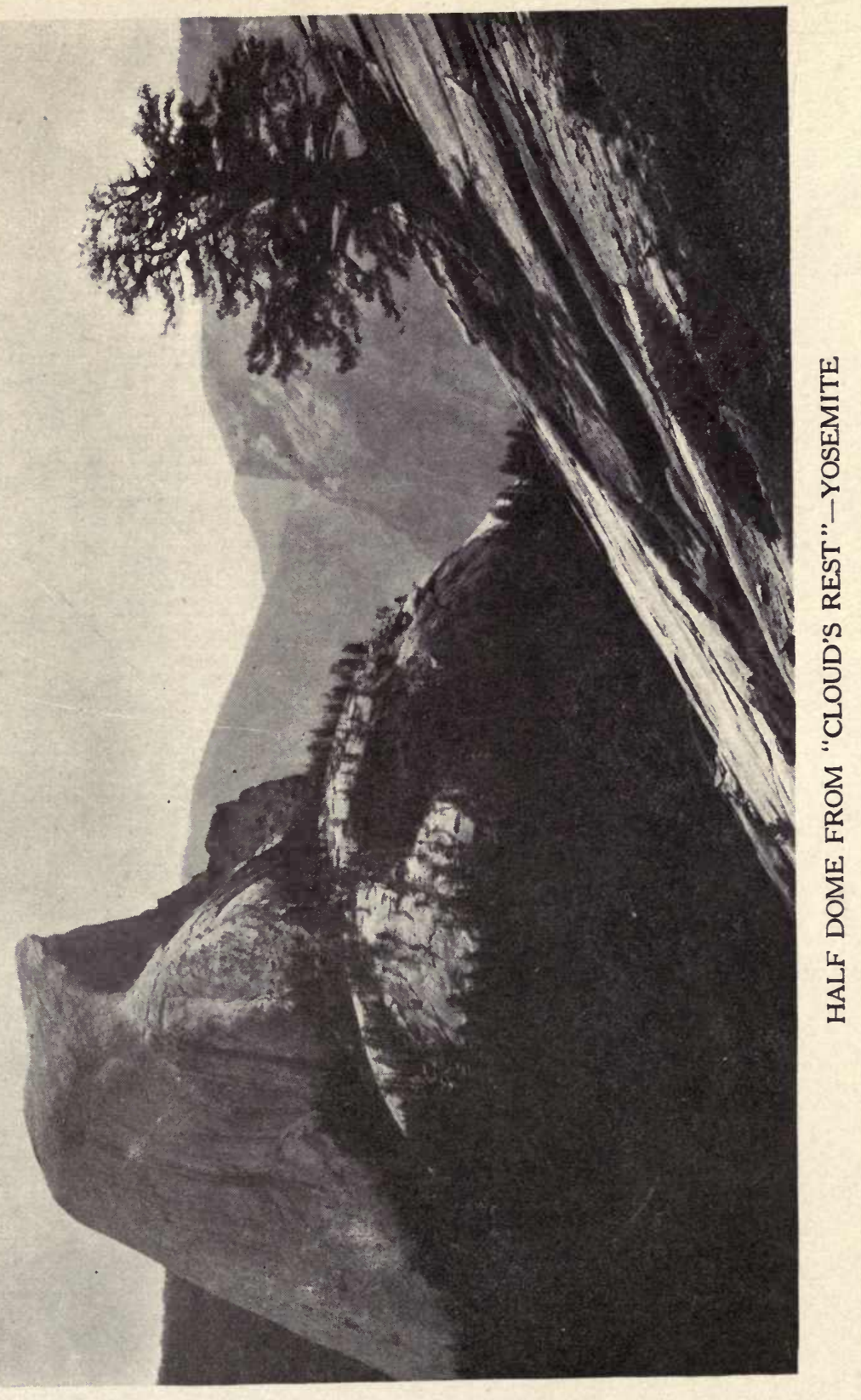


$\because \vdots \vdots \quad \because \vdots \vdots \vdots \vdots \vdots$

$\therefore \quad y_{0}$ 


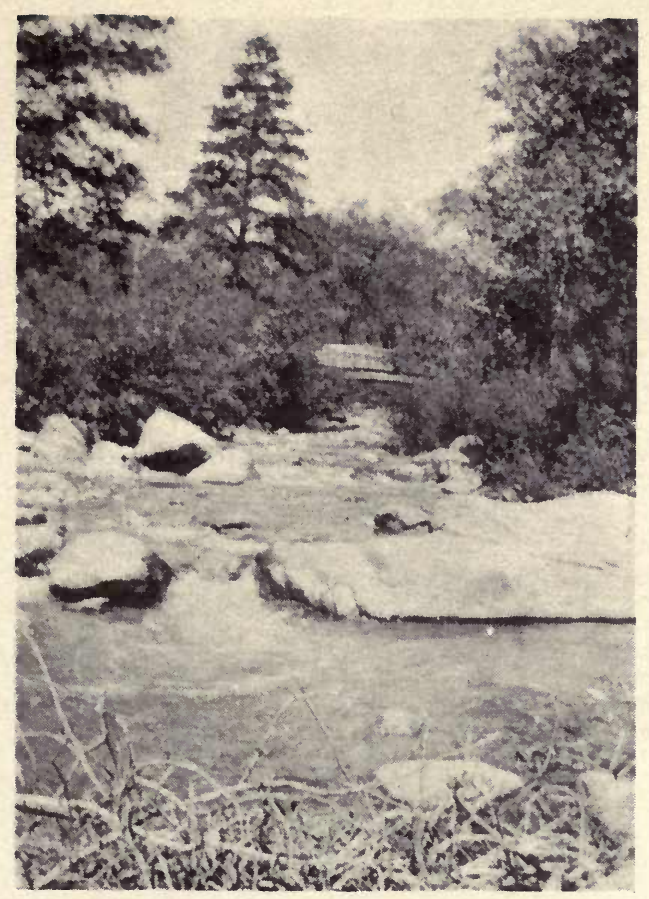

\section{CONTENTS}

PAGE.

I. Thine and Mine, . . . . . . . . . . . . . 23

II. A Word About Beauty, . . . . . . . . . . 29

III. Prairie Meadows, . . . . . . . . . . . . 39

IV. Morning Dew, . . . . . . . . . . . . 47

V. A Parable of the Trail, . . . . . . . . . 55

VI. The Harp in the Willows, . . . . . . . . 65

VII. The Wind, . . . . . . . . . . . . . . 75

VIII. Afterglow, . . . . . . . . . . . . . 87

iX. Surprises of the Prairies, . . . . . . . . . . . . 93

(1). Sunflower, . . . . . . . . . . . 104

(2). Yucca, . . . . . . . . . . . . . 109

(3). Grass, ........ . . . . . . . . . 118

(4). Prairie Dog, . . . . . . . . . . 126 


\section{Contents}

PAGE.

X. Some Beauties of the Wild, . . . . . . . . 131

(1). The Swinging Lamps of Dawn, . . . . . 135

(2). The Wild Rose, . . . . . . . . . . 136

(3). The Vine Tangle, . . . . . . . . . . 138

(4). Wild Verbena, . . . . . . . . . . 140

(5). The Prairie "Deer Apple," . . . . . . 142

XI. Mirrors of THE SKy, . . . • • • • • • . 145

The Mirage, . . . . . . . . . . . 158

XII. Rambling Rivers, . . . . . . . . . . . 161

XIII. A Bunch of Wild Flowers, . . . . . . . 187

(1). Snow on the Mountain, . . . . . . . . 191

(2). The Butterfly Weed, . . . . . . . . 193

(3). The Mallow, . . . . . . . . . . . 194

(4). Wild Potato Bloom, . . . . . . . . . 195

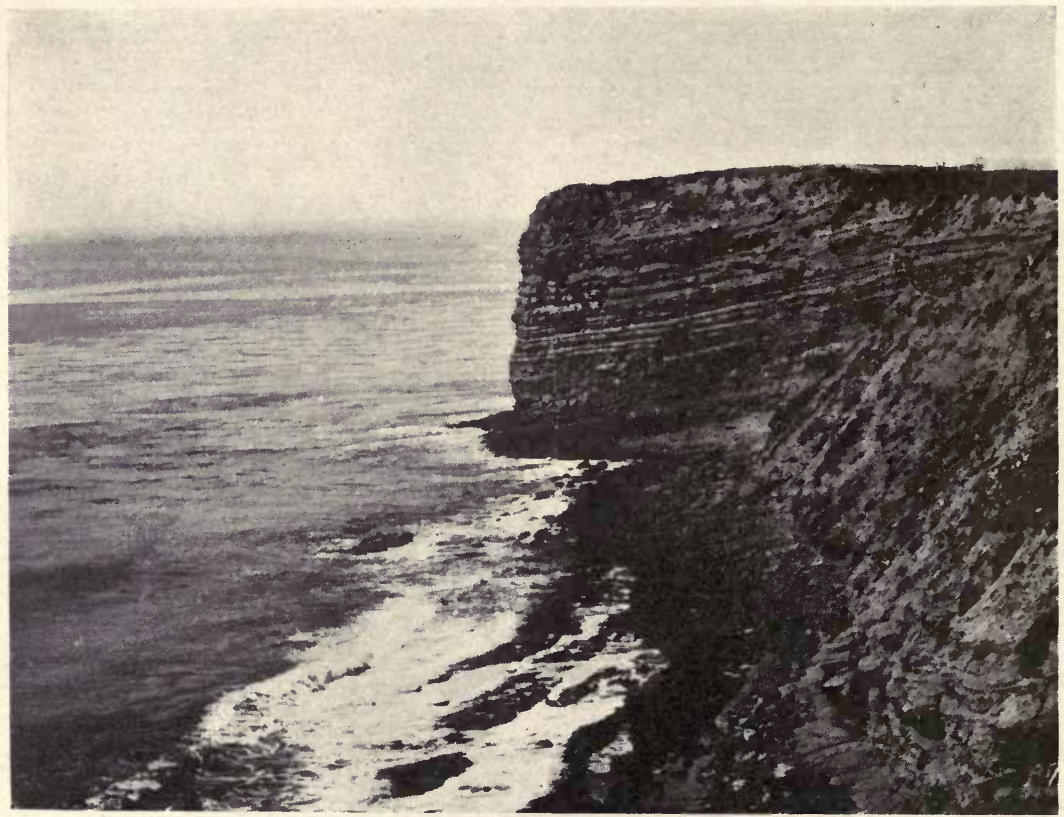




\section{Contents}

PAGE.

XIV. The Fruit of the Furrow, . . . . . . . . 197

XV. A Race for Prairie Homes, . . . . . . . . . 217

XVI. The Bridal of the Bluestem, . . . . . . . . 223

XVII. Between the Hedge Rows, . . . . . . . . 247

(1). The DAY-Flower, . . . . . . . . . . 252

(2). The Wild Petunia, . . . . . . . . 253

(3). Goldenrod, . . . . . . . . . . . 255

XVIII. WeEDS, . . . . . . . . . . . . . 257

XIX. Alfalfa, * . . . . . . . . . . . . 269

XX. The Peak Between the Prairies, . . . . . . 275

Morning on the Mountain, . . . . . . 283

XXI. A Dream in the Desert, . . . . . . . . . . 289

XXII. In CALIFornia, . . . . . . . . . . . . 305

XXIII. A Yosemite Idyl, . . . . . . . . . . . . . 311

North Dome Vista, . . . . . . . . 315

XXIV. Under the Redwood Trees, . . . . . . . . . 335

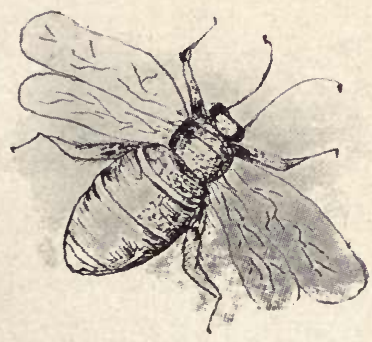




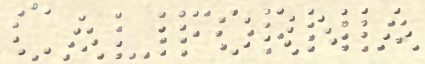

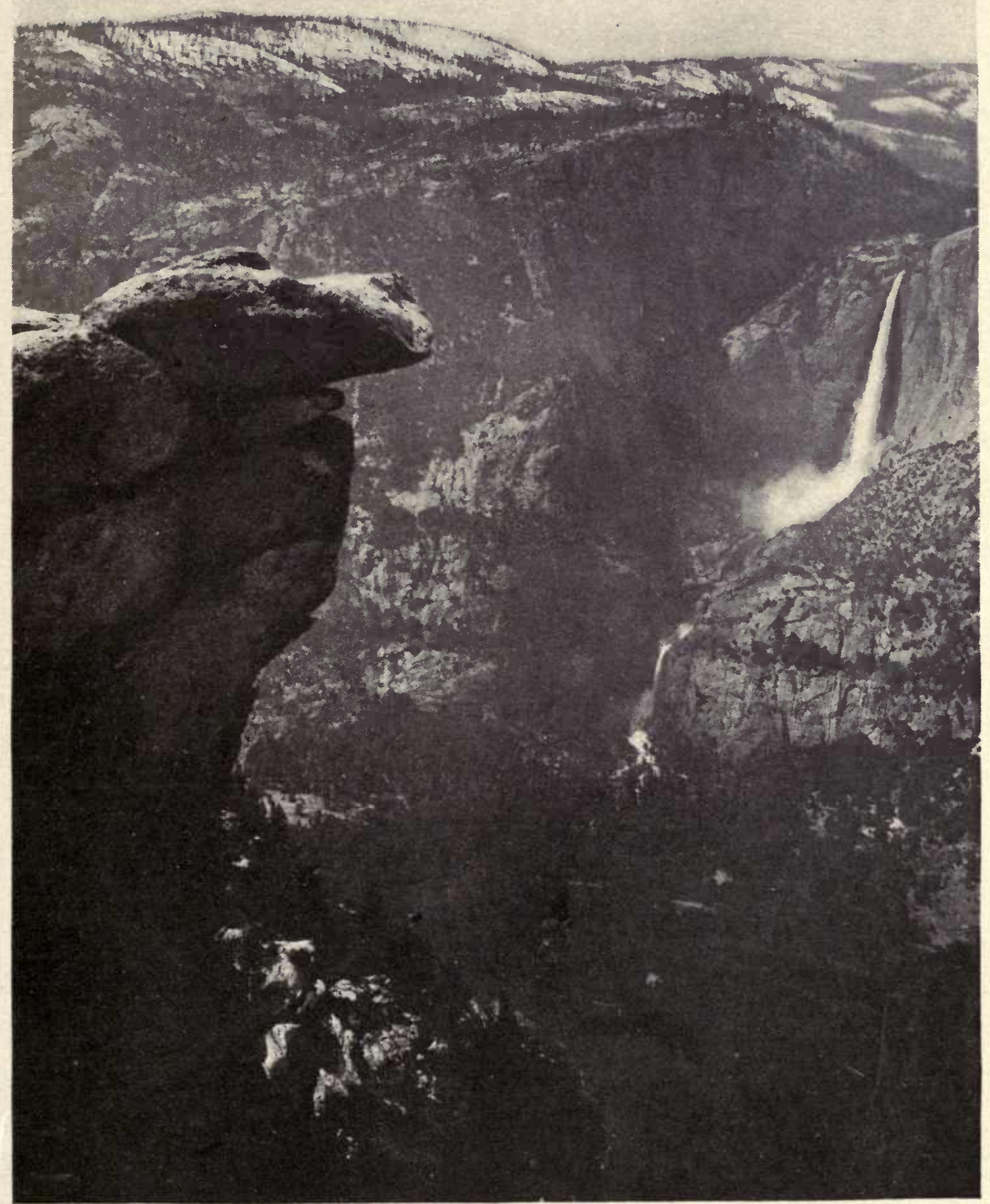

OVERHANGING ROCK AND HIGH SIERRAS 
tas 


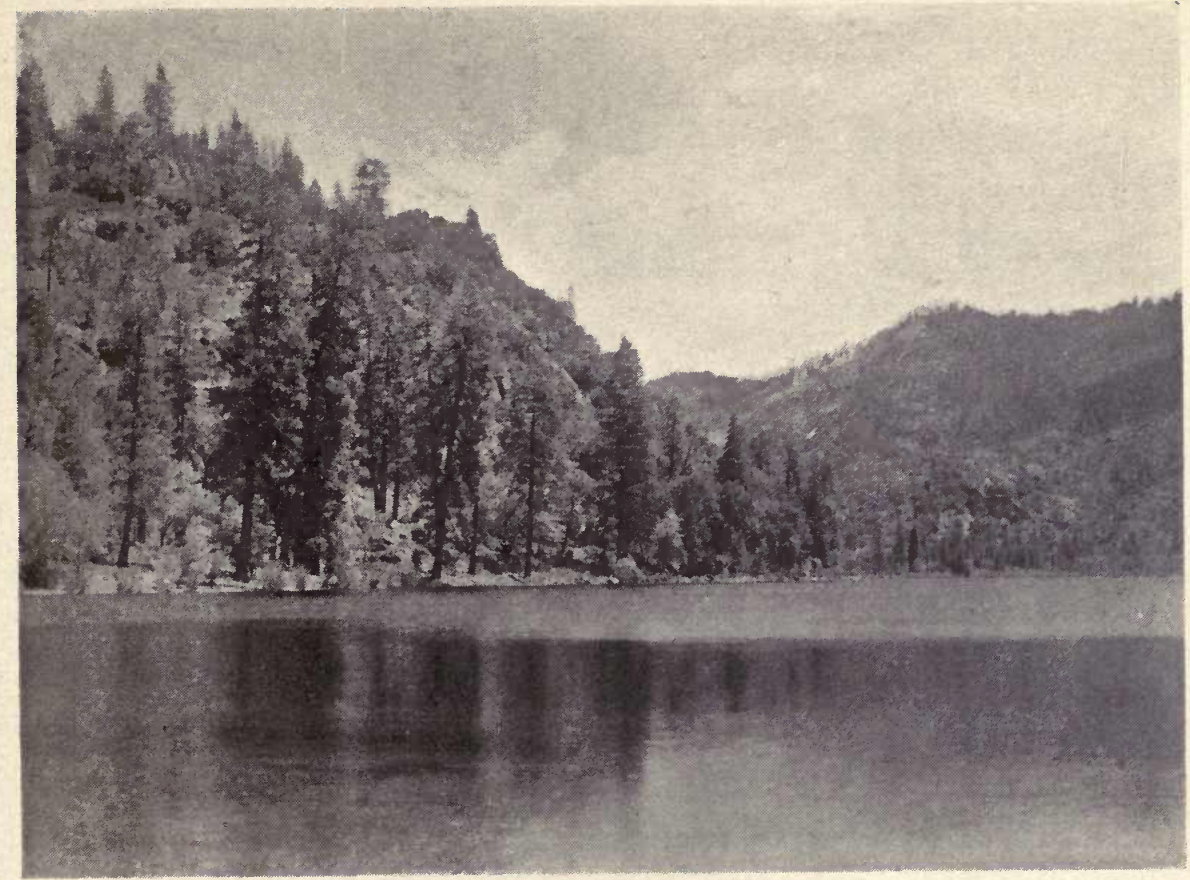

\section{PICTURED ILLUSTRATIONS}

Illustrative Artist, Almina Martindale Woods.

PAGE.

Meandering Through the Meadow,

Frontispiece, . 2

Half Dome From “Cloud's Rest," . . . . Taylor, . . 7

OverhaNGING Rock, . . . . . . . . Taylor, . . 13

"Happy Isles," . . . . . . . . . Taylor, . . 21

Beautiful Mountains, . . . . . . Taylor, . . 25

A Bank of Beauty, . . . . . . . . Croft, . . . 31

A Weather-beaten Fence, . . . . . A. M. W., . 35

Homes That Nestle There, . . . . . . . . . . . 41

Meadow Bloom, . . . . . . . . . A. M. W., . . 43

Wild ThORNy Poppy, . . . . . . . A. M. W., . . 44

Nesting Time, . . . . . . . . . . A. M. W., . . 45 


\section{Pictured Illustrations}

A Brood of Bobwhites,

PAGE.

Placid Lakes,

A. M. W.,

Cactus,

"The Slumbering Trail,"

A. M. W., . . 53

The Ranchman's Lonely LandmaRk, A. $M . W .$, . $\quad 57$

Prairie Schooner,

Croft,

The Road to the River,

Goddard,

A Sod House,

Martindale,

61

"Where Cattle Dozed and Dreamed,"

A Place to Dream,

Croft,

64

Among the Drifting Leaves,

Stockenberg,

Windwork on the Mountains,

Foley,

Serenely Gliding Waters,

Stockenberg, . 89

The Walnut River, .

A. M. W., . . 95

Mysterious Masonry,

Martindale,

99

SUNFLOWER,

A. $M . W$.,

105

The Yucca Bloom,

A. M.W., . . 109

Sweet William,

The Wild Silver Sage,

The Sage Hen

The Salvia,

A. M. W.

Bunch Grass,

A. M. W.,

Buffalo,

The Racer of the Range,

Prairie Dog,

A. $M . W$. 126

Tenting on the Prairie,

A Lone Tepee,

Croft,

DeER,

Oppossum,

A. M. W.

The Swinging Lamps of Dawn,

A. $M . W$.

The Wild Rose,

A. M. W.,

Storm-Disheveled Vine,

A. M. W., . 


\section{Pictured Illustrations}

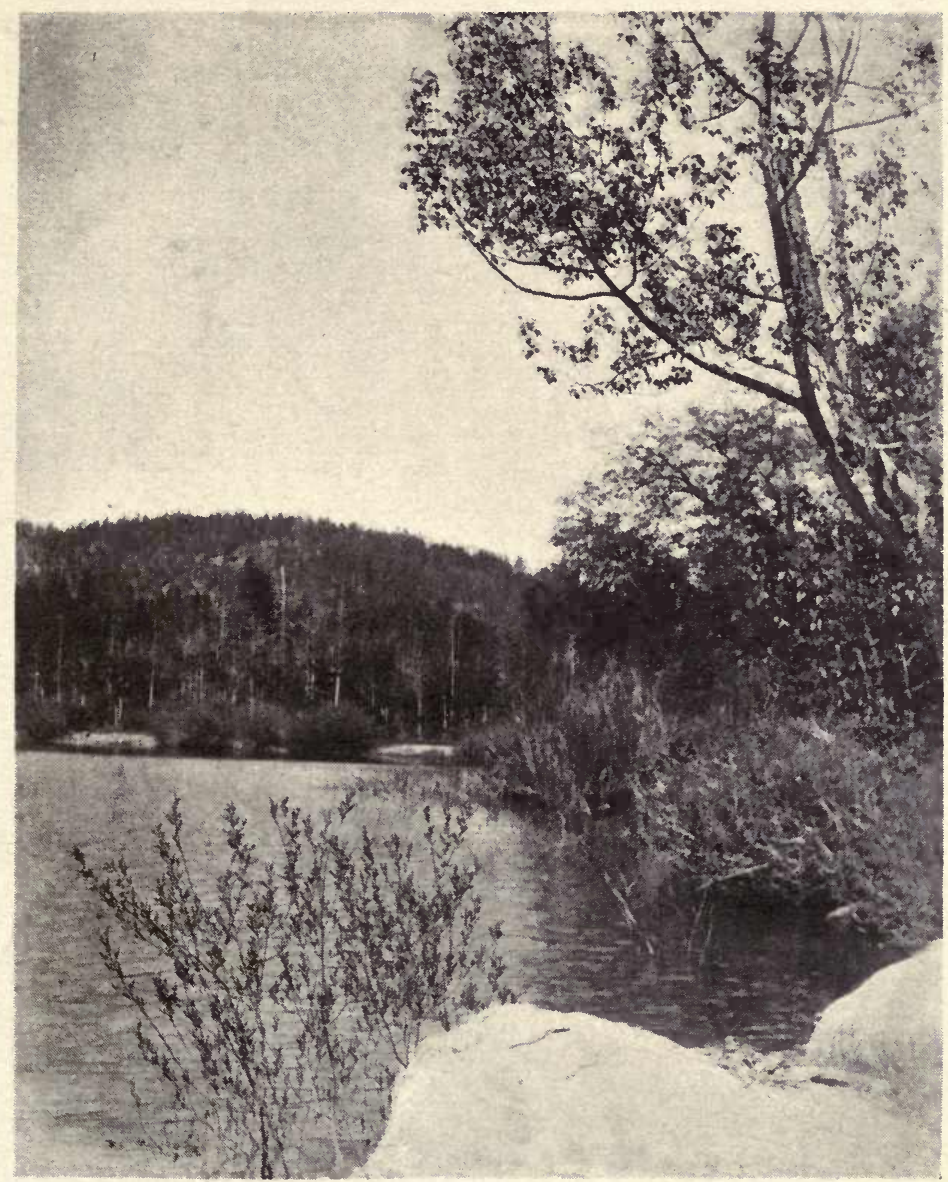

PAGE.

The Wild Verbena, . . . . . . . . Croft, . . . 141

The Deer Apple, . . . . . . . . . A. M. W., . . 143

One of Nature's Mirrors, . . . . . Lisenby, . . 147

The Browsing Herd, . . . . . . . . . . . . . 151

Mirror Lake, . . . . . . . . . . Taylor, . . 155

Mist on the Hills, . . . . . . . . . Croft, . . . 157

"As Its Waters Lave on a Shining Shore," . . . . . . 159 


\section{Pictured Illustrations}

"Only a Ghost of a Green-clad Vale,"

PAGE.

The River of Dreams,

A. M. W., .

159

Gleam and Shadow,

Goddard,

163

"Tired of the Din of Its Own Dashings,"

Martindale, 165

"Between Banks of White,"

Goddard,

166

"It Would Hush Its Murmurings,"

Martindale,

167

A Springtime River, A. M. W., 169

The Sмоку,

A. $M . W$. ,

A River Asleep,

A. $M . W$.

173

SALT FORK,

A. M. W.,

175

A Sunglade on the River,

Stockenberg,

177

Feasting,

A. M. W., .

179

At Home,

182

The River Mill,

183

At THE RIVER-BEND,

Ward,

185

"SNow on the Mountain,"

Ward,

189

The Butterfly Weed,

A. M. W., .

191

The Mallow, .

A. M. W.,

192

Wild Potato Bloom,

A. $M . W$.

. 194

Happy in the HaRvest Field,

A. $M . W$.

. 195

The Harvest of the Plow,

Croft,

. 199

Winesaps and Pippins,

A. M. W., .

. 203

"Maize in Full Tassel,"

Cornish,

. 207

“To See the Hopper Piled Above the Rim,"

A. M. W.,

210

REsting,

A. $M . W$. ,

. 211

The Song of the Sickle,

Croft,

213

A Race for Prairie Homes,

Croft,

215

A Sod House Home,

A. $M . W$.

219

Bluestem,

A. $M . W \cdot$

222

YuCCA,

C. C. W.,

225

"Draped About with Many Snowy Blossoms,"

Croft,

- 228

Primrose, .

A. M. W., .

229

231 


\section{Pictured Illustrations}

DRINKING IN THE DRAW,

PAGE.

The Sensitive Rose,

The Blazing Star,

Ward, . . 235

BlosSOM-Crowned,

A. $M . W$.

237

A. M. W., . . 238

"Under the Open Sky the Cowboy Sits Astride His Pony," . 243

Weary Waters, 245

Dusk in the Hedge Row, . . . . . . . A. M. W., . . 249

A Country lane,

A. M. W., .

The Day Flower, A. M. W., . 252

The Wild Petunia, A. $M . W$. 253

GoldenRod, A. M. W., 254

Tumbling Weed, A. M. W., 259

Smart Weed, A. M. W., 263

Weeds in Winter, Parker, 265

WeEds, . A. M. W., 267

Alfalfa, A. $M . W$. 271

Laughing Rivers, Martindale, . 277 "High Dominions," Taylor, 281

In THE Mountain Snow, 285

"A Coyote's Call,".

A. M. W., . 291 Cascades, 295

"And Rivers That Swirl and Roll," A. M. W., . 298 "With Clouds of Smoky Mane," 299

Musical Waters, 303

Pampas Grass, 307

Orange Blossoms, 307

California Poppy, Robert Woods, . 309

Bridal Veil-Yosemite, 313

North Dome-Yosemite, Taylor 315

Merced River, Hovey, $\begin{array}{ll}\text { A. M. W., . } & .316 \\ \text { Taylor, . . } & .317\end{array}$

El Capitan-Yosemite, Upper Yosemite Falls Taylor, . Lisenby, $\begin{array}{ll}\text { A. M. W., . } & 316 \\ \text { Taylor, . . } & \text {. } 317\end{array}$ - Taylor, . 321 


\section{Pictured Illustrations}

PAGE.

"The Three Brothers," . . . . . . . Taylor, . . . 323

"Lost Arrow Trail"-Yosemite," . . . . A. M. W., . . 325

Spruce Trunk, . . . . . . . . . . Little, . . . 326

Merced in the Trees, . . . . . . . . Taylor, . . 327

"Shadows Sleep Along the Slopes," . . . E. M. W., . . 329

Royal Arches, . . . . . . . . . . Taylor, . . . 331

Vernal Falls-Yosemite . . . . . . . E. M. W., . . 333

Nevada Falls-Yosemite, . . . . . . W. G. W., . . 333

Grizzly Giant (Redwood Tree), . . . . Lisenby, . . 337

"Under the Redwood Trees," . . . . . Lisenby, . . 340

RedWood TreEs, . . . . . . . . . W. G. W., . . 341

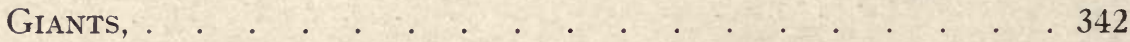

Morning on the High Sierras, . . . . . E. M. W., . . 343

A Redwood Cone, . . . . . . . . . R. W., . . . 344

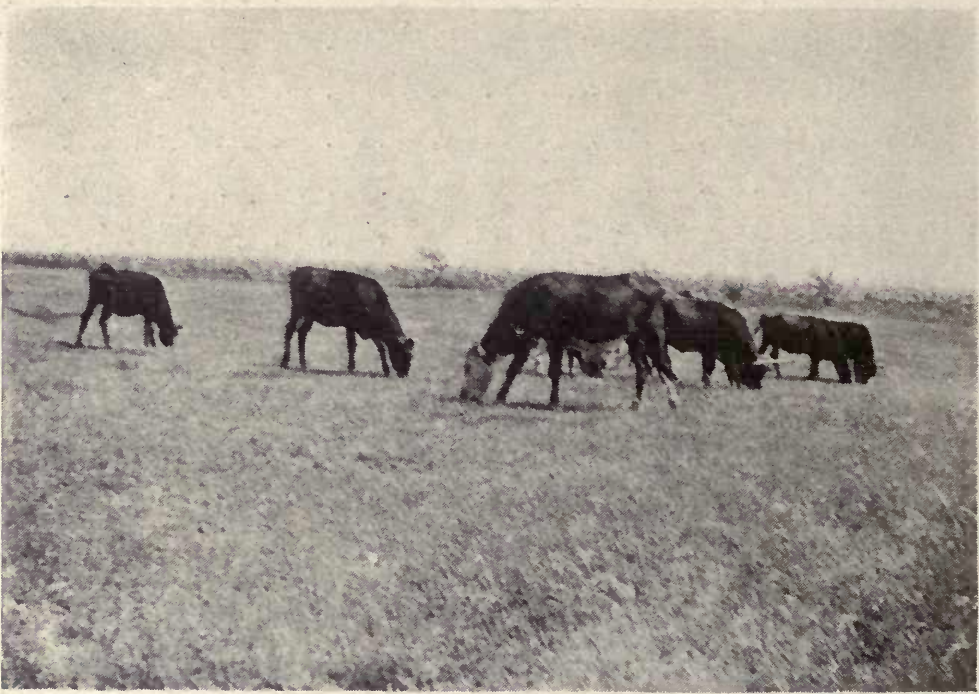




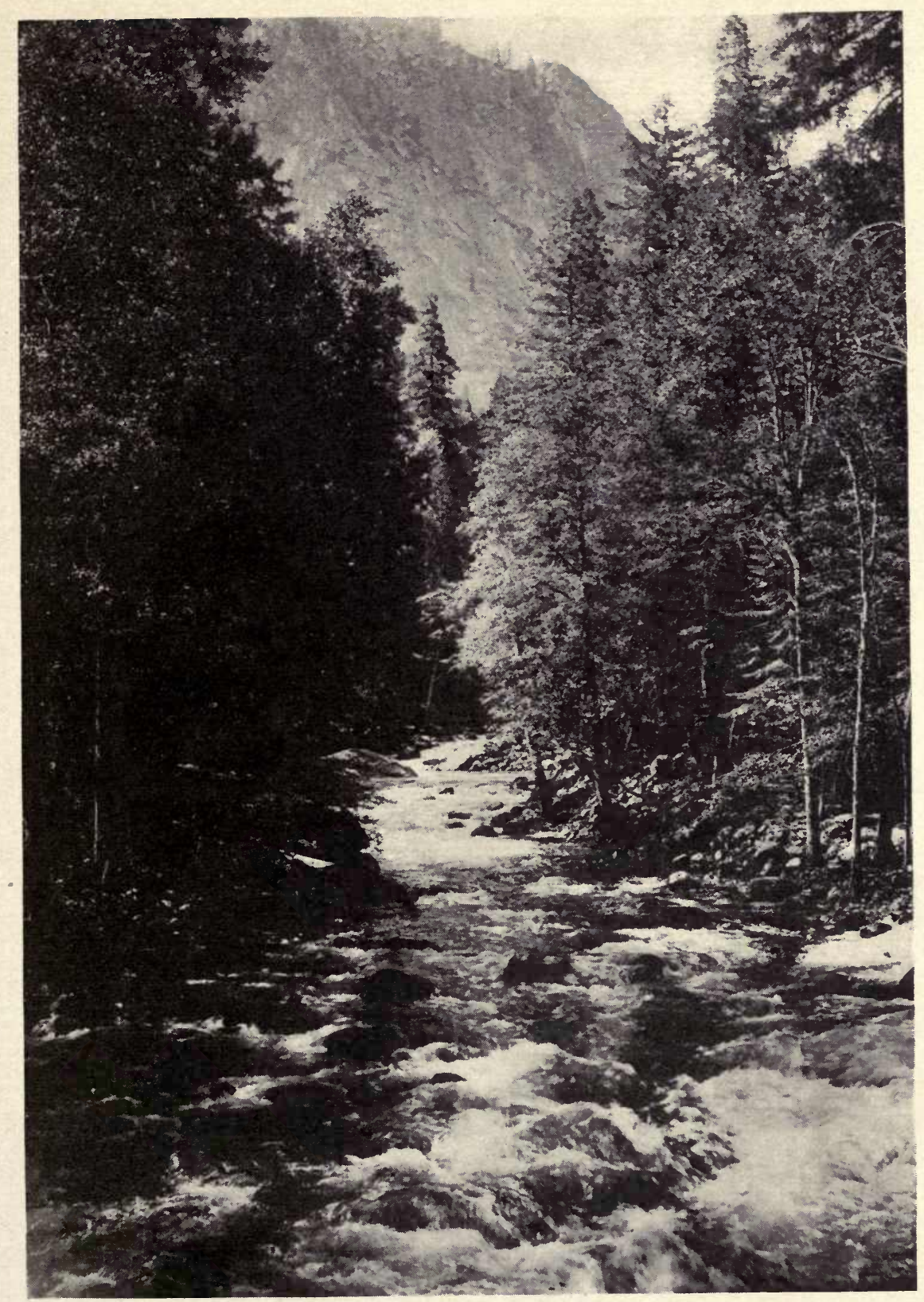

HAPPY ISLES-YOSEMITE 


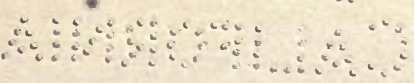




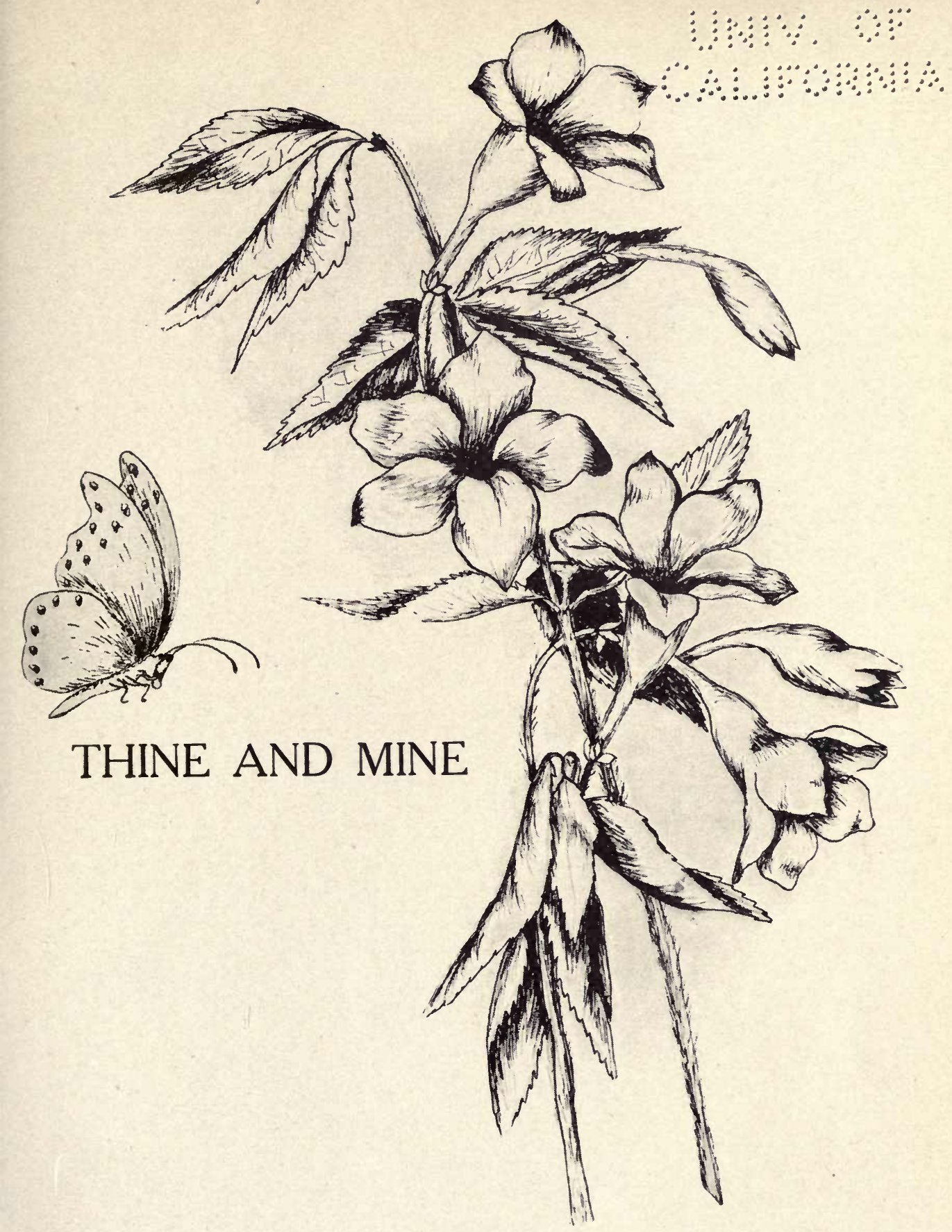


$\because \because \because \quad \therefore \because \vdots \because \vdots \vdots \vdots$

$\therefore \vdots \vdots \because \because \because \square^{\circ} \because \vdots \vdots \vdots \vdots \square_{0} \cdots$ 


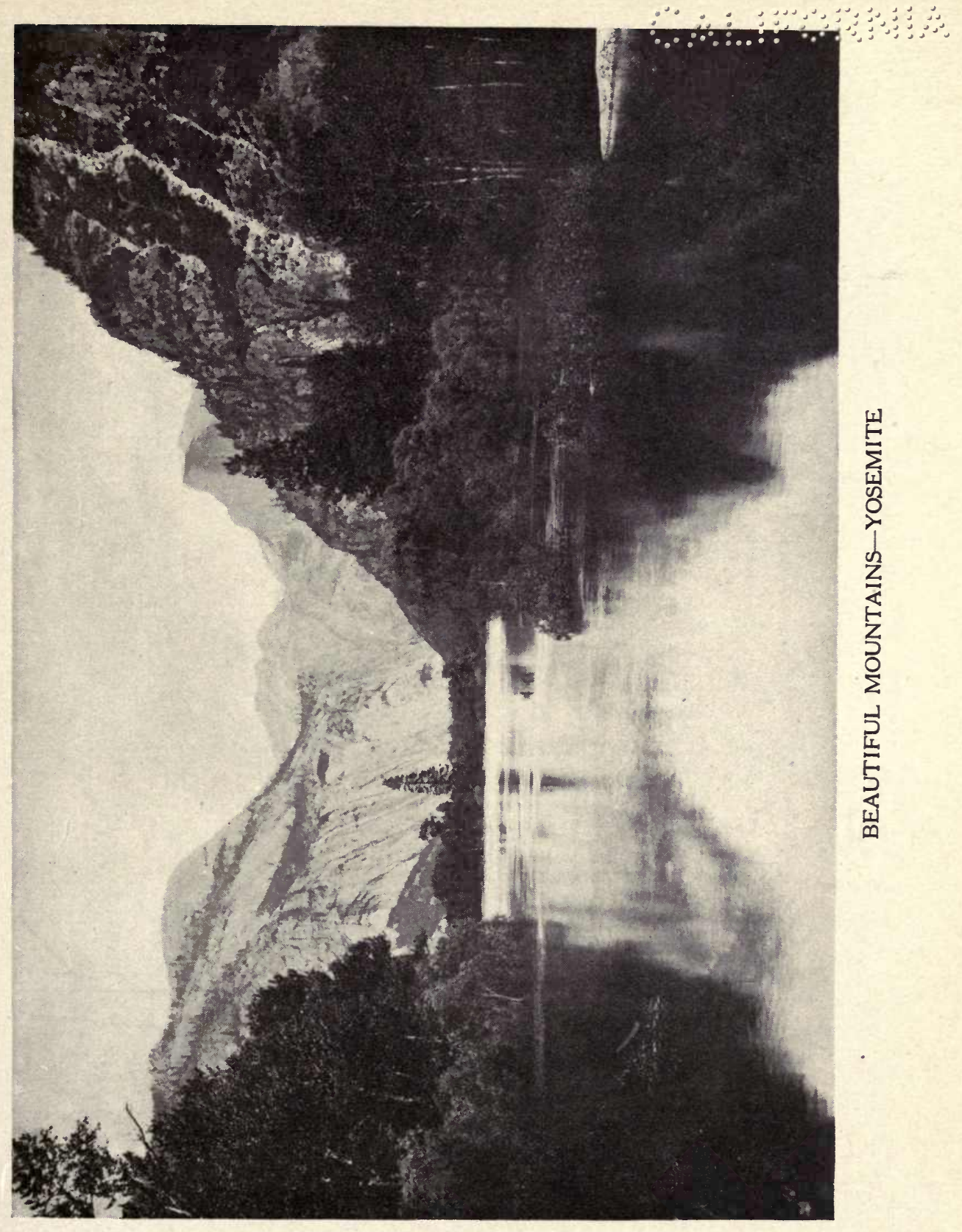


$\because \vdots \vdots \quad \vdots \vdots \vdots \vdots \vdots \vdots \vdots \vdots$

$\therefore \vdots \vdots \because \because \because \because \because \vdots \quad \vdots \therefore \cdots \square$ 


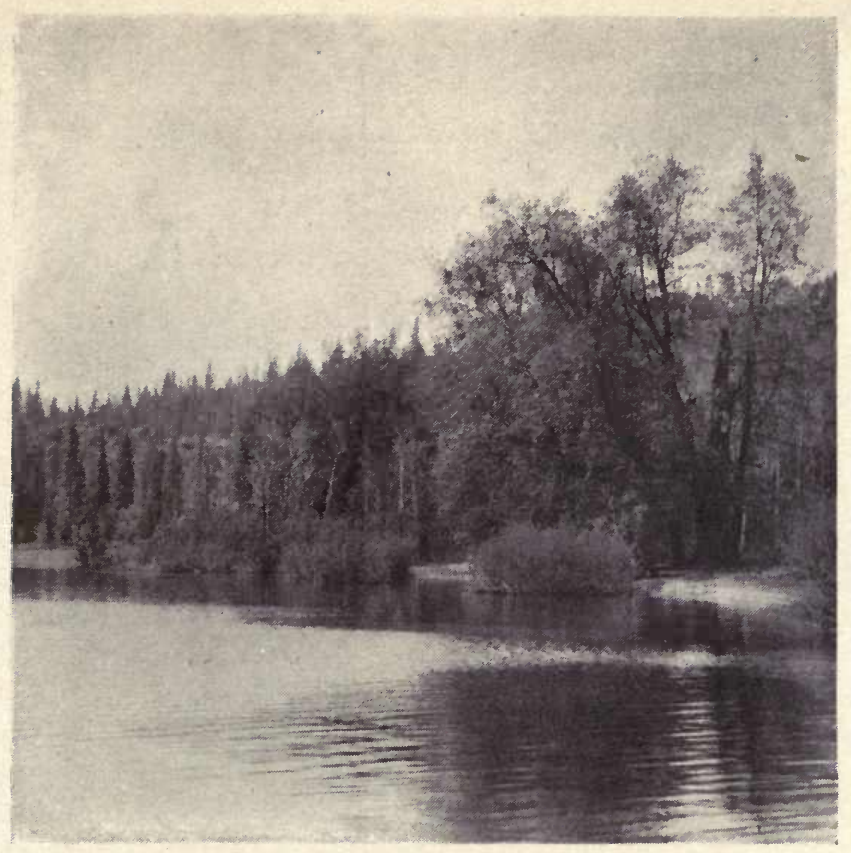

\section{THINE AND MINE}

Gleaming through shadows of dusk-woven gloom, In silvery mists o'er verdure and bloom, Through dreamful nights they shimmer and shineThey are thine, they are mine-

- The stars and the moon.

Over the hills and the dew-damp vale, When stars and moon are faded and pale, The dawn-light laves each flower and vineThey are thine, they are mineThe dawn and the dew.

The widespread range with tortuous trail, O'er reaches of meadow and stretches of swale, 


\section{Meadow and Mountain}

Prairie primroses and mountainous pineThey are thine, they are mine,

Primroses and pine.

The mountains that echo the soul in their voice,

Melodious waters that moan and rejoice,

The wind and the world, and the great sky are thineThey are thine, they are mine,

The soul and the sky.

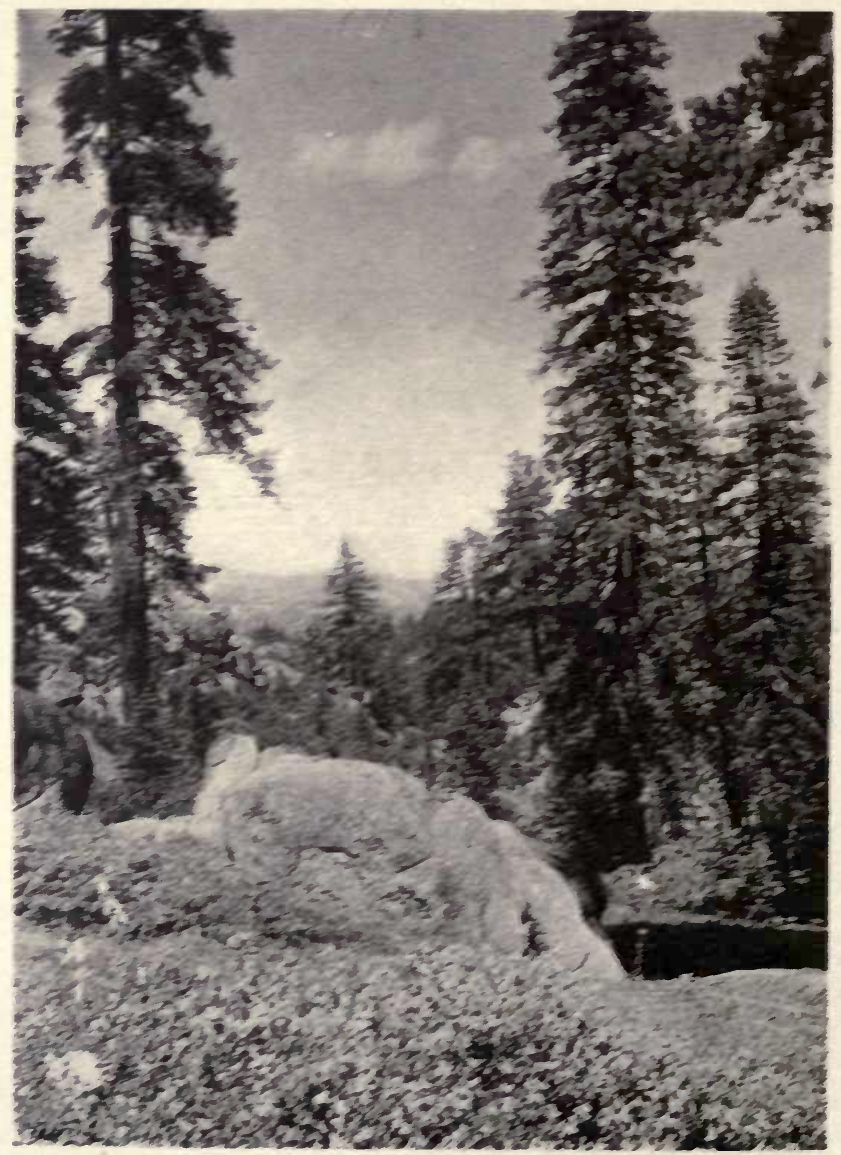




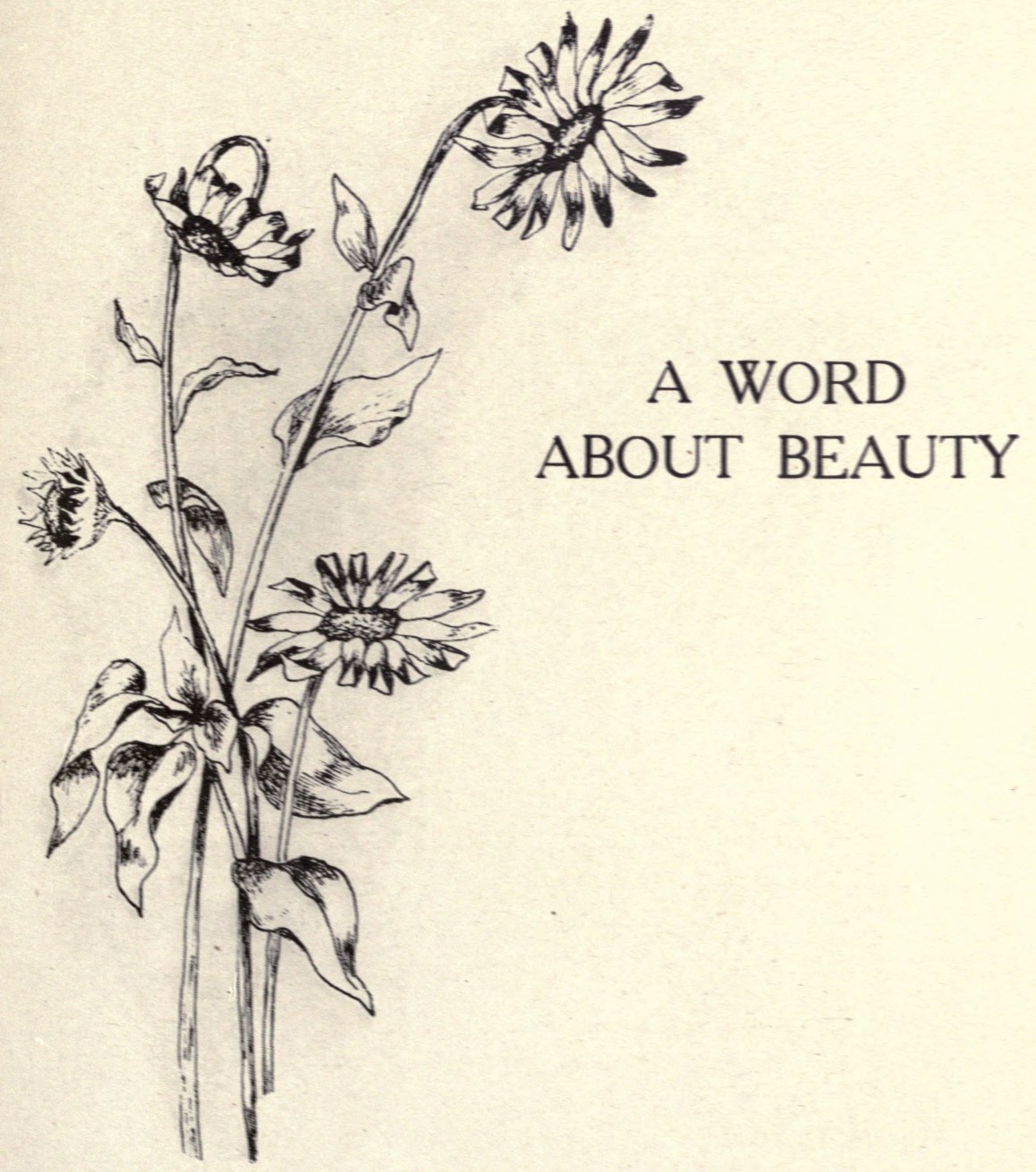


- $\because \vdots \quad \because \vdots 3 \vdots \vdots$

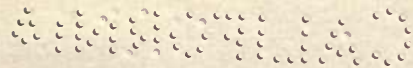




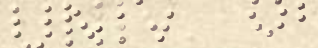

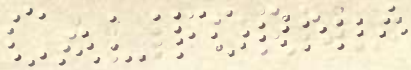

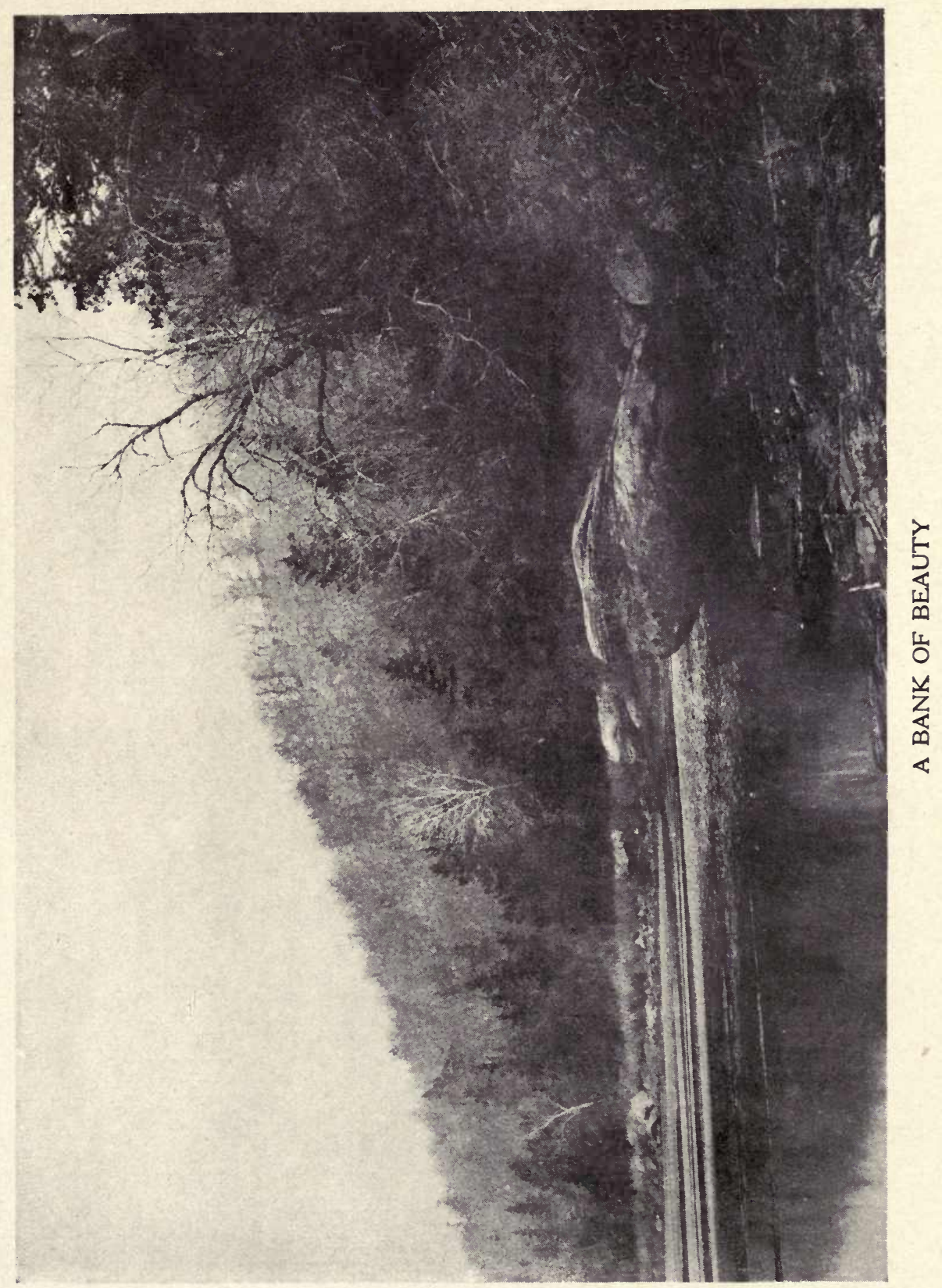


$\because \because=\quad \because \because 3 \vdots \vdots$

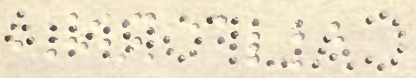




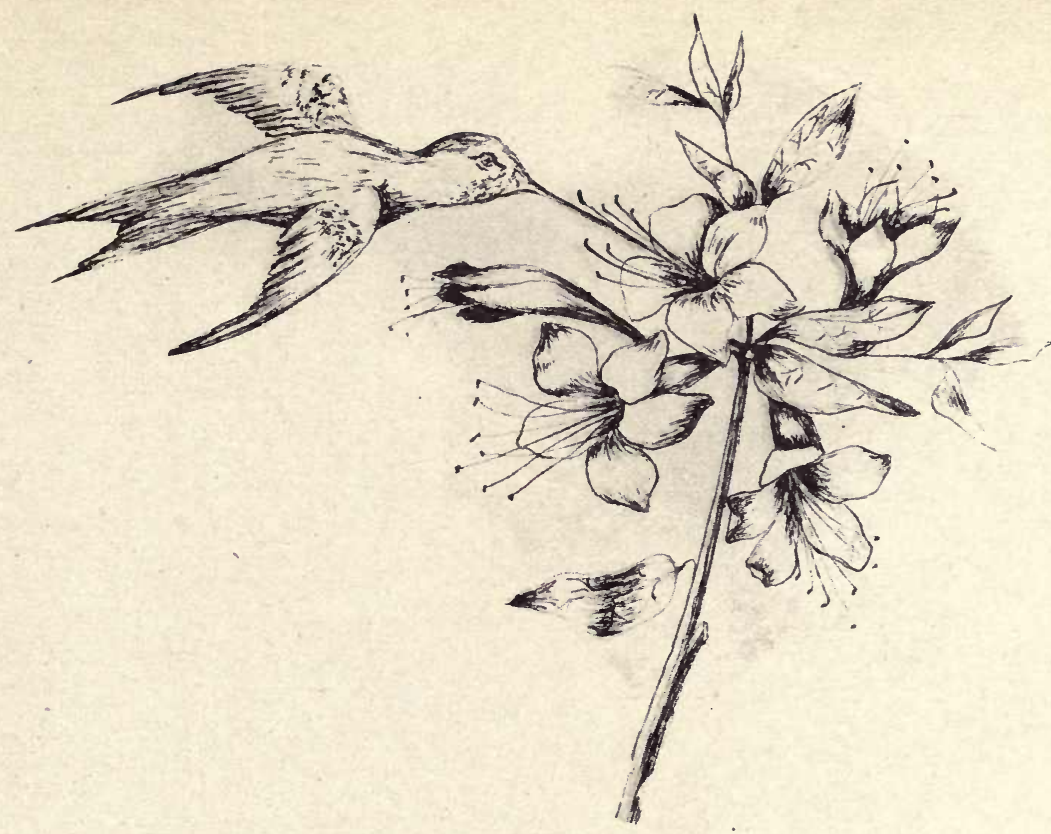

\section{A WORD ABOUT BEAUTY}

"The Garden of the Gods" may be local, but the gardens of God are everywhere. Beauty is wide-flung over the face of the earth and the sky; it is an outstanding feature of the world. Beauty is in bushes and trees and grasses, in mountains and meadows, in star and sky and sea, in the gorges of the canyons as well as in the greening garth.

It is not fancy, but sober fact, to say that beauty is everywhere. "He hath made everything BEAUTIFUL in His time." The touches of Beauty's brushes are traceable everywhere. She is sketching out on the seas and across the skies. She is out painting on the high hills and in the valleys. O, Friend of Mine! lift up your eyes and see, or lower your eyelids and look, for the exquisite touches of a Divine Artistry are everywhere. 


\section{Meadow and Mountain}

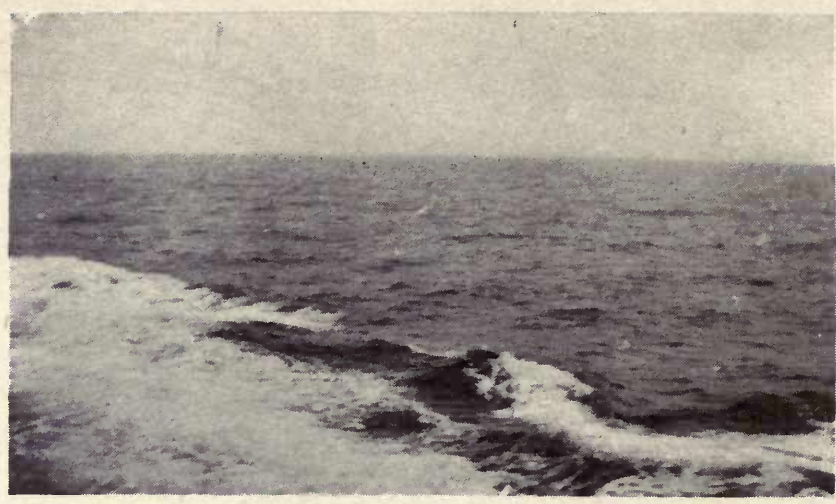

The other day a man went to gather "Moonstones" among the sea-sands. He had lived for fifty years. For many years he had lived almost in sight of the sea. Coming home one day lately, he said with a sense of subdued wonder, "I have lived years by the sea, but I did not know that all the while it was so wonderful!" In hearing of it all, but he had not heard the wondrous singing of the sea; in sight of the beautiful sea, but he had not seen its beauty. Are there not others who live next door to Beauty, not knowing that she is at home?

The microscope has shown us enough beauty in the moss on a weather-beaten fence, or in the green scum of the algæ on a pond to make Hogarth and Turner laugh aloud with delight and wonder. Such beauty is not only for the few, but for the many, who may sight her footsteps everywhere.

Beauty awakens in us a delightsome sense of wonder and harmony. The form of beauty may be old, but the 


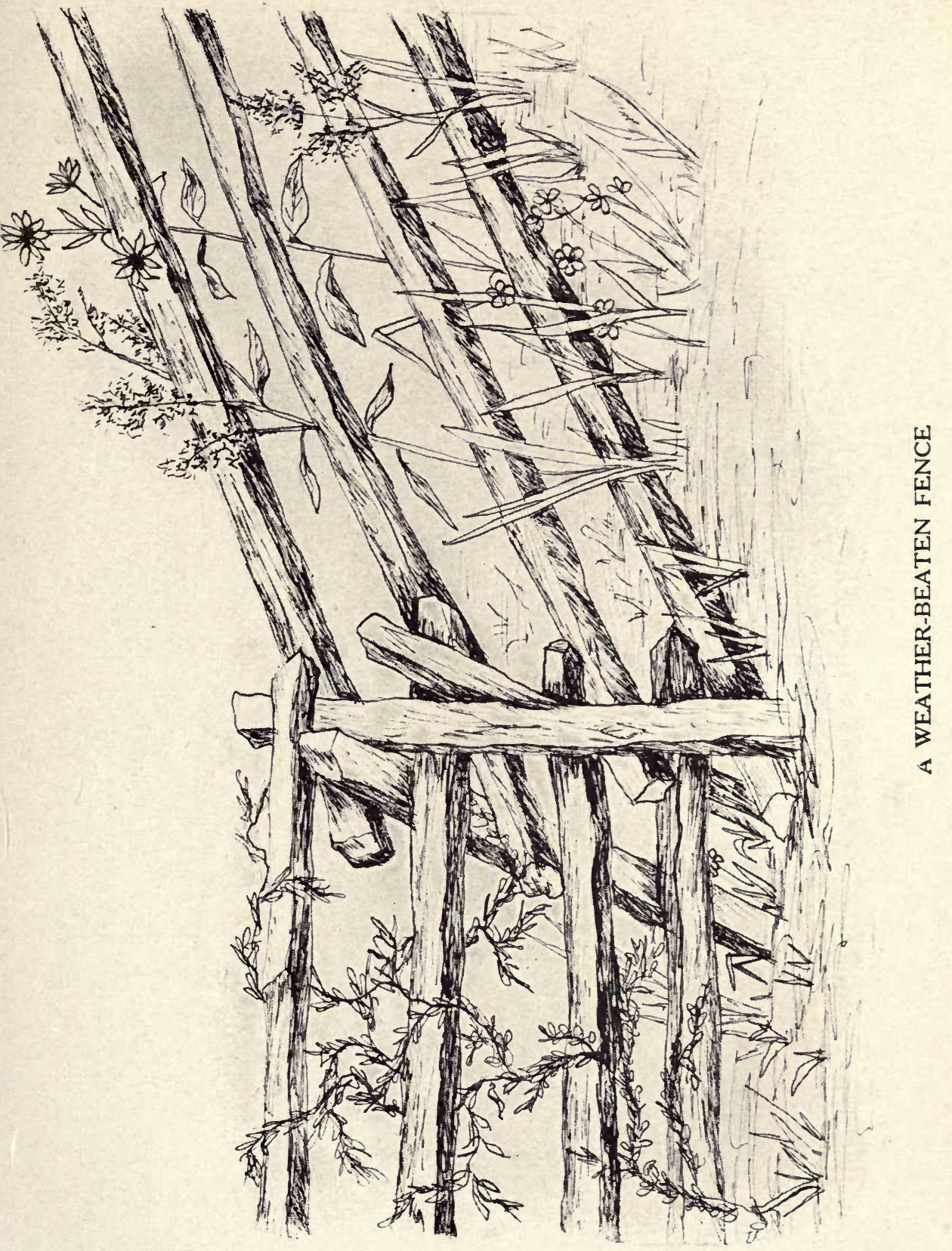





\section{A Word About Beauty}

spirit of beauty is always fresh. Beauty's great essentials never grow stale. Nothing that God has made is structurally ugly-His touch always beautifies, whether in landscape or in life.

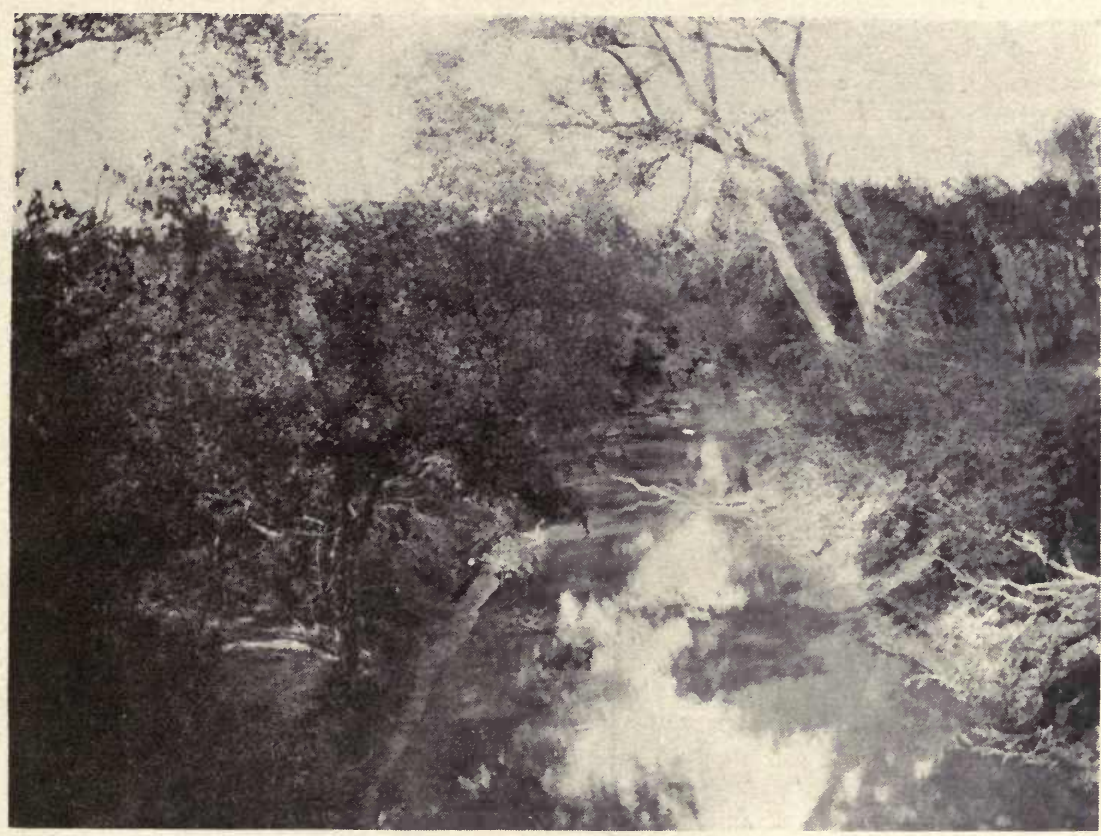

The great Hugo said, "The beautiful is as useful as the useful." Work that beautifies is useful. The beautifier is a blessing anywhere. Every soul is meant to be a sensitized plate to catch the beauty of God as it drifts across the world. It is worth long vigils in day or night to discover. Those who knew John Ruskin tell us that he asked the people around his house to call him from his study by day or from his sleep by night to witness any unusual spectacle in the clouds or the sky. Always, in daylight or dark, beauty is doing something that is worth the seeing. 


\section{Meadow and Mountain}

I was led from boyhood up to man among the sweet, wild meadows of the prairies. I have walked among the foothills of the mountains. I have climbed up the giant shoulders of the Sierras and the great Rockies. On an August morning I have kissed the frost from wild strawberry leaves at the edge of the Paragoy Meadows up in the Sierra Mountains, and have strolled with gladsome boys through the bewildering beauty of wild-flowers abloom in mountain gardens. And in it all there was too much gladness to hold in one human heart; therefore in the pages that follow I have sought, with the aid of artist and printer, to show to all whose eyes shall look on this book some glimpses, at least, of the glorious sights my own glad eyes have seen "In the Beauty of Meadow and Mountain."

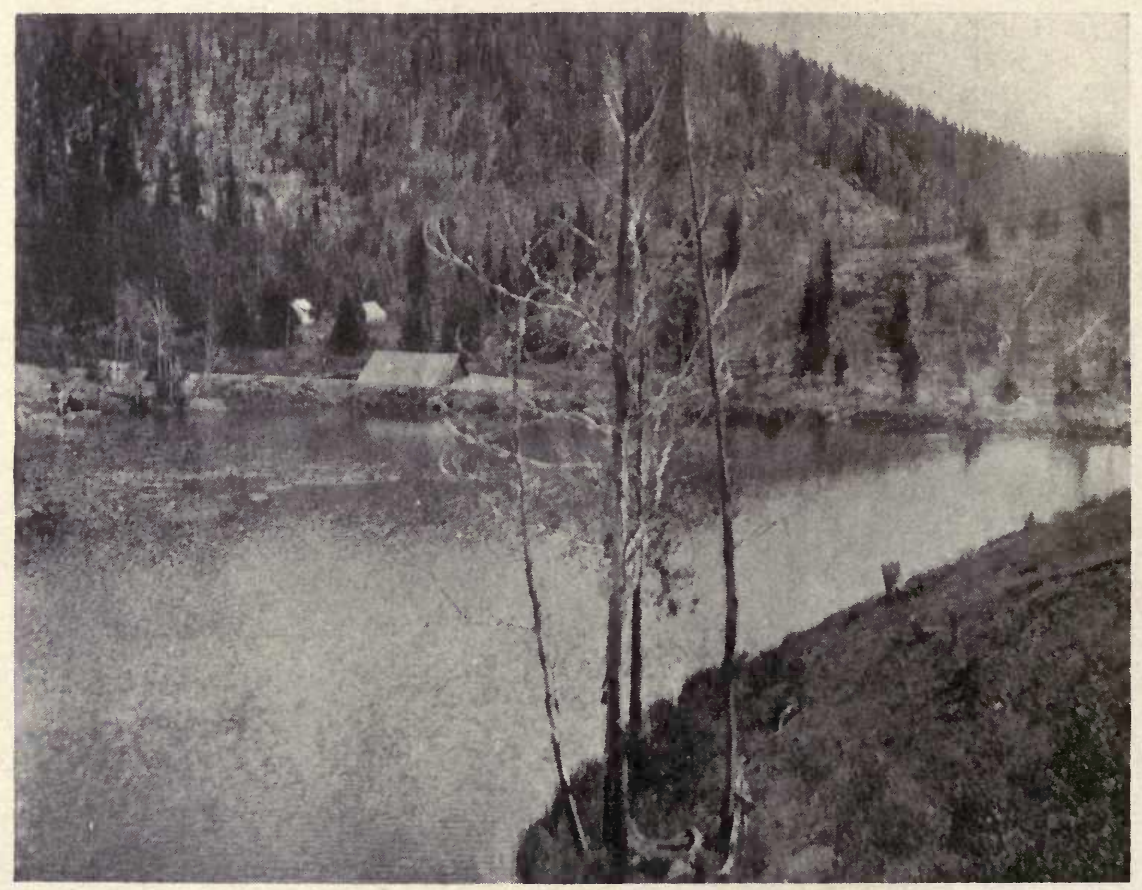



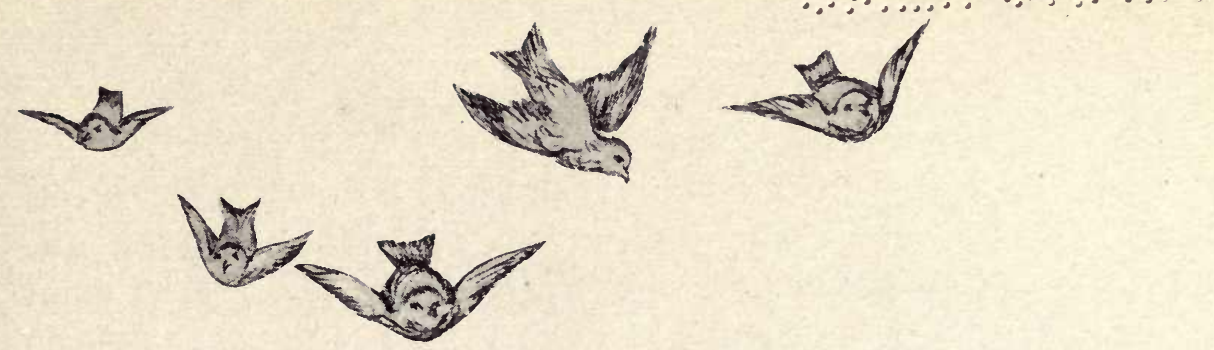

\section{PRAIRIE MEADOWS}
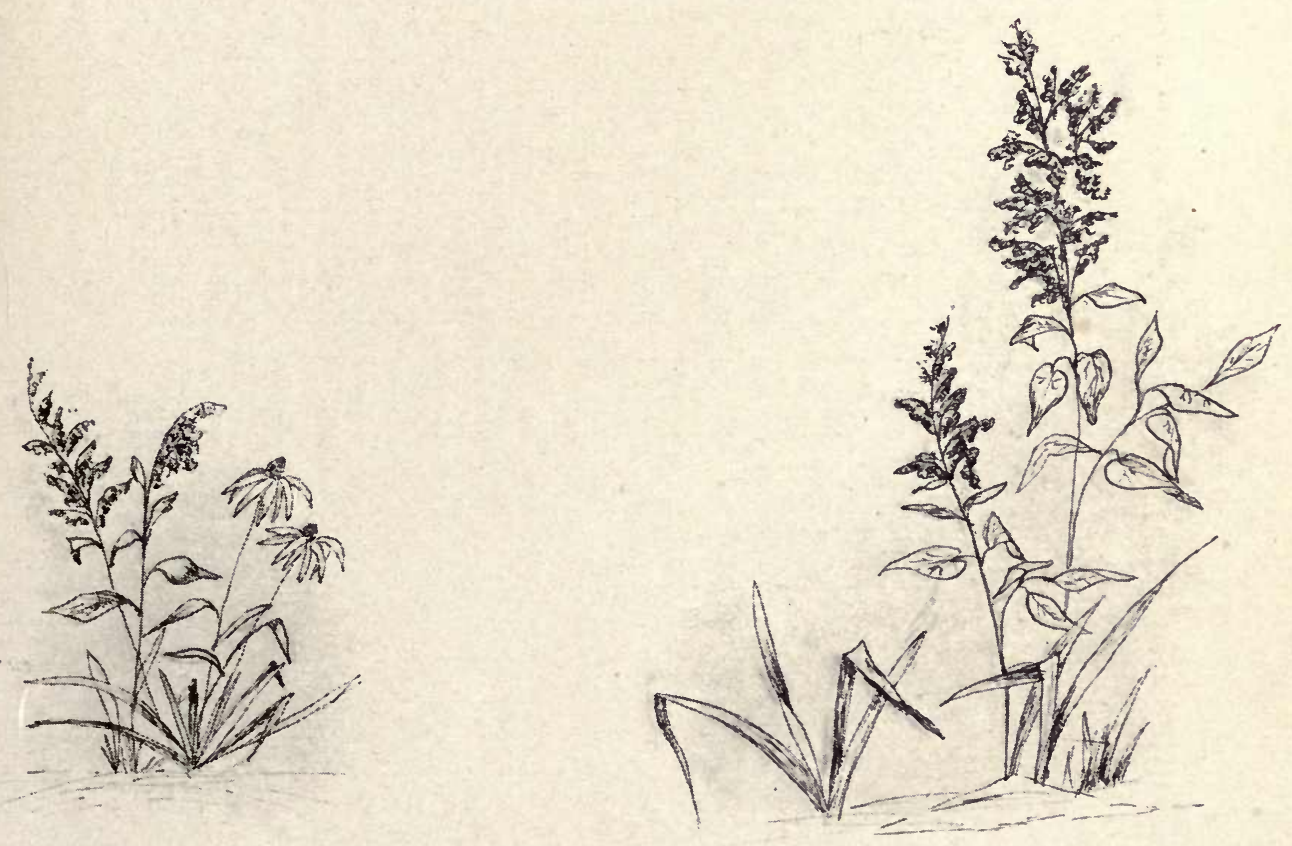
$\therefore$ 
$\because \because \vdots \quad \because \vdots 0 \vdots \vdots \vdots \vdots$

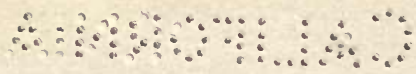




\section{PRAIRIE MEADOWS}

DiD you never go out on the meadows in the May-time? Have you snuffed the city's smoke for a half-century? Then come with me on this May-day and you will find a new delight. The shining feet of day have danced away the darkness and the dew. Balm is on the morning's breath, and all the range is now aglow with the glimmer of the

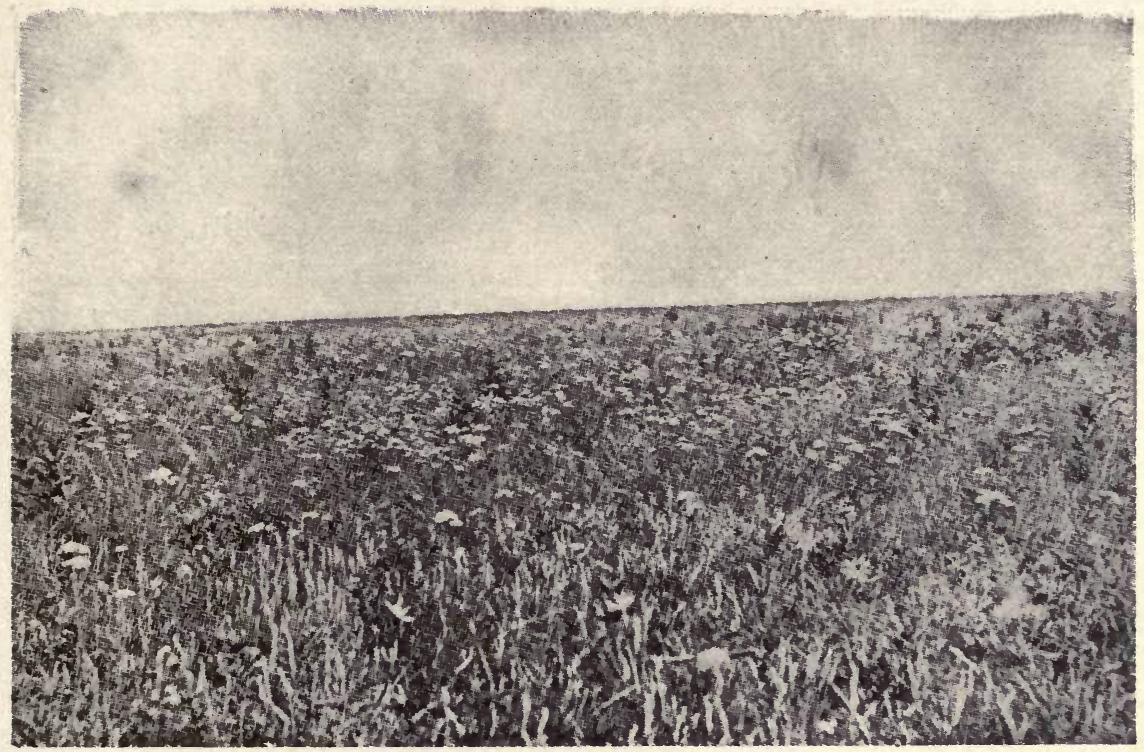

MEADOW BLOOM

grass. You feel in every pulse the poesy of the prairie meadows, and know for once that all "The Pipes of Pan" were but a mythic dream. Uncage the boys and girls and let them frolic on the wild. The Wind-flower will give them welcome and the Star-grass will greet their gladness on this day of May-time glee, and you, Old Man, will laugh with them, for you are young again. 


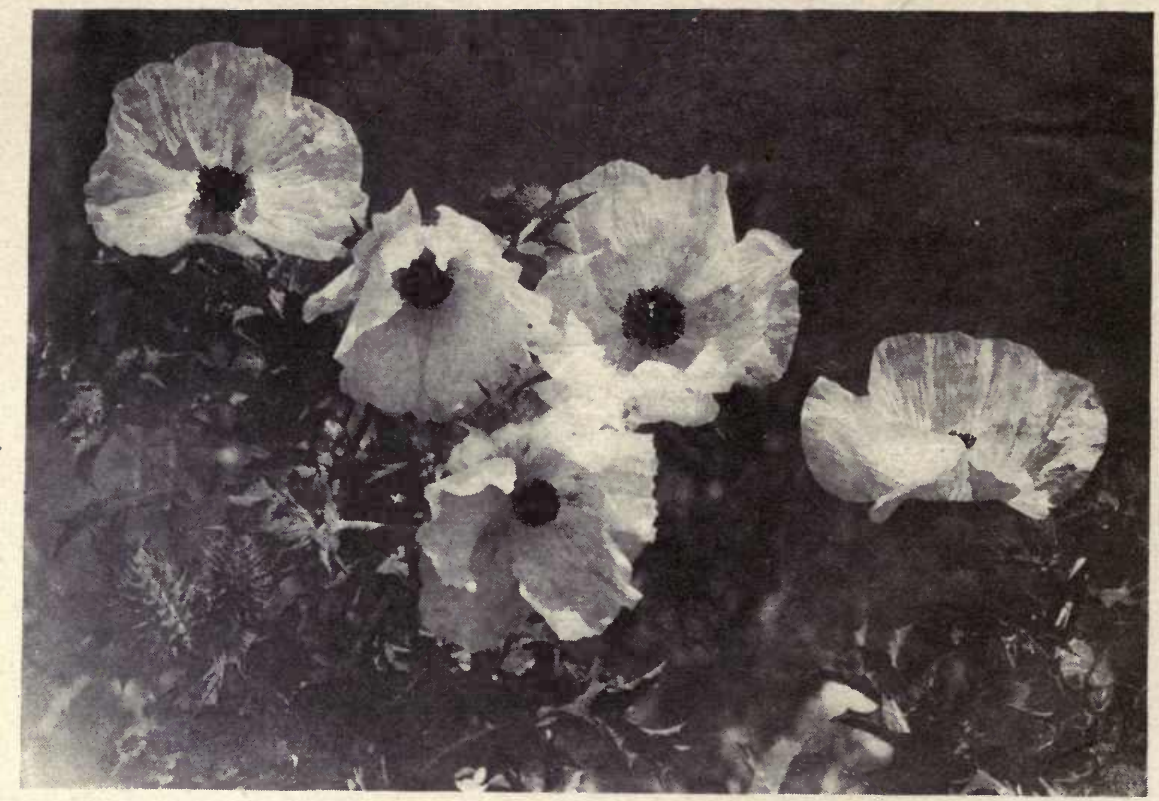

\section{THE WILD THORNY POPPY}

Let Nature pause and rest awhile, since she Hath placed such queenly crown upon thy stem, Like gallant knights bedecked with nodding plumes, And bowing low with courtly grace to give Good heed to all commands of evening winds; When, like a globe of crimson flame, the sun Sinks out of sight within the Western sea, Thou flingest all thy banners out to view; Thy tresses shine to match the stars, when kissed By moon, and dripping with the dew. 


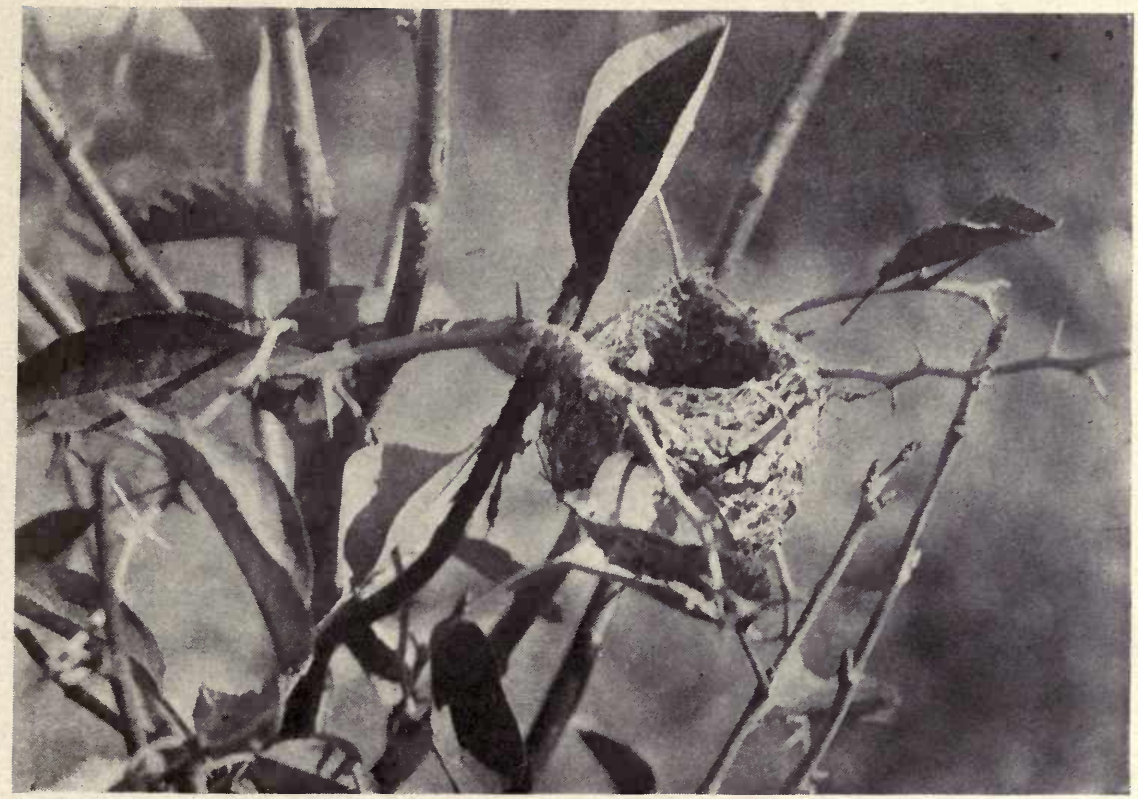

\section{NESTING TIME}

Nesting time is come again,

And love is in the air,

Bluebird, robin, lark, and wren

Are nesting everywhere;

$\mathrm{O}$, love and life are beautiful, $\mathrm{O}$, love and life are sweet;

$\mathrm{O}$, life and love are lyrical,

And love makes life complete! 
$\because \because$

○一

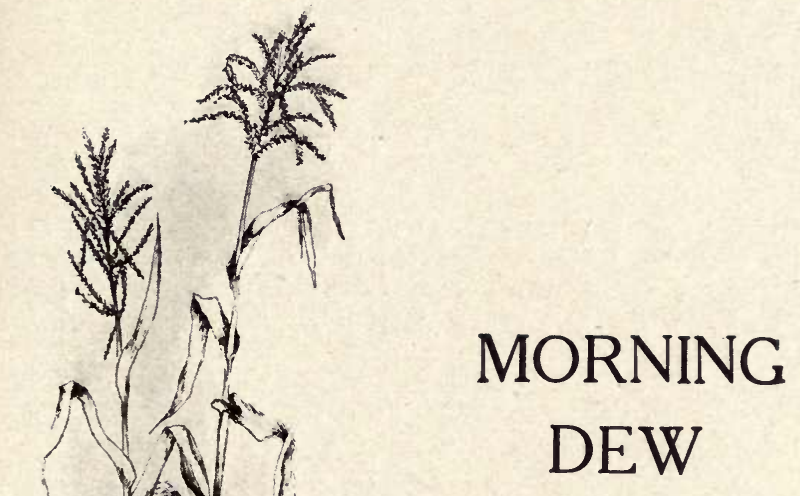


40 and 


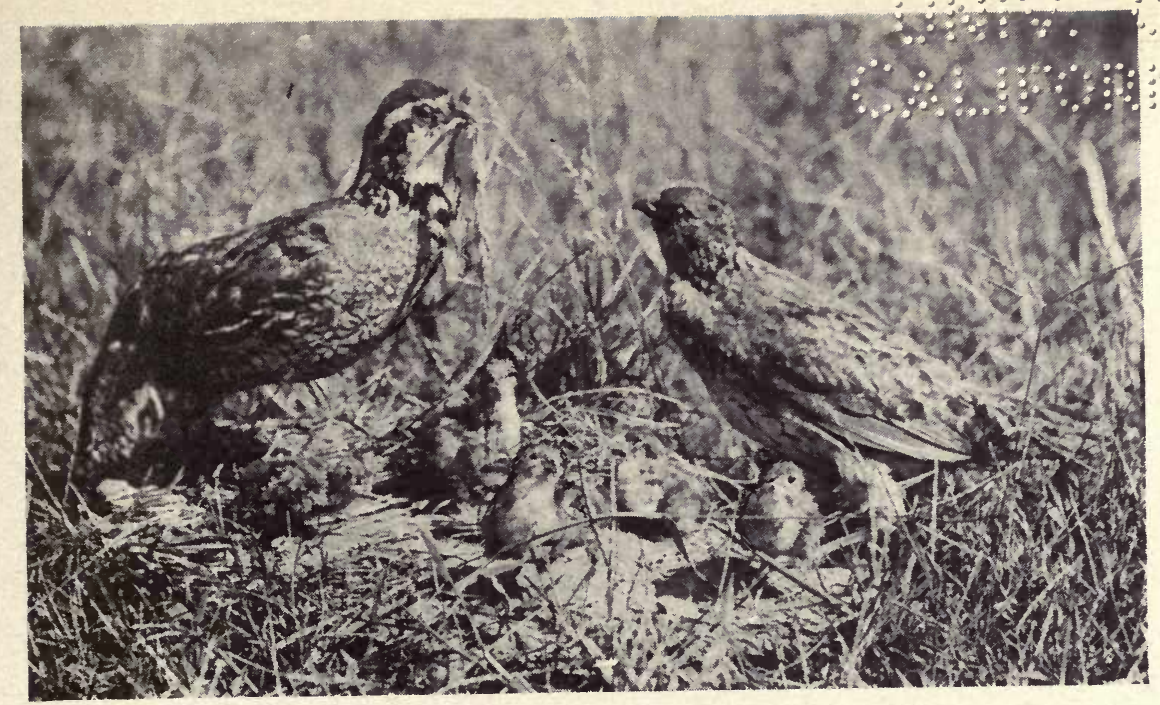

A BROOD OF BOBWHITES

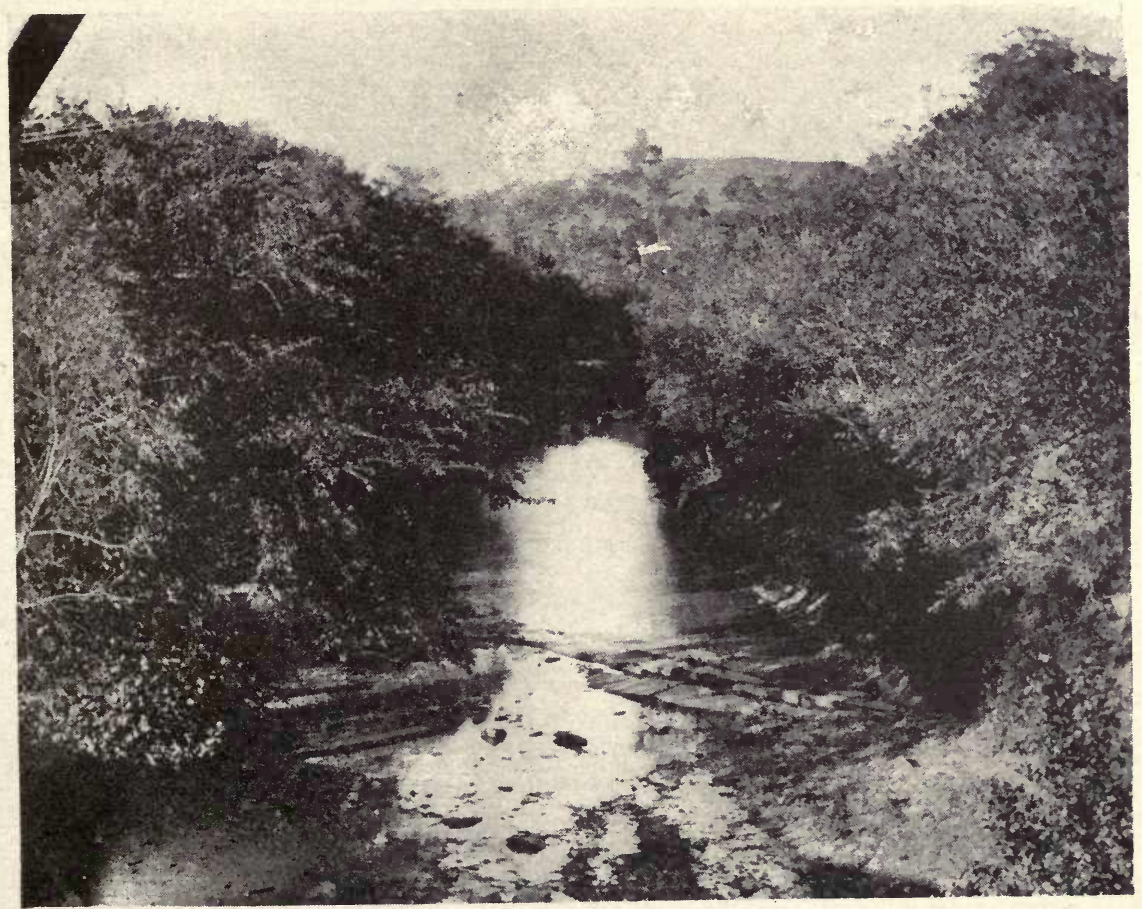

“PLACID LAKES SLEEP IN THE DIMPLES BETWEEN THE 4 ENGIRDLING HILLS" 


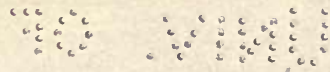

$\therefore 4$ 


\section{MORNING DEW}

WHEN touched by the morning sun, dewdrops in the grass look like fire-flowers. They change each moment as the sun climbs higher and as the lips of light drink away the dark. Every touch of the morning's breath shakes some gleaming globe from blade or leaf. As the morning showers of sunshine fall across the field, ten thousand flaming fairy feet are dancing in the dew. These dewdrops look like little stars that flash and flame and fade away. They look like silver flakes far-fallen from the sky.

What a picture when these shimmering spangles of the dew are seen on a full-flowered flax field! Acres and acres of blue blossoms flashing their tiny torches in the morning light! But the beautiful cups of blue fold up soon after the sunlight falls. No tapestry or finest art can match the delicate tracery of the flax-bloom. If I were printing beauty on finest silk, I would find a model in the blue sky bloom of flax.

"The hillside's dew-pearled." That sight caught Browning's eyes, and we have seen the hillside so. The commonness of such beauty is a hint of the uncommonness of God. He lets fall for us the diamonds of the dew. They fall as copiously on the brown rock's face as they do on the face of the finest flower. They wash the weeds with morning freshness as if the weeds were violets or dandelions or cloverbloom. The ministry of the dew is so gloriously common that we are apt to miss its uncommon glory. It is as if beauty had gone to waste among the weeds. But the weeds have colors and shapes and shadows, and dews among the 


\section{Meadow and Mountain}

shadows-is that not worth the seeing? If it makes somebody glad to see the globes of dew, even among the weeds, is not that gladness good?

Have you seen the dew on the corn leaves-little lakes

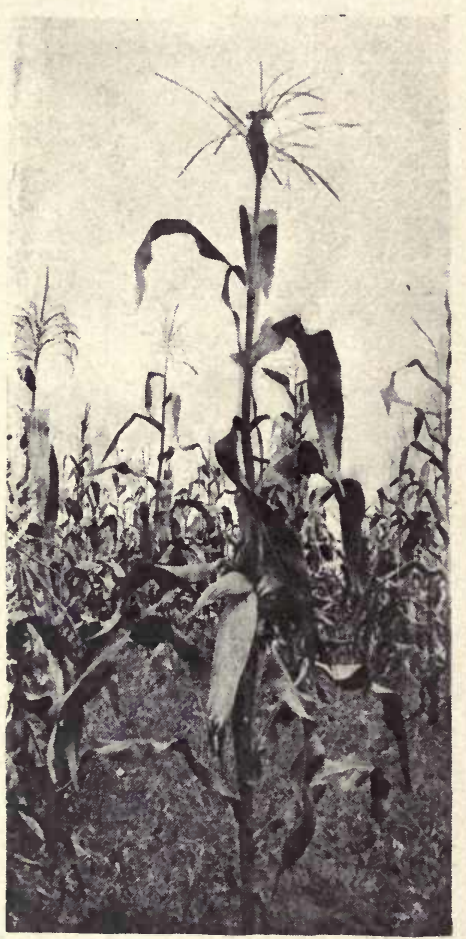
of dew on the corn leaves? Then have you seen the thirsty birds drink-drink dew from the corn leaves on a summer morning? The ministry of freshness is in the dew, the ministry of hope is in the dew, the ministry of health is in the dew, the ministry of life and love - the sweet ministry of God is in the dew.

I have seen the spider's web all tapestried with dew. Dew does not discriminate between a spider's web and a ragged robin-rose. Dew would as soon distill on a spider's web as in a morning-glory's cup. But the spider web is full of dew, and the spider web is hanging in the hedge, and the hedge is hung across with the spider's silver curtain; and while it lasts no palace curtain, woven of the finest lace, could be more beautiful. You shall surely see, if you shall look, that the curtains in the hedge are as exquisite as the curtains in the house.

Many a time I have washed the soil from a boy's brown feet in the dripping dews among the grass. Would that a man's heart could be washed as crystal-clean as a boy's brown feet by the dripping dews! But the cleansing dews of 


\section{Morning Dew}

mercy-do they not fall around us everywhere? Dews on the hillside, dews in the valley, dews among the weeds, dews on the cool morning-face of the rock and dews on the flower's face; dews on the dust, and dews adrip from the apple's bloom-dews of morning, dews of mercy everywhere.

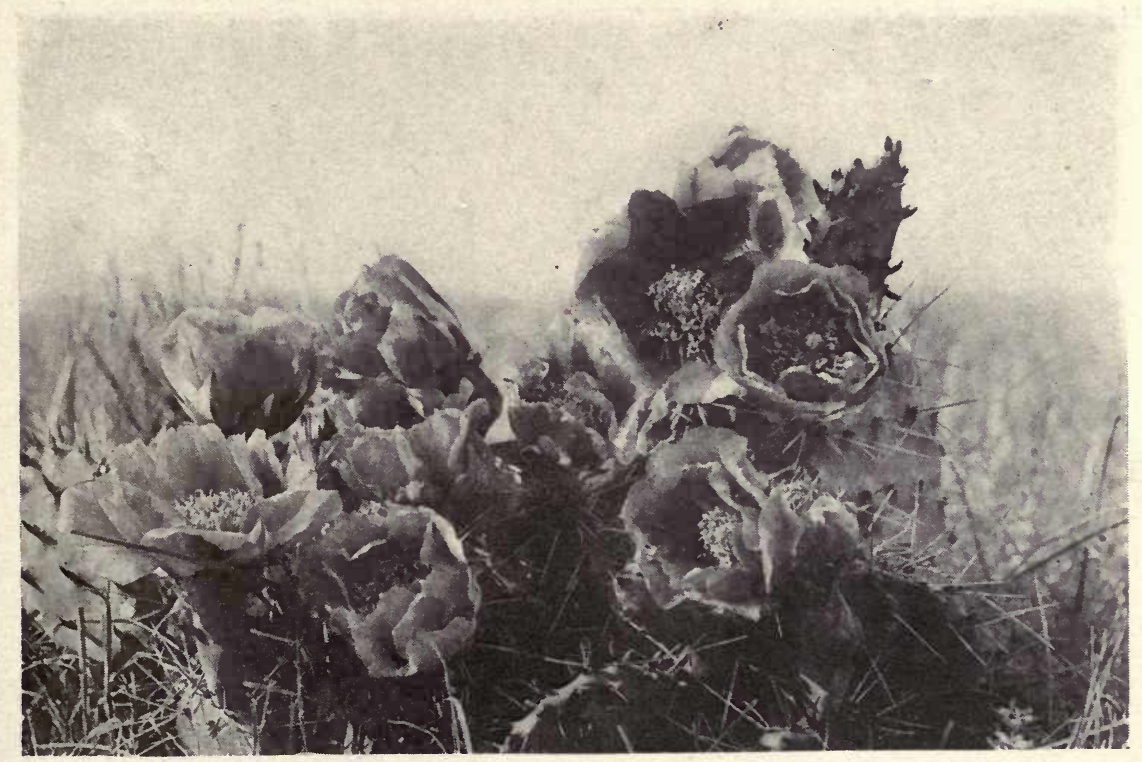

CACTUS 


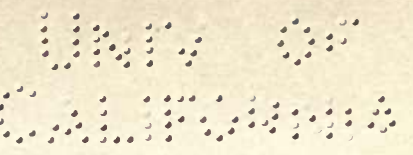

\section{A PARABLE OF} THE TRAIL
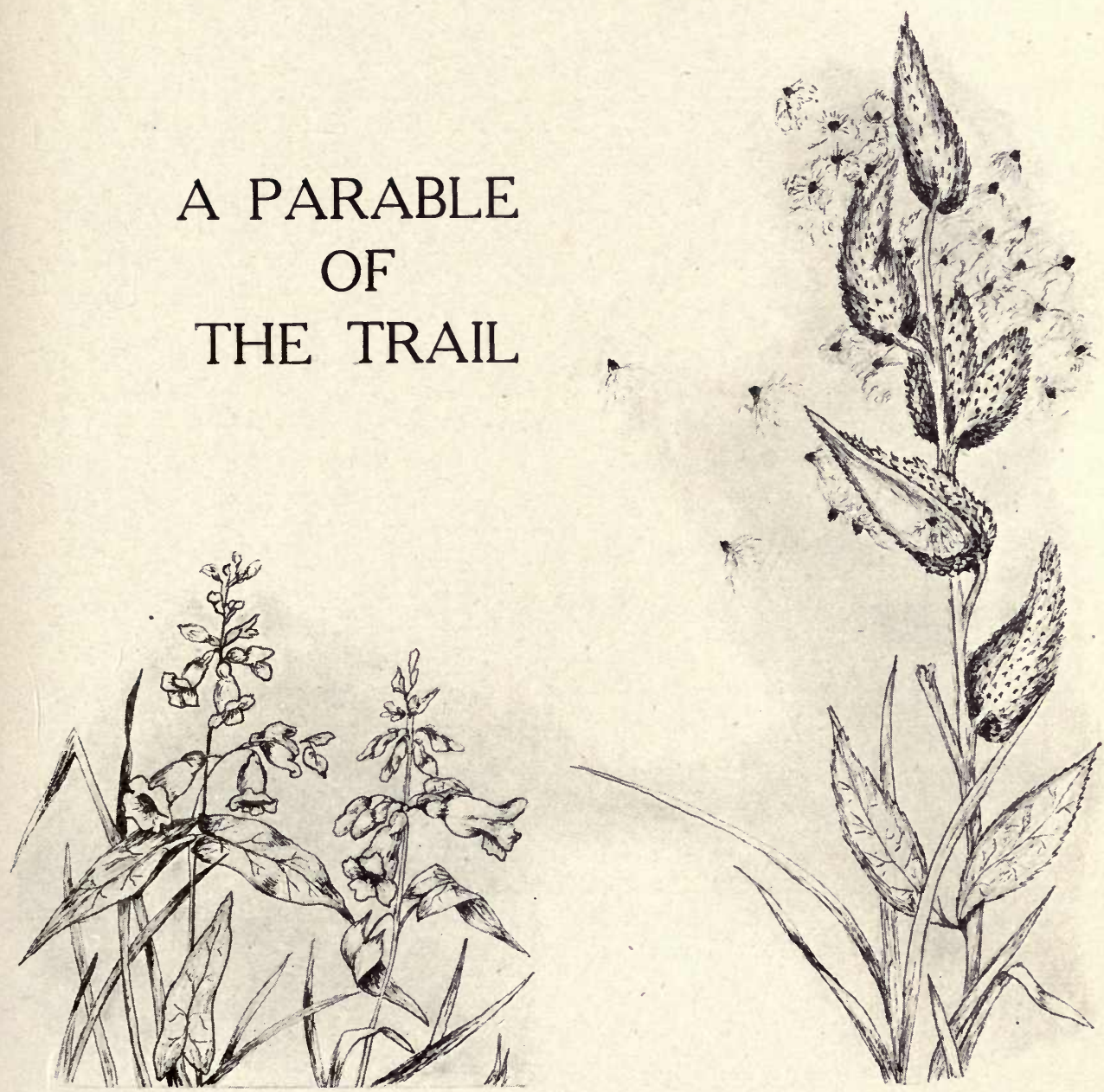



$$
\begin{aligned}
& \vdots y_{0}
\end{aligned}
$$

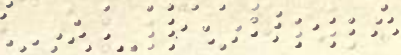

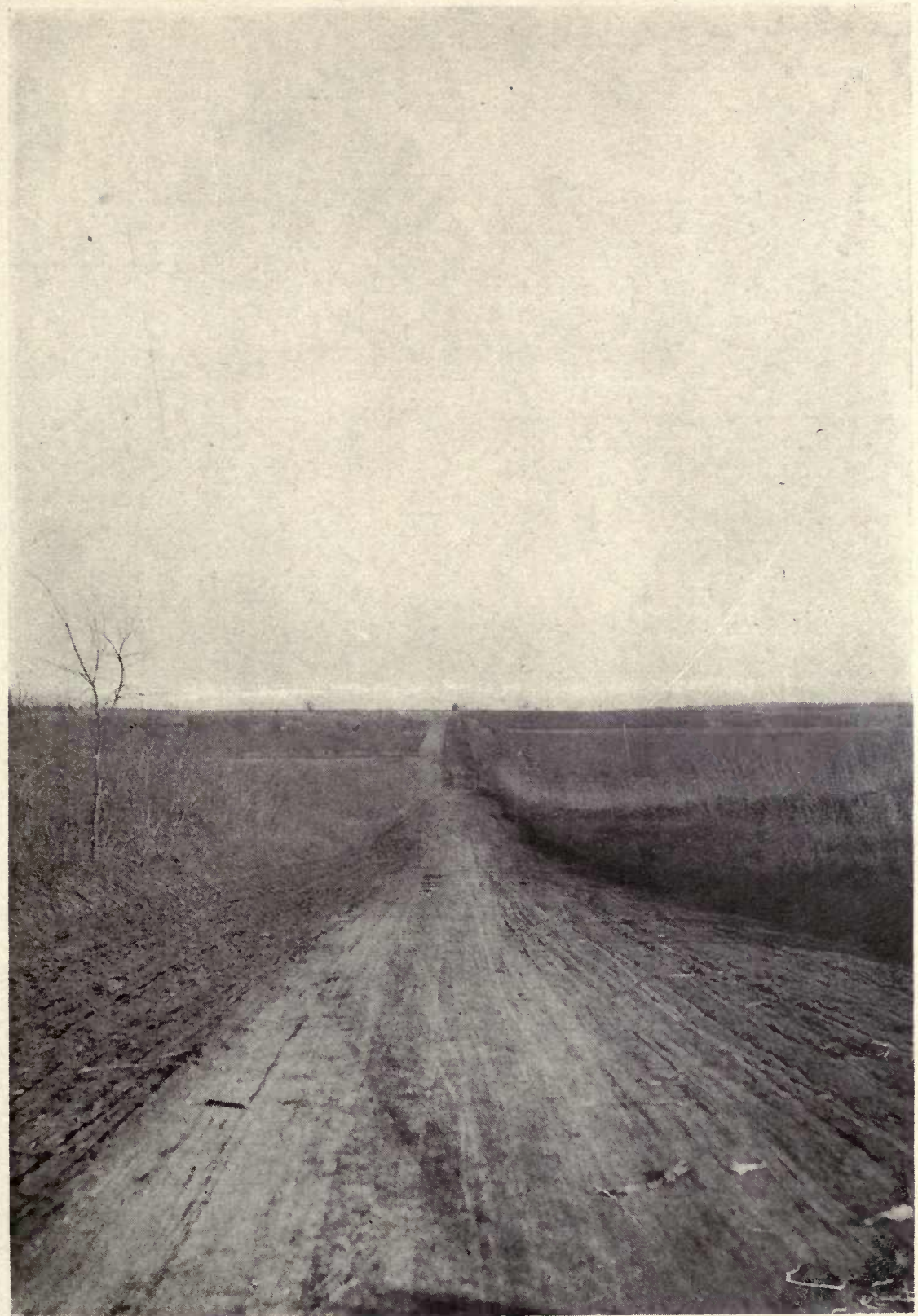

"THE SLUMBERING TRAIL" 


$$
\begin{aligned}
& \because \because \because \quad \because \div 30^{\circ} \vdots \vdots
\end{aligned}
$$

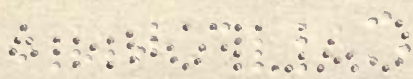




\section{A PARABLE OF THE TRAIL}

THE trail stretched away for many miles. Through all kinds of weather it stayed in its appointed place. Its aim was to be of greatest use where it was. It had no desire to be a trolley-wire, though that would give it a chance to feel the lightning's thrill. It cared not to be a railway-track, though that would afford an opportunity to visit the greatest cities, and to conduct thither the wealthy folk of the land. The trail was content to be where it was and what it was,

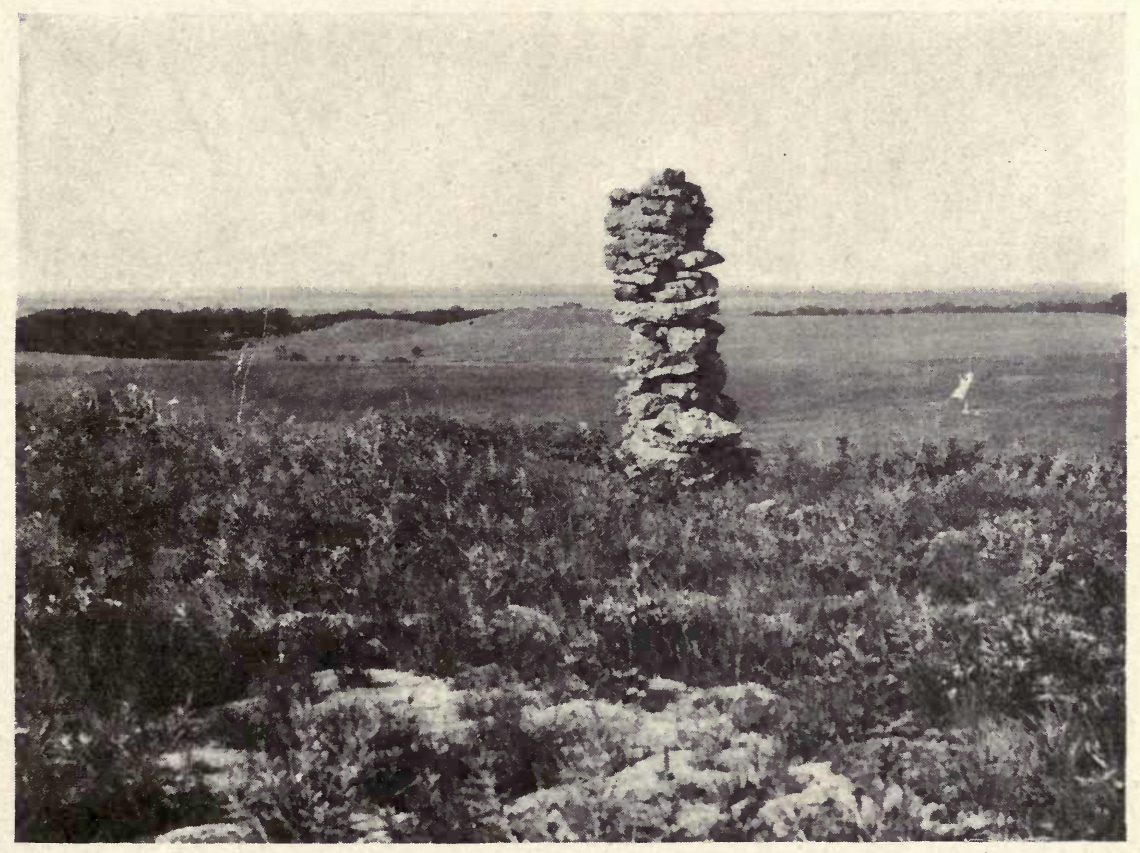

THE RANCHMAN'S LONELY LANDMARK 


\section{Meadow and Mountain}

content to be trodden on by any traveler, if so it could lead to help and happiness.

Hundreds of "prairie-schooners" rolled their wheels along the patient trail, cut-

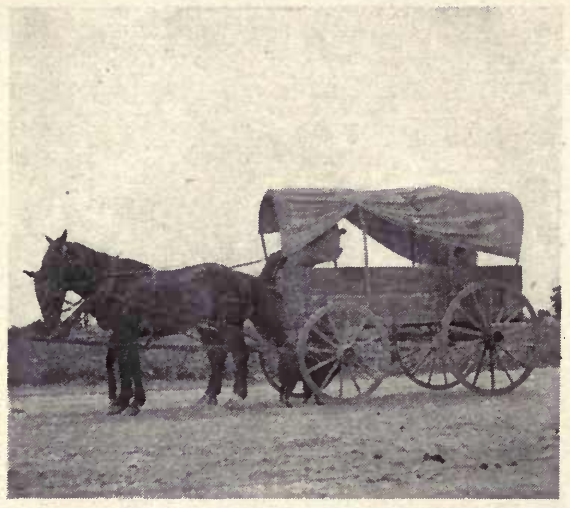

PRAIRIE SCHOONER ting deep scars in its submissive bosom. Thousands of cattle drifted over the range, leaving innumerable hoof-wounds in the winding way. But all the days and nights the trail lay silent and uncomplaining under the whirling wheels and clattering hoofs. Trailers found fault with the trail, sometimes, because it varied from the straight line. The critics forgot their own crookedness. Could they have seen farther, they would have known that they were wrong and the trail was right, for, hiding behind a waving wilderness of bluestem, lay a deep and impassable cañon. To conduct the caravan safely, the trail had varied its course. It made no reply to the chidings of the ranger whose sharp-hoofed herds were cutting uncounted scars in its breast. It led safely on, avoiding the dangerous cañons, and affording a pleasant passageway through the thick-sown cactus and sagebrush, or in curves between trees to the river.

Now and then this ancient path across the prairie was obscured by luxuriant growths of grasses. Bunch-grass, bluestem, the buffalo, and the gramma-grasses hugged its dusty edges. They bent over the deep-cut ruts as if to shield a friend from lacerating hoofs and wearing wheels. 


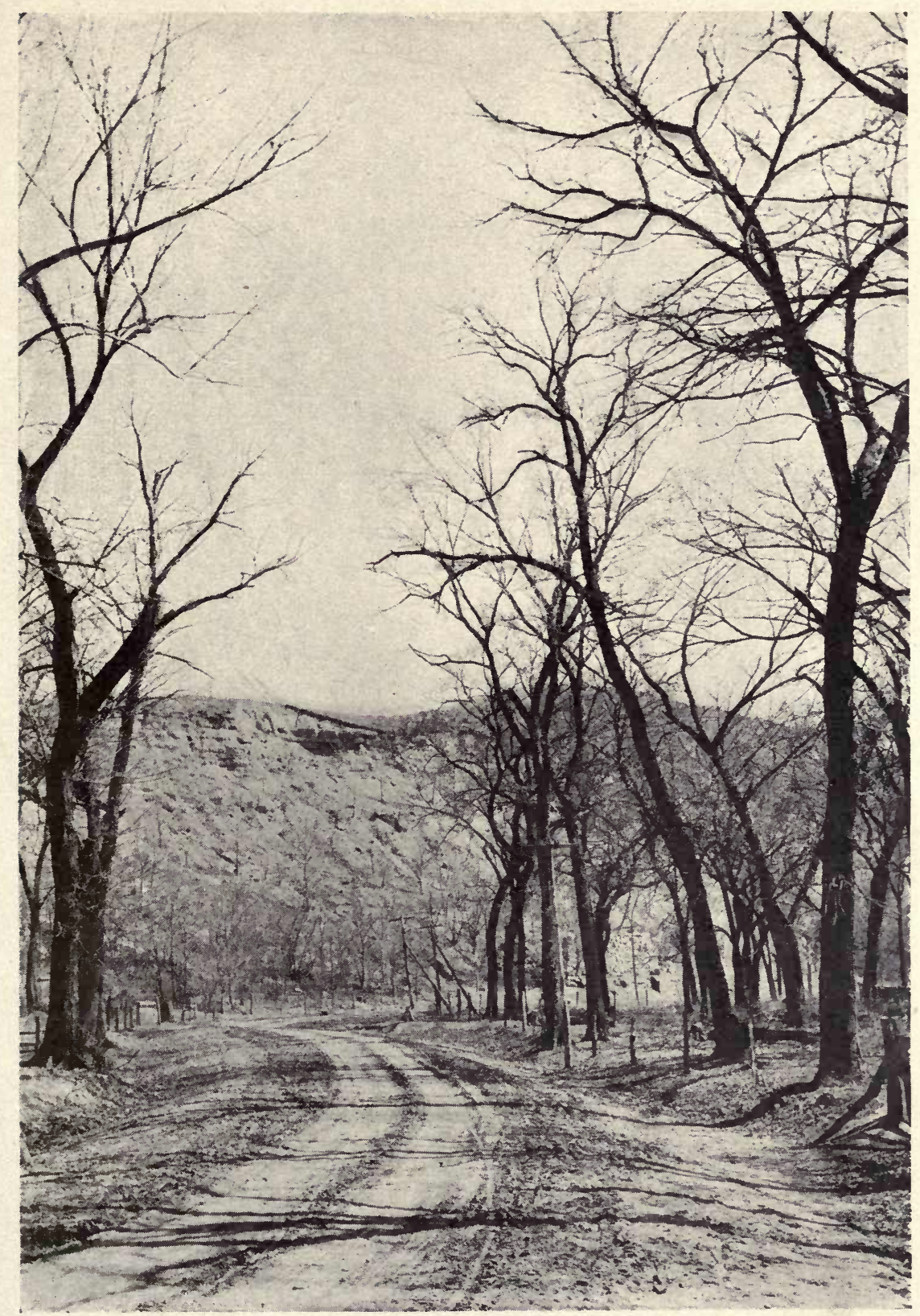

THE ROAD TO THE RIVER 
$\because \vdots \quad \because \because \vdots \vdots \vdots \vdots \vdots$

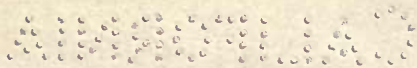




\section{A Parable of the Trail}

Under the blistering heat of the summer's sun they threw on it a calm and cooling shade. And when the freezing breath of the blinding blizzard blew far and wide the frost and snow, these faithful grasses spread their blankets of faded leaves over their old and trusted friend. The trail's destiny was all in the dust, but it was loyal in serving all kinds of travelers. Often the bewildered wayfarer would have wandered, but the trusty trail held him to the right, leading between the breaks where cattle dozed and dreamed.

Once, for many months, a part of the trail was unused by travelers. During these days of loneliness some invisible weaver of the air wove a beautiful robe and silently laid it over the wounds of the slumbering trail. On this cover were pinned in the early days of spring the anemone and the buff baptisia. The warm hands of summer sprinkled it over with blossom-balls of the sensitive rose. And when autumn winds sighed their sorrow over the lonely sleeper under the grass, the sun with his needles of light sewed on the slumberer's mantle goldenrod and many-flowered aster. Many of the smaller furred and feathered folk of the prairie hid them under

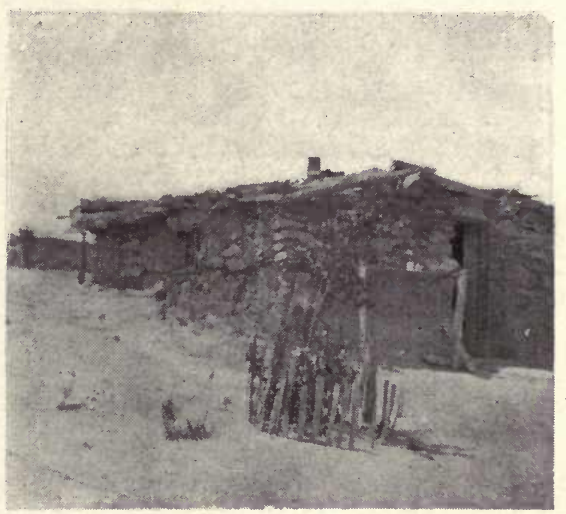

SOD HOUSE this blanket of bloom from the hungry hawk and the swiftfooted hound.

This grass-grown way across the prairie is still untraveled by the feet of men, but it symbols the most unselfish service. 


\section{Meadow and Mountain}

Overgrown with grass, it lies in silence, and far-away has fled its unremembered glory. All of its deeds were done in the dust, but unsleeping watchers looked from the sky. The sun saw in the daytime, and flung his kiss of light. The stars and moon smiled at night, and sifted down their mildest beams. Angels walk with noiseless step across the star-sown field of blue, and softly drop the soothing dews of long, untroubled sleep.

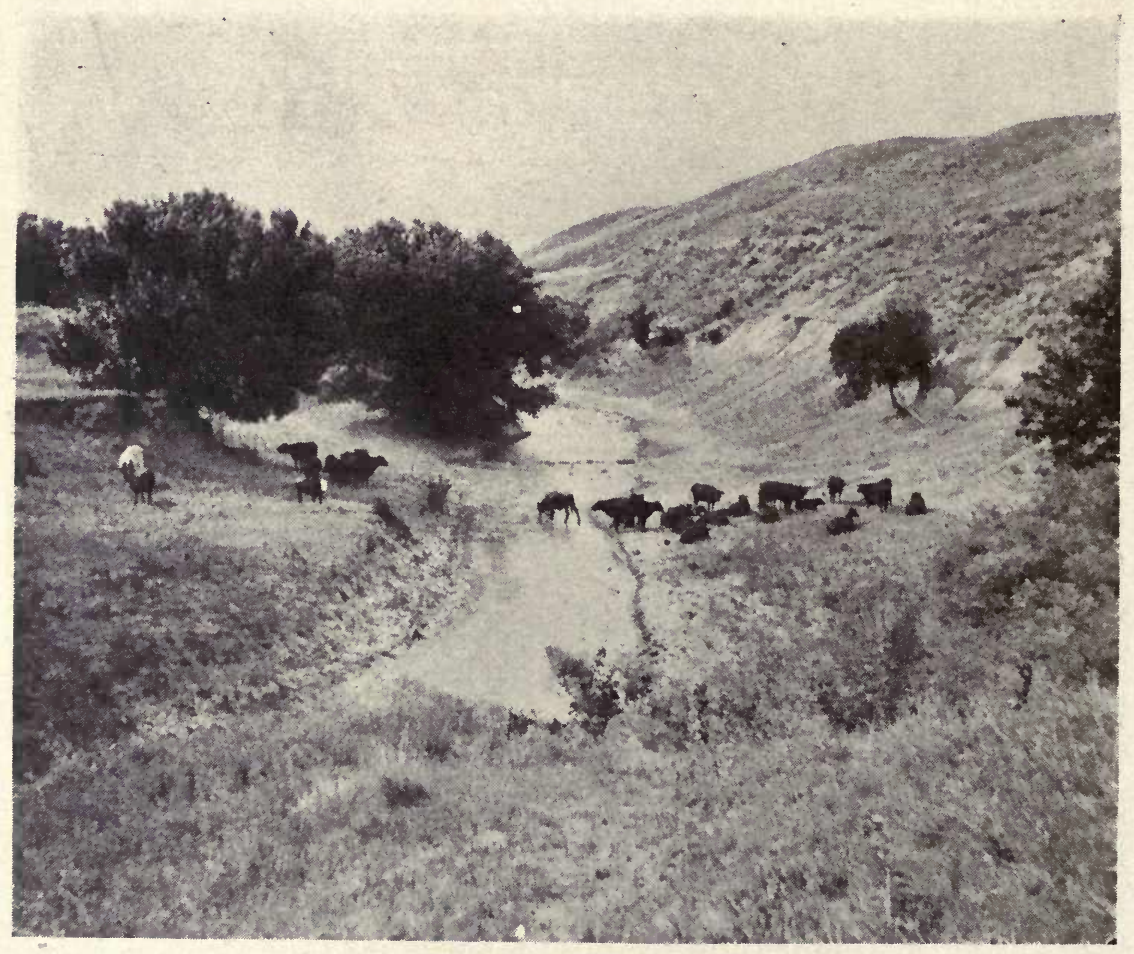

"WHERE CATTLE DOZED AND DREAMED" 


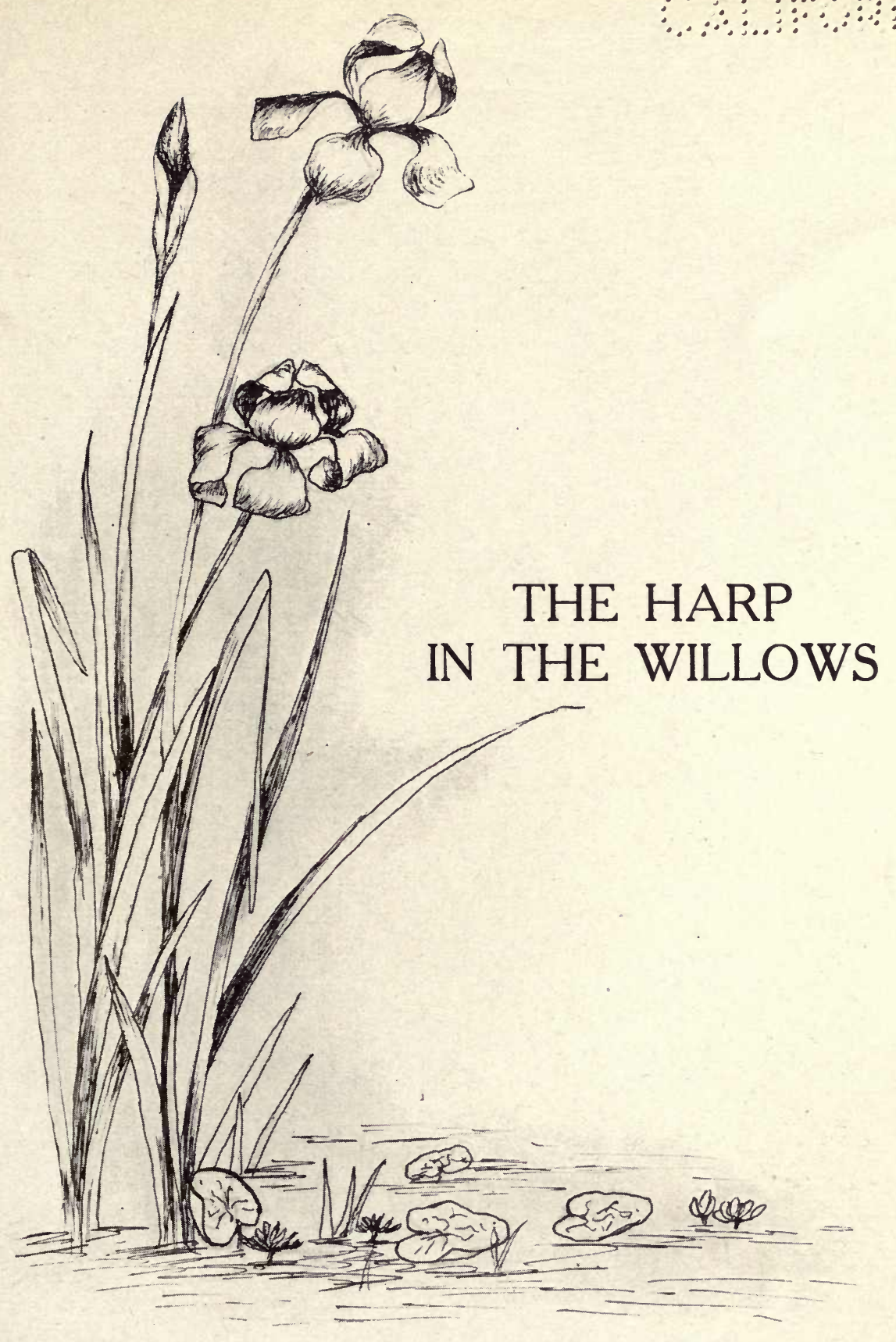




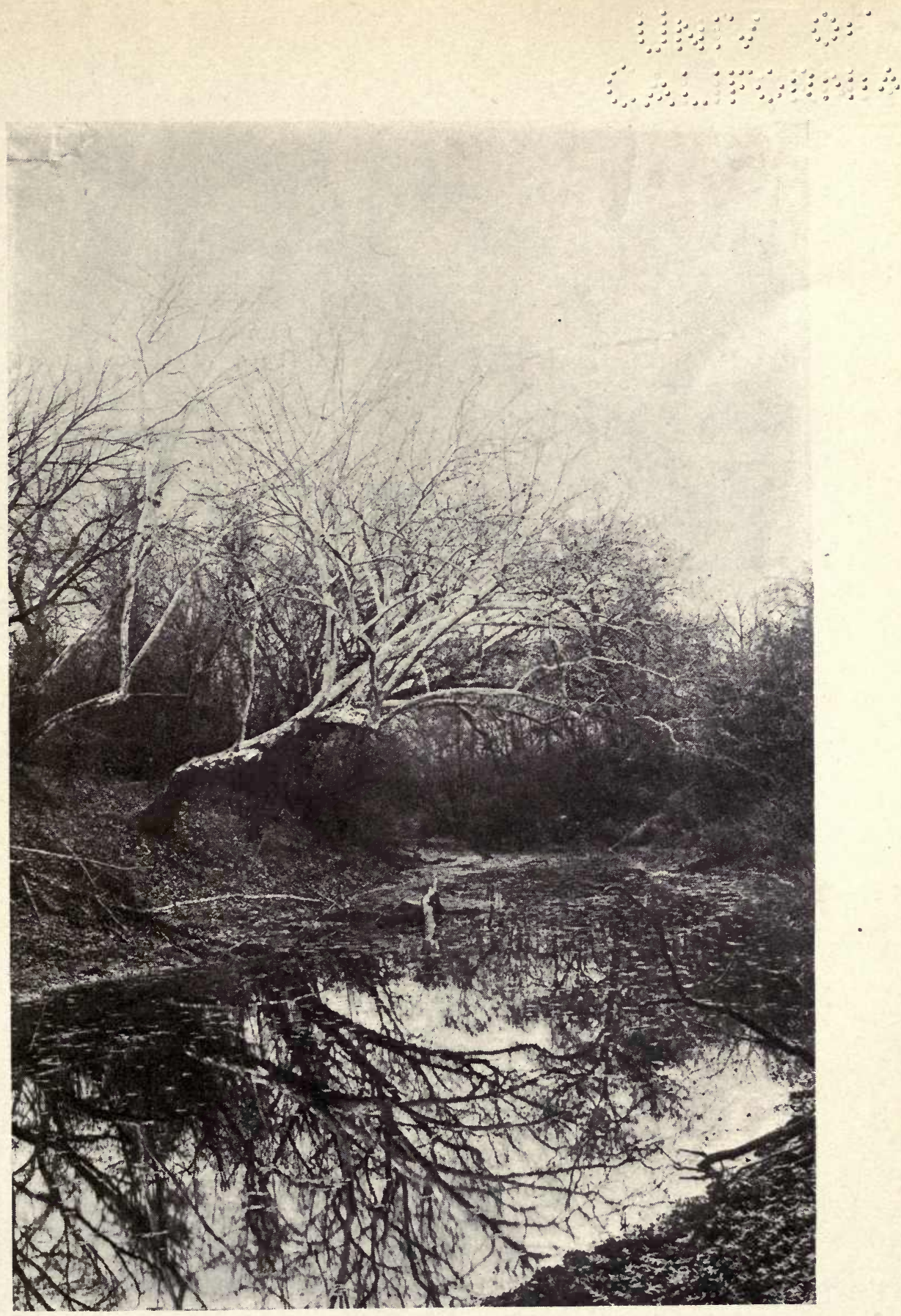

A PLACE TO DREAM 
$\because \vdots \vdots \quad \because \cdots \frac{\ddots}{\because} \vdots \vdots$

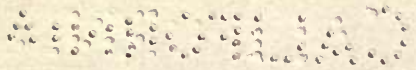




\section{THE HARP IN THE WILLOWS}

A Prairieman sat on a bank between the breaks of the Beaver. The little stream was almost concealed by the willows that grew on its edges. Their yellow arms moved gently under the west wind's breath. When shaken by sudden gusts they shed their leaves like flakes of yellow snow. From many a tangle of vines the foxgrape hung in blue-black clusters. It was a fitting place to sleep and dream. Often when the bodily-eyes sleep, new seeing comes upon the soul. Men often see most with their eyelids closed. The prairieman saw a being of bewitching beauty standing in the willows with a harp at her side. Her shoulders were draped with some snowy fabric, as if it were woven from the yucca's bloom. Her tresses were like black threads that the winds had plucked from the robes of night. Her eyes held the light of summer noons. The motions of her hands were as measured as the movements of music. Her sandals shimmered like shoes of gold. The prairieman waited in wonder to catch the cadence of her words. Or, he thought, mayhap, that she might sweep unwonted strains from that strange harp which she held in her hands. He waited in silent wonder. The harp was wreathed about with grape-leaves, goldenrod, and many-flowered aster. The strings of the harp were not all the same color. Some were white, others red, and some were black. The mysterious stranger swept her hand across the responsive strings. Eagerly the prairieman bent toward the melody. Never before had he been so expectant. As the music flowed over him, every fiber of his 


\section{Meadow and Mountain}

body and every faculty of his mind was tense with rapture. His soul drew toward the player as the sea draws toward the moon in times of tide. The air was atremble with sounds as sweet as the sunlight songs of morning. The music was plaintive. Its tones were full of pleading. Then it came in low, quick sobs. The prairieman noticed that only the white keys had been touched by the player's hand. Then he read across the white strings words which had hitherto been invisible. The words were, "The music of infancy."

After a brief pause the player's hand smote the chords again, and more quickly than before. Still she left untouched the red and black chords. The music broke in gusts like the winds of March. Then it tinkled softly like far-off silver bells. Then it came in frolicsome leaps and with snatches of laughter and song. It was hilarious and made the heart beat high with hope. It recalled to the prairieman his boyhood days and wakened a thousand delightful memories. It was the mirthful music of childhood.

Again for an instant the player paused. Wing to wing two turtle doves flew past. Side by side a robin and his mate sat, feasting on the wild foxgrapes. A meadow-lark sent his trill across the bluestem. Save the lark's note and the swish of the wind-blown grass, silence brooded over the dreamer and player. Then music broke from the harp like the unleashed winds of a storm. It swept every nerve with emotion. The hand of the harper smote now on the scarlet strings. The sonorous strains died away to symphonious whispers. Then they arose like the thunder of the smitten sea. It was the plea of passion voicing itself in the music of love. Then the tones subsided like caressing winds when wooing the prairies to bloom. Sobs issued from the scarlet 


\section{(n)}

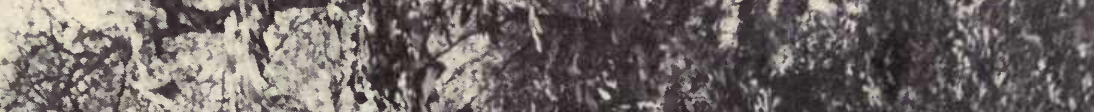

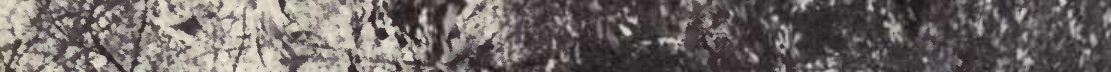

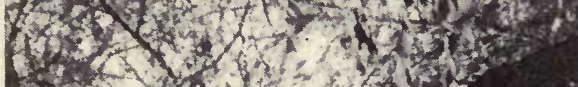

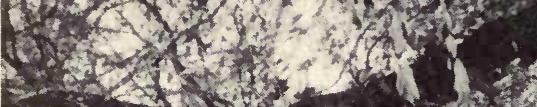

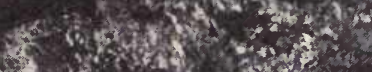
8

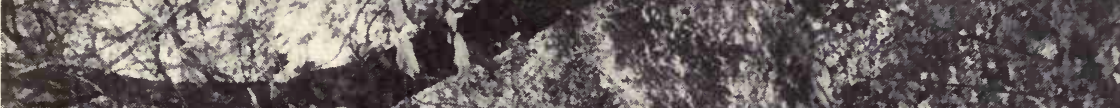

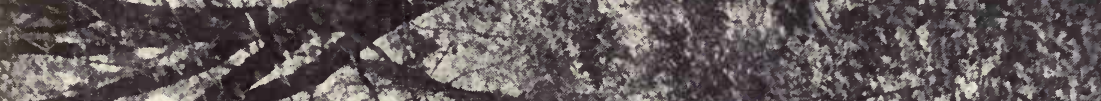

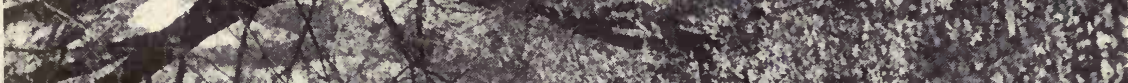
(5)

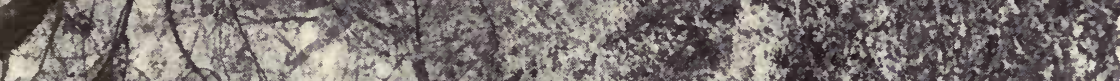

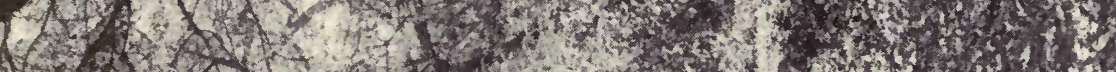

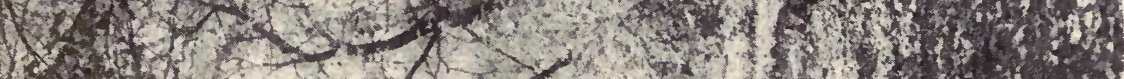

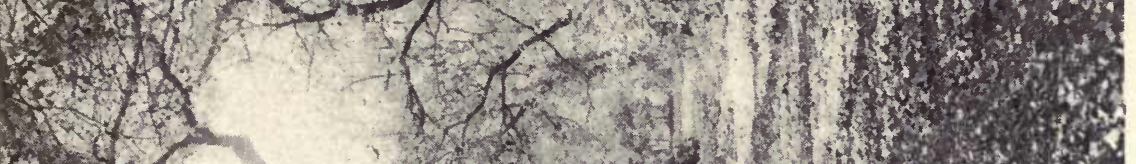

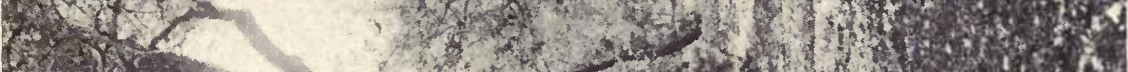
(7x) 30 -

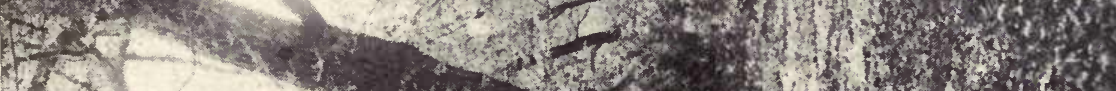

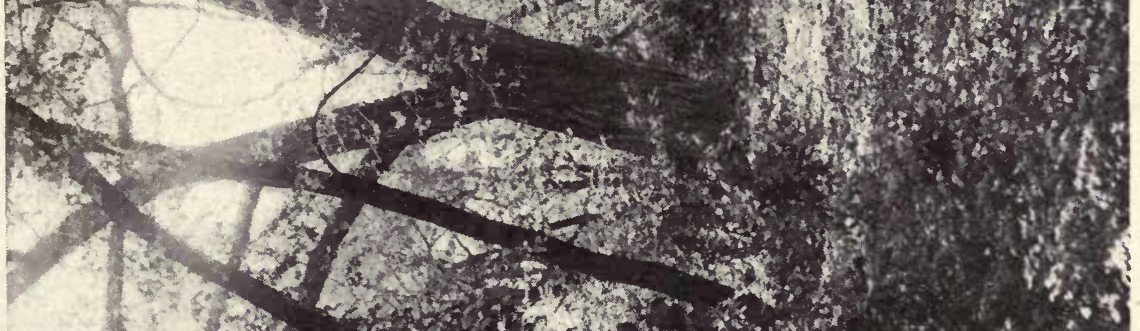

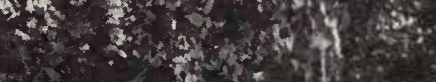
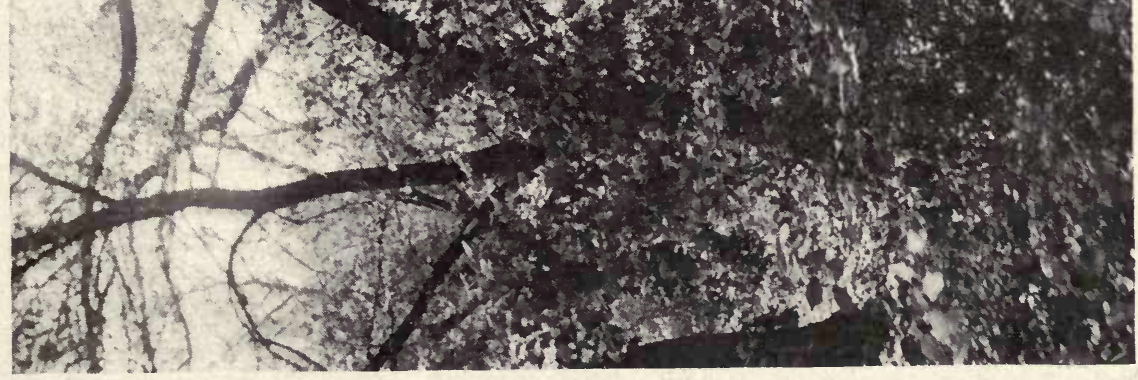


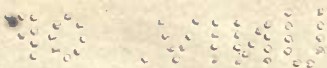

$\therefore$ a 


\section{The Harp in the Willows}

chords as if from the lips of grief, and the music moaned like autumn winds. The soul of life was smiting on the scarlet chords. The harp-strings laughed and wept and hushed again in muffled sounds that fell away to silence and to sleep. Then the prairieman knew that he had listened to the mingled music of youth.

It was the hour of sunset, and shadows were falling among the willows. The harp-strings were as still as the shadows. But the hush was for only a moment. When the player smote the harp again the music sounded loud and long. It was not unlike the undulations of approaching thunder. The starlight sifted through the willows and the moon hung huge and red above the eastern horizon. In the music could now be heard the blare of bugles and the call of captains. Steel was heard to clash on steel. Volley answered volley. Hammers and screaming whistles mingled their deafening din with the buzz of saws, the whirr of wheels, and flying spindles. It was the mighty medley and music of manhood.

Again the prairies are still and the harp is hushed in the willows. The coyote's call breaks the silence with a shrill and fearsome sound. Around the North Star the Dipper swings in stellar splendor. The winds of the night whisper their secrets to the dew-damp grass. And now the music wakes again with the soul of the harper that stands on the willow-fringed bank of the Beaver. Not all the song-birds of the world, nor all the human singers, could match that music now. Wave after wave rolls forth from the black chords. But see! dusk is giving place to dawn. The "black bat, night," will soon be flown. The dawn's kiss has flushed the Orient. Winds of the morning wake and sing. The 


\section{Meadow and Mountain}

melody of the finale is flowing from all the harp-strings now. The deft hand of the harper sweeps through the whole gamut of music and song. It is the music of old age that sings in the night - the Old Age of the good. The harper is life, and the harp is the heart of man.

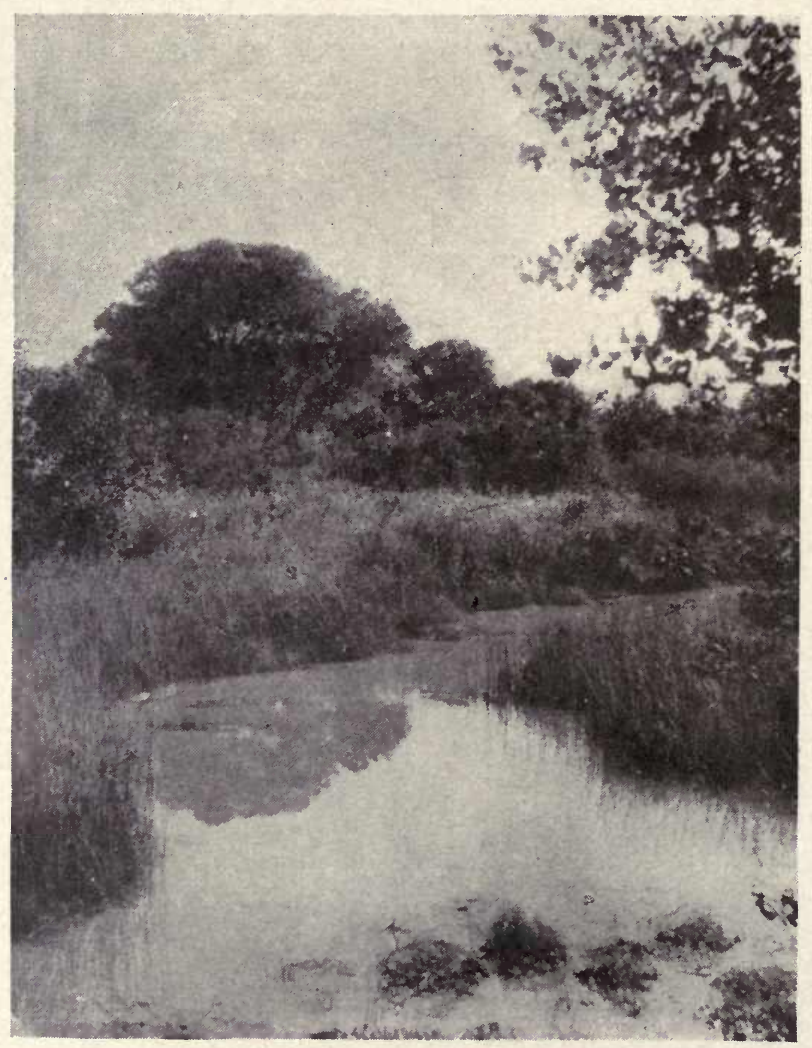




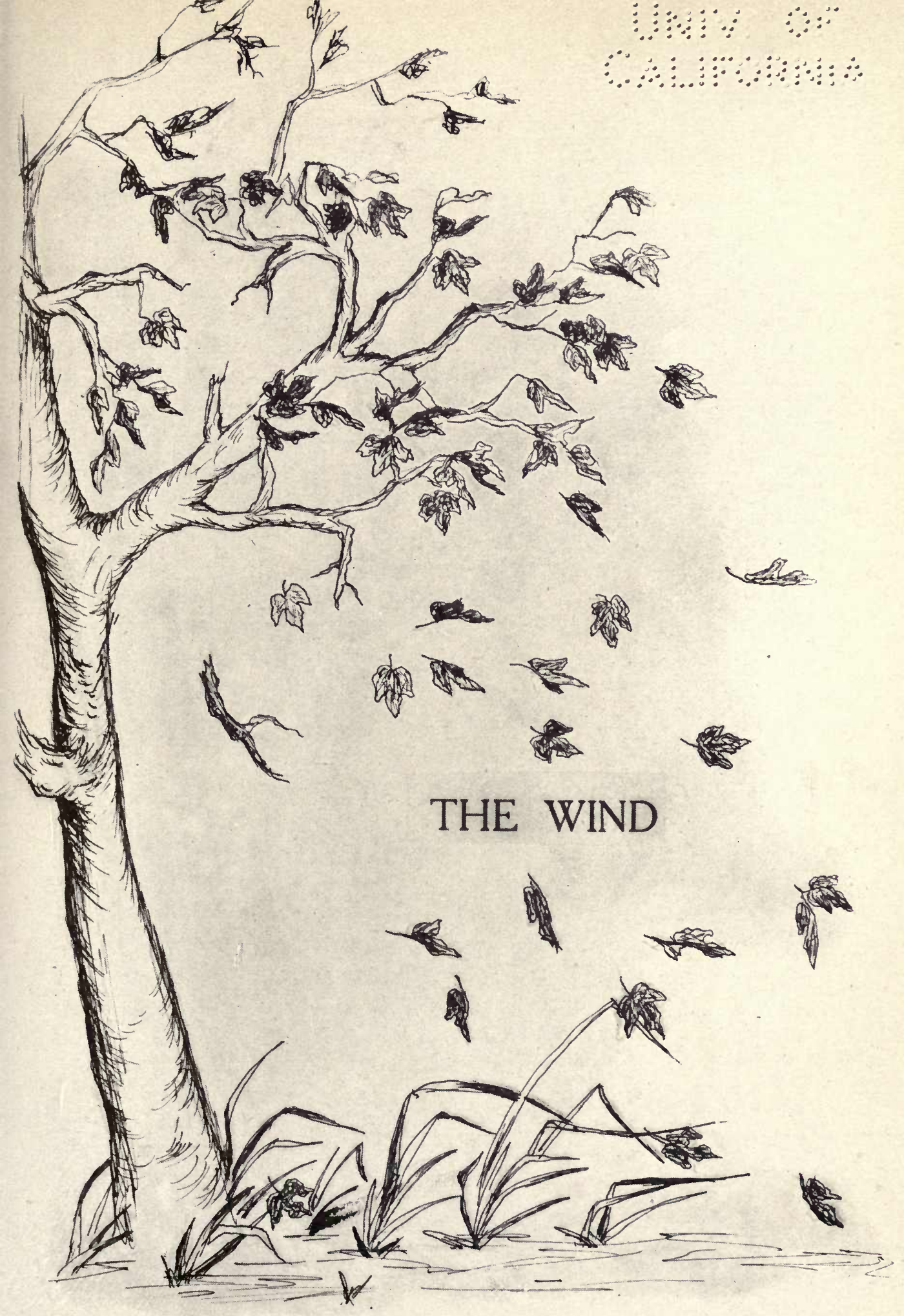



$\because \vdots i \quad \because \vdots i z \vdots \vdots$

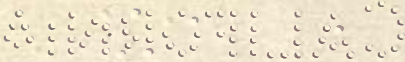




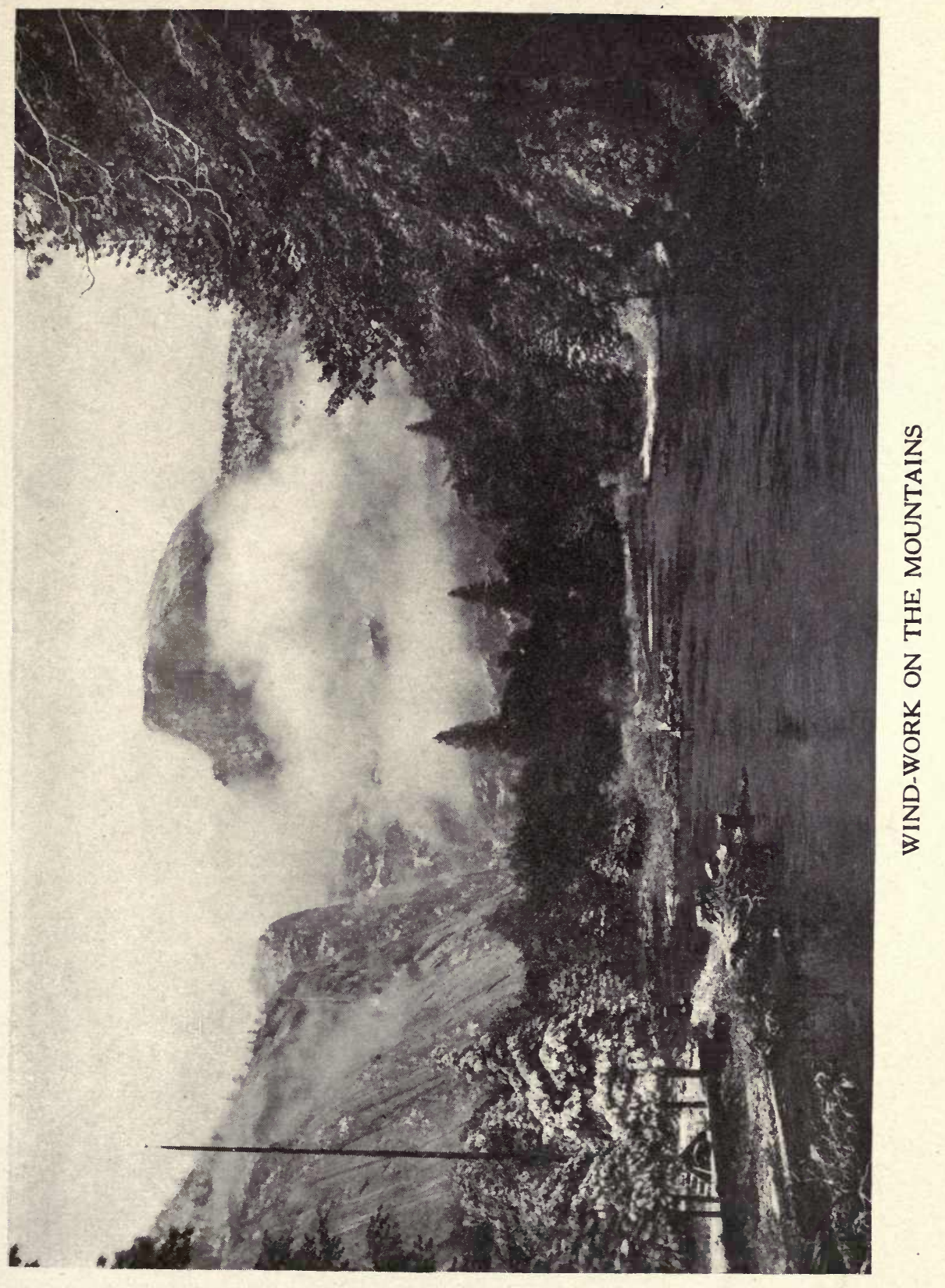


$\because \therefore \quad \because \vdots \vdots$

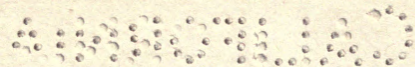




\section{THE WIND}

WhAт a factor in the making of beauty is the wind! Did you ever think of the wind as one of the invisible brushes of the Divine Artist? That is worth thinking about. The wind has its way, and a wondrous way it is. There are melodies in the wind. There are voices in the wind. Alfred Tennyson had an ear fine enough to catch the wind-voices. When only a little lad he said, stretching his hands in the wind, "I hear a voice speaking to me in the wind." To his friends it seemed a fancy then, but to the literary mind of the world to-day it is an outstanding fact in Tennyson's poesy. We know he heard the wind's voice, and how wondrously he set that voice to music! Well, there are many wonderful things about the wind and the works of the wind, when we look or listen or think. The most of us rush past a thousand orchestras and never hear them. We rush through a thousand galleries hung with wondrous artistries and never see them. We miss the teaching of a thousand teachers that stand along the way of life.

But what about the wind? I was saying that the wind is a beautifier. That is no fancy, but fact. Your physicist or geologist would tell you that. Or, would they tell you that? Well, that is what I am trying to tell. For one thing, the wind is sCULPTOR. Have you seen its carvings under the edge of the snow-drift? I have seen an overhanging roof of snow made by the wind - the north wind - and under this snow-roof, on the south side of a snow-wall, a space large enough to shelter a covey of quail, or chickadees, or snow- 


\section{Meadow and Mountain}

birds. To be sure this roof that I am writing about was not Queen Anne style, nor Elizabethan, nor Grecian, nor Romanesque; but it had a style - a style of its own which was a singularly beautiful blending of curves and spirals. There was the most artistic architecture there. It was wind-work of marvelous masonry. The wind is sculptor-that is what I was saying.

Then, again, the wind has so much to do with lights and shadows, with leaves and blossoms. And do not lights and shadows have everything to do with the creation of beauty? The invisible brush of the wind sweeps a cloud across the sun and the shadows fall. Did you ever watch the cloud-shadow creep across a bluegrass meadow? That was the workmanship of the wind! The wind wafted the cloud across the sun. That same wind blew the cloud from the face of the sun. Then came light. Light and shadow, shadow and light - much of that in nature is the work of the wind. And surely you have watched the bending wheat when the wind walked over it. Anything beautiful there? That is sight enough to enrapture all the Ruskins of the world. The walking of the wind over the wheat on my father's farm awakened delights and dreams from whose charms I have not yet escaped. And who would wish to escape the charm of the wind walking on the wheat? I have seen the big black shadow-ball go softly rolling over the wheat-field. Then I knew the winds were out that day playing football with cloud-shadows in the wheat-field. The sun and the wind and the clouds and the green wheat were out playing that day, and God was the great, glad umpire of the game. Friend of mine, sick and tired of the city's fuss, go out awhile and watch that game. But I was talking about the wind! 

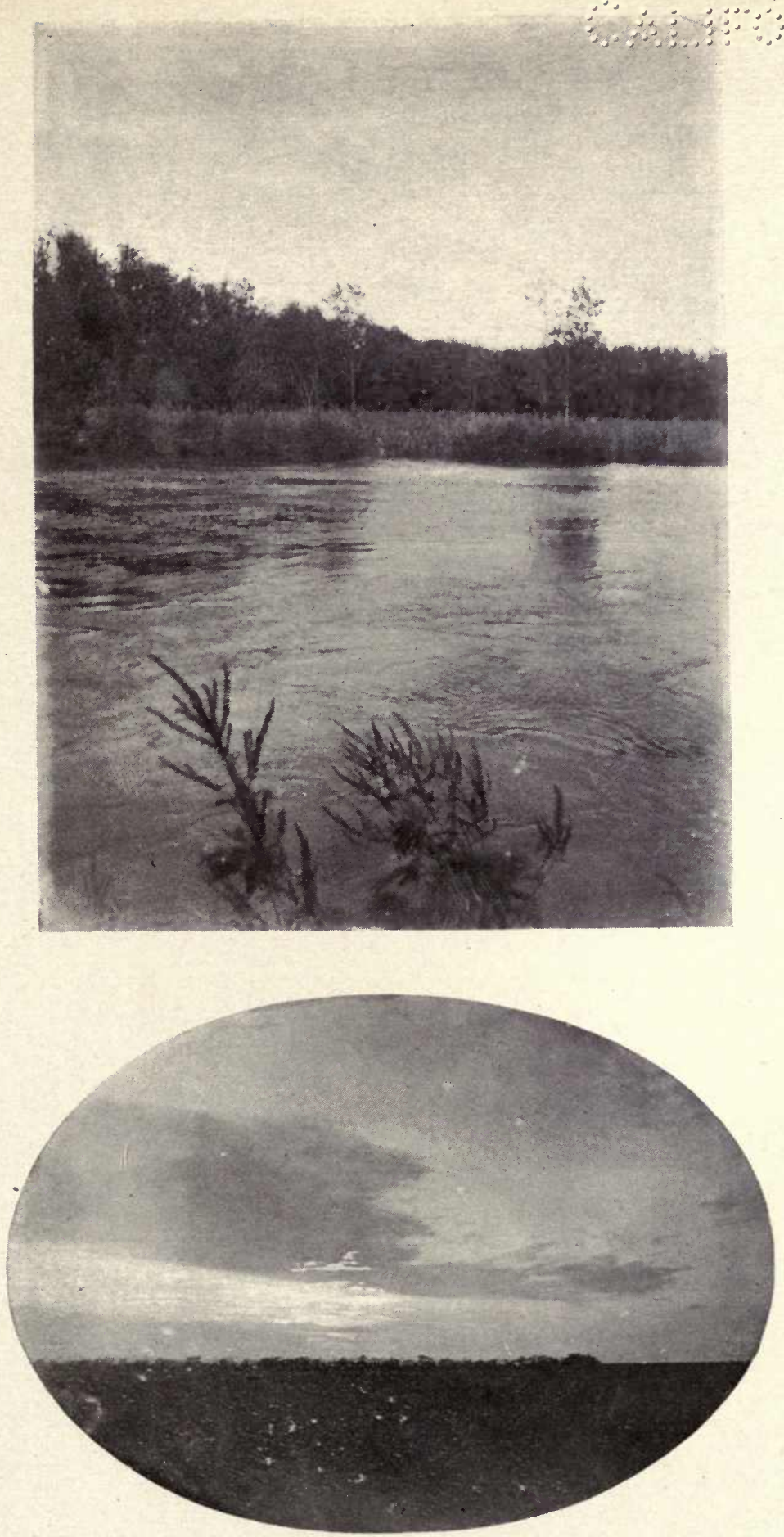



\section{The Wind}

The wind was out in the wheat playing at the big and blessed business of making beauty. The wind is PAINTER as well as sculptor.

Have you watched the wind on the water? You can see the wind's footsteps, but you can not see its feet. You know the footprints of the wind on the water. You know who has been walking there, for who else could make such footprints on the water? The wind was walking on the water-that much is sure. That is why the wind's feet sometimes wet our lawns and gardens and fields - the winds have been out walking on the water. How far has the wind come? Whither goes the wind? Does the wind ever tire traveling the far spaces of the sea? How could the wind ever grow footsore stepping on the soft surface of the sea. The wind is a tireless traveler on the highways of the sea. But the wind is making beauty, withal, out there upon the sea. The deft fingers of the wind touch the sea's face into a thousand smiles of wimpling waves. Many of the most beautiful wavelets in the hollows between the waterhills on the sea are the workmanship of the wind. The tide is at work heaving up the hills, but the wind is working with the tide. If you have watched the waves and wavelets, the wrinkles and crinkles out on the sea, then you have seen this wonder-worker in beauty making beauty on the sea. All the Hogarth lines are there marked out by this draftsman of the sea. I will watch the wind-work on the waves and find in them the perfect artistry of God.

Have you heard the wind in the pines, the wind in the mountains? I have stood under the tall pines in Yosemite and have heard the winds sing. The winds sing? Yes! My friend, who prides himself on his balance and intellectual 


\section{Meadow and Mountain}

poise, says that he never heard the winds of the mountains sing. Well, I suppose he has heard them snore and roar! I am sorry for my friend who has no ear for this wind-music, for I have heard the winds sing. Musical hints of all the wind instruments are there. The bugle blare, the drum roll, the deep organ tones, the Vox Humana-they are all in the mystic orchestras of the wind. I have stood under the towering tops of the great Sequoias and felt upon my brow the slow-blown breath of the centuries. Among their high heads are the music-thunders of the wind. The thunder's staccato wakes wild echoes among the mountains. The sublime obligato of the storm has sung for centuries through the tops of these tall trees. There are voices in the wind. There is music in the wind. The wind is not only a factor in the making of beauty in the snow, in the sand, on the sea, in the meadow, on the wheat, but the wind is also a maker of MUSIC everywhere.
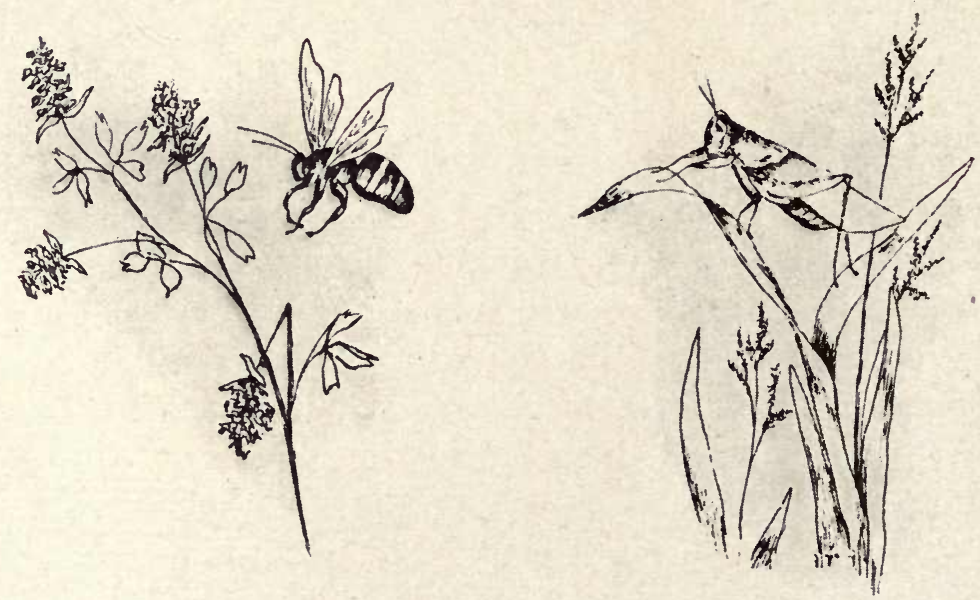


\section{THE WIND}

Wandering winds moaned through the trees,

Like serried sobs of restless seas;

And tree-boughs swaying low and wide

Groped in quest of days that died,

Murmuring soft and whispering low,

Mournful speech of midnight woe-

"Farewell, Summer, long farewell."

Solemn shadows softly fall, Lying like some funeral pall,

On dead leaves and dying grass,

Where the winds are saying mass;

Moving noiseless, cold and dim,

Shadow phantoms gaunt and grim

Bow sweet Summer, "Long farewell."

From the drifted leaves emerge

Cricket cries of autumn's dirge, And dismantled treetops quiver, Like long reeds in rushing river, While the winds 'mid shadows blow, Half-articulate with woe, And long-drawn sobs-"Fare-well, fare-well." 


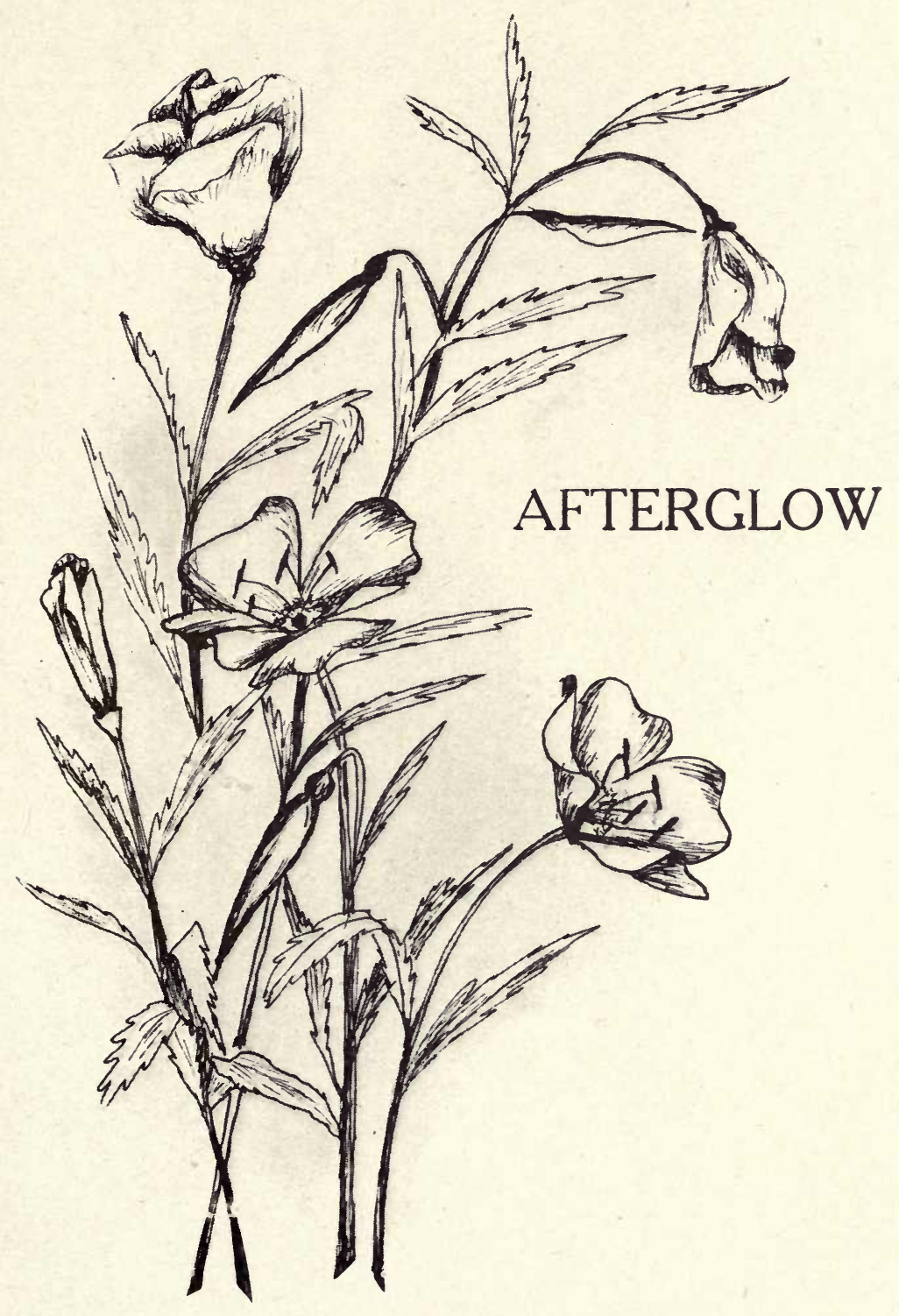


$\because \because y$

$\because \vdots \vdots \because \vdots \vdots$

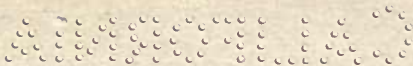




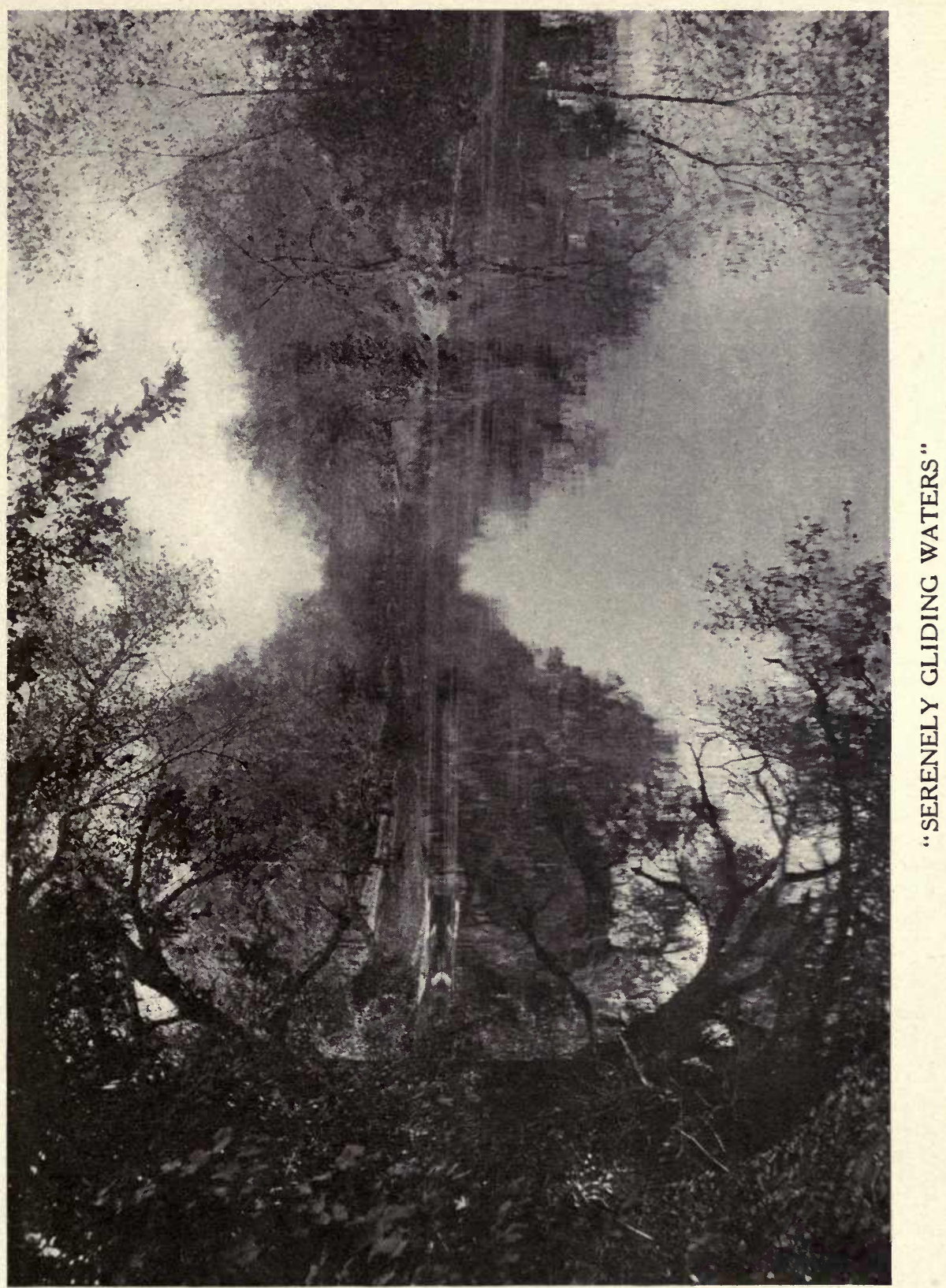


$\because \because \vdots \quad \because \vdots \vdots \vdots \vdots \vdots$

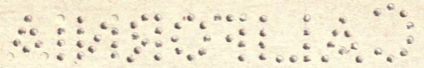




\section{AFTERGLOW}

THE time was late autumn. All day the spendthrift sun had flooded the prairies with splendor. Like a huge sphere of red flame he slowly settled in the far-away west. A silence that made one's heart throbbings audible brooded over the prairie meadows. No fleck of cloud was on the flawless sky. Here and there a stellar flame had burned through the overhanging veil of blue. It was a time to wait and watch in heart-hushed wonder. No whisper of wind ruffled the stillness. The noiseless flow of evening twilight spread in silence everywhere.

A faint flame glimmered across the western sky, and light lingered as if loath to leave the world in shadow. It was like a lover throwing kisses back to one from whom he must be parted. Almost white at first, then orange-yellow, then red like iron that feels the fire still, then deep scarlet, growing deeper, till it dies amid the darkness and the dew. Then the whole blue field of the sky broke into astral bloom.

A lonely watcher read this meaning in the farewell gleam of the afterglow:

Let the light of thy life linger long with the living, When the sun of thy life shall set in the evening; Let the words of thy song sound after the shadows Have folded the singer away to his rest. 


\section{SURPRISES OF THE PRAIRIE}

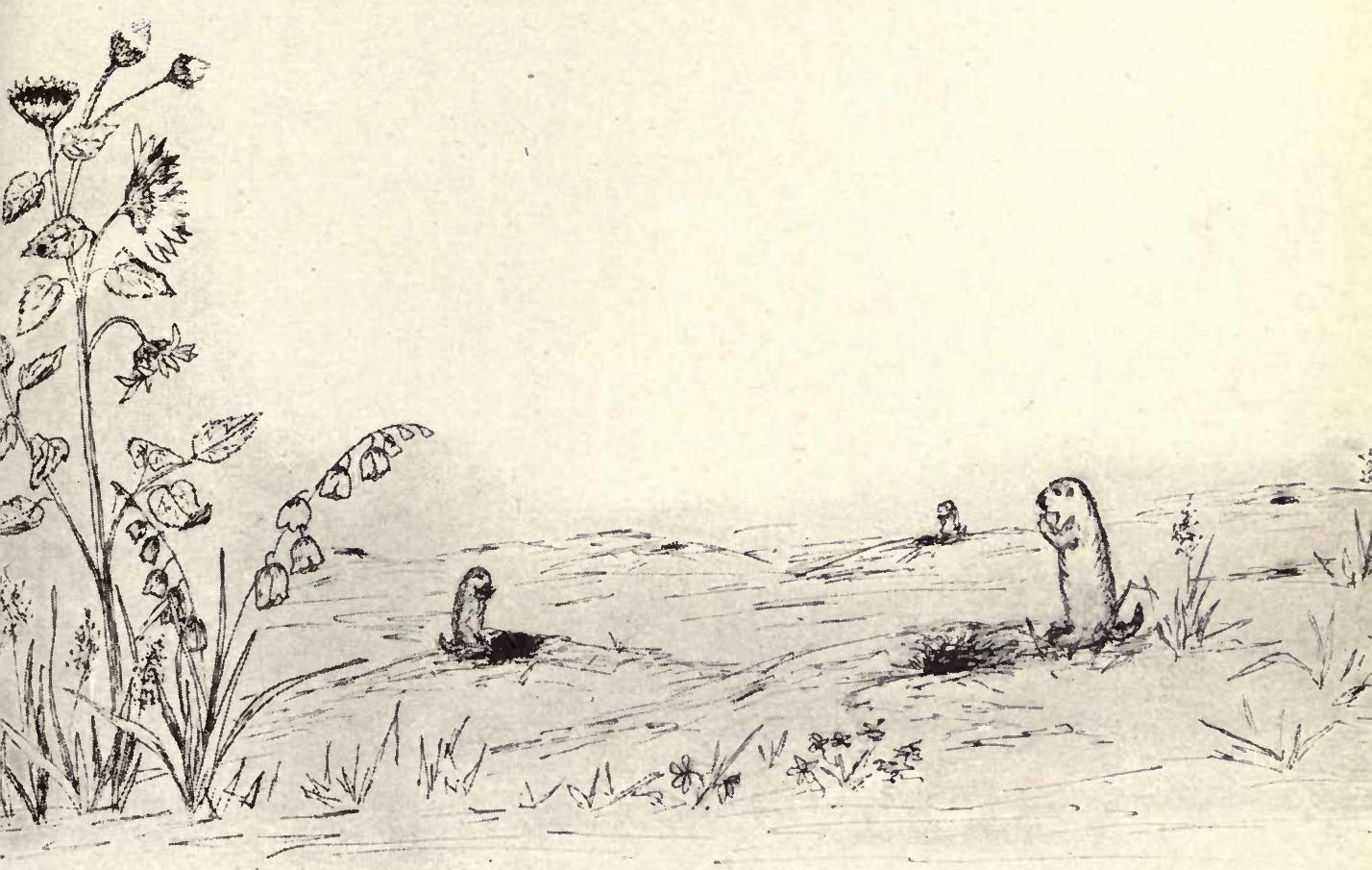




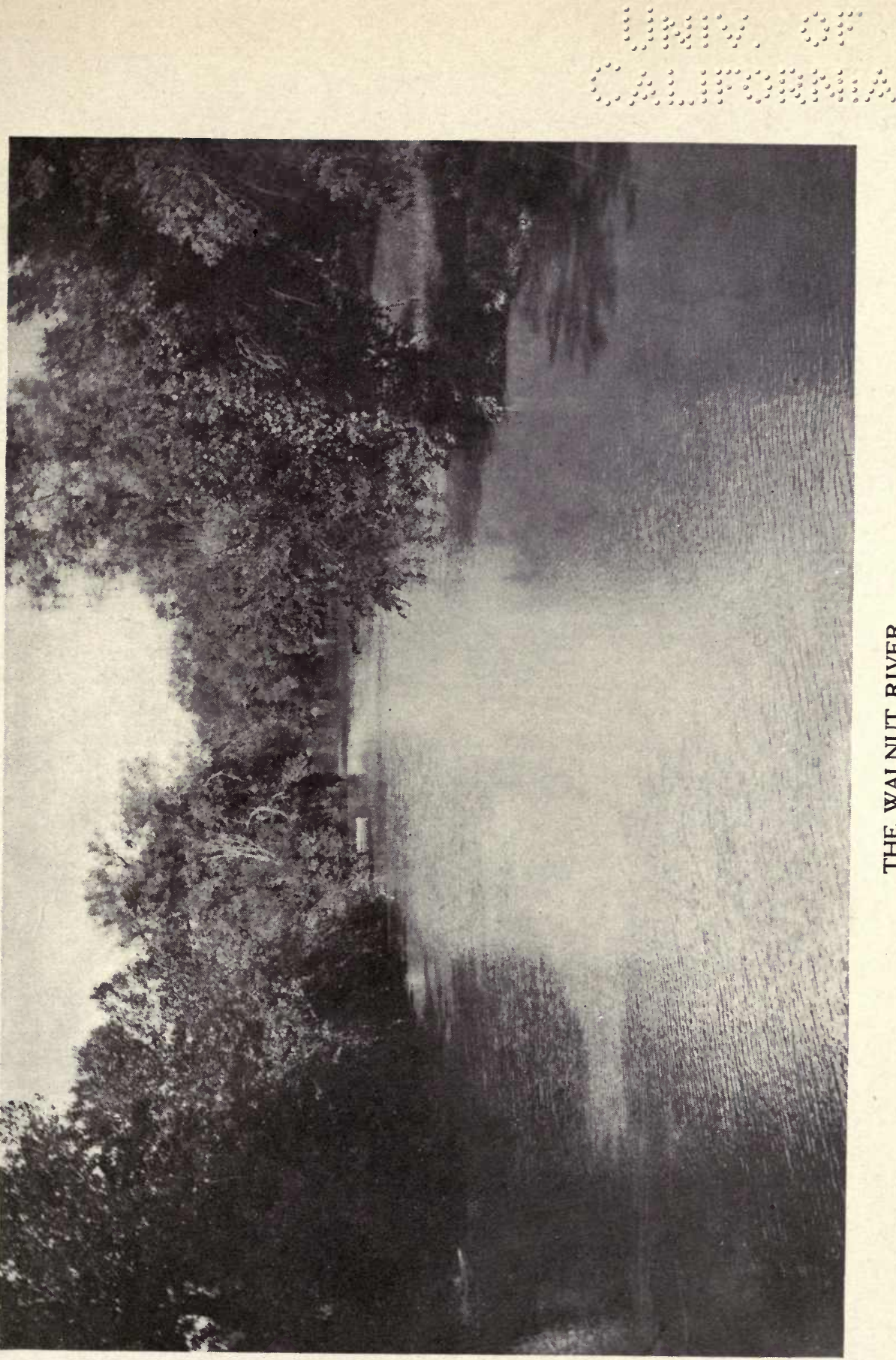

告 


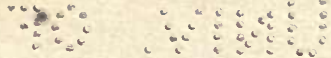

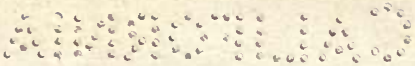




\section{SURPRISES OF THE PRAIRIE}

THE idea held by people of hill countries is that prairies are treeless. And as for the prairie river, it is never dreamed of in their philosophy. Also "breaks" and "buttes" are a part of the prairie perspective. These are called "hollows" and "hills" in timbered countries. These and many other things are among the surprises of the prairie. We excuse our Eastern friends for asking if Kansas, Nebraska, and Iowa have any trees. We excuse these friends for wondering whether there are any rivers in these prairie States. Our friends are incredulous when we tell them that there are thousands of prairie trees as big as hogsheads. Concerning such matters, these kind friends say among themselves, "Well, our Western friends do not mean to exaggerate." The uninitiated "tenderfoot" can not take in the truth about our prairie trees. These Eastern friends of ours are courteous. They are not contentious. They kindly apologize among themselves for our verbal extravagances. Well, apologetics are good for some people.

Out there in the open field is a coffee-bean tree. It is five feet in girth and thirty or forty feet high. Its leaf resembles that of the black locust. It is as free of thorns as the maple tree. Its branches are shapely and beautiful, and that is true of almost any tree. Its bean-pods in the early autumn look like bananas. They are like politicians, and are hard to shake off. I have seen a large coffee-bean tree full of black pods in mid-winter. But dismantled as it is of leaves no one would call it unbeautiful. I know such a 


\section{Meadow and Mountain}

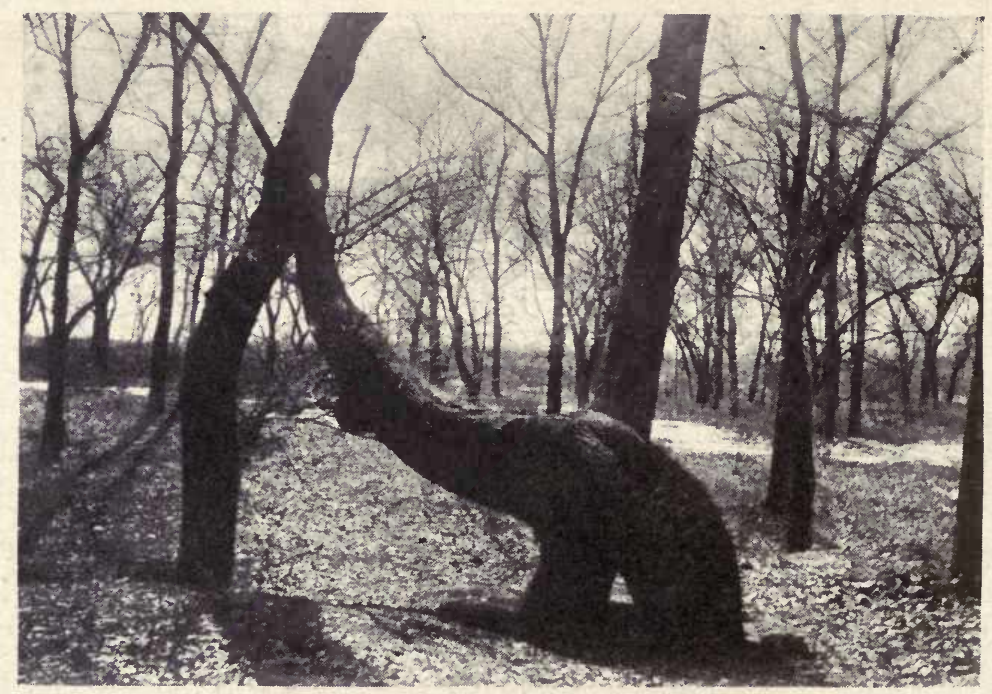

tree at the edge of a country lane. I have seen wild grape vines entirely conceal the tops of tall trees. The leaves in summer are close enough together to shed rain. It is one of the luxuriant wonders of the wild. When a vine grows up on the prairie, does the tree come for a trellis? Or when the tree grows up, does the vine come for a covering? Of one thing you are sure. You know that the tree and the twining vine together are beautiful. There are the "triplet trees," literally grown into each other's life. They stand by the bank of the Walnut River. A sight of them would surprise your eyes.

Gravel hills, sand-dunes, and buttes are God's contrivances for displaying the dimples on the face of the prairie. These are the products of wind and weather. The wash of rain has wrought mysterious masonry here. You will be surprised to see among the buttes towers, pillars, castles, walls, chimneys, fortresses, broken columns, and the 
$\because \vdots \vdots \quad \because \vdots \vdots \because \vdots \vdots$

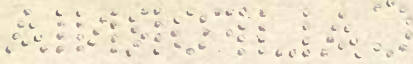




\section{Surprises of the Prairie}

like. The prairie eagle loves to perch and dream amid this desolation. But he wakes and watches betimes to "view the landscape o'er." You will wonder when you see the waft of his wing as he lifts himself to fly away. He is clumsy on foot, but he is wonderful on the wing.

The winds have blown the sands into yellow drifts and made the dunes. Many of these drifts are marked with curves and lines and sandy circles in a marvelous manner. It is worth facing a sand-storm to see this tracery of the wind. The tapestry artist and the draftsman might find some new models here, and all of them "true to nature."

Now and then you will see a gravel hill which is the subject of prairie traditions. Arrow-heads are sometimes found

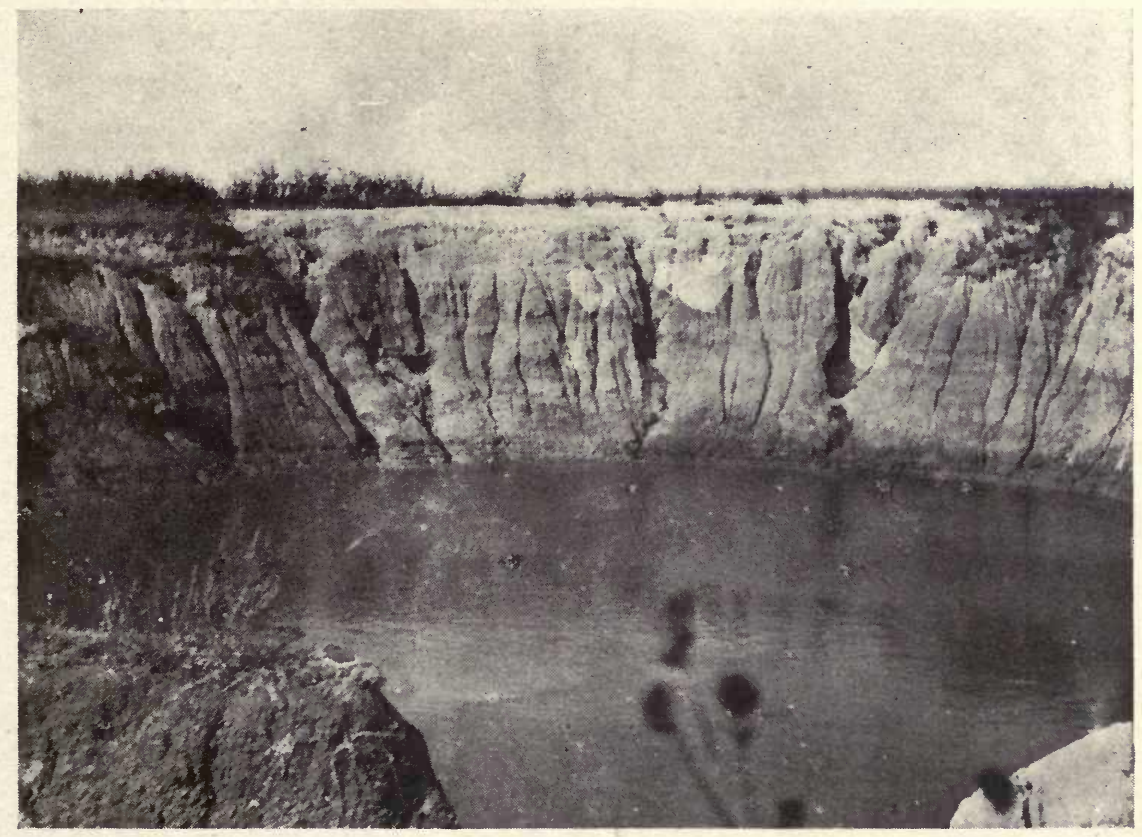




\section{Meadow and Mountain}

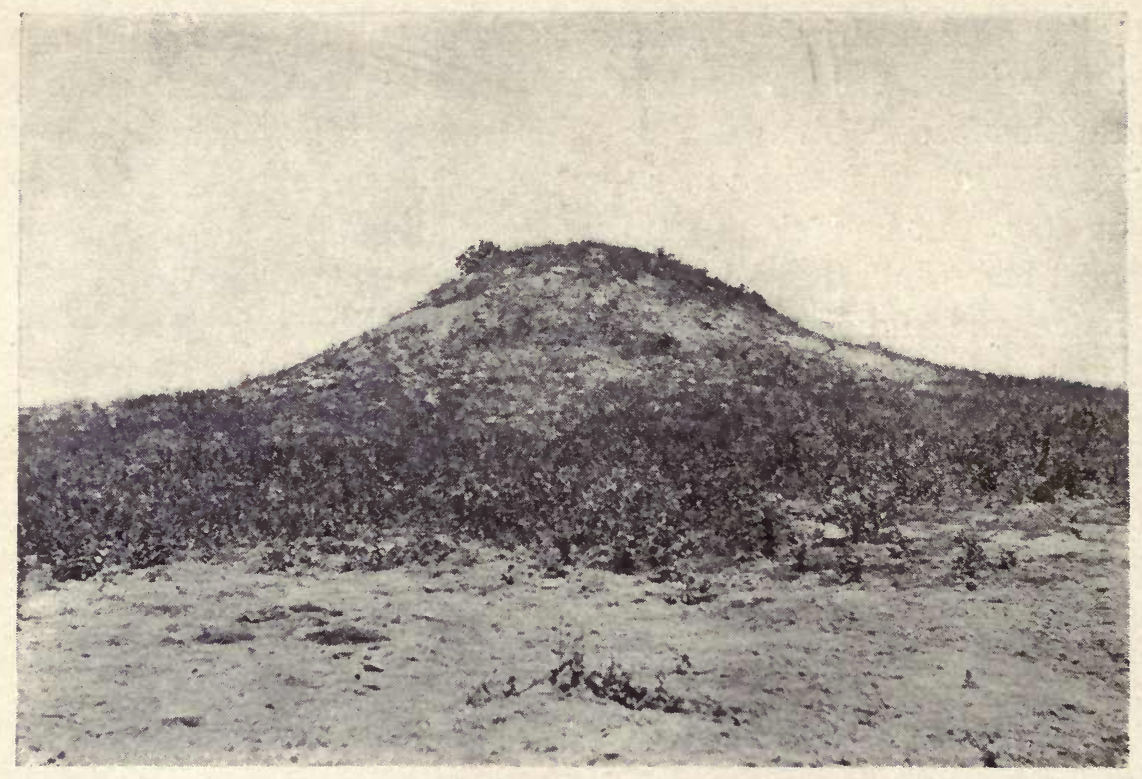

about these mounds. Such discoveries give rise to Indian tales. Some prairieman will tell you that a fierce battle was fought here in the early days of the ranchman and the ranger. Who knows but this is a monument to a hundred brave chiefs who fell with their faces to the foe? A reminiscent air hangs about this little hillock on the prairie. Some beautiful beads have been found around these places.

The sod-house of the prairie has been the place of prophecy and dreams. Its earth-covered roof has sheltered many a strong soul. The pioneer of bygone days braved the weather and wind to sow these prairie stretches with wheat and maize. He has been long away from this house of sod, and the wild grass grows about the place and the winds moan as if for him who now is gone. The screech-owl loves 


\section{Surprises of the Prairie}

this loneliness, and sends his tremulous call across the moonlight and the night. The dolorous sound of the coyote's cry is added to the din that dies away and comes again from evening dusk until the dawn. And when the shades of night have fled away, the morning sunlight streams athwart the sod, irradiating all the grassy range.

On a pony trip of fifty miles you can count as many as fifty varieties of wild-flowers on certain stretches of Western prairie. You will not think of loneliness, but loveliness, as you take this journey. While you talk about the windblown West, do not forget the beauty-blown prairies. On an April day you will see a bunch of buff in the short green grass for a distance of a half-mile. It is the buff baptisia. The blossoms stand around a central stem. They sometimes branch and form two or more blossom stems. The

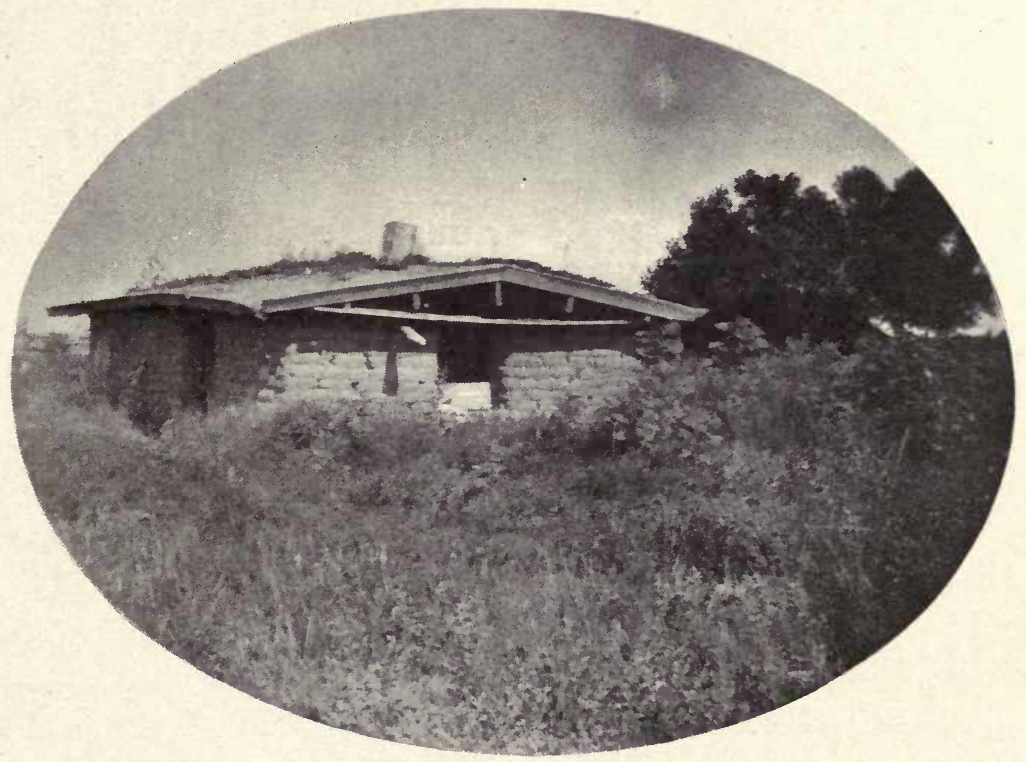




\section{Meadow and Mountain}

botanist calls them "false Indigo," but I dislike the name false applied to a flower. The Indigo flower itself is as blue as the bluebird. They are never numerous in any one place. They grow from one to three feet high, and their branches are as shapely as those of a sycamore tree, and as smooth as that tree's trunk when the outer bark is shed. Seed-pods come after the flower falls - a yellowish green at first, but turning black as autumn comes. Cut by the sickle and stored in the mow with the prairie-hay, the Indigo flower

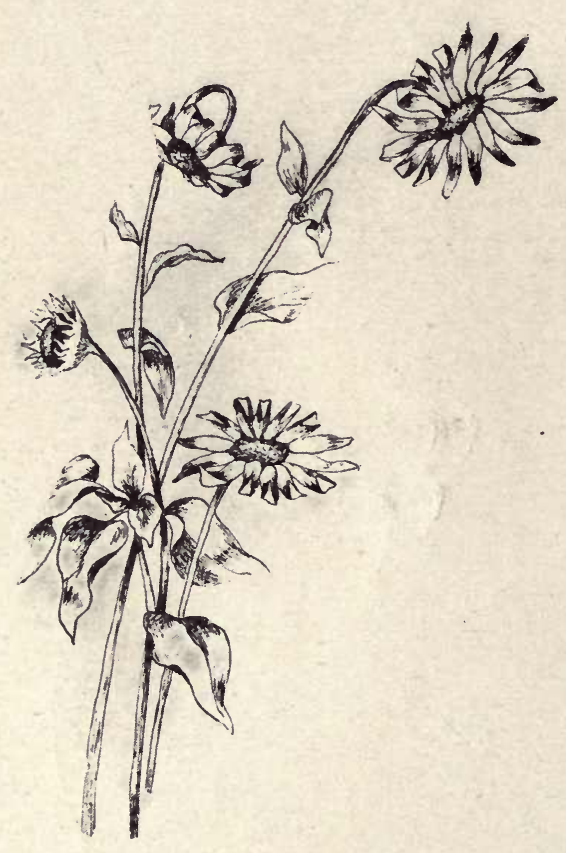
turns as black as night. In its virgin vigor its leaves are a mild-green, with a slight touch of silvery stuff on the surface. The Indigo flower in bloom is beautiful enough for the lawn of a palace, and as blue as God's sky.

There is no flower more widely known than the sunflower. It will not long endure the shade. Most of all the prairie flowers, this one is the offspring of the sun. The bloom is fairly burnished by the light. A field full of sunflowers, full-blown, is enough to kill a pessimist, or cure him forever. When such a sea of brightest yellow billows in the wind, my very soul swims out upon the scene. That field is more mine than it is the man's who owns it, if he be blind to beauty. Heaven, unblind him! 


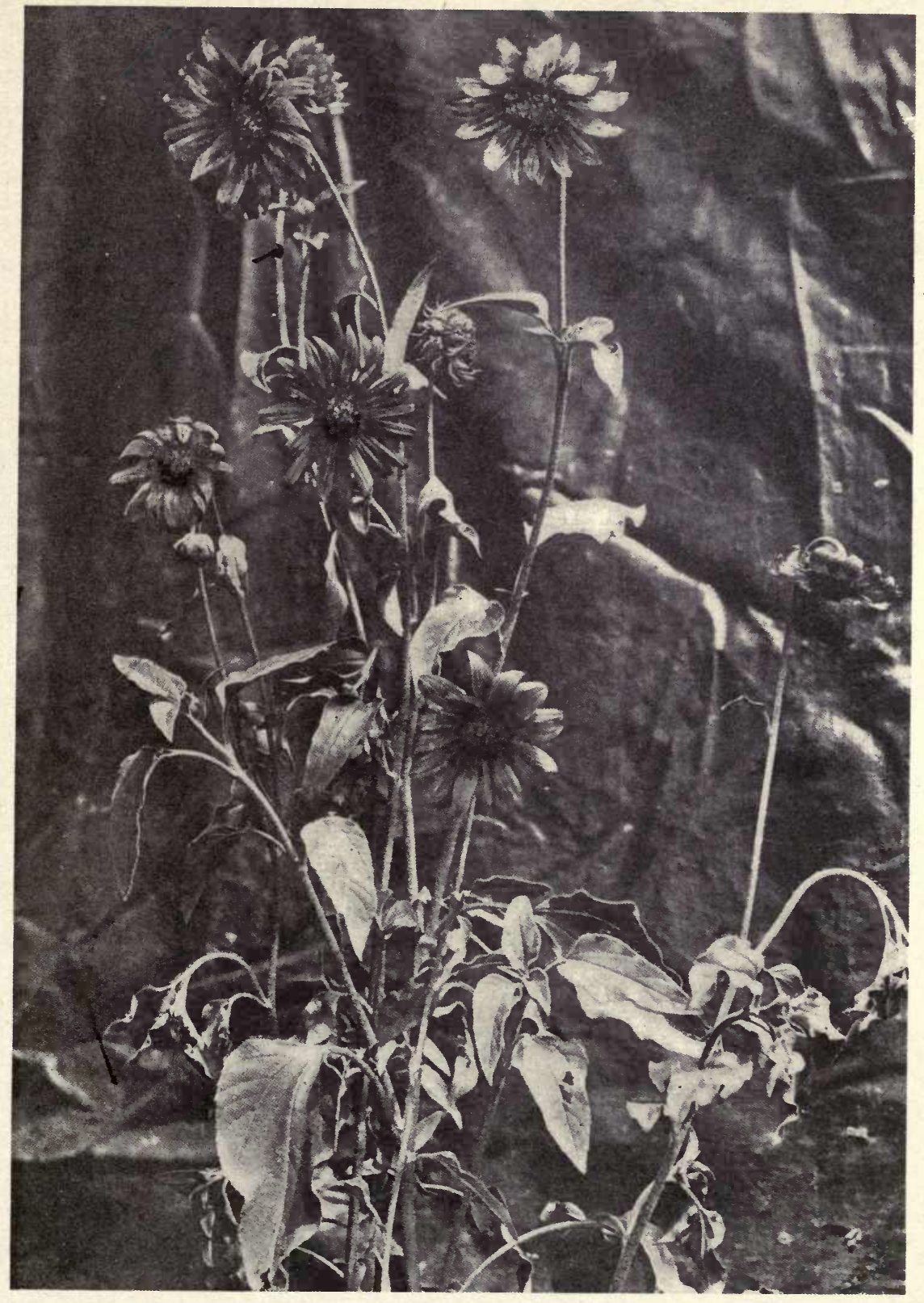

SUNFLOWER 


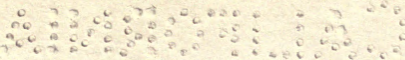




\section{THE SONG OF THE SUNFLOWER}

I sing with my feet in the soil of the free,

A sun-woven crown I wear,

Rare nectar I give to the sweet-laden bee,

And flaunt my bright banners in air;

The Sunflower State is the kingdom for me,

Where the sun filters gold in the loam, Where flocks and herds and the fruit-laden tree,

And the corn tassels mind me of home.

I flourish by trails on the high hill's brow, I lift me aloft in the vale,

Where the whistling farmer drives his plow,

Or whirls his threshing flail;

Empires I sway in country and town,

But gladly I yield my domain

To the toiler who covets a worthy renown,

Through orchard or garden or grain.

I fence the highways with hedges of gold,

I beautify ruins with flowers,

With yellow and green I border the wold,

And shelter the birds in my bowers;

I nourish wee creatures that creep on the ground,

I feed the fine fowl of the air,

And where the footsteps of the farmer abound,

I scatter my flower-flakes there. 


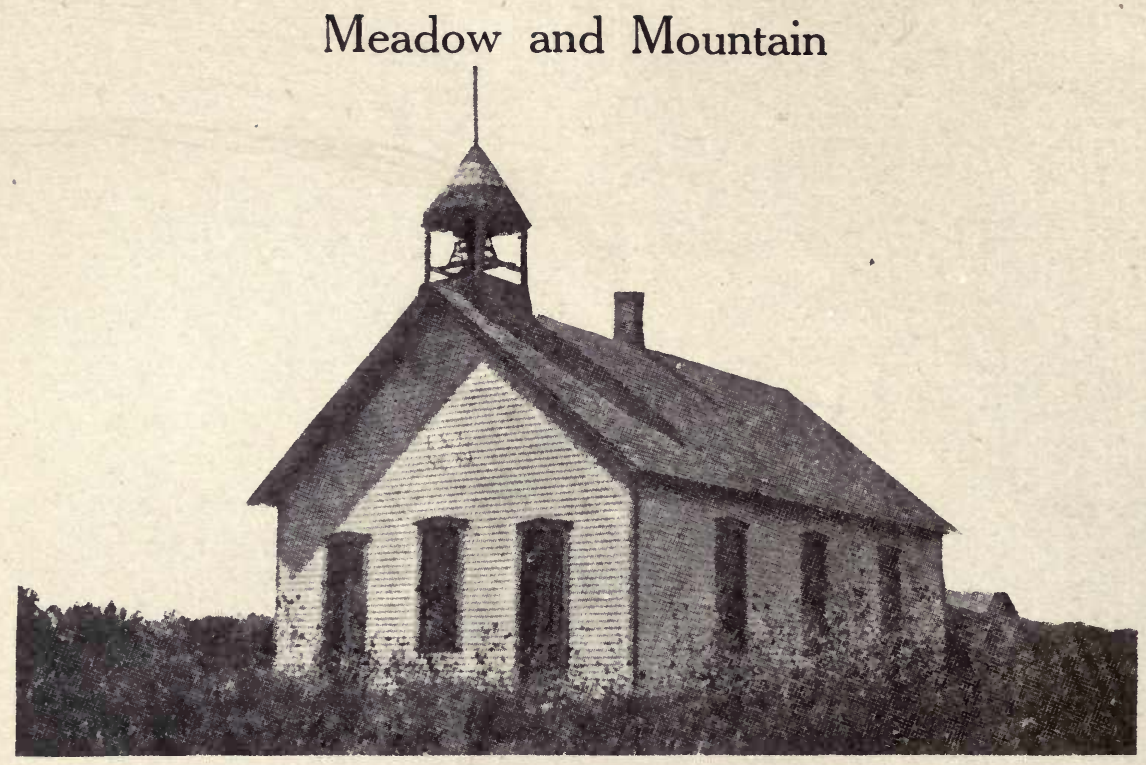

The lone schoolhouses along the lane

That leads to the rural retreat, Will blossom with human flowers again

At the coming of Autumn's feet;

Till then, like a sentry on guard, I stand

By the door and window sill,

To await the return of the youthful band, My beauty to plunder and kill.

Then I silently sleep in my seed-pod tomb, Till the frolicking throng tread me low, When I gather the stuff for my beautiful bloom, While the winter winds murmur and blow;

My beauty was plundered to crown me with more, But the ruin seemed out of all reason, Till the new life woke in my slumbering spore And sceptered me Queen of the season. 108 


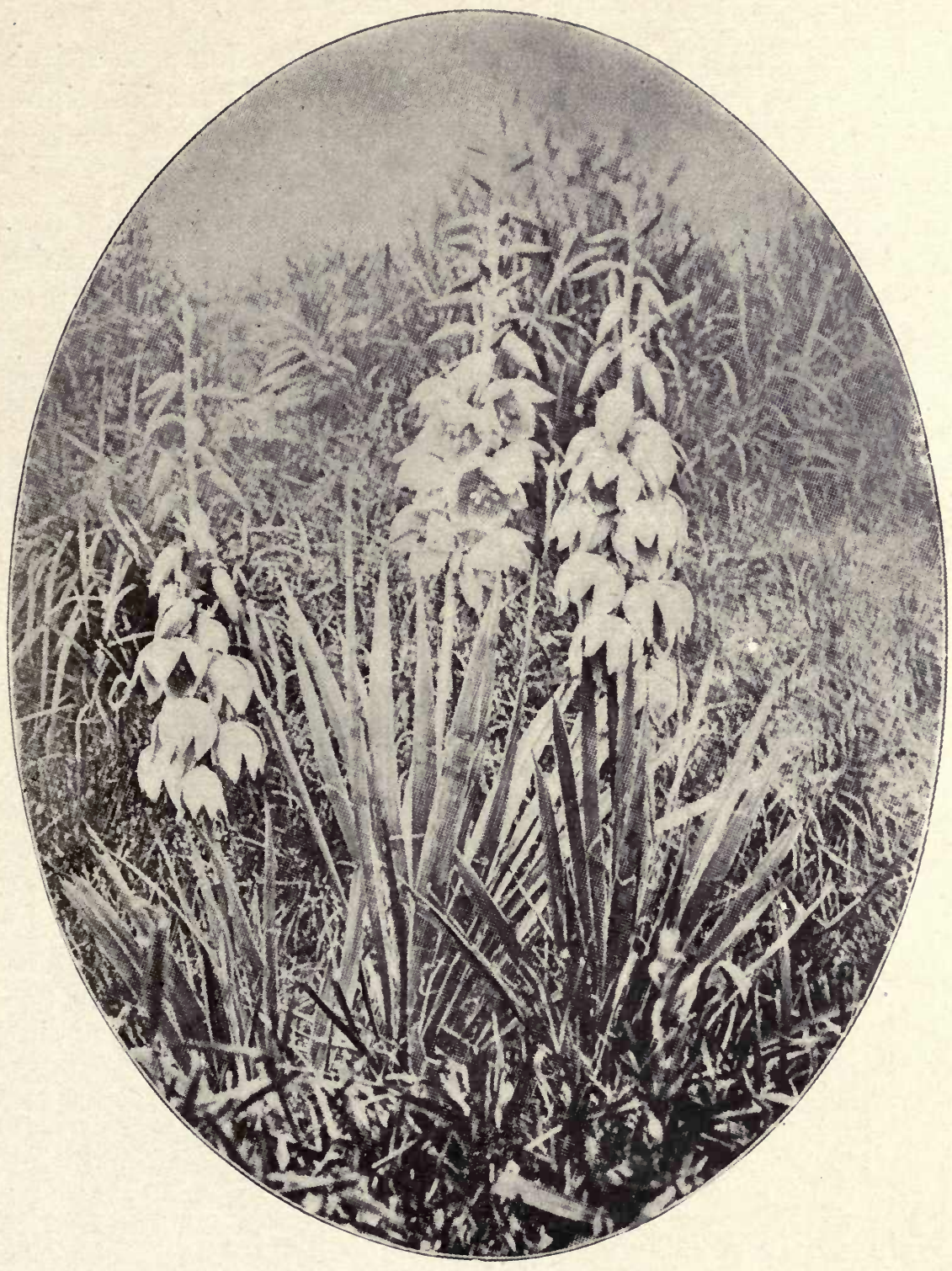

THE YUCCA BLOOM 


\section{Meadow and Mountain}

The "Spanish Dagger" is an ugly name for a beautiful thing. The prairie does not produce a more beautiful sight than the Yucca in full-bloom. Its long, tough, and dark-green leaves are as pointed as daggers. They grow upward and fall outward from the center, forming a sightly tuft of graceful leaves. The Yucca is evergreen, and defies the blizzard of the range. The roots are as tough as hemp ropes and astonishingly long. A first-class soap is made from these roots. On a level stretch of prairie you can see the "Spanish Dagger" for a mile. The long stems about which the blossoms unfold shoot up from the center of the tuft of darkgreen leaves. The outside sheath of the blossom bud is a light-green. Just before these blossoms unfold they have the appearance of green bells, for the inner creamy-white is not yet visible. The bloom-covered stems taper like a steeple toward the top. The center at the base on the inside is a greenish-white. You will see traces of palish-pink as the beautiful flower begins to fade. Then the seed-pods come and hold for months where the blossoms clung. These dark-brown pods make a beautiful contrast in mid-winter above the untarnished whiteness of the surrounding snow. Some little bird of the prairie may find a shelter here from the keen cold. You will trace his tracks in circles around the big tuft of Yucca leaves. Then you will wish for the days of summer, when the beautiful Yucca shall bloom again.

The "Sweet William" is a child of the prairies, but I have seen him flourishing in the warm woodlands of the Walnut River valley. I have caught his fragrance in the wind as the sunlight sifted through the budding trees. The 
Surprises of the Prairie

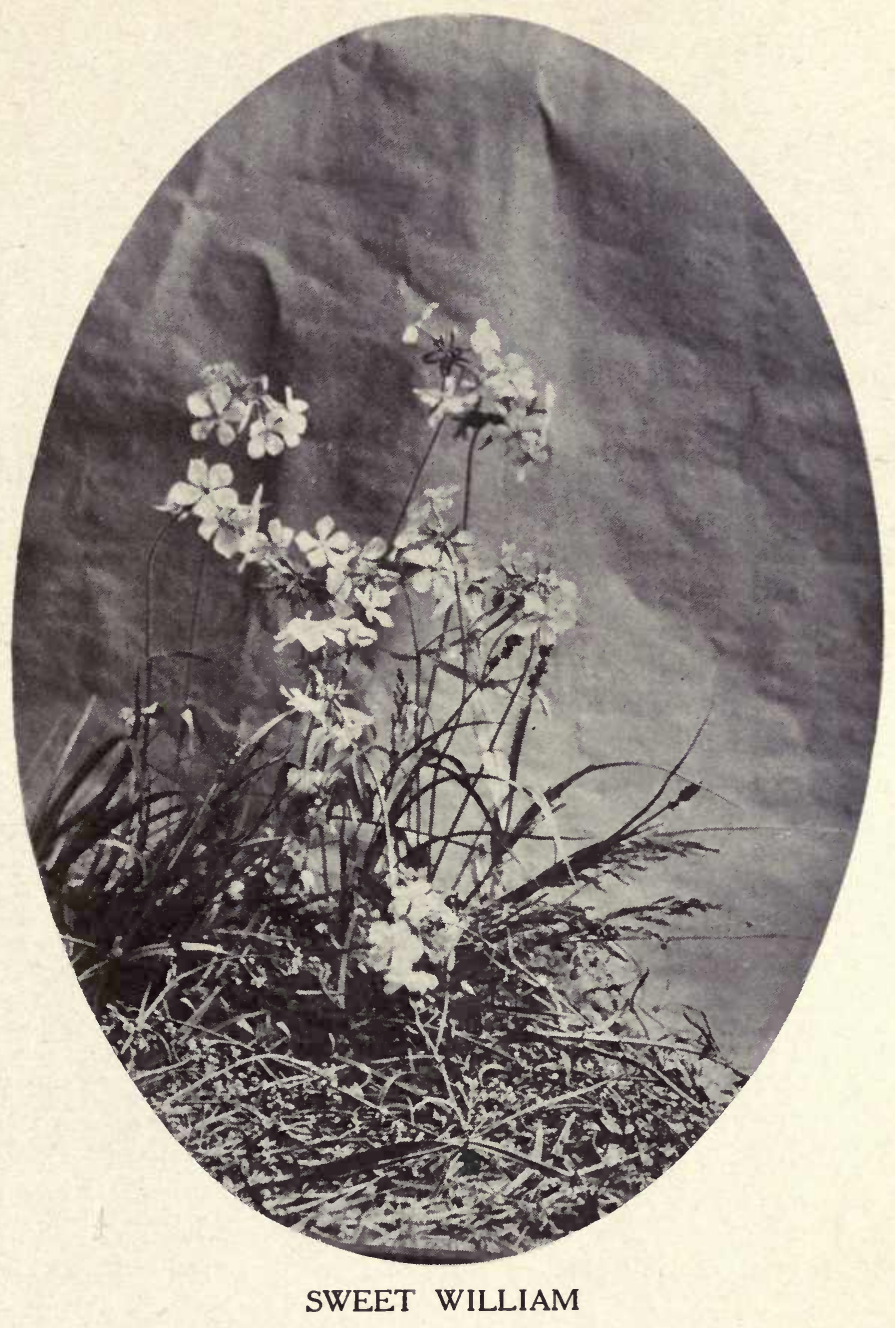

time of the singing of birds had come, and the humming of bees. In the open meadow it seems a pity to cut this beauty down when the sickle comes to mow the hay. The bloom of this flower has several shades of pink. I have seen them altogether white, and shading from that to a lovely lilac. 


\section{Meadow and Mountain}

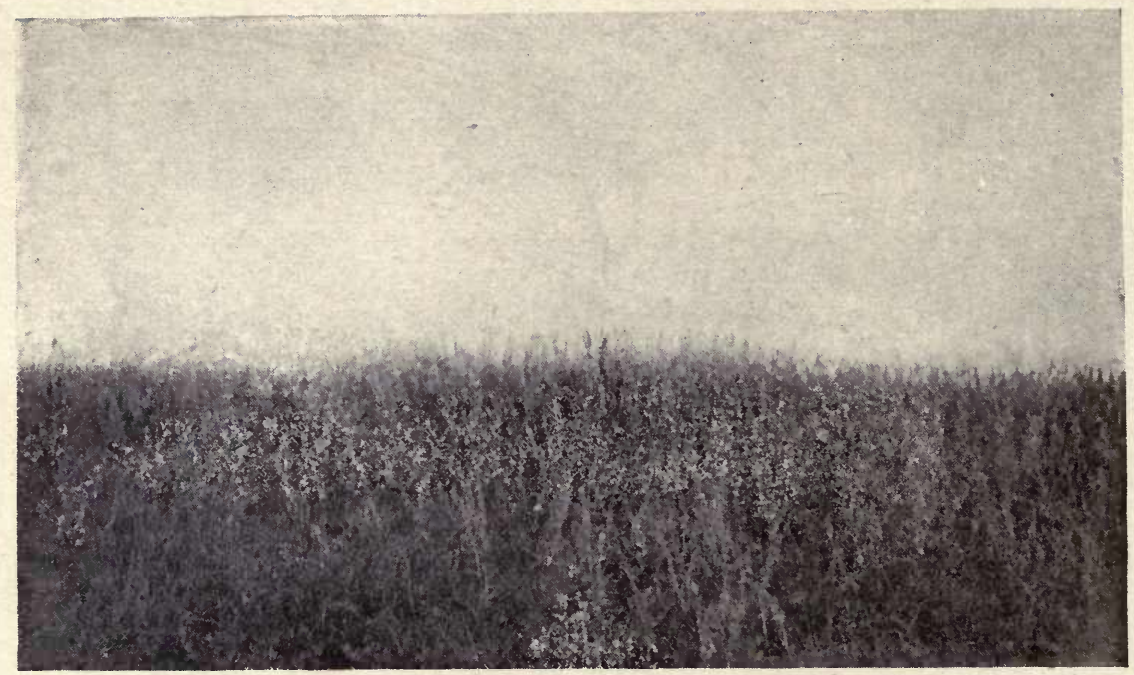

THE WILD SILVER SAGE

The lance-shaped leaves are dark-green. This five-petaled flower announces that spring has come again and that it is safe for the bluebird to spill his welcome warble on the wind.

The wild-sage is a conspicuous product of the prairies. More and more, as autumn comes, this plant looks as if it had been sprinkled with dust of silver. Its frosty features are prominent in the midst of the brown bunch-grass, and you will see it rods before you reach it. Only dull eyes would not be charmed by this beautiful silver-gray among the grasses. Tea brewed from this sage is as bitter as the leaves are beautiful. Though, if you chew the leaves a little, and then free your lips of them, a pleasant sweet will be the last taste they will leave on your tongue. The seed-pods of this sage are as pungent as those of the old-fashioned garden sage. 


\section{Surprises of the Prairie}

The kinship of the two is easily discerned. When you see a prairie hill-slope overgrown with wild-sage you will wish to linger there and see the lights and shadows shift among the silver leaves. Some October day will do for such delight.

The sage hen loves to hide among these pungent pods of the prairie. The silver-gray of her plumage helps to hide her in the silver-sage. On such a sagey slope as this you can seldom see the rabbit till your foot is at his side. To the little gray birds of the meadows these are nothing less than groves of sage trees. I think they seek the pungent seeds of the sage when other food is scarce. Whether at dawn, when the dew is on, or in the shimmer of the noon, or in the gray of evening gloam, there is a charm about this sage of the wild that lures the lover of the grass and the flowers.

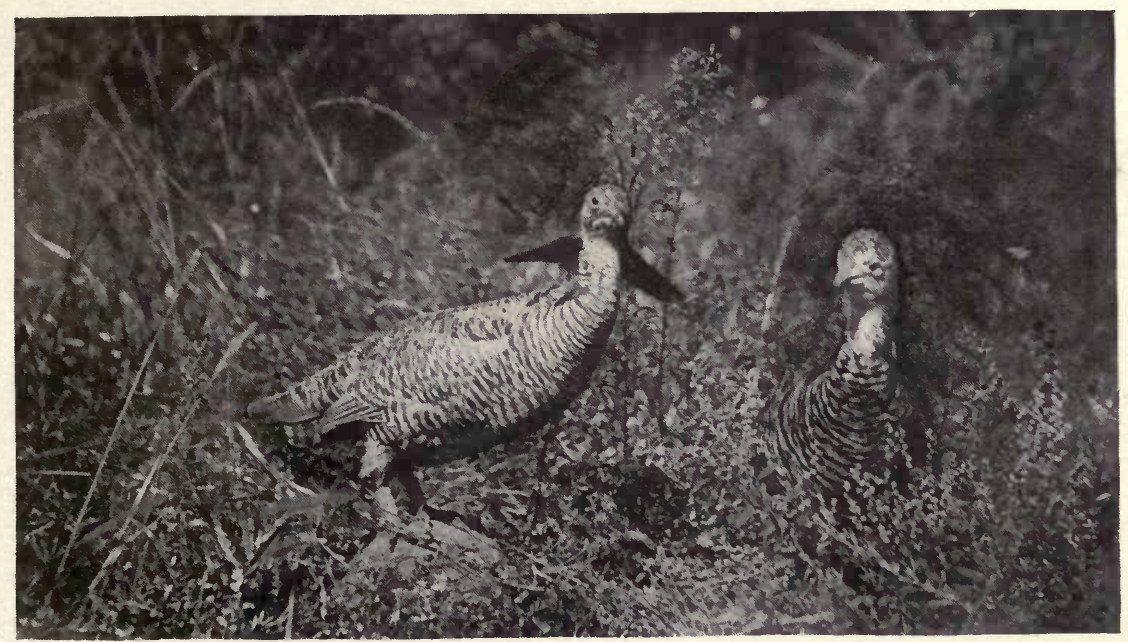

THE SAGE HEN 


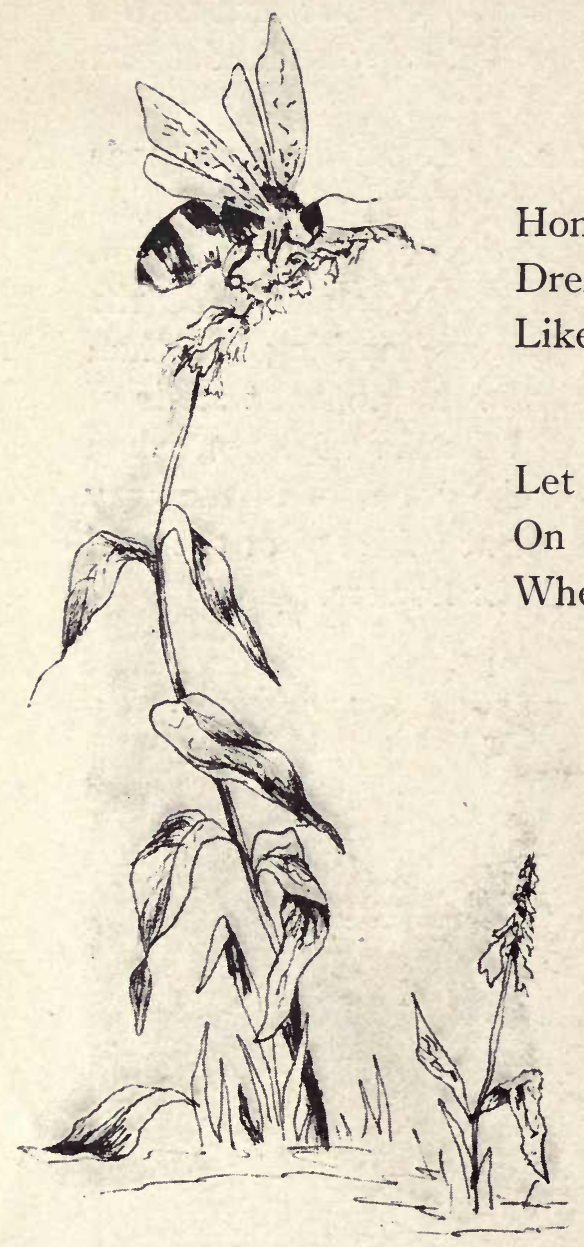

\section{THE SALVIA}

Honey-throated flower of blue, Drenched with starshine and the dew, Like God's mercies you are new, Every morn to me.

Let your minty fragrance flow, On the gentle winds that go Where the sweet wild gardens blow,

Out in the meadow fields.

I have seen the bumblebee Clinging on this flower tree, Swinging slow in sleepy glee, On a summer's day.

Could I clasp such cups of blue, Feasting full on honeyed dew, Then were I as glad as you, Far-flying bumblebee. 


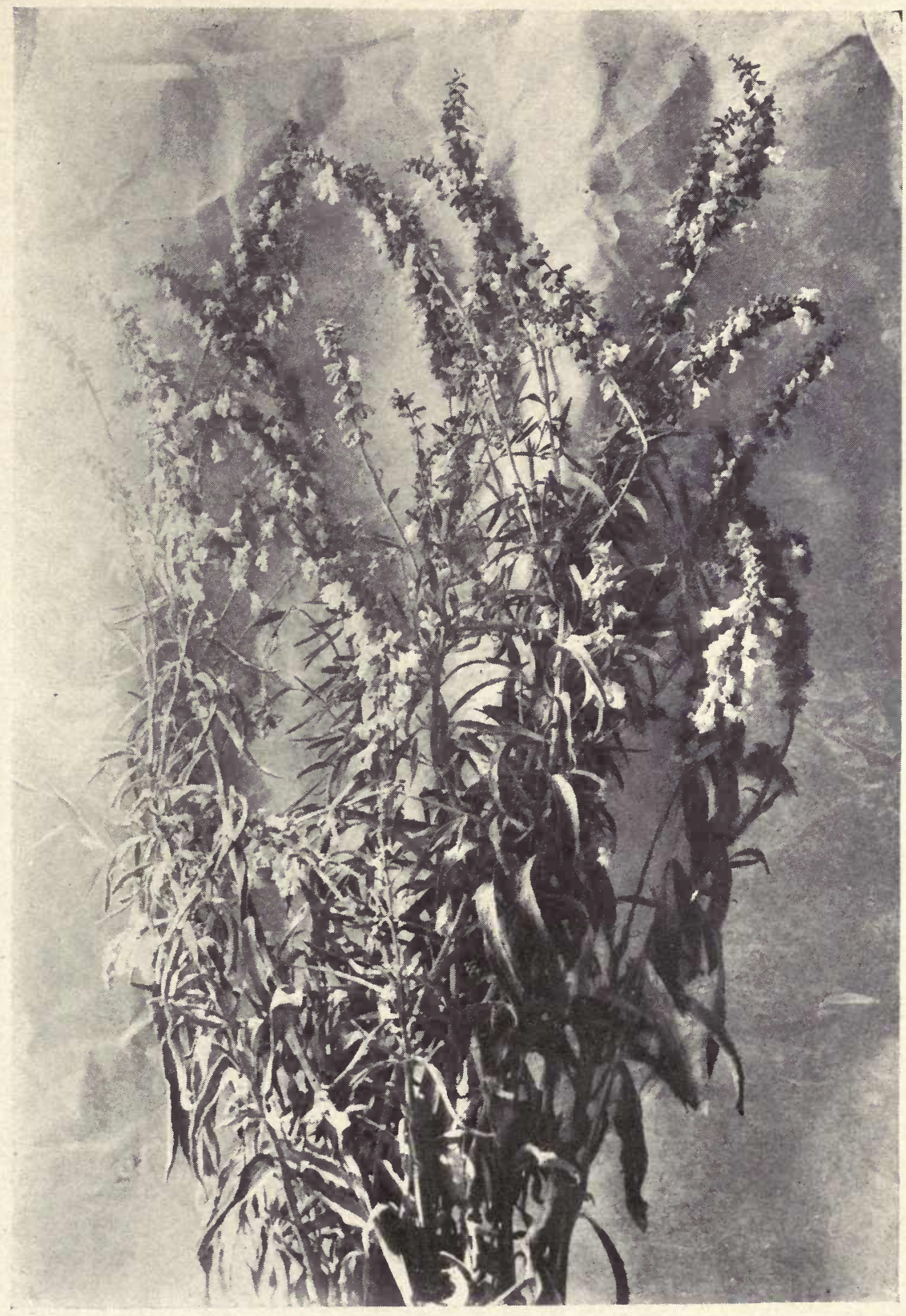

THE SALVIA 
$\because \vdots \vdots \quad \because \div 2 \div \vdots \vdots$

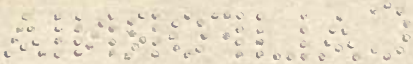




\section{Surprises of the Prairie}

The salvia also belongs to the kindred of the sage. It grows from two to four feet high. Its scent is decidedly sagey. The blossoms are a beautiful blue. Their shape is similar to those of the garden sage. The bluish effect of their bloom is better at a distance than near at hand. It is unaccountably strange that the lower lip of this thing of beauty should have the shape of the swine's chin. But it has caught the color of the sky, and that saves it. When you know nature, you will expect to see strange sights. Who would think that the blossom of "the devil's hook" would look so much like the catalpa bloom. But the resemblance is strikingly close. No one thing has all the beauty. It is distributed far and wide.

The salvia loves the roadside. When the wind was on the prairie I have seen the bumblebee swing and swing as he feasted on the honey in this flower. He falls in with the wind, and has his own way. He wastes neither strength nor time in combating the weather. He is not looking for trouble, his quest is for honey. When he dips his honey-spoon in that blue chalice of sweetness he rises and falls with the flower in the wind. He has a good time, but he does it by adapting himself to things and not by adapting things to himself.

"Seeing only what is fair,

Sipping only what is sweet,

Thou dost mock at fate and care,

Leave the chaff, and take the wheat.

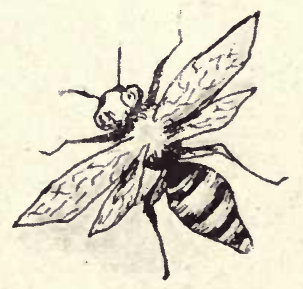




\section{THE GRASS}

There are sunbeams in the grass,

Greeting shadows as they pass, Shade and shine alternate quiver, Like the moonlight on the river-

$\mathrm{O}$, the glimmer of the grass.

There are gardens in the grass, Things abloom in tangled mass, Smiling summer breathes around, Tang and odor of the ground-

Through the fragrance of the grass.

Little schools are in the grasses, Here the teachers call their classes, Teach them how to run and fly, How to sing instead of cryLittle schoolmates in the grass.

Little homes are in the grasses, Dewdrops are the looking-glasses, Tiny leaves are baby pillows, Softer than the pussy willows-

Little pillows in the grass. 


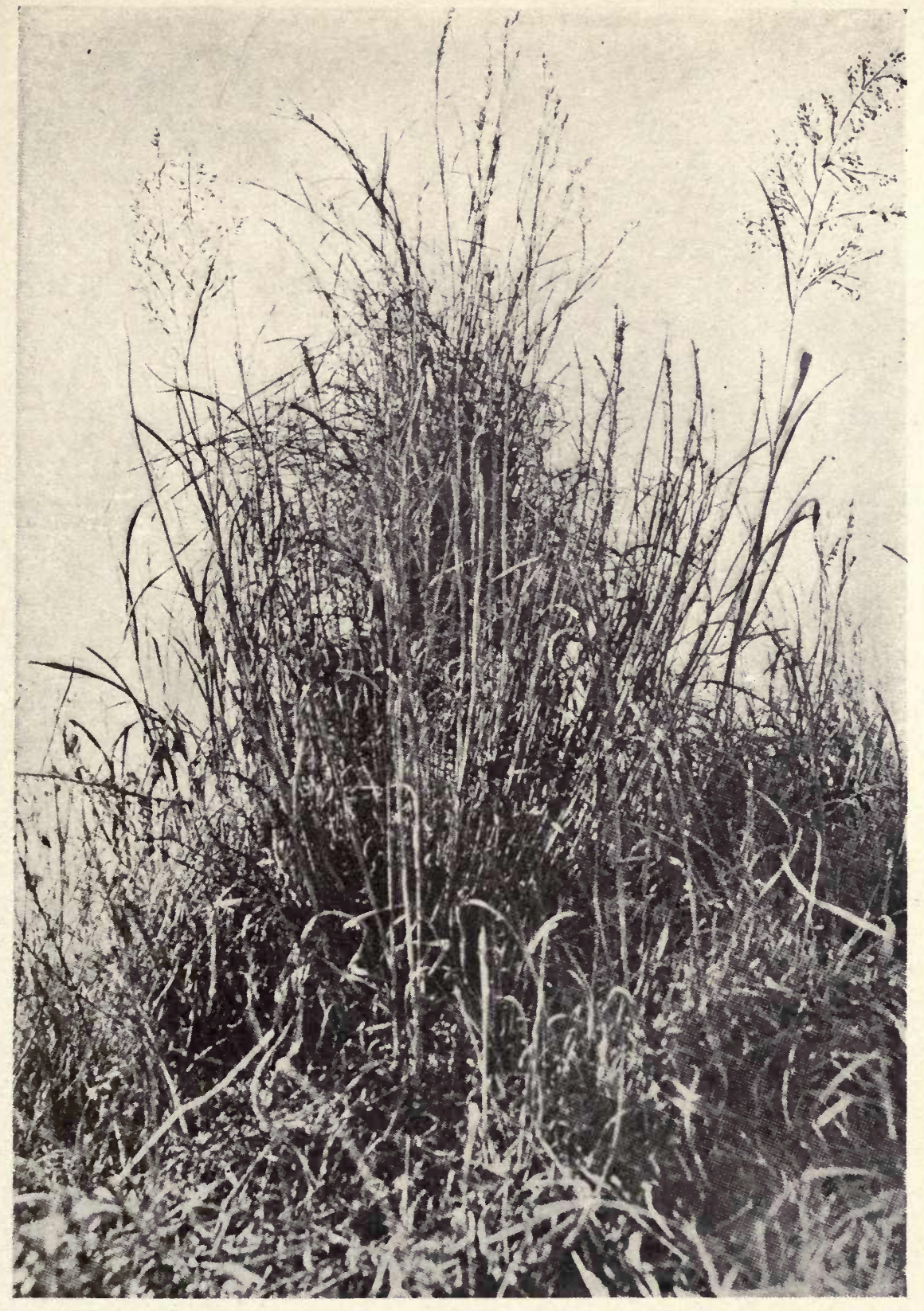

BUNCH GRASS 
$\because \therefore \therefore \quad \because \because 80$

$\therefore \quad \therefore 000000 \% \vdots \therefore \quad \therefore$ 


\section{Surprises of the Prairie}

The prairie grasses are many and beautiful. Every tint of the rainbow is found amid their color glory. Violet, indigo, blue, green, yellow, red-all are there. Tints and mezzo-tints mix and intermingle, blend, and beautify the grasses of the prairie. As pretty as a flower is the yellow bloom of the bluestem. It looks enough like the blossom of maize to be kindred of the corn. The tickle-grass is on the meadow-lands. It is the fern of the prairie, for its fronds are even finer than the fern's. Sometimes its seed-pods are the color of wine, but mostly they are a beautiful sepia, or brown. When ripe and uprooted by autumn winds, you may see the tickle-grass tumble like tufts of feathers across the prairies.
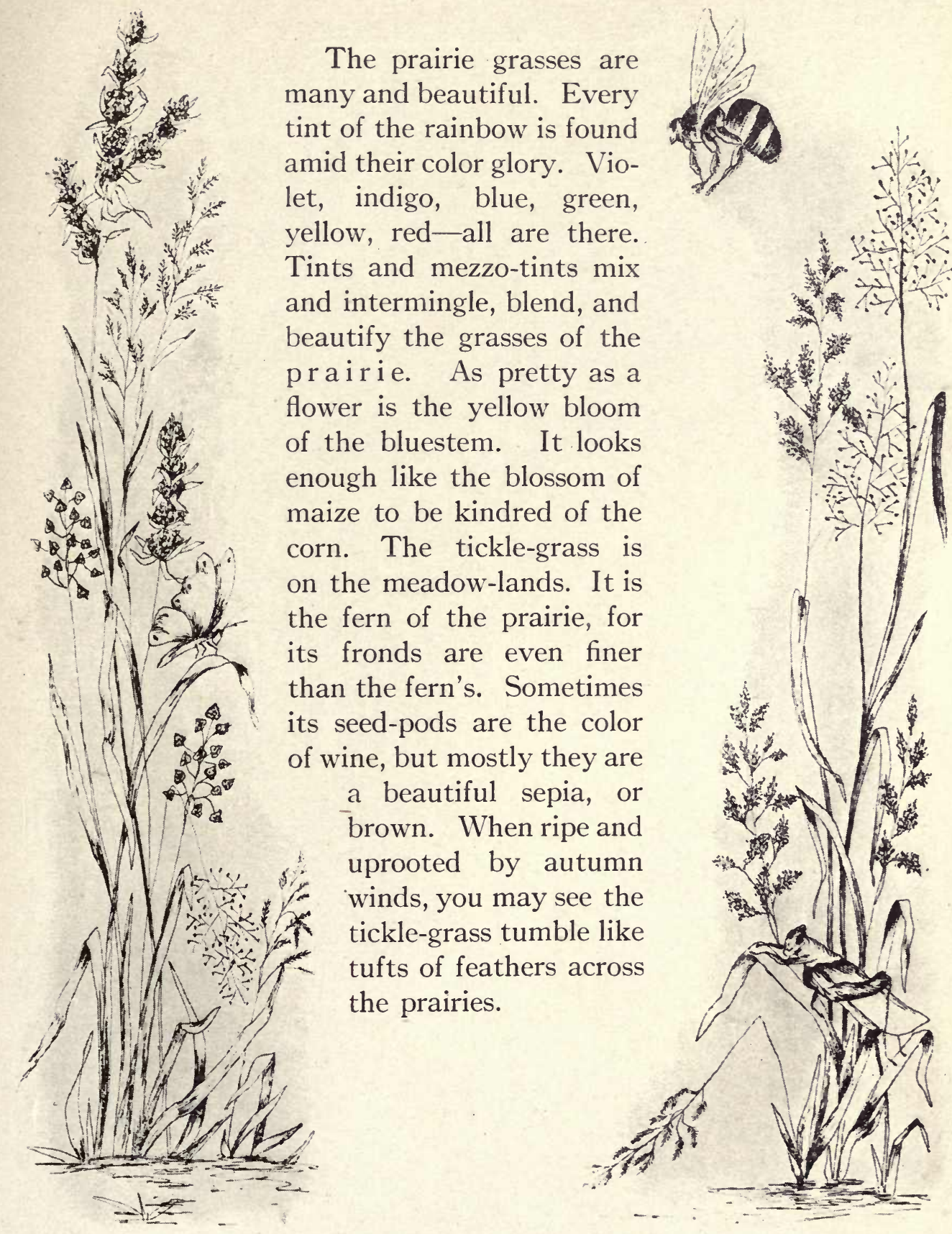


\section{Meadow and Mountain}

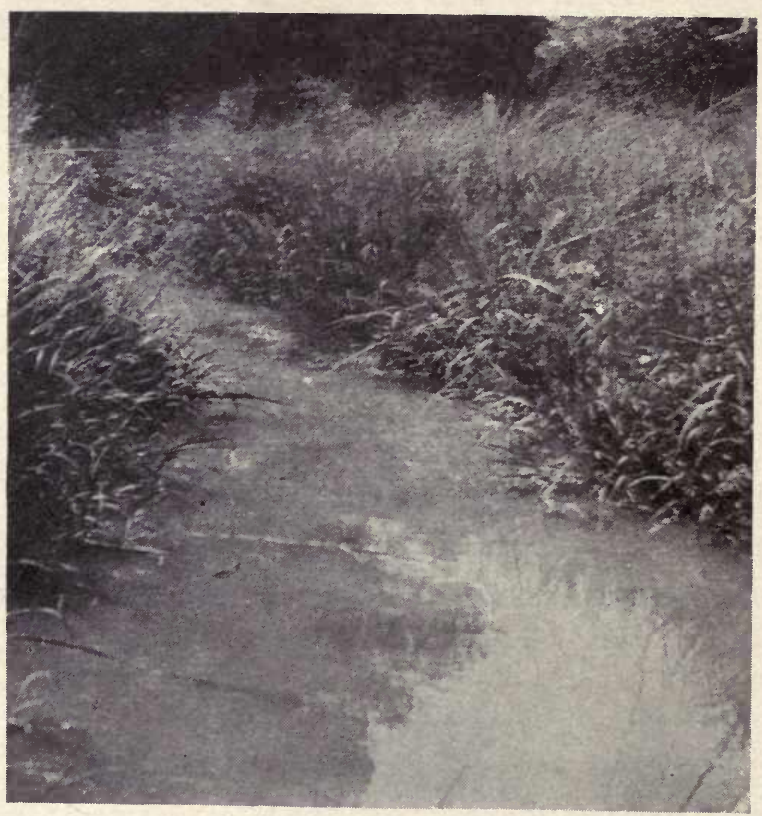

The bunch-grass, the blue-eyed-grass, the knot-grass, the gramma-grass, and the famous Buffalo-grass-all are plants of the Western prairies. Close to the ground the stem of this last is as succulent and sweet as the sugar-cane. Its root runs down to somewhere this side of China. Pitch your tent for a day on the open prairie and hear the wind sing, and whisper, and moan, and sigh among these magic meadows of the grassy wild. 


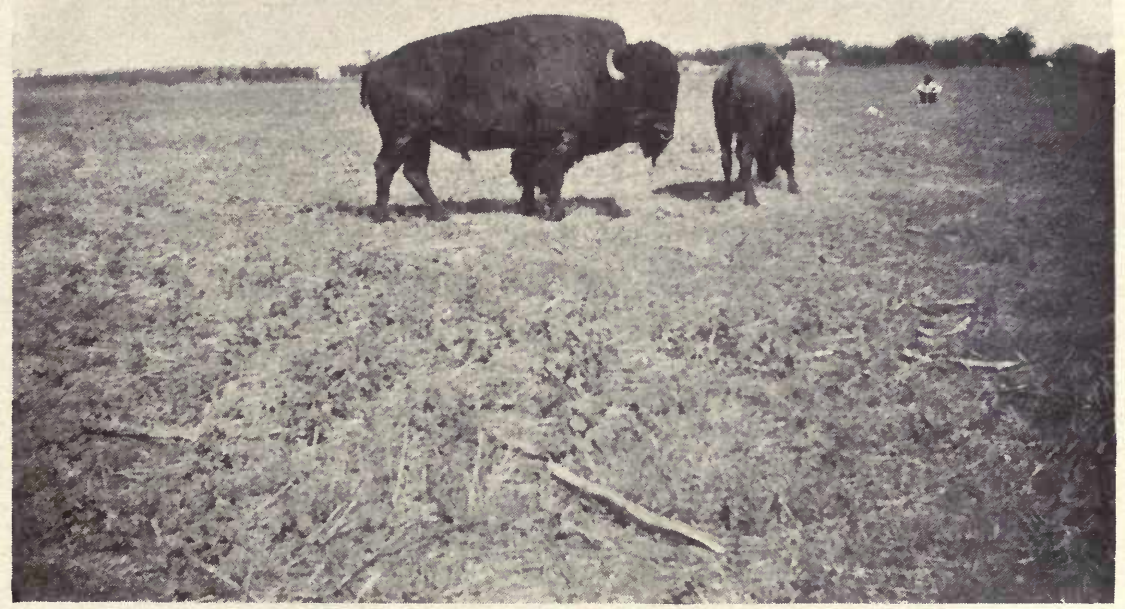

BUFFALO

The American Bison was once the wonder of Western prairies. His shape is not wholly unlike the lion's-large of chest-girth, but tapering toward the tail. His horns are almost semi-circles, a beautiful black curving out on either side of his head, coming toward a common point out from the center of his forehead. They are now among the rare relics of the range. You may yet occasionally pick one out of the prairie grasses of the West. They are often weatherbeaten and unsightly, but if you will oil them and scrape off the cracked and curled-up surface you will be surprised at the beautiful finish and polish of which they are capable. They will be harder than they were on the buffalo's head.

I was told by one of Custer's men that he had seen these animals literally swarm on the Western plains in un- 


\section{Meadow and Mountain}

countable multitudes. He had sat on his horse while soldiering and had seen the huge herds drifting over the range in lines too long for the eye to take in at one look. I have been told by an early pioneer senator of a Western State that the buffalo used to gather about his prairie hut like domestic cattle homing in the evening for water or food. Many of them were slaughtered for sport, some for food, and many for their valuable pelts. The rapacity of man has plundered the West of this wonder. The buffalo's eye is a lense that would surprise the savants of the world. With his majestic bearing and his coat of curly hair, I count him as a beast of beauty.

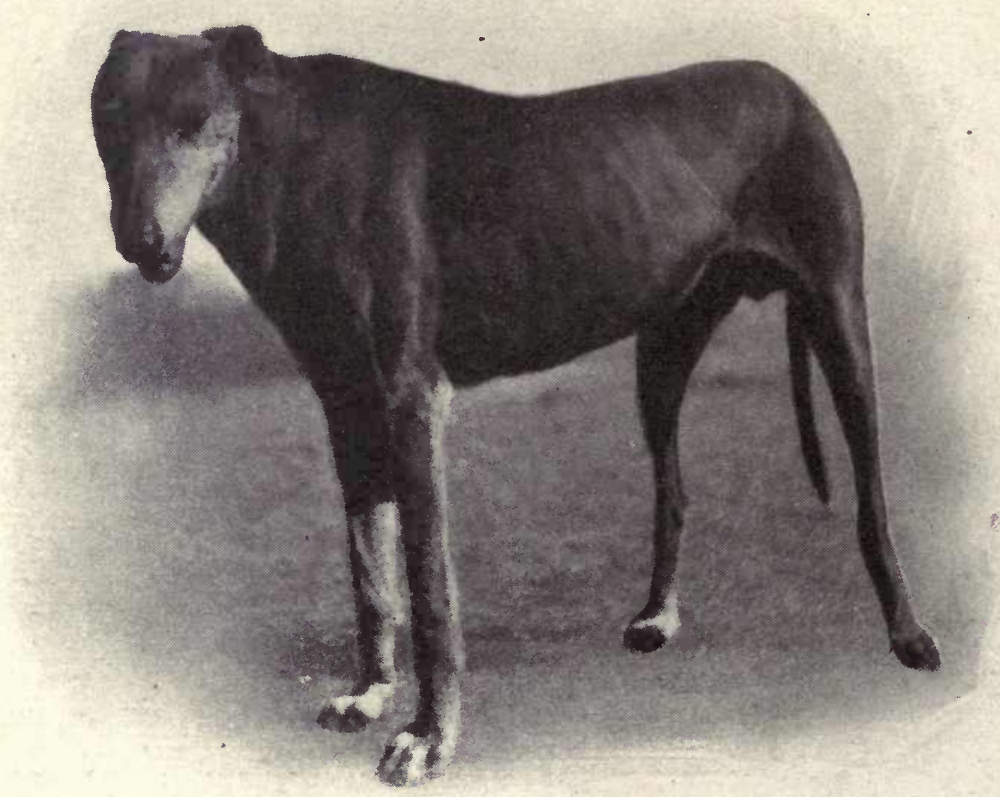

THE RACER OF THE RANGE 


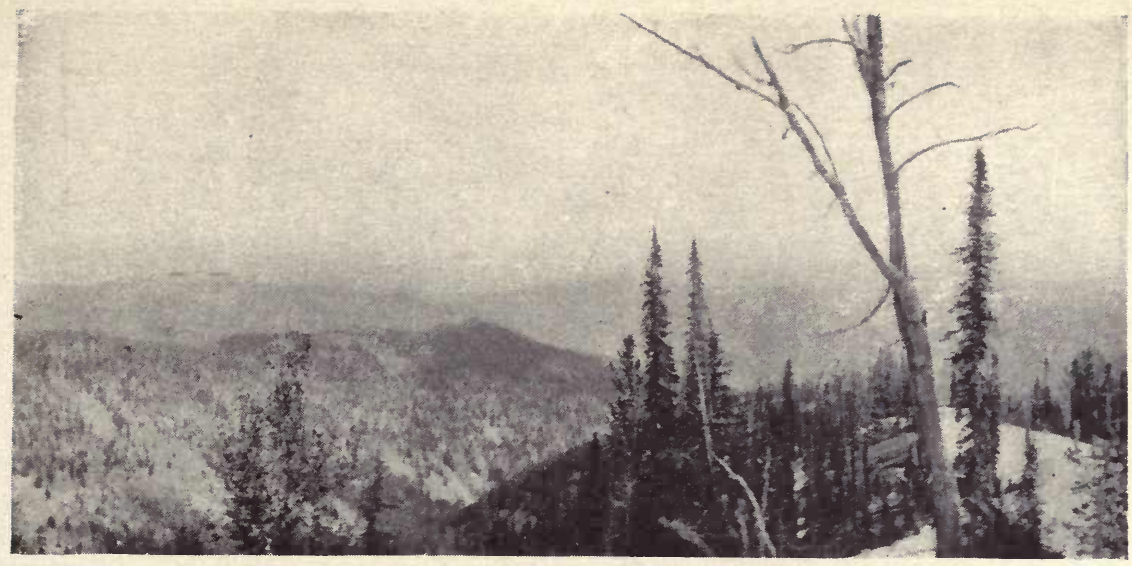

In the midst of a wide range of Western prairie may be seen that which, from afar, looks like a row of weeds. They are, in fact, the tops of tall wild cedars towering over a deep cañon. The floods of the centuries have furrowed the prairies. At the head of this cañon was a delicious spring trickling among the red roots of the cedars. All around this watersource wild turkeys and deer had left their footprints. Coyotes, badgers, and other wild things stole through the moonlit silence to slake their thirst.

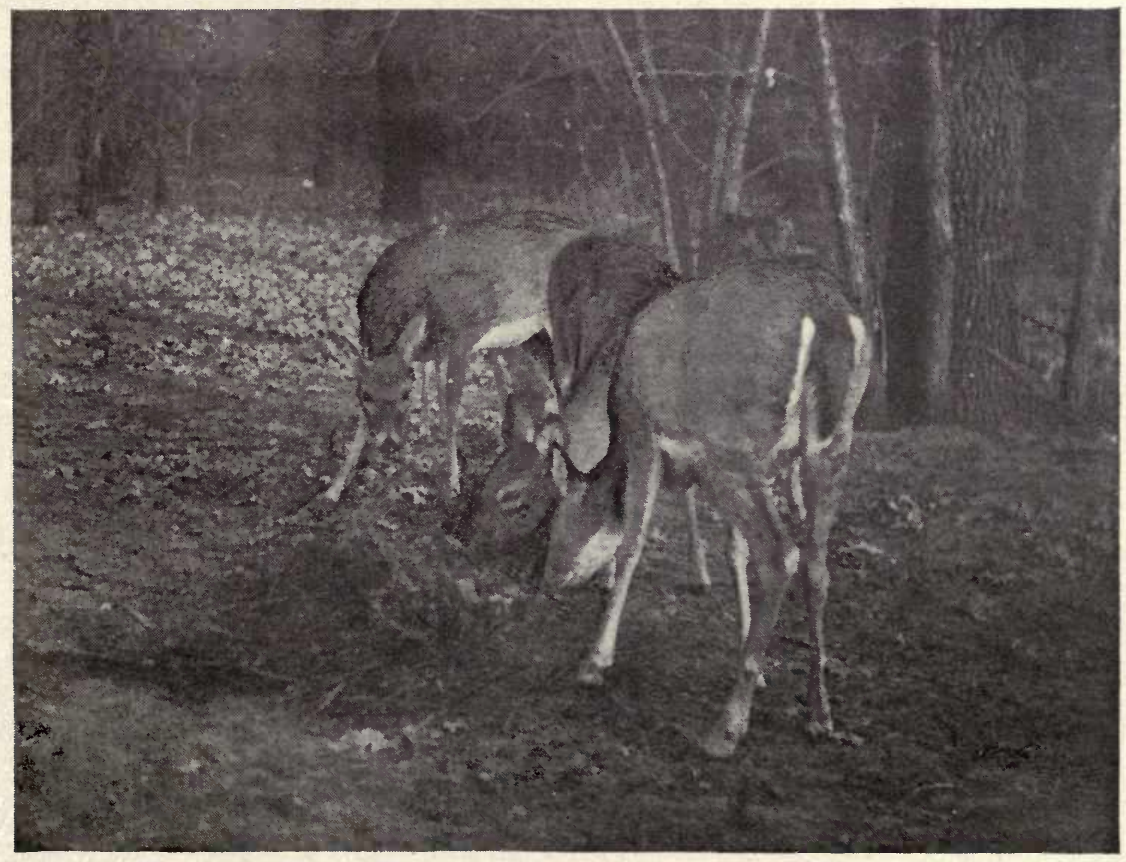




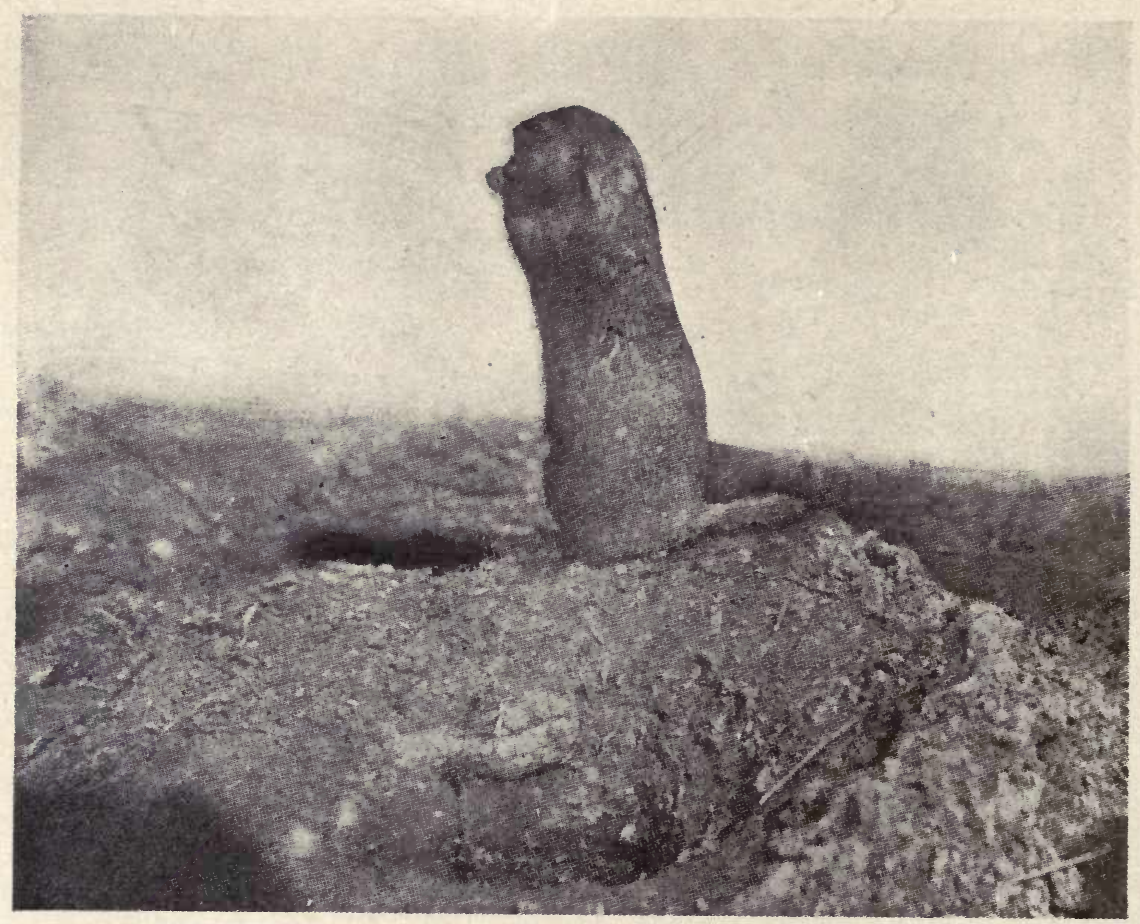

\section{THE PRAIRIE DOG}

How sportive and glad is this dog of the grass, Playing his pranks as the solemn winds pass; Or he signals the flag of his short, stubby tail, While beating retreat at the edge of the trail, And his chattering call. sounds swift on the air As he flings back a challenge from the door of his lair. 


\section{Surprises of the Prairie}

Prairie dog towns are numerous on the broad Western stretches of meadowland. As they sit on their hind legs on the mound about their burrow they eye the passerby with quaint inquisitiveness. Fair warning is given by sharp little barks, each note emphasized with funny quirks of the tail. If any save a long-range inspection is attempted, the wary elders and all the diminutive babies are out of sight like a flash. Its inveterate foe, the weasel, must watch till one is found far from a burrow to secure a juicy feast.

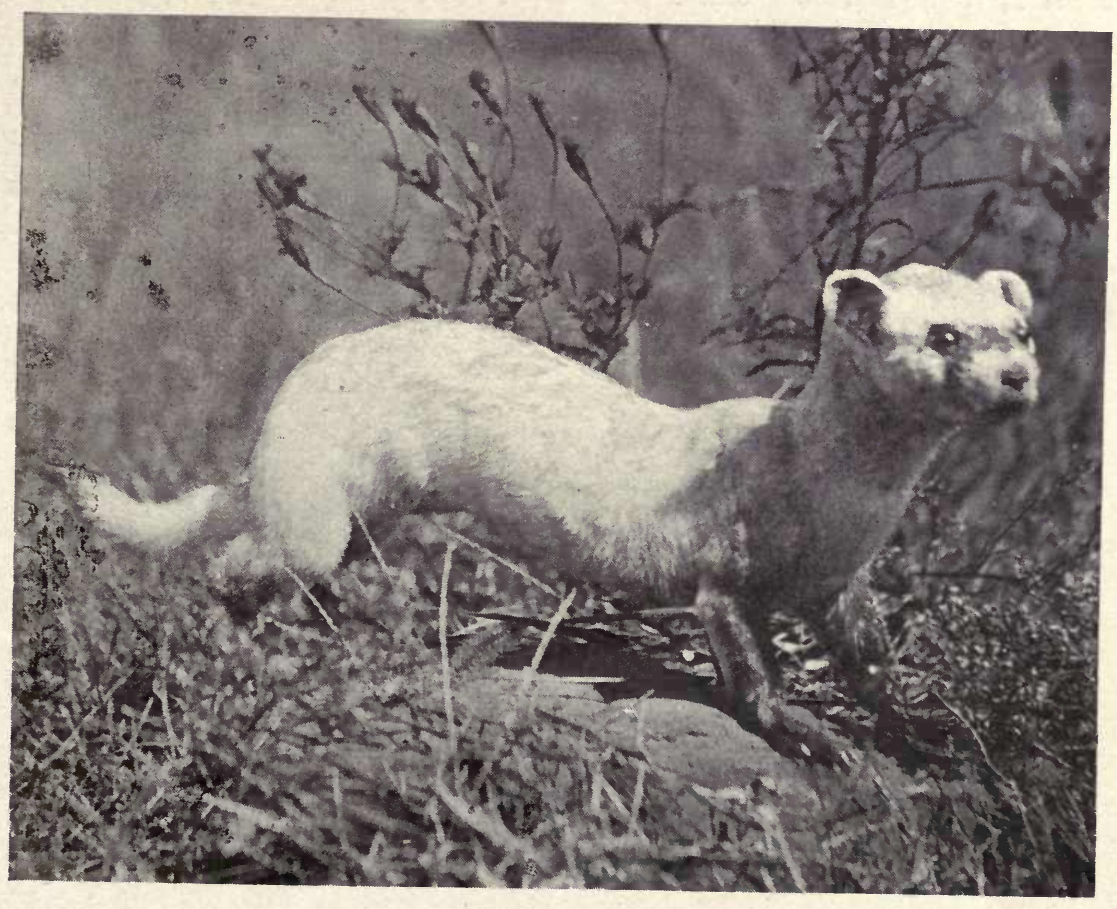




\section{Meadow and Mountain}

A lone tepee on the prairie is worth your while to see. The Indian family within are happy in their home. Some signs of their own adornments may be seen, but these have largely been displaced by the conventional stripe and check of the white man's civilization. But these are not the only checks that the white man has put on his tawny brother. We must also believe that he has helped him forward some. As to the native inventions of our brother in red, it must be conceded that he (or she) has produced some beautiful things. Many of their beads, bows, blankets, baskets, and ornamented sandals are things of beauty. In some quarters it is noticeable now on the white man's wares that he has caught a hint or two from these people of the wild.

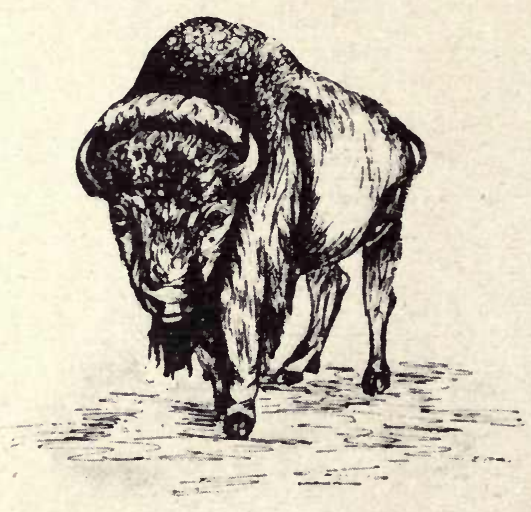




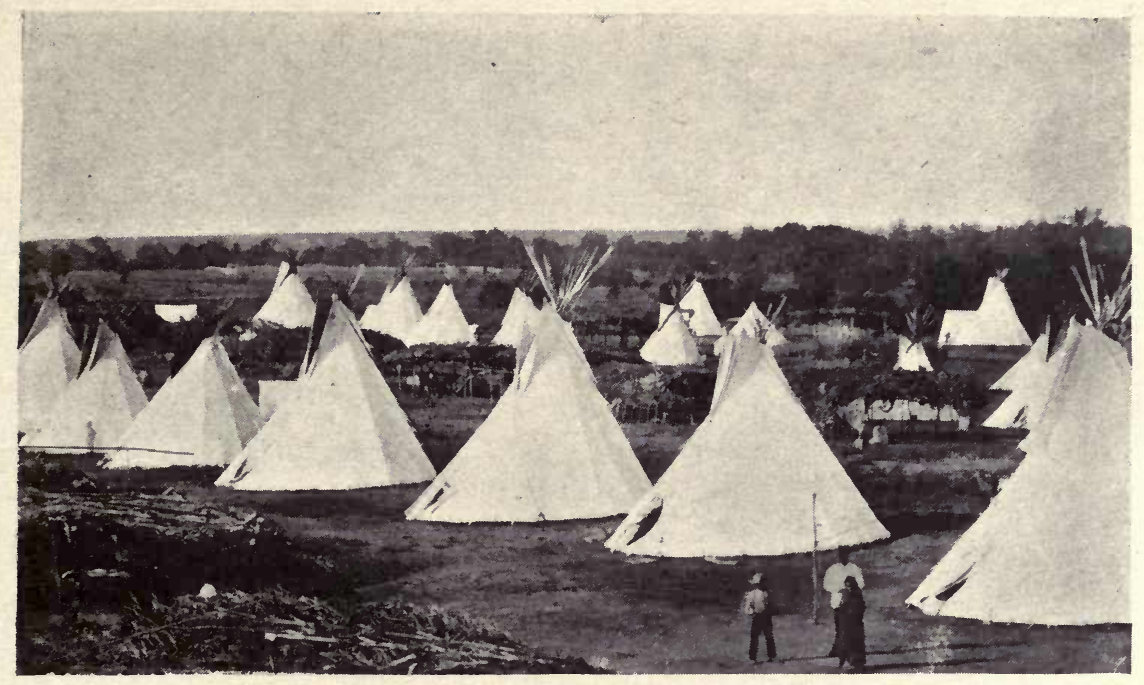

TENTING ON THE PRAIRIE

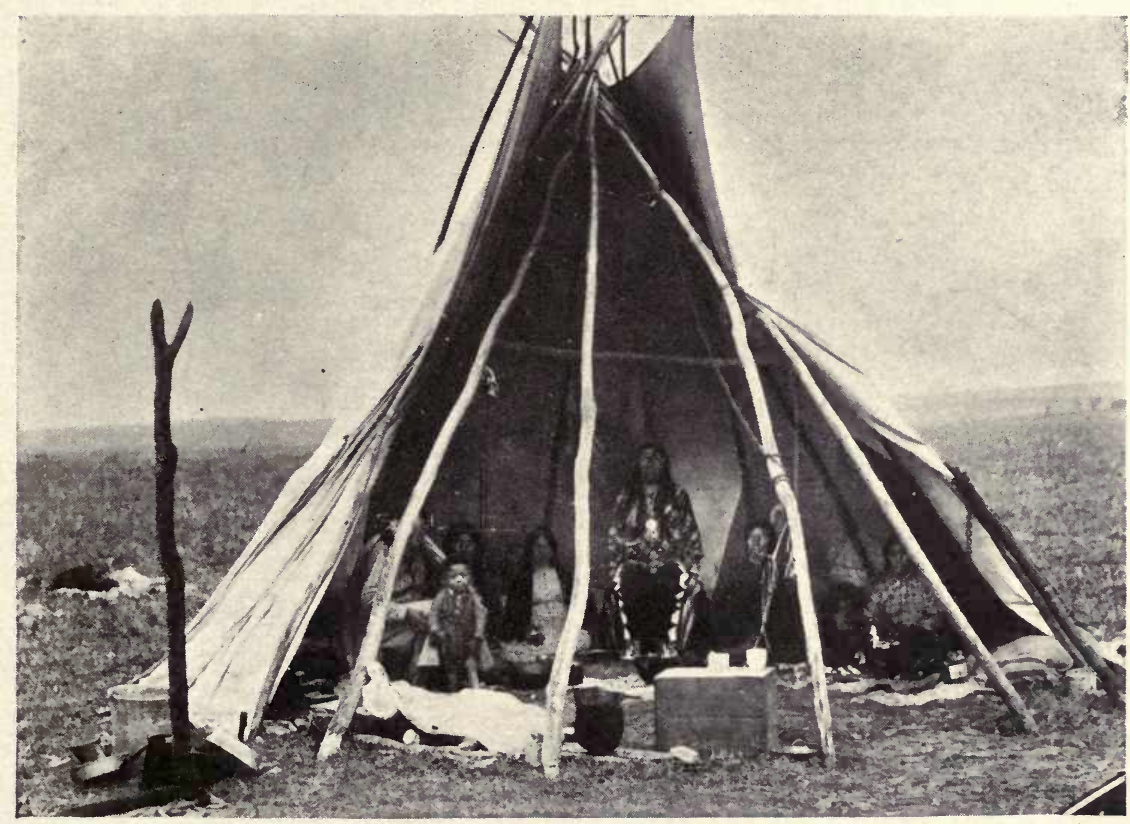

"A LONE TEPEE" 


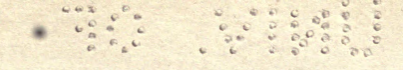

$\therefore \vdots \vdots \therefore 0^{\circ} 0^{\circ} \because \because \vdots \vdots \therefore 0^{\circ} \circ$ 

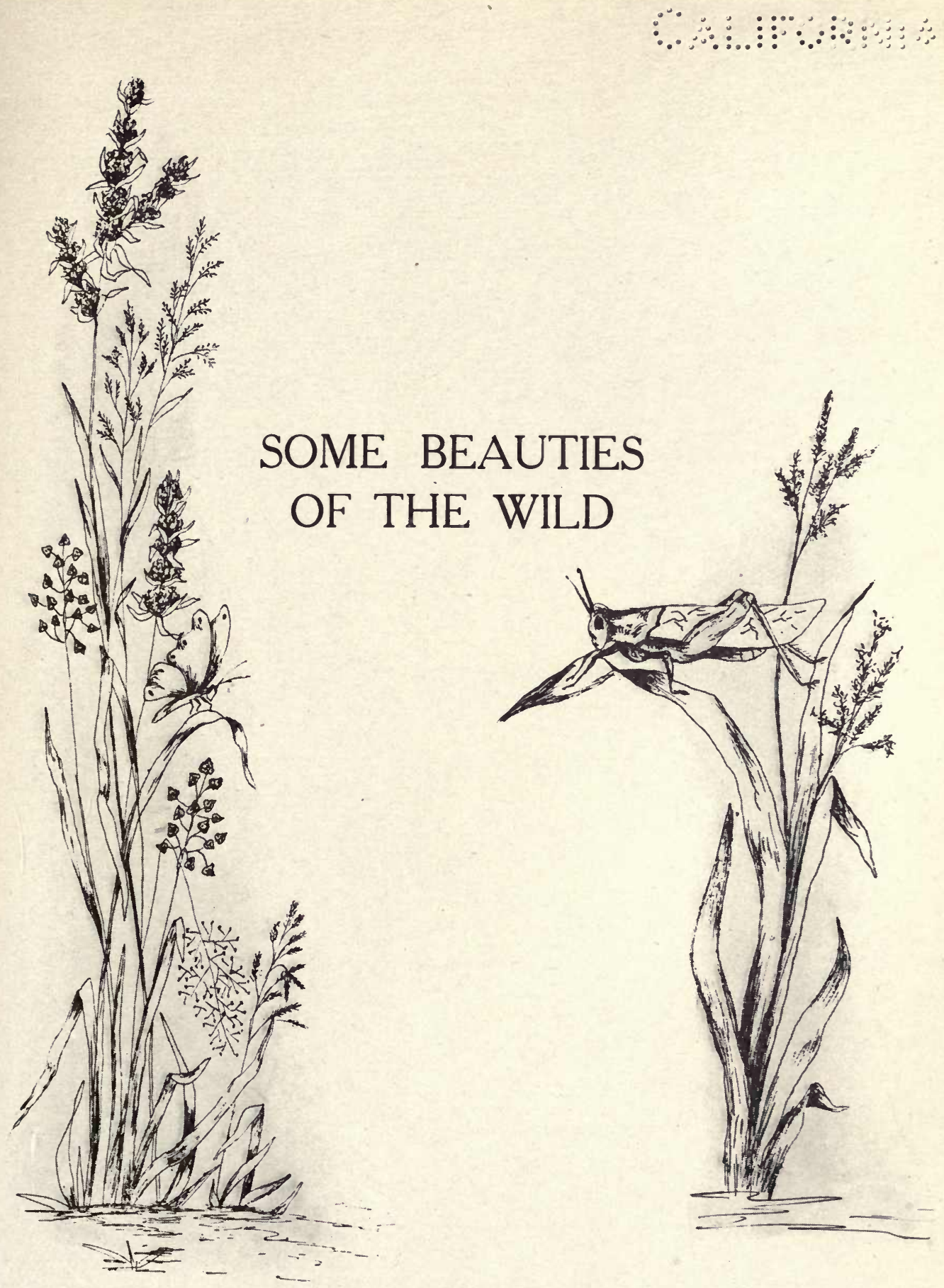



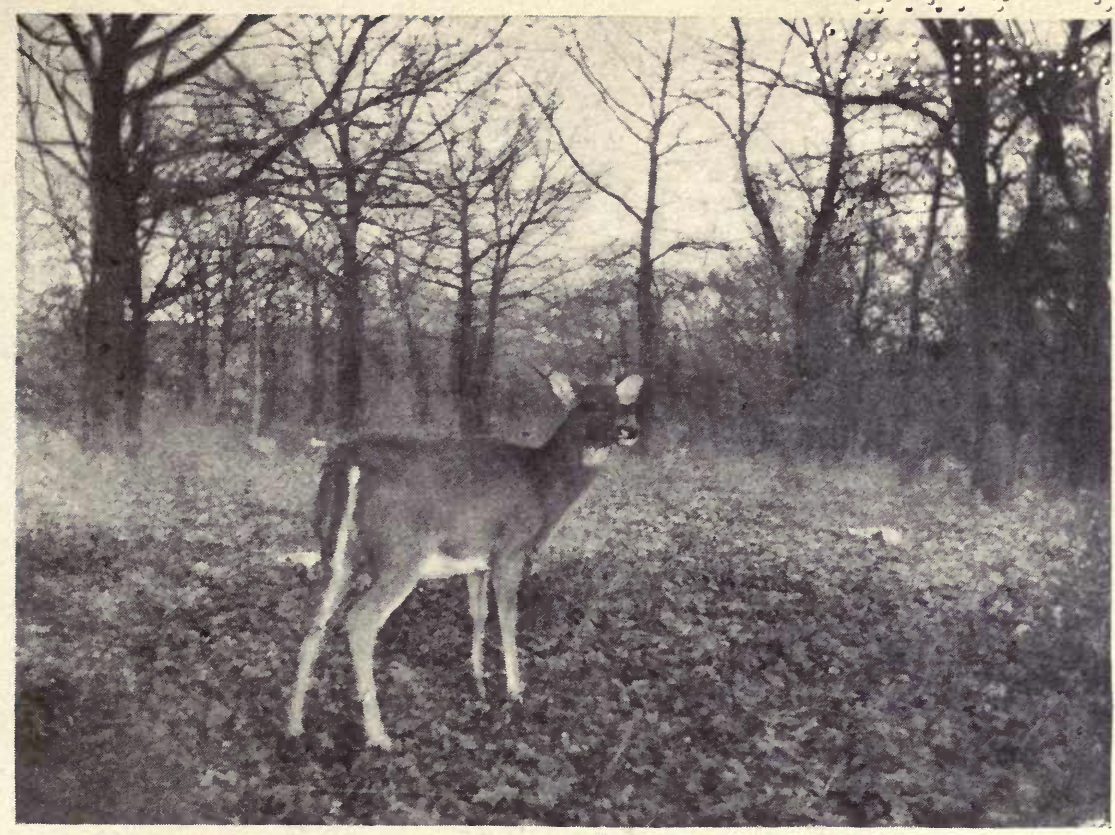

\section{DEER}

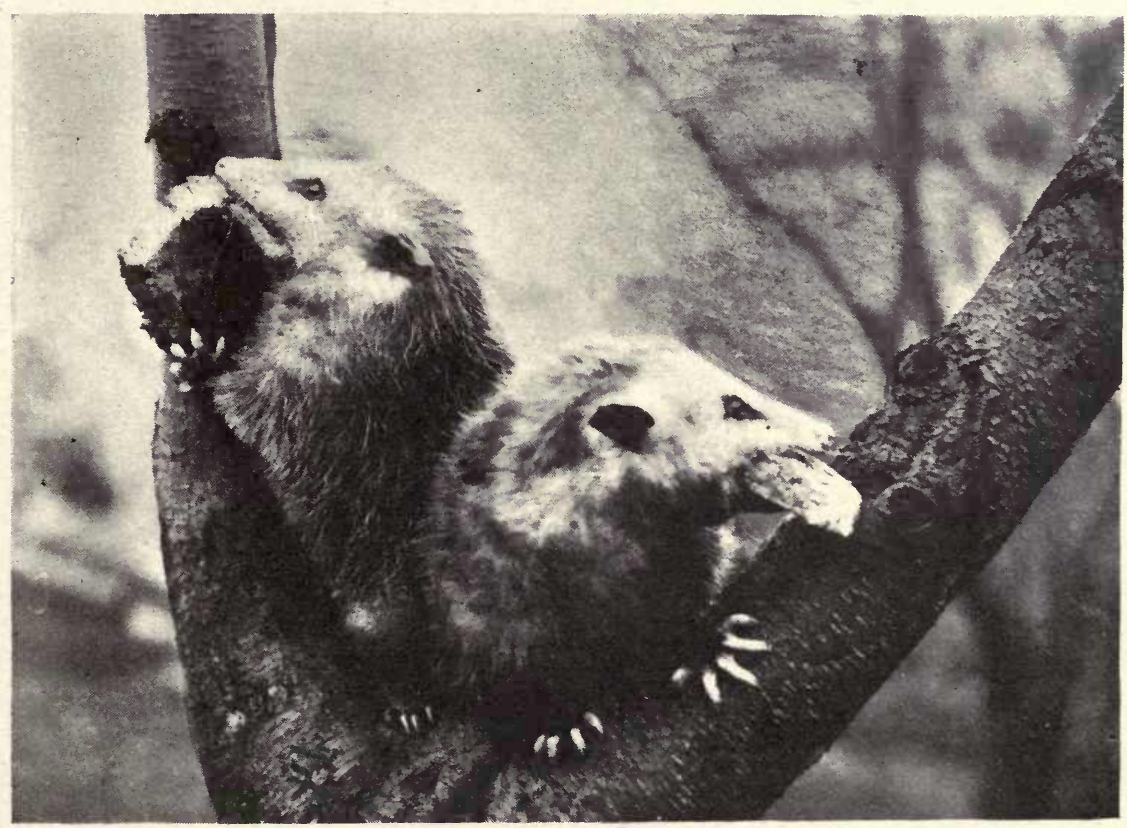




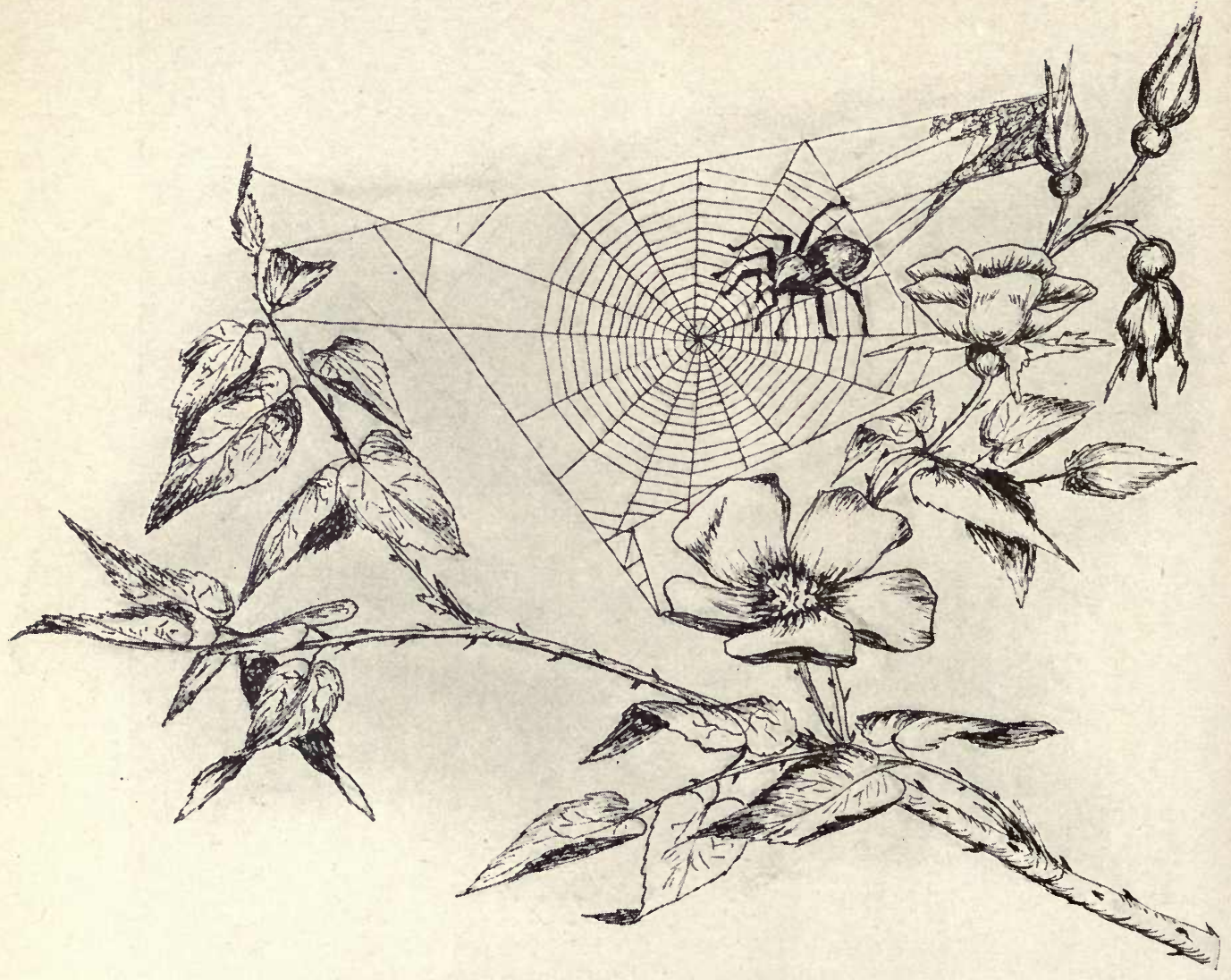

THE SWINGING LAMPS OF DAWN 


\section{THE SWINGING LAMPS OF DAWN}

NeAR the threshold of my home

A cunning foe had strayed, And on a rose tree in the loam

A wondrous thing he made;

Under cover of the night

He built a silken gin, And at the dawn of morning light

Bade all the homeless in.

His shining cords were stretched with skill,

And woven with such grace

That none would dream he meant to kill

In such a royal place.

The beauty of his bright bazar

No one could ever fear;

Its mirrors caught the morning star

That twinkled crystal clear.

The swinging lamps were globes of dew

Enkindled by the dawn,

And when the morning breezes blew

Across the lighted lawn,

The glowing lamps swung to and fro,

Delighting every eye,

Till dressed in gowns of light aglow

Was every flower and fly.

But when the lights began to wane,

As sea-tides slowly ebb,

I heard the plaintive notes of pain

Soft stealing from a web;

And, as my cautious feet drew nigh,

I heard the dying song

Of one bewildered, foolish fly

That watched the web too long. 


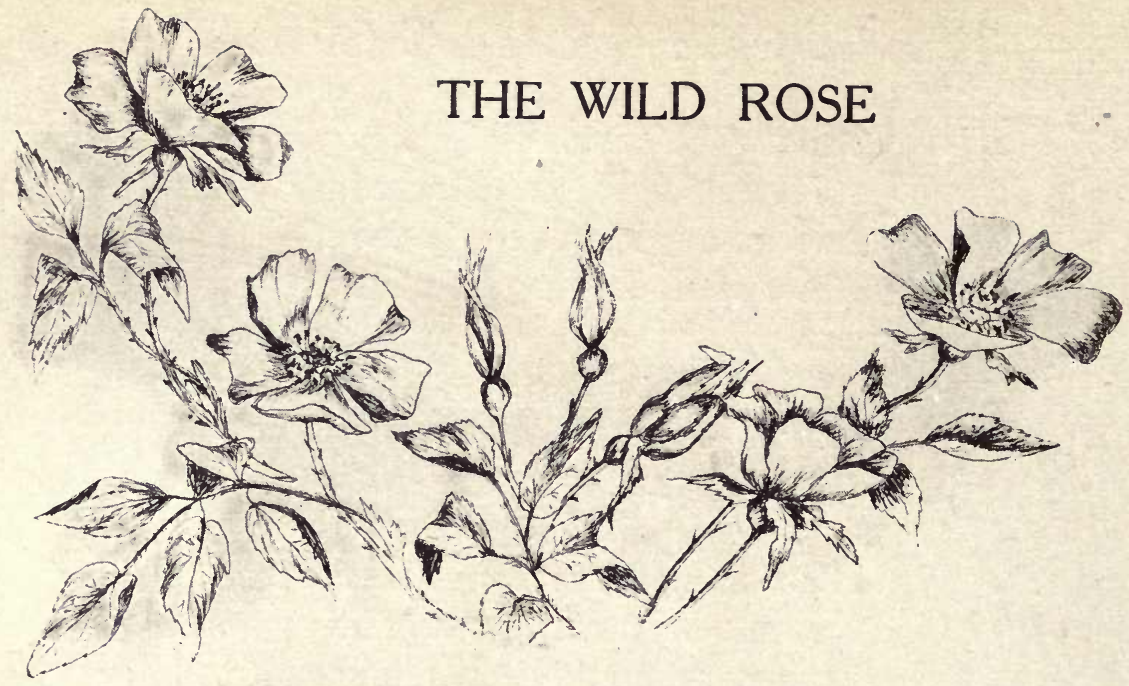

Sweet wild rose among the grasses,

Playing with each breeze that passes,

On thy soft and fragrant breast

Pilgrim bees delight to rest;

Thy pink lips and virgin tresses

Hold more beauty than man guesses,

And there come with thy glad kisses

To my soul a thousand blisses.

Careless beauty in the sod,

Blooming at the feet of God,

Christened with the crystal dew

Angels must have tinted you;

Skillful hands thy robes prepare,

Spun from soil and sun and air-

Bridal beauty of the lea,

Come, sweet rose, and live with me.

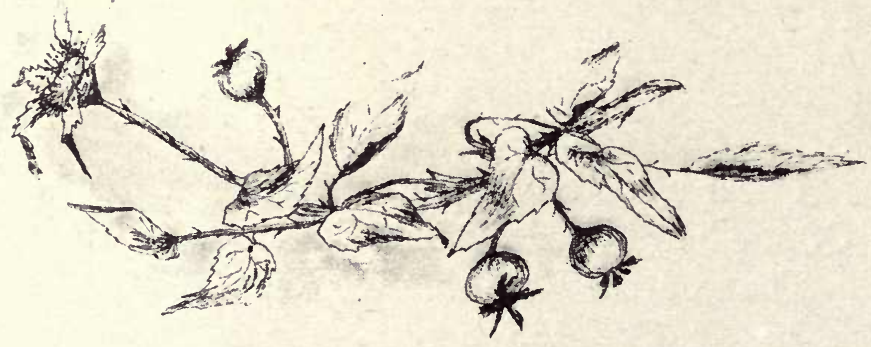




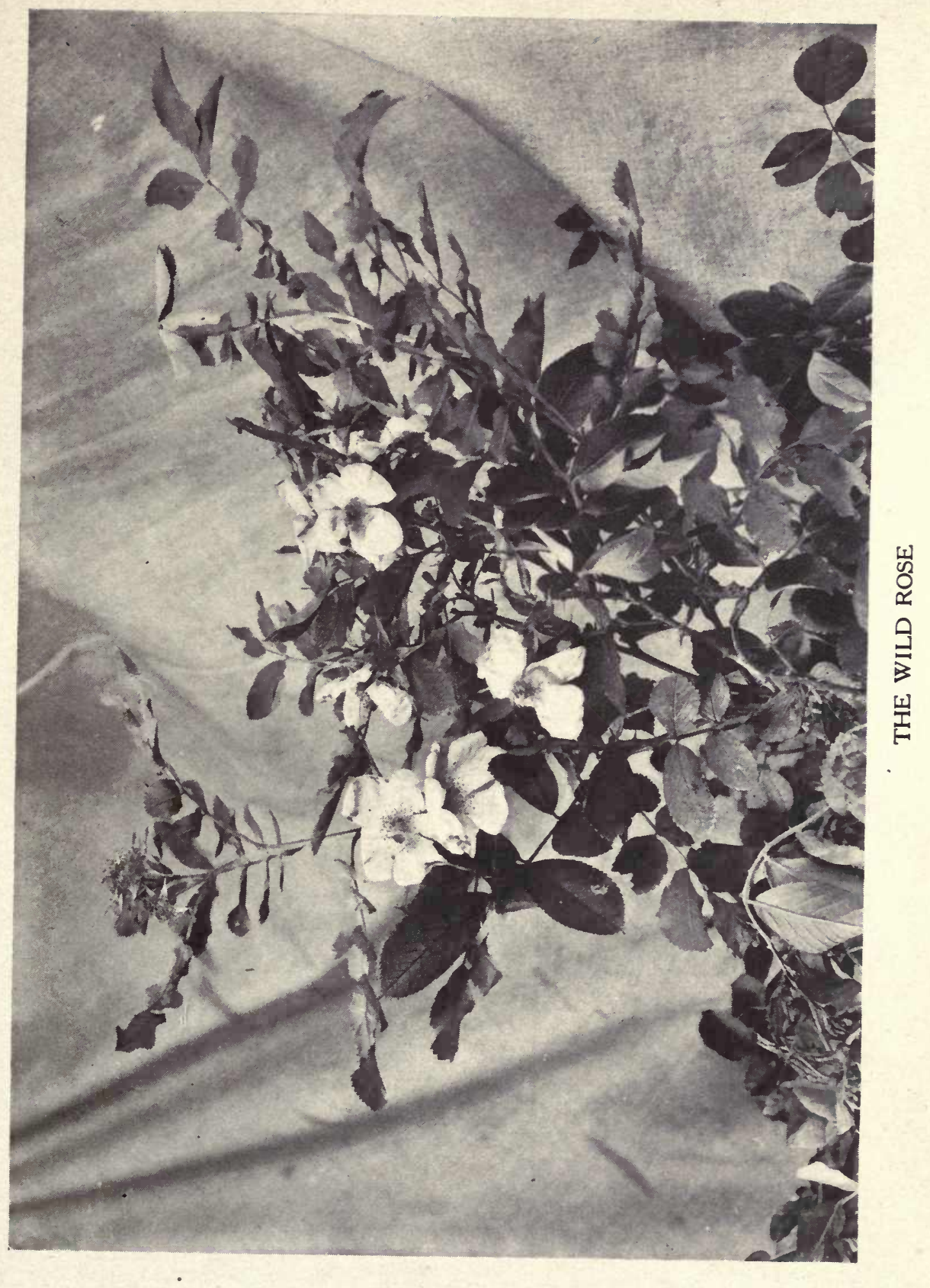




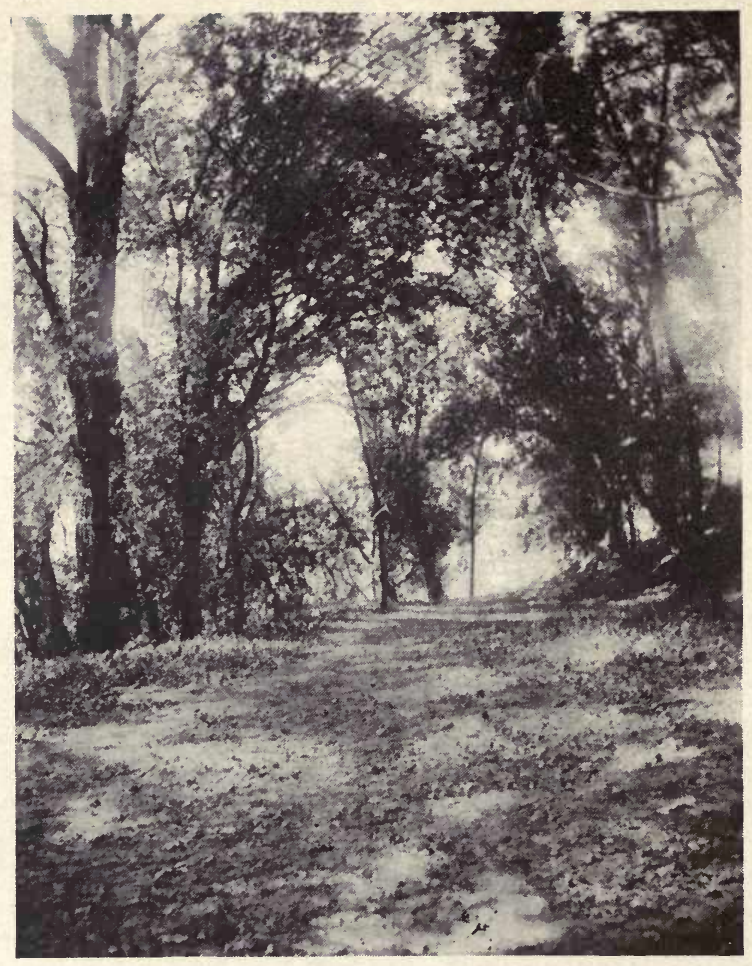

\section{THE VINE-TANGLE}

Life sometimes a tangle seems, In our waking or our dreams; Like the vine from treetops torn By the warring winds in scorn, While the faded leaves complain, Burden-bowed with winter rain; Twined and gnarled in spiral lines, Droop the storm-disheveled vines; Stealing through the falling rain Comes a soft and sweet refrainSinging what, I scarcely knew"Beauty weaves the tangle, too!" 


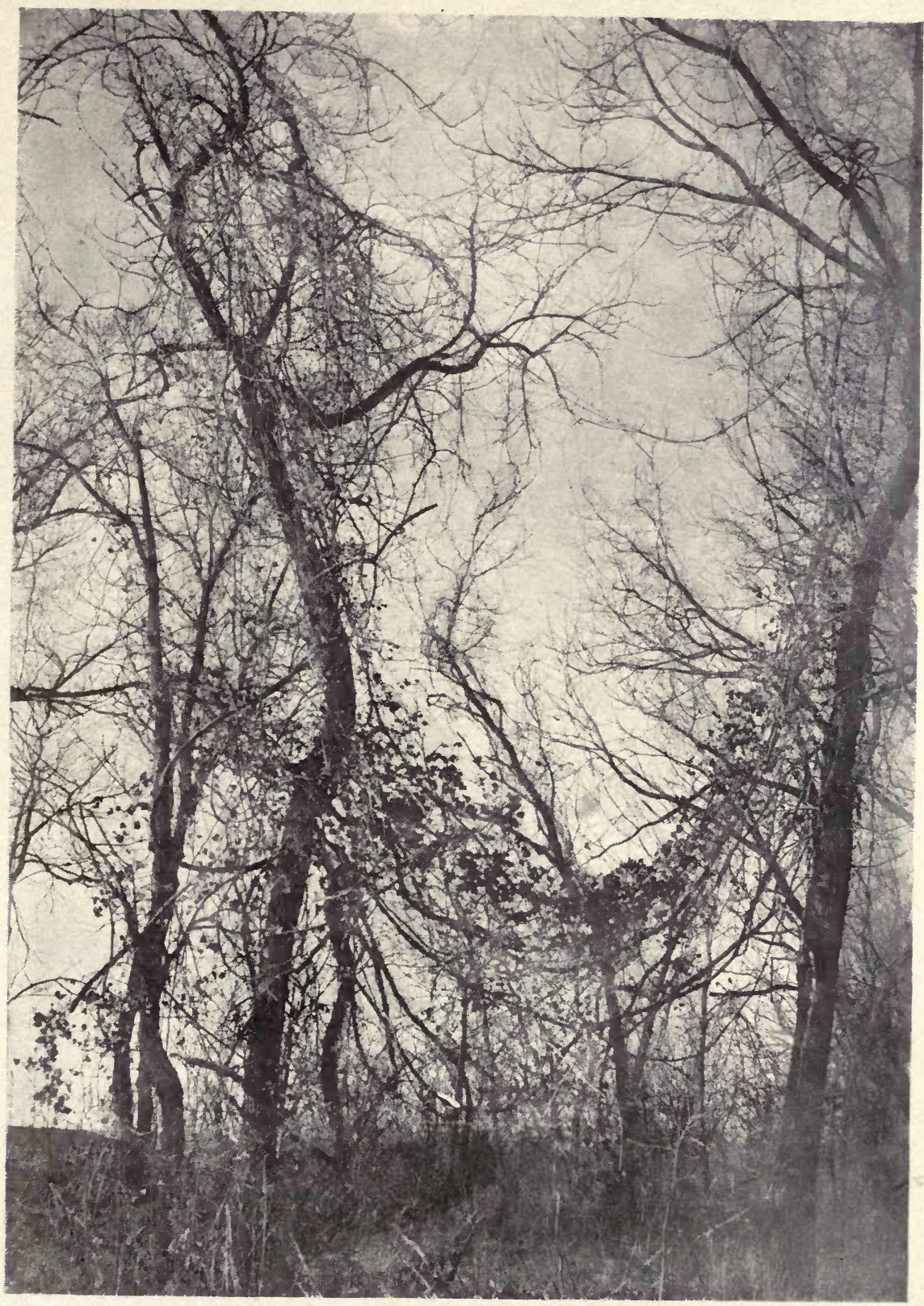

"DROOP THE STORM-DISHEVELED VINES" 


\section{WILD VERBENA}

April showers fall on thee, Thrilling with their minstrelsy, Singing drops from rhythmic clouds, Till thy blossoms come in crowds, And thy ruffled leaves of green Stand about, thy stem to screenFence thee with a leafy mail From the pelting springtime hail; Wild verbena, crowned with pink, If such glory thou canst drink From the vital stream that shoots Through thy frail earth-covered roots, Let some living current surge Through my soul, and sweetly purge Its earthly dross, that I may know How the hidden man may grow, Surely rooted in the deeps Of the heart of life that keeps Beauty close in touch with God, In the soul or in the sod. 


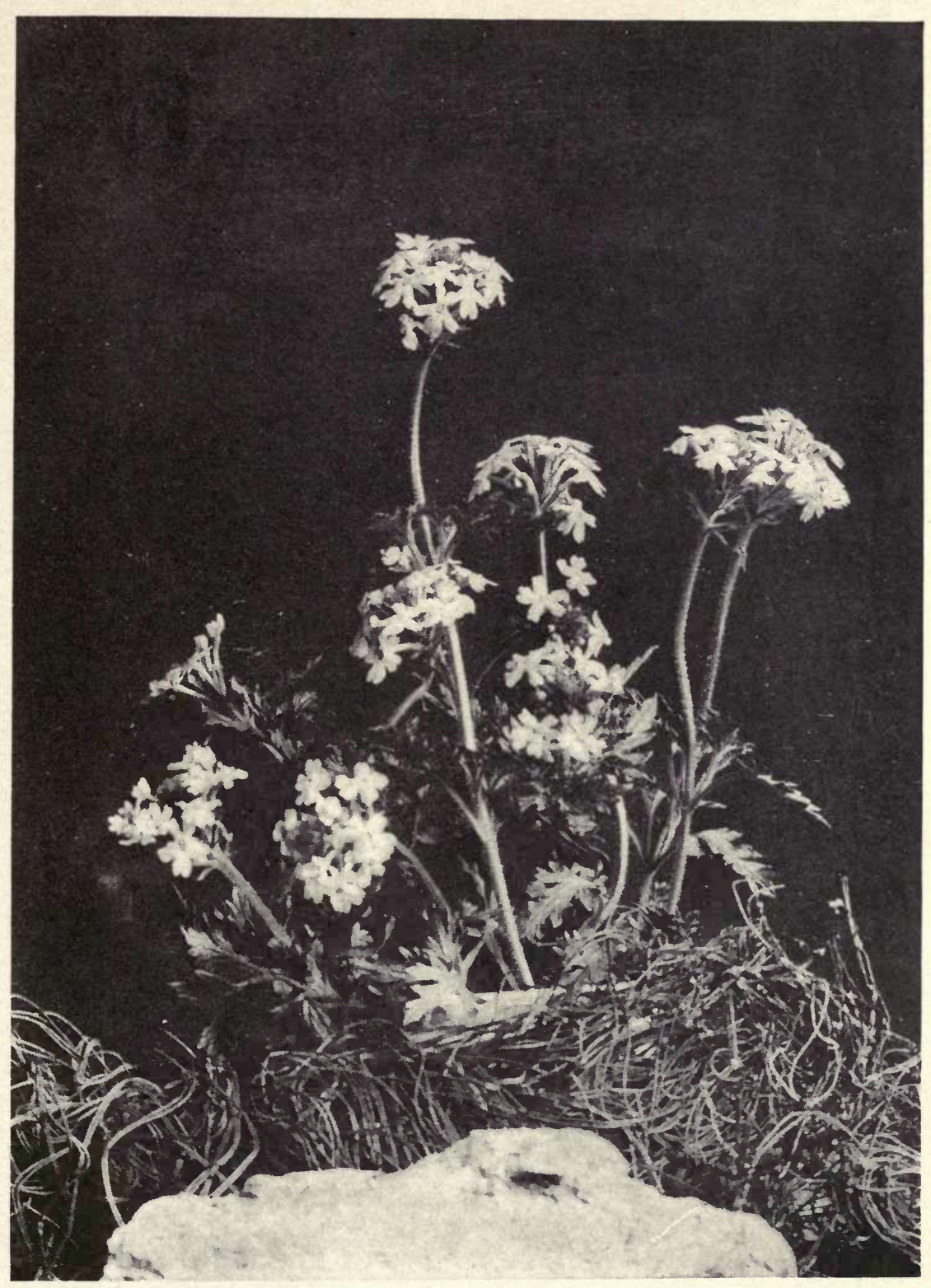

THE WILD VERBENA 


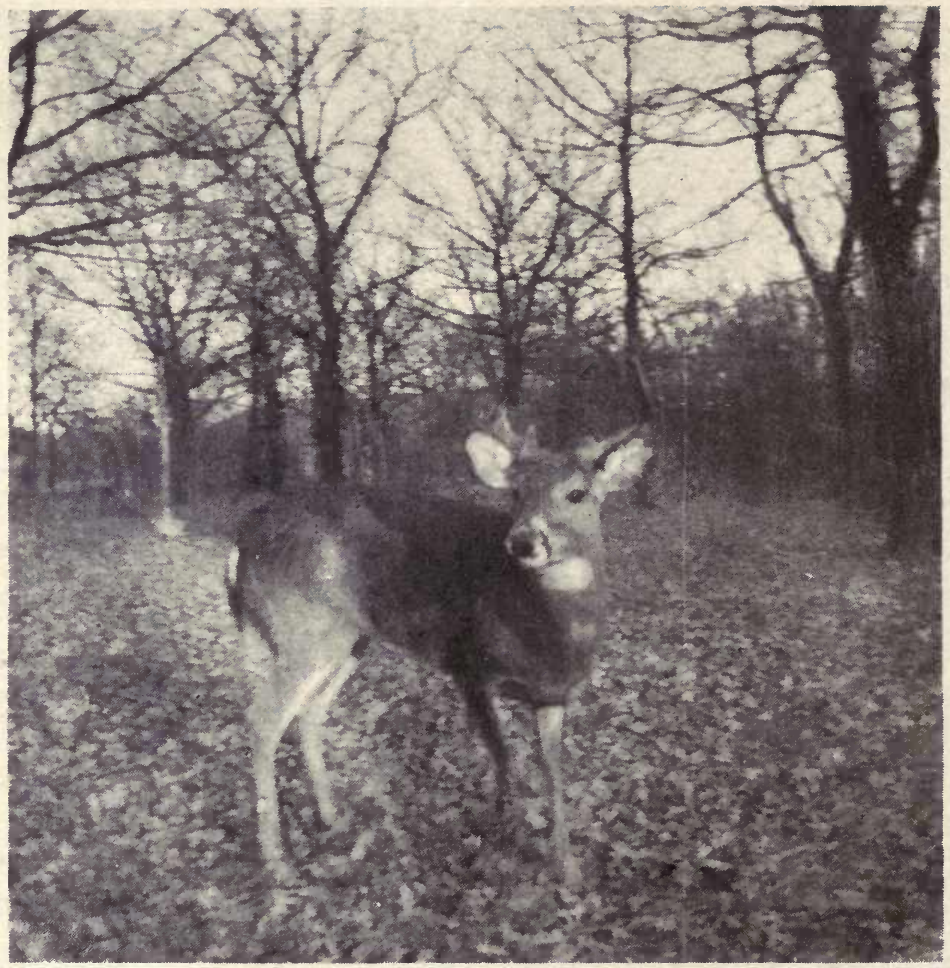

\section{THE PRAIRIE “DEER APPLE”}

Pink bunches of beauty, half-hid in the grasses, Whisper good news to the deer as he passes;

Gazelles of the prairies o'er wild wastes straying, Ye may listen and hear a sweet summer voice saying, "When weary and weakened with hunger ye grapple, I lay at your feet, my prairie 'Deer apple."” 


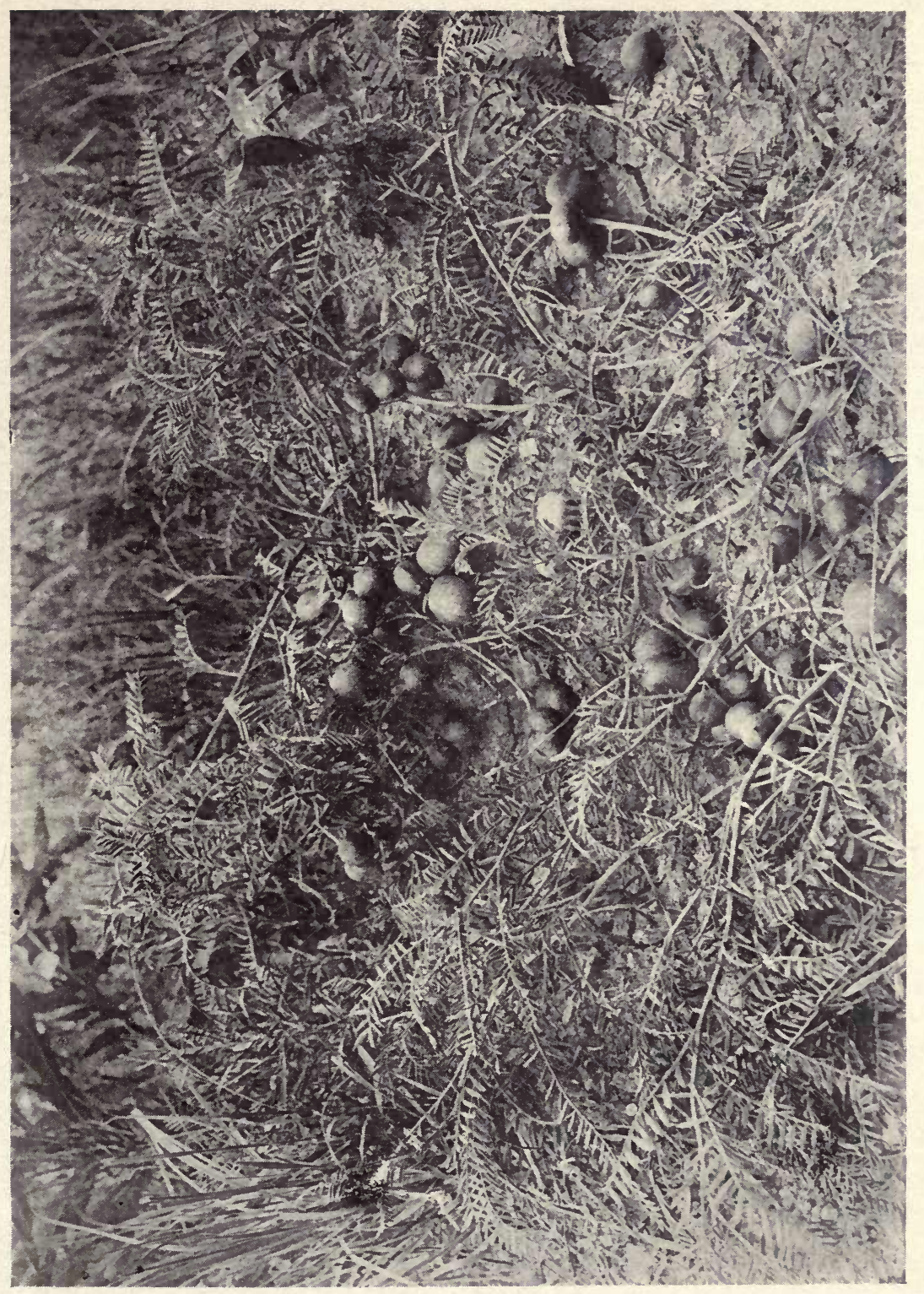




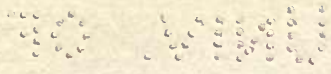

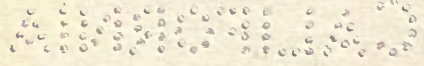




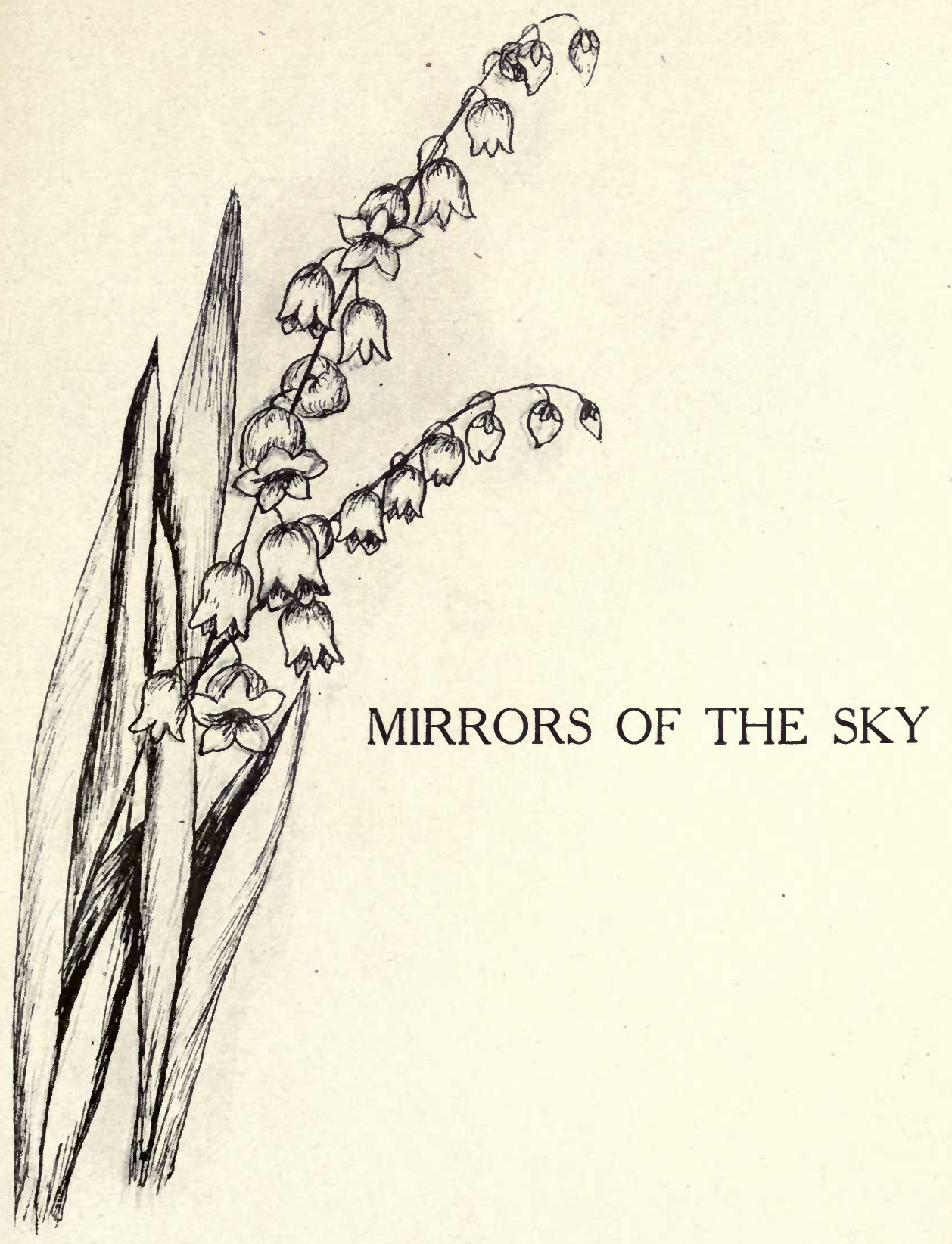



$\because \because \vdots+\because \vdots \vdots \vdots \vdots$

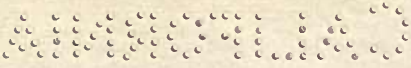




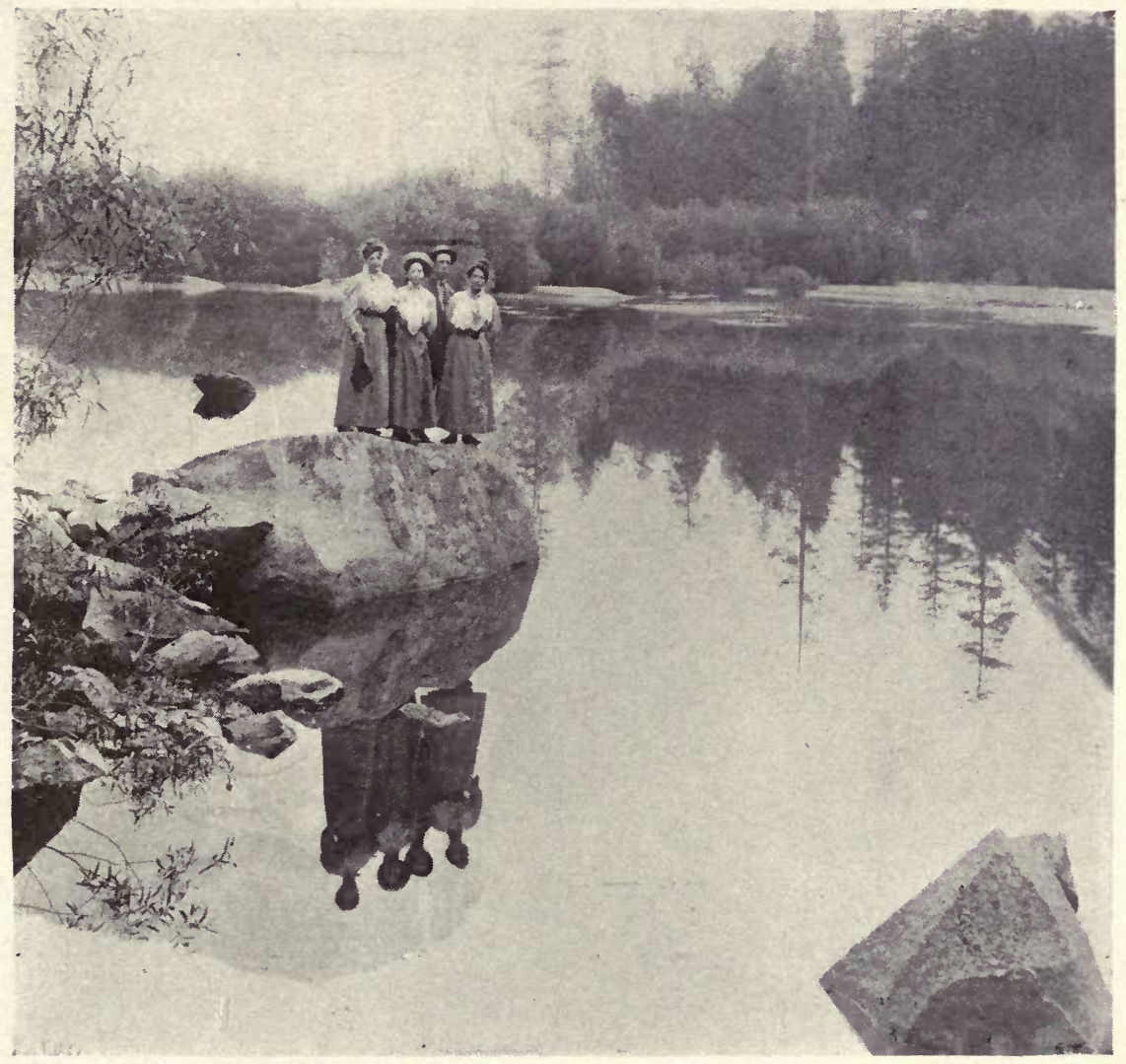

ONE OF NATURE'S MIRRORS 
$\because \because 4 \div \because \because \vdots$

$\therefore \quad \therefore 8 \div$ 


\section{MIRRORS OF THE SKY}

UNDER certain conditions of light and atmosphere, the sky becomes a mirror. It is a common sight on a summer's day in the West and Middle West, and in desert countries as well. The sunlight falls on wide stretches of weather-worn sand, wind-polished pebbles, and dried grasses. These sheets of flame are instantly flashed back into the face of the sky, and, behold! the sky is a marvelous mirror in which the astonished traveler beholds shimmering lakes shot across with sun-glades, or browsing herds, or tall and beautiful trees, or splendid cities with turrets and domes! But the eye can see none of these in reality. It is an optical illusion, not wholly a delusion. The sky must have gotten these pictures which it shows to the traveler from substances somewhere! How far away were the cities? How far away were the herds? How far away were the trees? The substance was somewhere or the shadow could not have been seen, for even a shadow must have adequate cause. This mysterious mirror of the sky is the artistry of God, hung in His blue galleries above the bleaching sands!

It is not at all easy for the inexperienced traveler to believe that there is anything secondary about the mirage. Its appeal is so primary and powerful. It is a real appeal from reality. But it is through the secondary processes of reflection and refraction. A mere nothing could not produce such a delightful and refreshing experience as the mirage produces through the delighted traveler's eyes on a dismal day.

The monotonous miles through desert plains had dragged 


\section{Meadow and Mountain}

away for many long and lonesome hours. The traveler's eyes had been gladdened in other journeys with the sight of tasseling corn and silvering oats and goldening wheat, but now it was sage-brush, cactus, and sand; cactus, sage-brush, and sand; then a short shift to sand, sage-brush, and cactus; and then-and then, sand-sand-sand. What pity that he could not catch sight of the blues and greens and grays and browns and sepias in the sand. It is not straining a point to say that sand is beautiful, only its beauty must be seen. Not only are the colors of the sand beautiful, but many a sand-drift is as shapely as a drift of snow. And the spirals, and circles, and lines in the sand-these are the exquisite artistries of the desert winds. No human artist's carvings could be finer than these curious carvings of the wind. There are wave-lines and pebble-prints and a thousand beauties in the sand. If one really wishes to find the wonder-work of the wind, he will search among the sands.

The traveler's mistake was in letting the old sights shut out the beauty and wonder of the new. He was tired of sand-sand, and nothing but sand. A mud-puddle would have been a welcome relief. He had sighed and shut his eyes and opened them, and sighed again and had wondered, "O Lord, how long?" It was in this dreary mood that he suddenly caught sight of a green field and a grazing herd, and, skirting the field, a lovely, old-fashioned lake. He seemed to be waking from a troubled dream. He gazed and wondered awhile; then, seeing some tall trees in the distance, he broke out delightedly to his companion, "Well, we have reached God's country at last." His friend, from his experience, replied, "That is only a mirage; we are many miles from green fields and herds and lakes and trees." It 


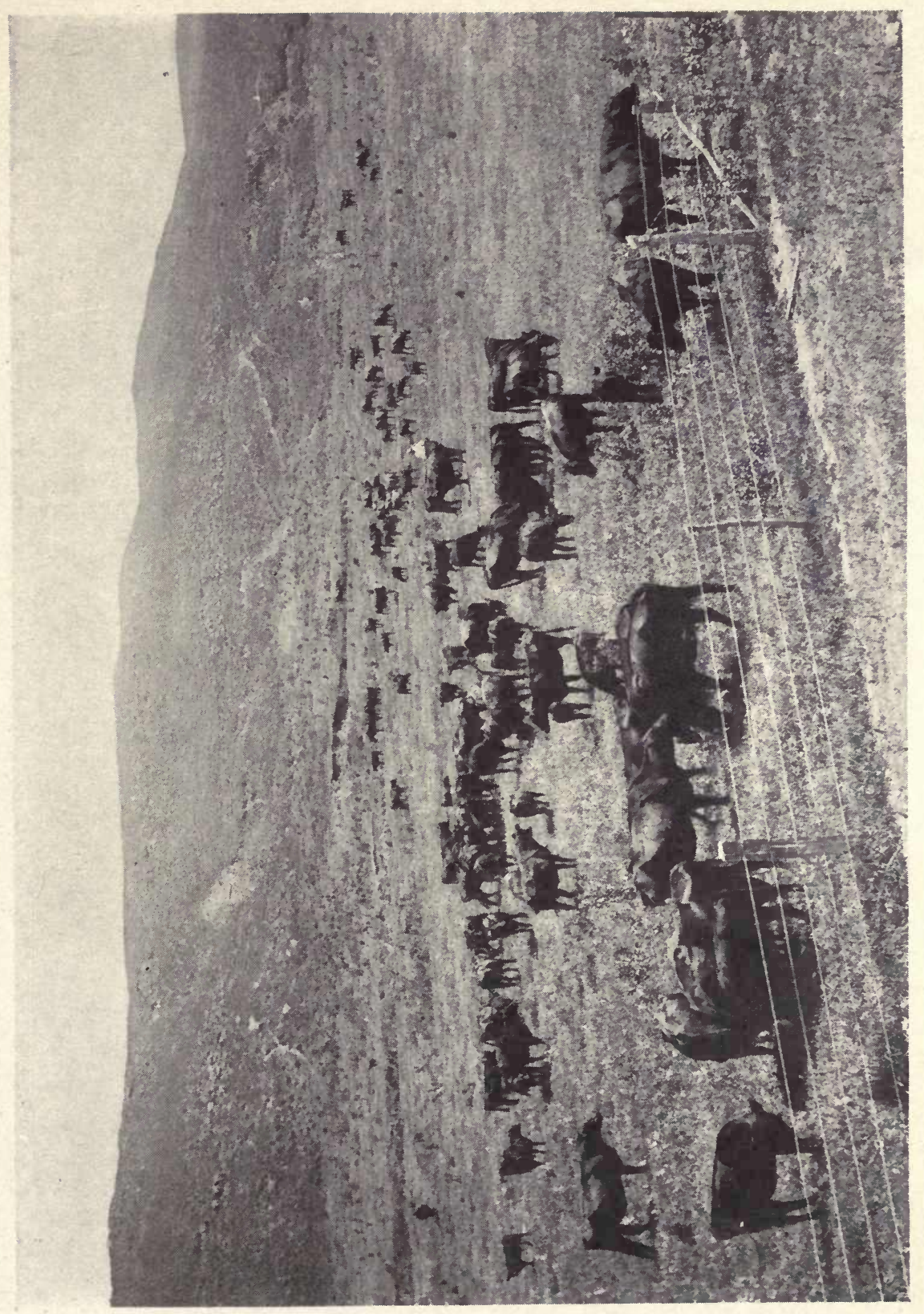

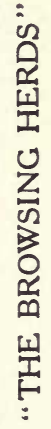


$\because \because \quad 903000^{\circ}$ $\therefore \quad 300000000$ 


\section{Mirrors of the Sky}

took some time to break the bewitching spell that had fallen on the traveler, but it broke, and he collapsed and relapsed. His merry mood vanished at once, for he was not the man to be delighted with an "unreality," even if it was really delightful. But how foolish of this good man to dismiss his delight! He ought to have known that God's great skymirrors would not lie. Even the dewdrop mirror reflects the sun, because there is a real sun to reflect. Light does not reflect nothing - it paints a real picture of a reality. The trees and herds and green grass were otherwhere, or their pictures would not have been reflected there. This one thing is sure-the mirage is not a liar-it tells the truth; but how to understand the truth it tells, and how to understand how it tells its truth, "Ah, there's the rub!"

One of the wonders of the world is that God puts so much beauty in out-of-the-way places. Maybe it is because $\mathrm{He}$ intends to make that place one of the in-the-way places some time. The mirage had hung over the desert ten thousand times, I am sure, before any human eye was there to see it; but it was never other than beautiful. In the long loneliness of the desert-silences these apocalypses of nature were as faithfully flashed from those "Mirrors of the Sky" as if ten thousand spectators were watching the beauteous sight. Great things are doing in a thousand places of earth and sky where no human spectator beholds the sight. The most experienced mariner has seen only small sections of the sea, as compared with its immeasurable and mighty deeps. The astronomer's eye has seen only a little-a very little - of the great goings-on in the stellar skies. And who has found out a tithe of the beautiful things that are going on in the deep forests far back in the mighty mountains. 


\section{Meadow and Mountain}

Edward Rowland Sill, swept to the height of wonder, one day watched a cloud in the making. In his essay entitled, "A Rhapsody of Clouds," he gives his own beautiful hint of how it was done. He says: "It is not often that we can watch, near by, the rapid formation of cloud; but it once happened to me, in climbing among the "American Alps"the Sierra Nevada-to find myself on a crag precisely underneath the line of low-cloud formation. Leaning back to rest against the rock, and looking upward, I saw the mountain drapery weaving itself-out of nothing, as it appeared; blue air on one side of the line; dark, slaty films (nearest it), then shreds, then masses of flying cloud, on the other. Clear across the sky extended the distinct edge of this swift and incessant weaving. It was like nothing but a great, shadowy banner streaming out in the gale from an invisible cord strained tight across the sky." To see with Sill's eyes was to see what was doing up there among the clouds and the sky. But long before Sill's eyes saw the light, that weaving of beauty had been repeated more times than man's mind could count. From the spot where I write this essay I can see the huge clouds literally rolling from the brow of "Old Baldy," as if some giants of the heights were tossing tons of irregular-formed snowballs. The play of the clouds across those splendid summits and down their granite slopes is bewilderingly beautiful.

Well, I was saying a while ago that the mirages were in the making before any man arrived on the plains to see them. The Maker of the mirage saw them, and must have been well pleased. How good it is that all the good things and the beautiful are not in one place. The thing that is needed most is put in the place where it is most needed. 


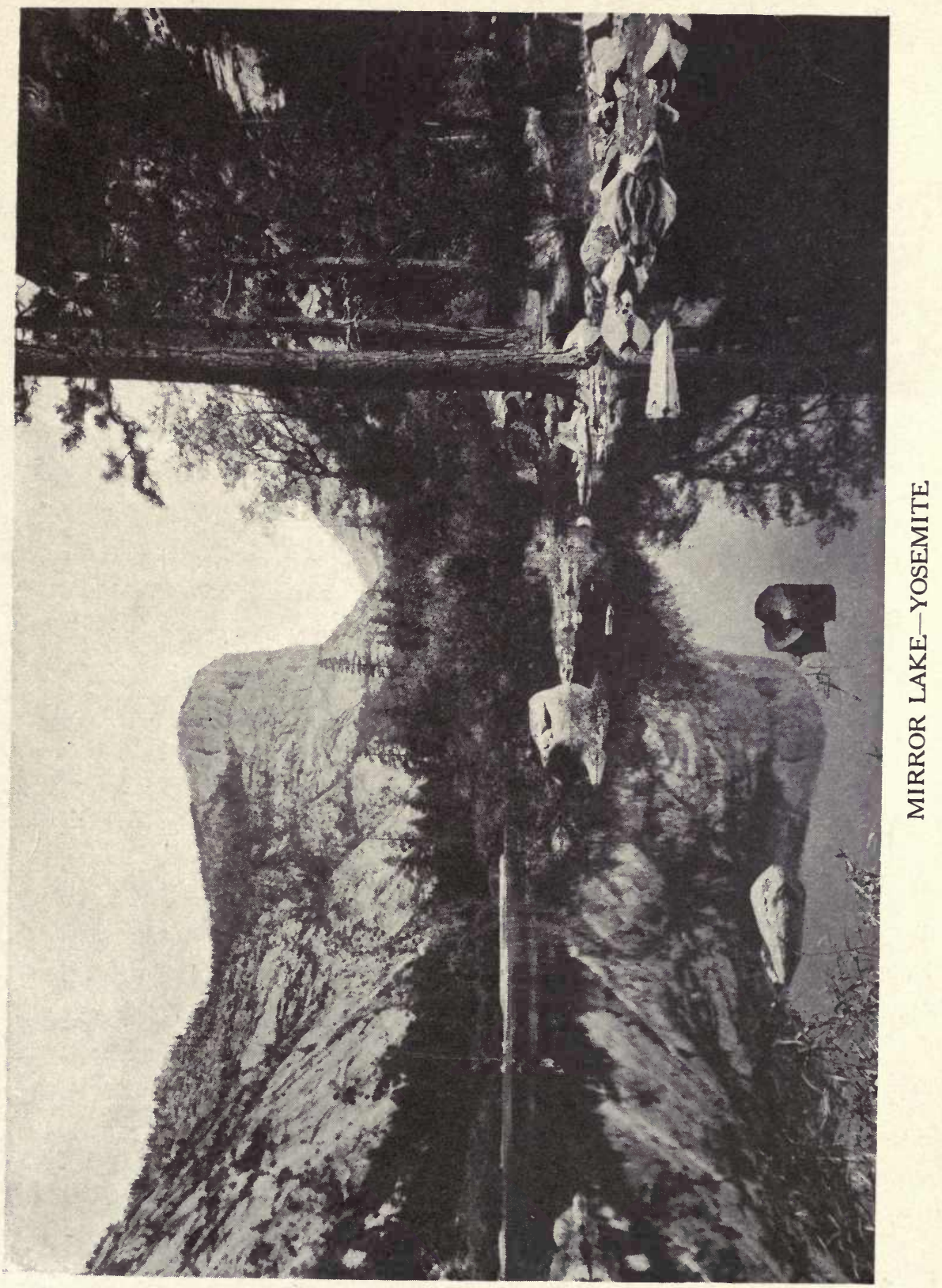


andmons 


\section{The Mirage}

The mirage is needed, with its refreshing beauty, out among the weary wastes of sage and sand. And the mirage is there, and the traveler is there, and the loneliness is there; but the lure that lifts away from loneliness is also there. There is always a lifting influence to help lift our loads, if only we do not miss the way. But this is not a homily-it is only a meditation on the mirage. I want you to catch its unwordable wonder, and to come under the spell of its lure, and to feel the fineness of its wondrous beauty. I will leave off speaking now, and you shall hear another's song of-

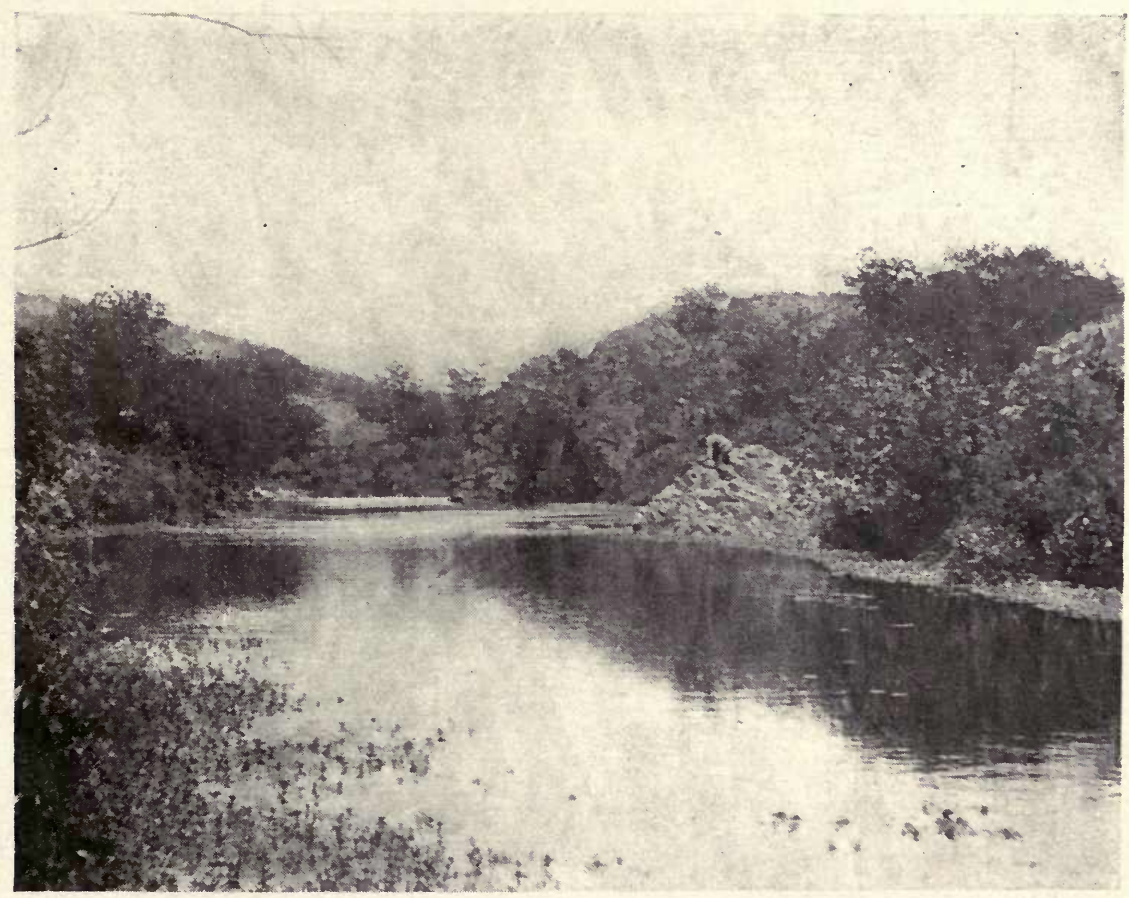

MIST ON THE HILLS 


\section{THE MIRAGE}

Over the sun-scorched, glaring sand,

Under a pitiless, molten sky,

Luring on with a mocking hand,

Over the stretches, white-hot and dry;

Painting a picture of rippling streams,

Grassy valleys and cooling shade-

There in the desert it glows and gleams, In magic beauty of light arrayed.

Out in a withering, vast expanse,

Parched and shriveled and dead and bare;

Out where the shimmering heat-waves dance,

The wraith of the desert gleams on the air.

It lures and calls in enticing strains,

As its waters lave on a shining shore,

And whispers of billowy, fertile plains,

And bloom-decked hills I would fain explore.

Over the stunted sagebrush sea,

Under a glimmering, sweltering sun,

It beckons, beckons and smiles at me,

As its wimpling waves of waters run.

Only a ghost of a green-clad vale-

A desert specter that lures and snares-

It calls me over a death-marked trail,

Into a furnace that seethes and glares.

It fades and dies as I reel ahead

Over the arid and burning waste-

A picture of beauty an instant spread,

And then forever from sight effaced.

But over its bosom flame-hot and white,

The bones of many are bleaching bare,

Who turned aside at the luring sight

In the painted depths of the desert's glare. 


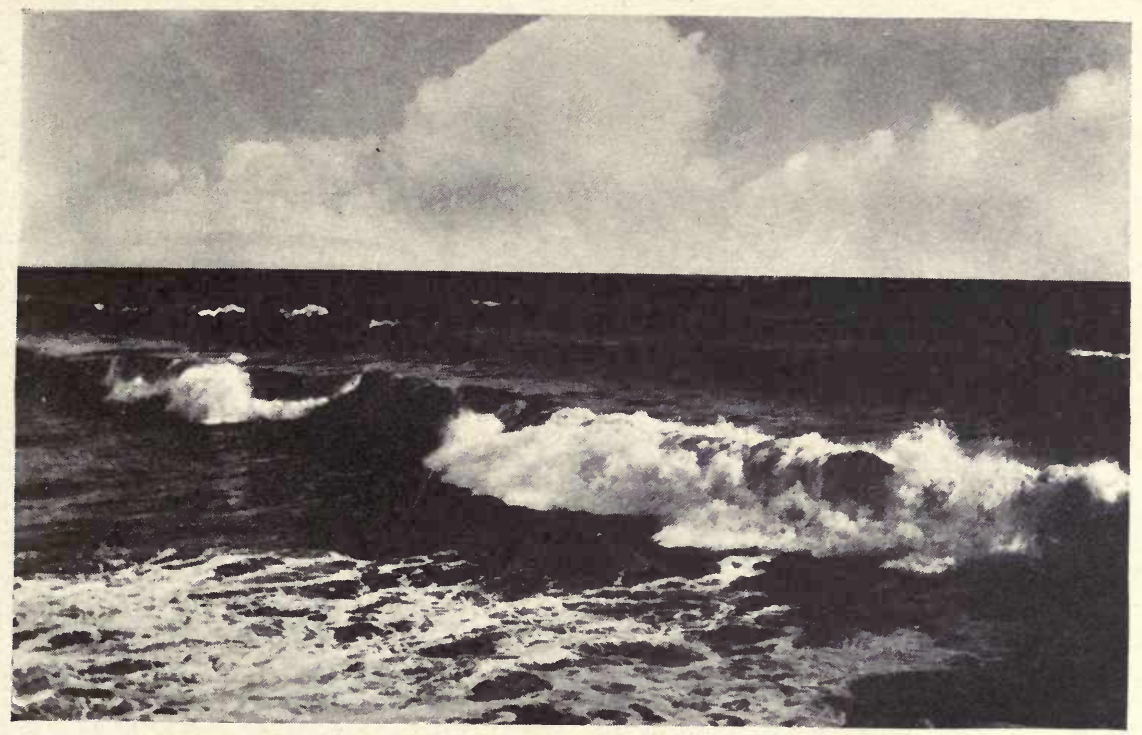

"AS ITS WATERS LAVE ON A SHINING SHORE"

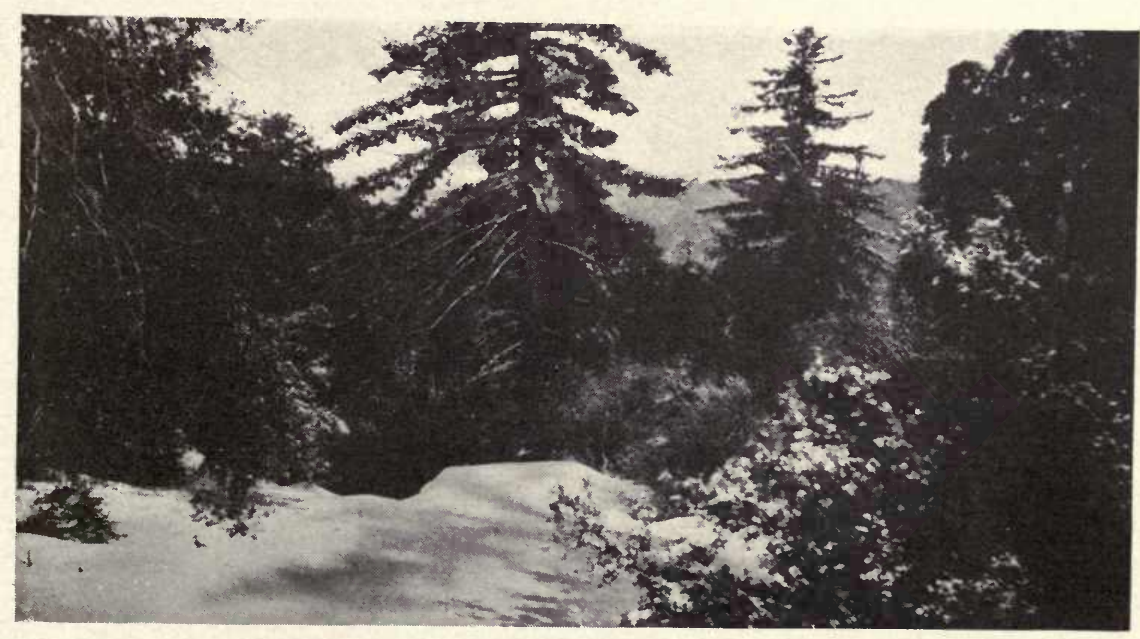

"ONLY A GHOST OF A GREEN-CLAD VALE" 


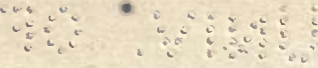

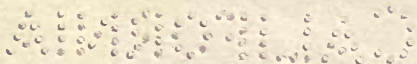




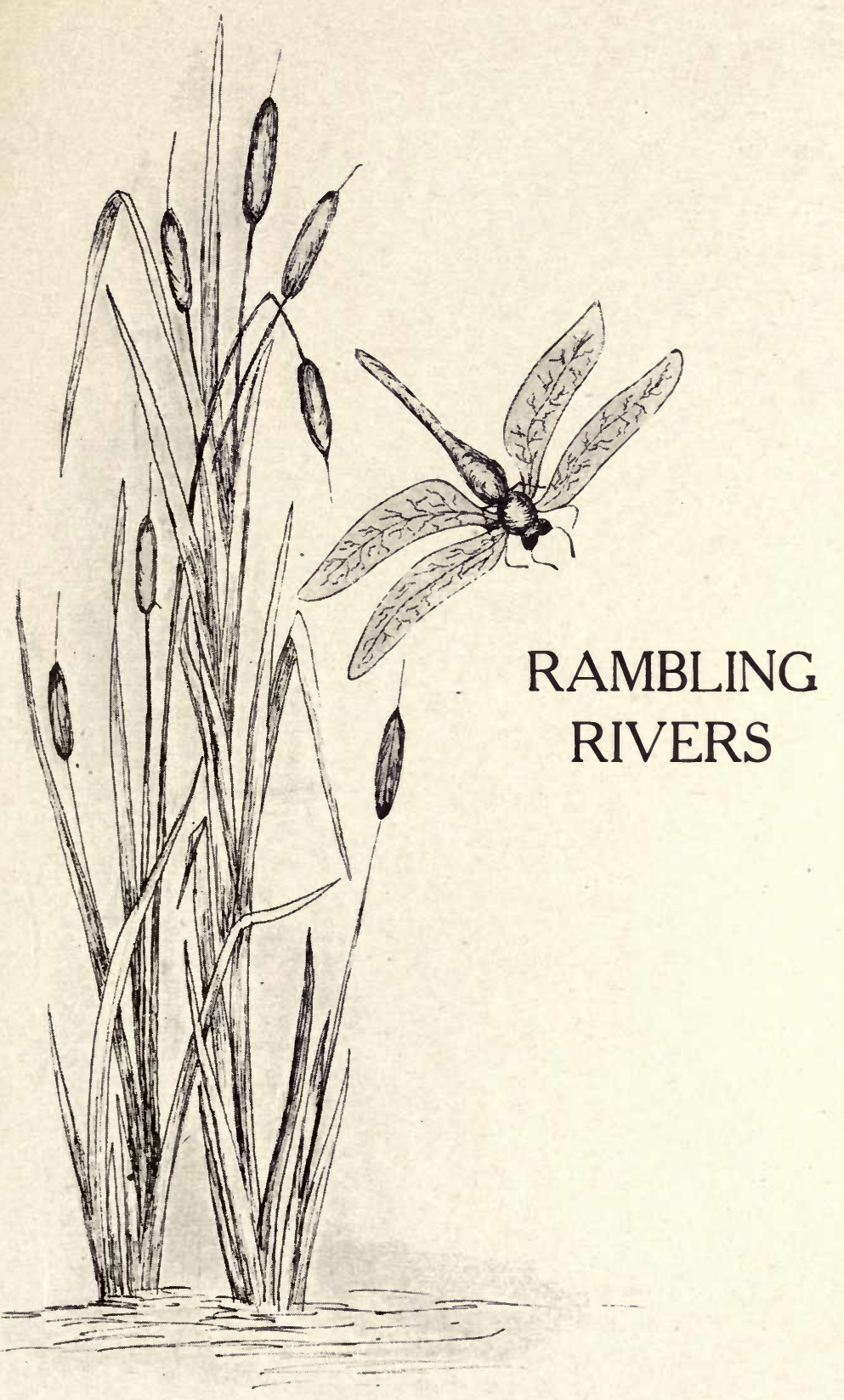

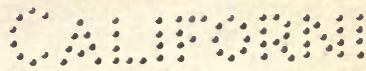




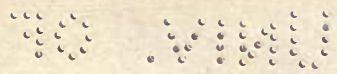

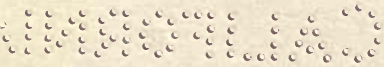




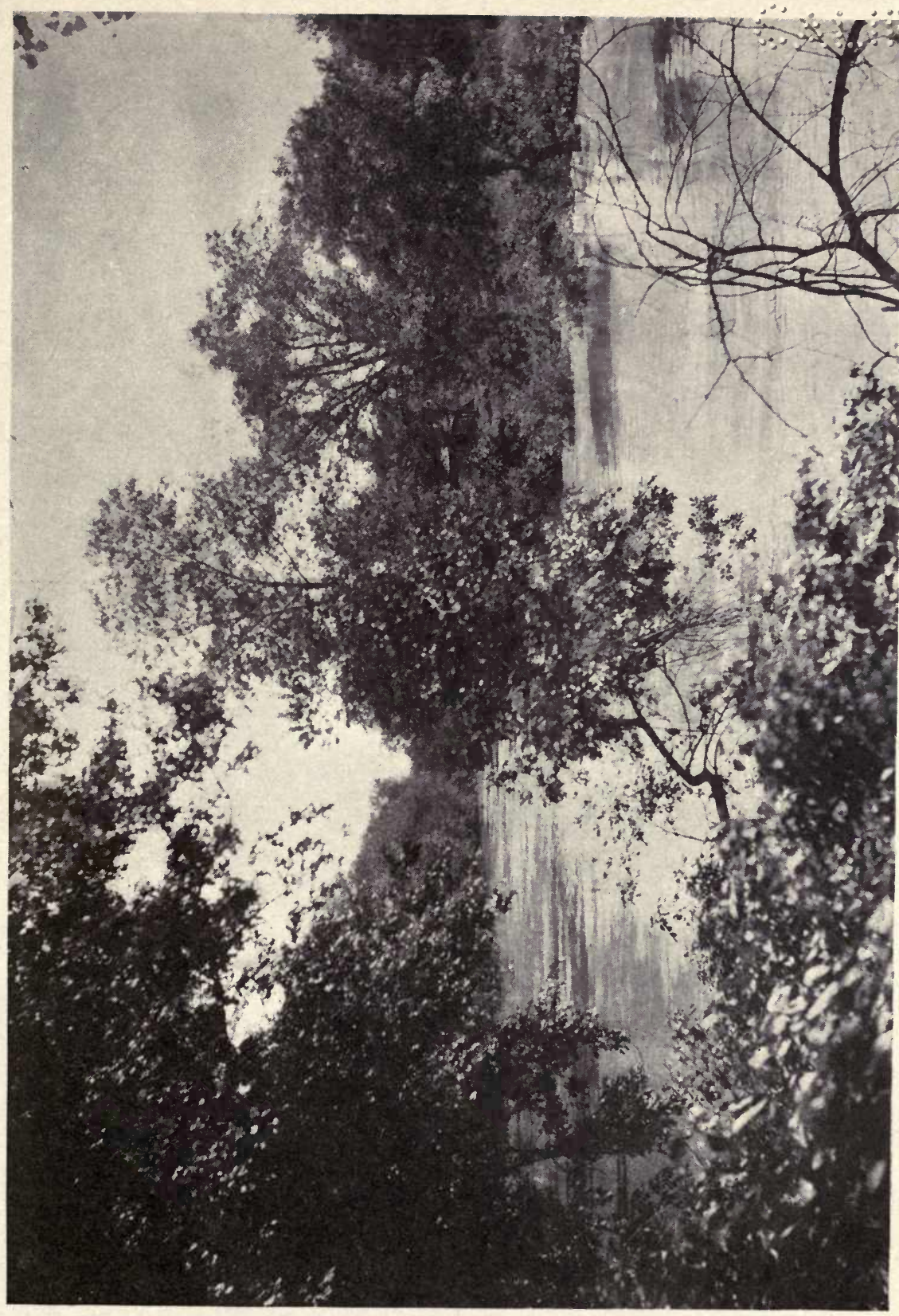

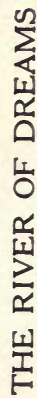





\section{RAMBLING RIVERS}

THE river of the highland is the river of the lowland. The plunging cataract of the mountains becomes the slow-moving and pacific river of the prairies. As if tired of tumultuous tossings on its way down from the dizzy mountain steeps, it glides leisurely and lazily across the level stretches of the prairie. The river is a pilgrim. It is on a long journey from the mountains to the sea. I do not wonder that it grows weary on its winding way. I do not wonder now that the river loiters across the level land, having sped so swiftly from its high sources in the mountain snow.

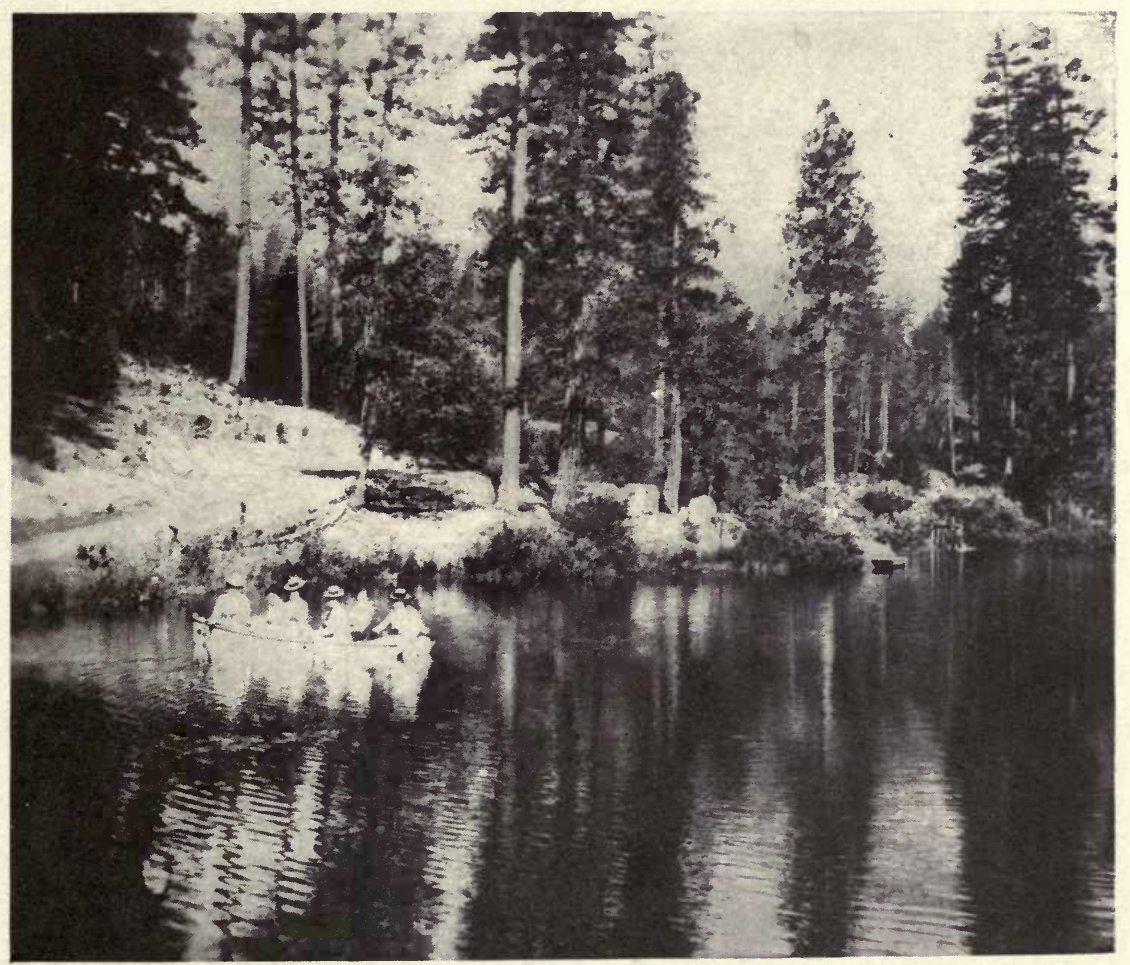

GLEAM AND SHADOW 


\section{Meadow and Mountain}

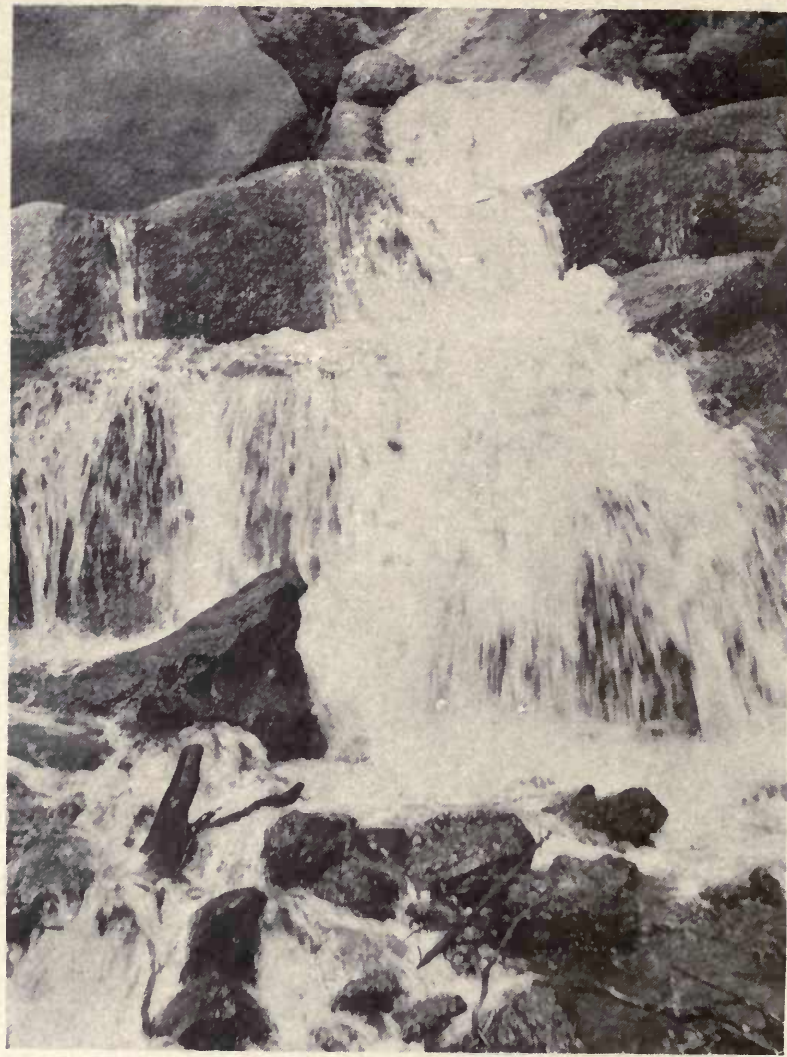

"TIRED OF THE DIN OF ITS OWN DASHINGS"

These waters are weary, and must drift and dream a little on this pilgrimage to the sea. Tired of the din of its own dashings, it would hush its murmurings and slip away to silence and to sleep. Underneath its flecks of foam it would fold its tired arms to rest while the red-wing blackbird trills his music through the marsh. The meadow-lark, blithe bird of the prairie, will pour his flute-notes on the wind as he swings in joy amid the bluestem on the river's bank. The pussy willow will sift its fragrant bloom at the river's edge in summer time. 


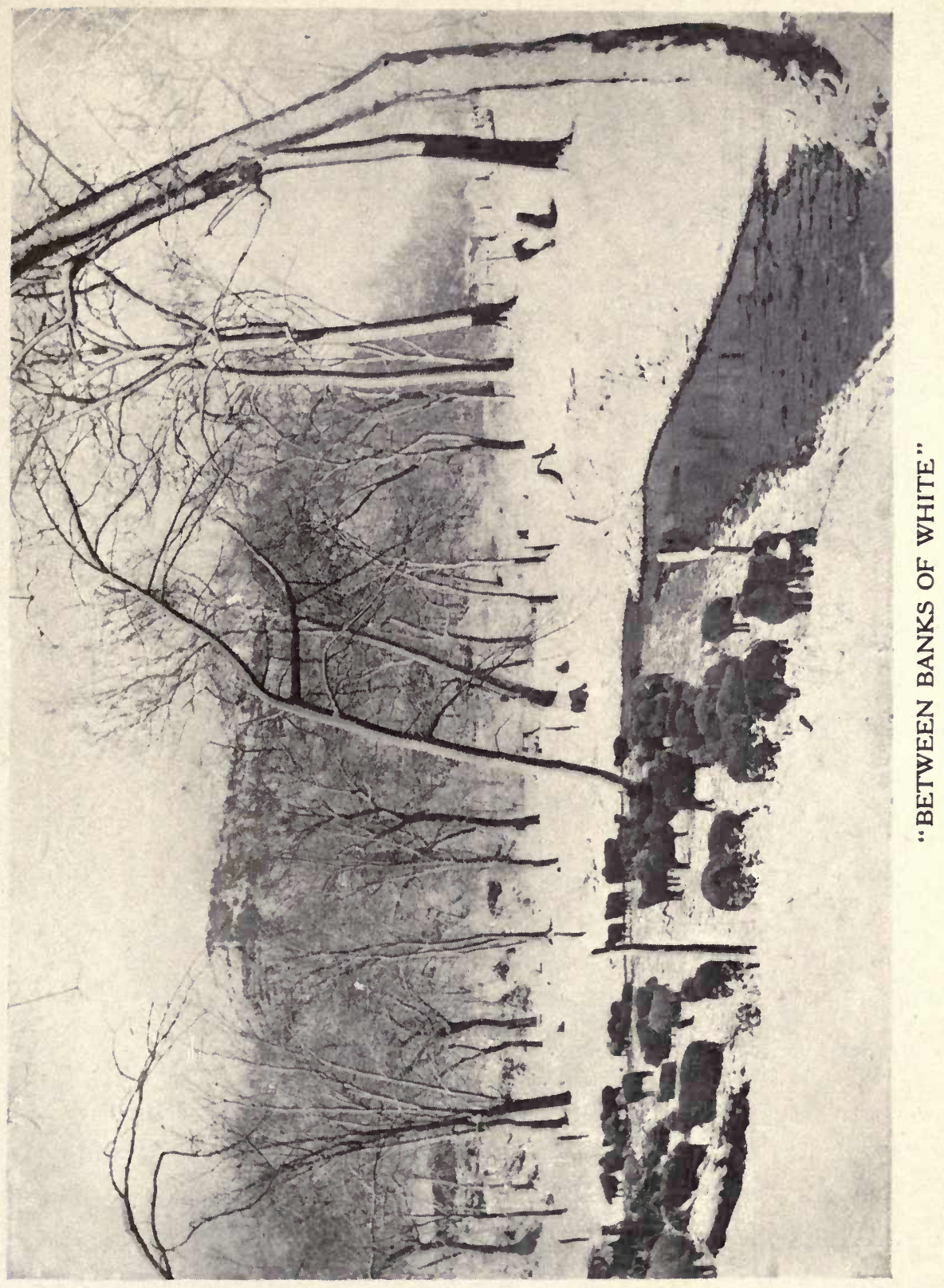


$\therefore \quad \therefore 0 a \therefore a$ 


\section{Rambling Rivers}

For beauty of curves and overhanging tree-boughs, the Walnut and Smoky Rivers of Kansas are good enough to be far-famed. Here alone is poesy aplenty for the singers of a century. There is the leaf-drift on the slow-moving surface in autumn. There is the tinsel and glitter of the frost when winter's breath blows across the drooping shrubbery on the banks. And when the big-flaked snow falls, moist enough to cling to every bush and tree, the river runs like some dark ribbon between the banks of white. The tangled vines that fall in lovely loops to the water's edge make a covert for the redbird and the chickadee. Completely covered with the close-laid snowflake shingles, these tangled vines are places of shelter and of beauty. Every snag and stump looks sightly in its unstained dress of snow.

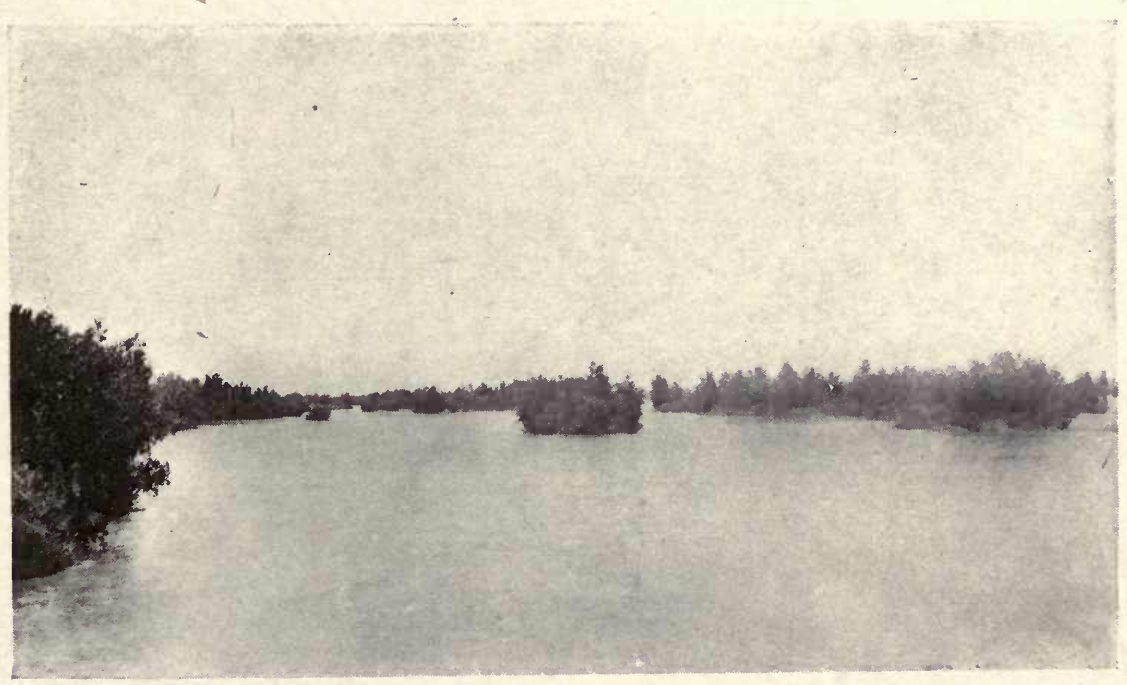

"IT WOULD HUSH ITS MURMURINGS" 


\section{Meadow and Mountain}

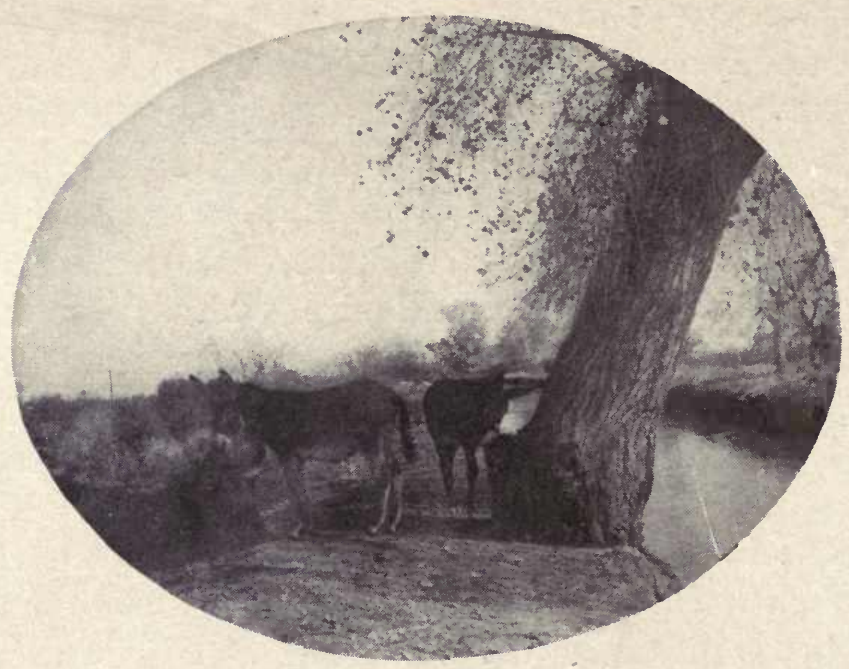

"When spring comes home," the snow is gone and the blossoms come along the river. The horse-chestnut, the redbud, the wild-plum, and the blackhaw mingle their crimson and white with the green of the new-leaved trees. You would scarcely know the river now, or the cottonwood tree that stands on the brink with its feet in the tide.

The variety of trees that grow along these prairie rivers is phenomenal. Ash, hackberry, walnut, pecan, box-elder, blackjack, elm, willow, plum, blackhaw, the Judas tree, several kinds of oak, and other trees are scattered along these river valleys of the prairies. In and out the rivers wind among these trees, caressing them to beauty and to bloom. When nesting time is come, and the humming of bees, music steals across these woodland shades. On these serenely-glid- 


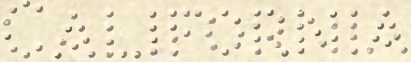

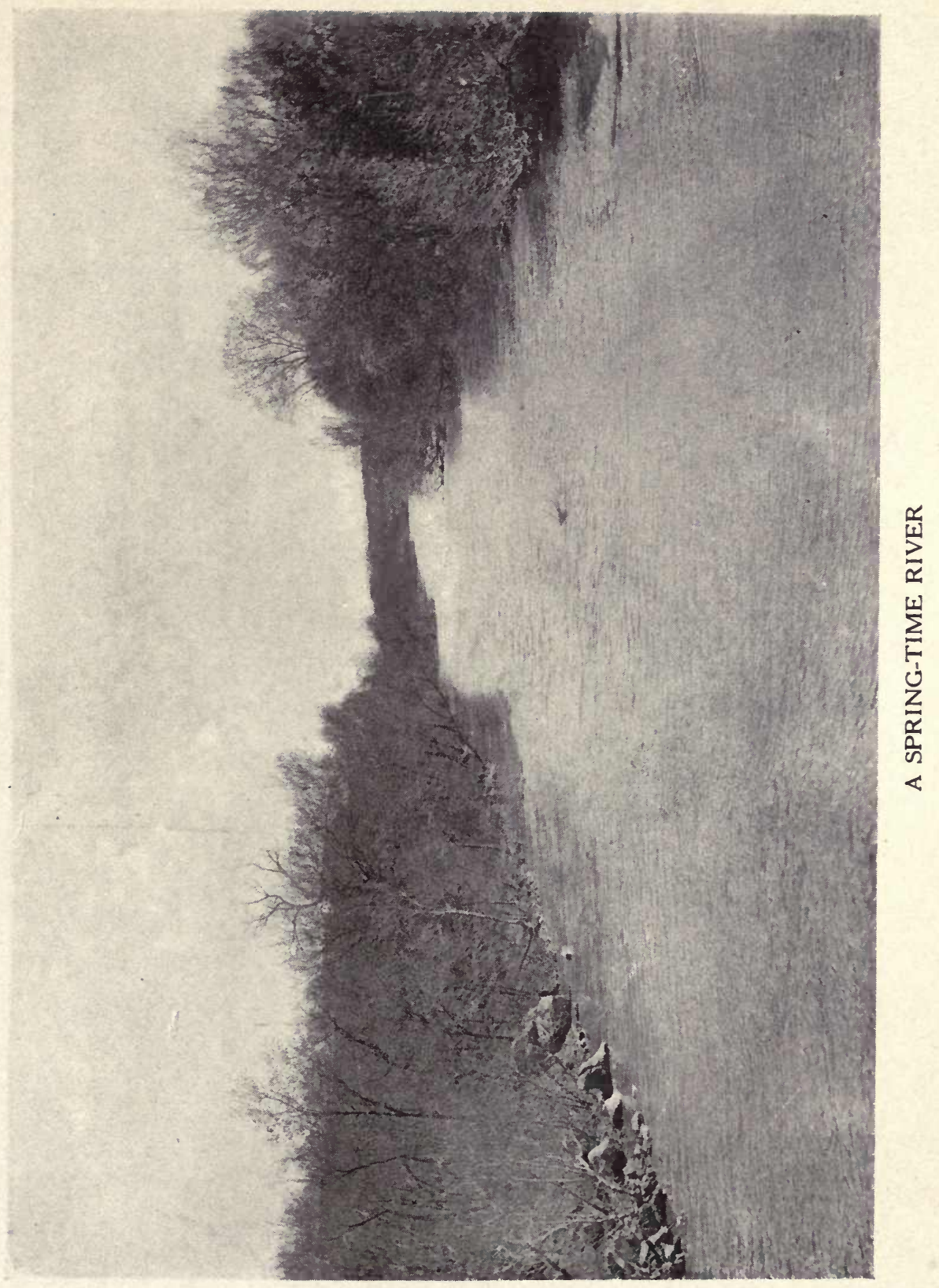




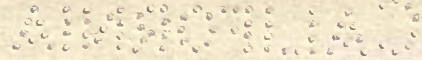




\section{Rambling Rivers}

ing waters the willows drop their autumn leaves like yellow flakes of gold.

Often in the spring time vagrant winds sift the bloomy snow from hawthorn and wild-plum down upon the wimpling waves.

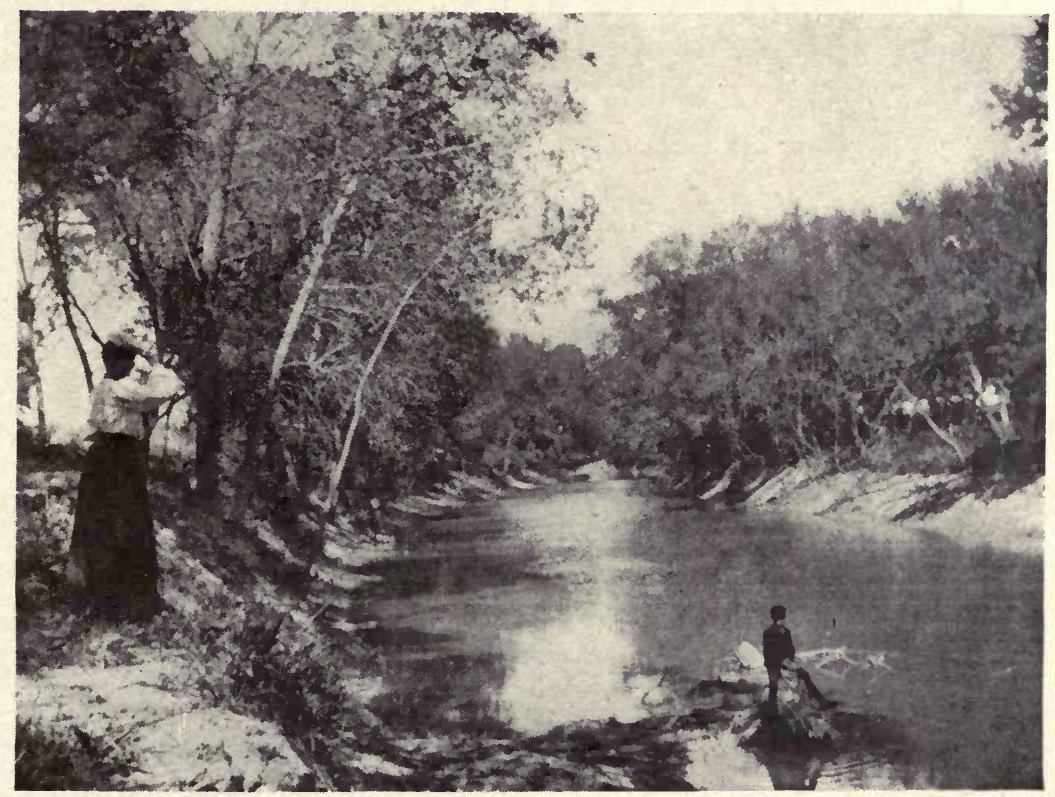

"THE SMOKY" 


\section{A SONG OF THE RIVER}

I sing of a river, the sinuous stream

Whose music and beauty drift into my dream,

Whose slow-moving current at low-water tide

Slips soft through the shadows where cool fishes glide.

Glad river, I sing of thy wimpling waves,

Of the trees whose feet thy slow water laves,

Of twittering birds in the boughs overhead

That sing till the leaves of the summer are fled.

From the season of bloom till the falling of snow

We mingle our mirth with thy laughterous flow;

Like leaves on thy bosom the lover-boats lie

When "The man in the moon" looks down from the sky.

$\mathrm{O}$ river of light, of darkness and dream,

A symbol of life to my vision you seem;

With your dimples and wimples, your passion and peace-

And you will sing on when my music shall cease. 


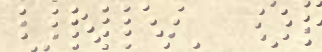

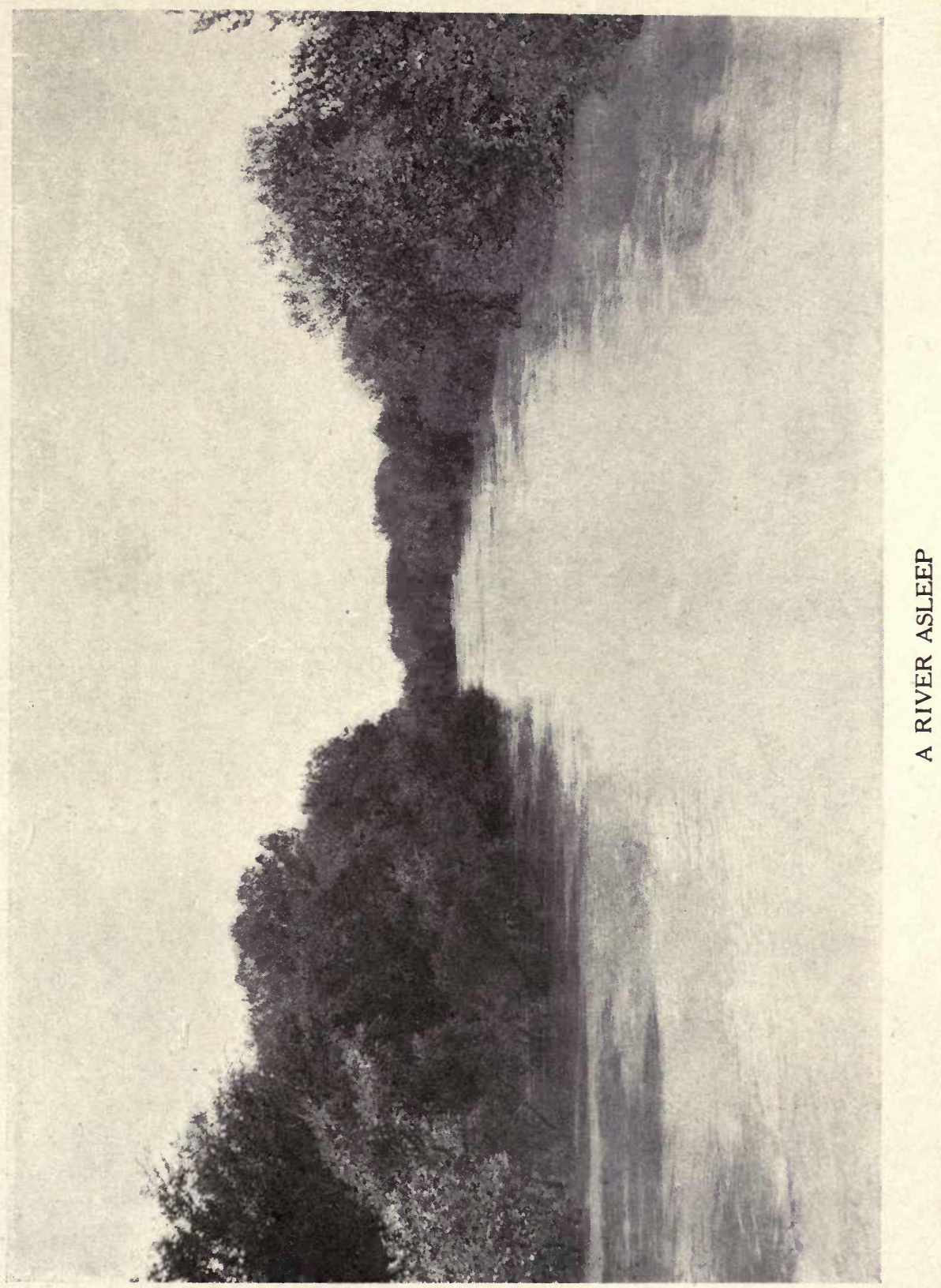





\section{Rambling Rivers}

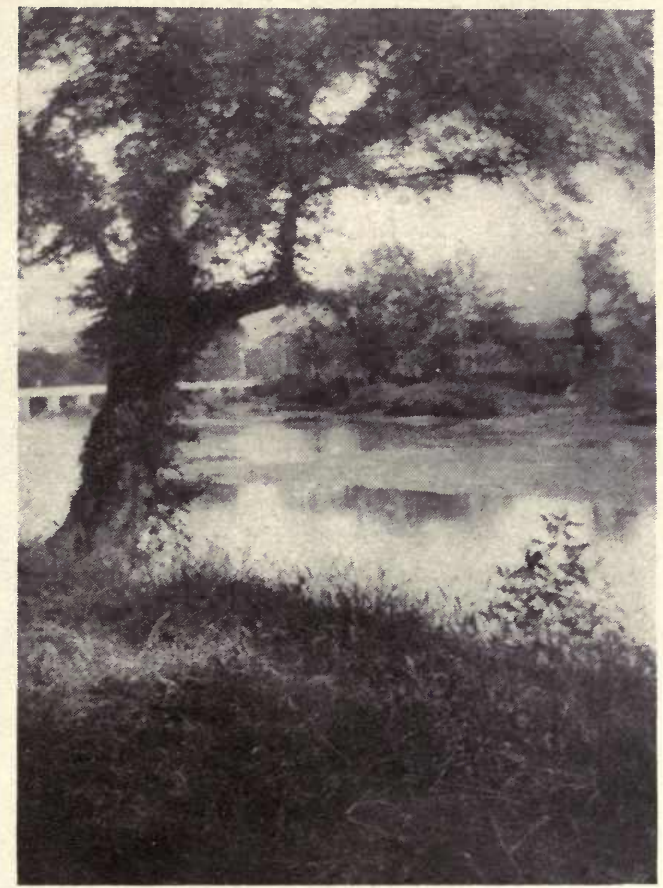

SALT FORK

In some of the river valleys of Oklahoma, and in Paul's Valley of that country, the green leaves and snow-white waxen beads of the mistletoe show their beauty in midwinter. In that country the cottonwood seems to be a favorite tree for this lovely parasite. That reminds me that Mr. James Russell Lowell, in writing about the hymn, says it is like the mistletoe, which seldom grows on any tree save the oak. In Oklahoma it grows abundantly on the cottonwood. Strolling along the Walnut River in Kansas you will see in the "falling of the year" the beautiful bitter-sweet and the wonderful wahooberry, or burning bush. With the bitter-sweet you are familiar, but the wahooberry is not so 


\section{Meadow and Mountain}

common. It would create a great sensation among our Eastern friends. I think they would mistake its scarlet clusters for wild red grapes.

The "starberry" is a bush of beauty among the defoliated winter trees. It spreads its outer husks like the points of a star.

The oriole swings his nest from the branches of trees that stand like sentinels along the river. You wonder where the birdling babies are this chilly winter day. In spring and summer herons, kingfishers, snipes, bitterns, and a great variety of wild ducks live and laugh along these river ways. The red-wing blackbird builds his nest and sings his song among the river bushes and sedges. And no finer fishes have been found than those which sport and swim in these Western waterways. The mud-cat, the channel-cat, the sunfish, and other varieties abound in these rivers.

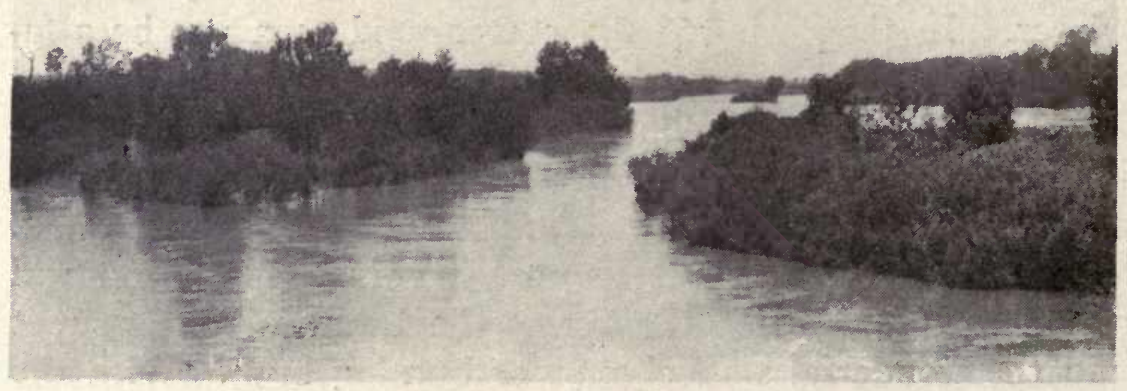




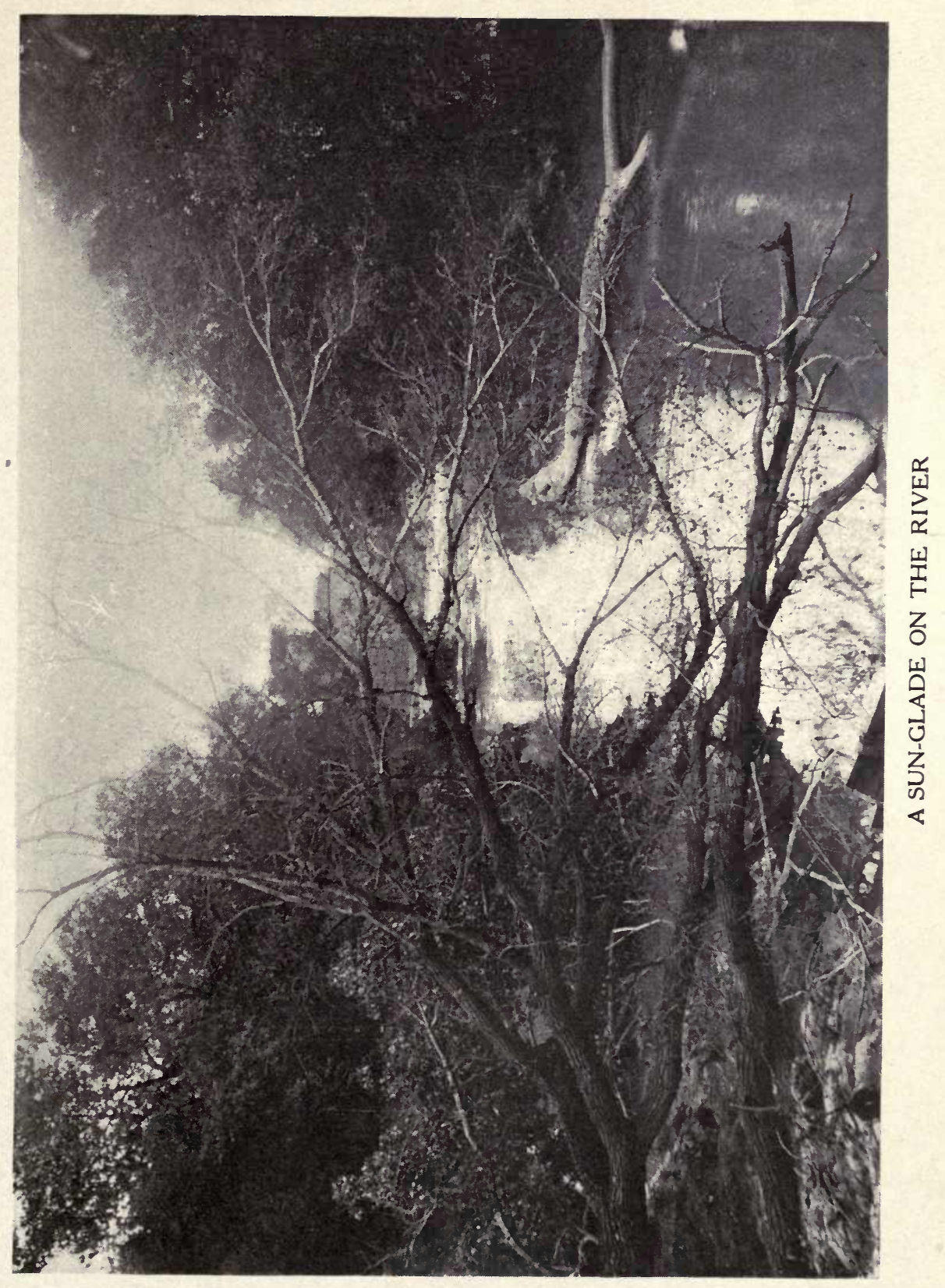


$\because z^{\prime}=-\because \vdots \vdots \vdots \vdots \vdots$

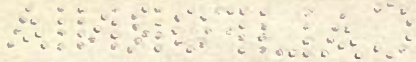




\section{Rambling Rivers}

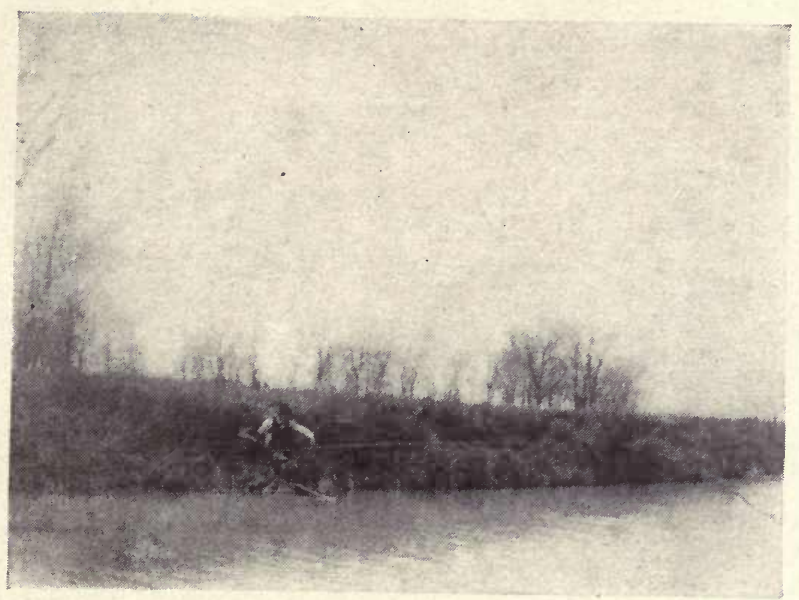

For reasons which he will not disclose, the writer has caught none of the above-named fishes. But there is a beauty about a grass-grown river bank as you watch the play of the westering sun across the waters. You wait and wonder till the chill of the autumn evening mingles with the shadows of the gloaming. The winds of evening twilight whisper through the tops of leafless trees and mind you once again that you are here alone-but where the river is, and the grass, and the wind among the trees, you can never be quite alone. 


\section{Meadow and Mountain}

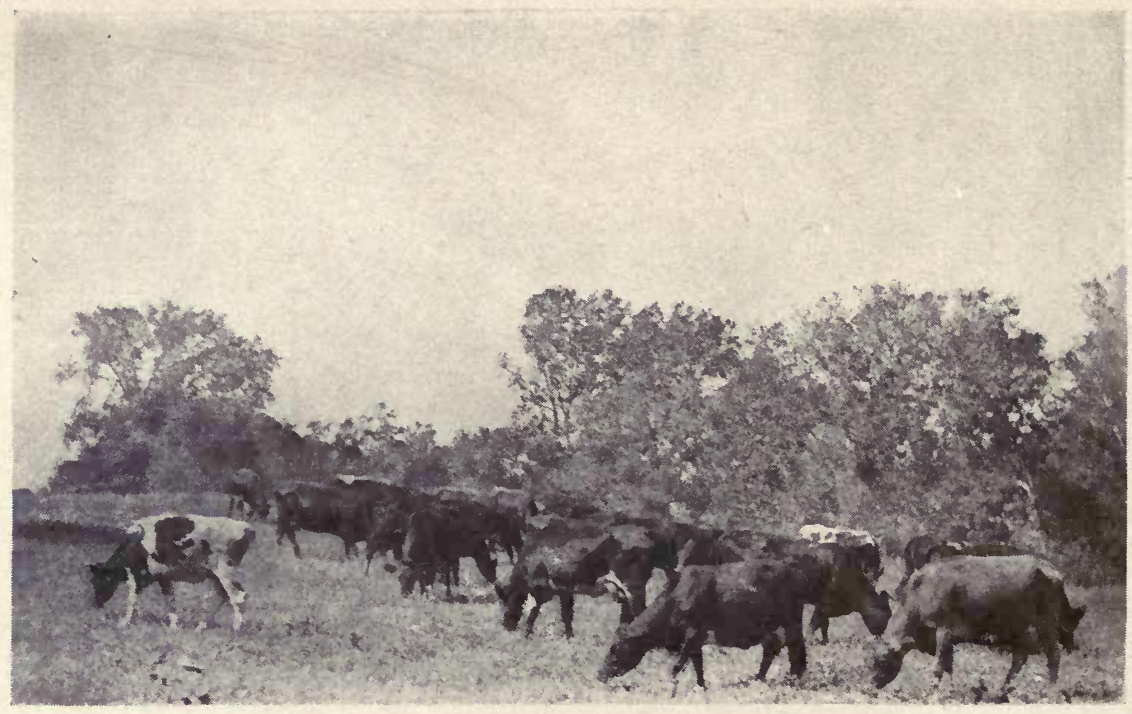

FEASTING

Cattle rest in the cool shade of its tree-lined banks or browse contentedly the lush meadow-grass. In the trees squirrels bark and leap from limb to limb. They build their leafy beds high up in the treetops, and out in the open, as if they loved to have the winter storm swing them fast asleep.

The story of the Western rivers is a story of bewitching beauty. If there is a stretch of country road along the river, and you are taking in the sights, you forget whither you are bound-to the country or the town. You see the wizardry of the light and shade across the water and the trees that hug around the weather-beaten mill upon the bank. 


\section{Rambling Rivers}

Then your eye is caught by the beauty of a tree-covered bluff that overlooks the bend in the river. If you could say or sing what you feel, the speech or the song would be worth the hearing. It is a kind of wordless wonder. It is unvocalized eloquence. It is unsung music. But the birds in the boughs essay to sing it. These bending treetops in full foliage, the slow creep of shadows, the floods of light between the shaded banks, and the color-play across the scene make an apocalypse of beauty at the river-bend.

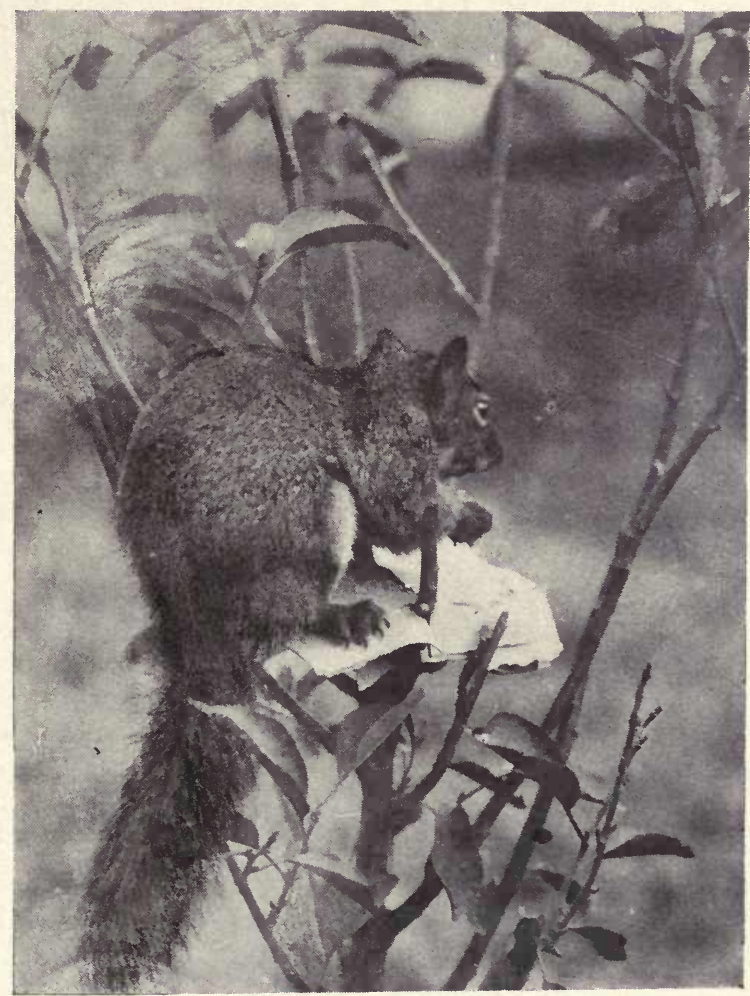

AT HOME 


\section{Meadow and Mountain}

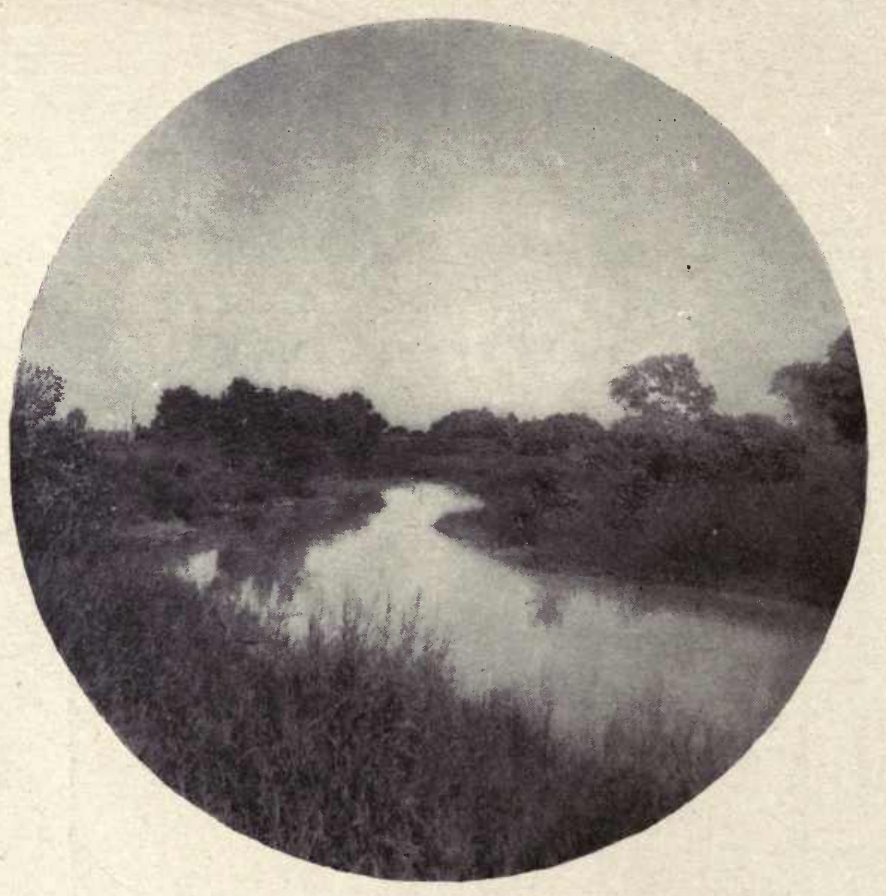

The river in repose mirrors the beauty that bends above its breast. Shadow for shadow and gleam for gleam does the river give to the shades and lights that play above its banks. But these waters linger not. Onward the river glides through rushes and sedges to the murmuring sea. 


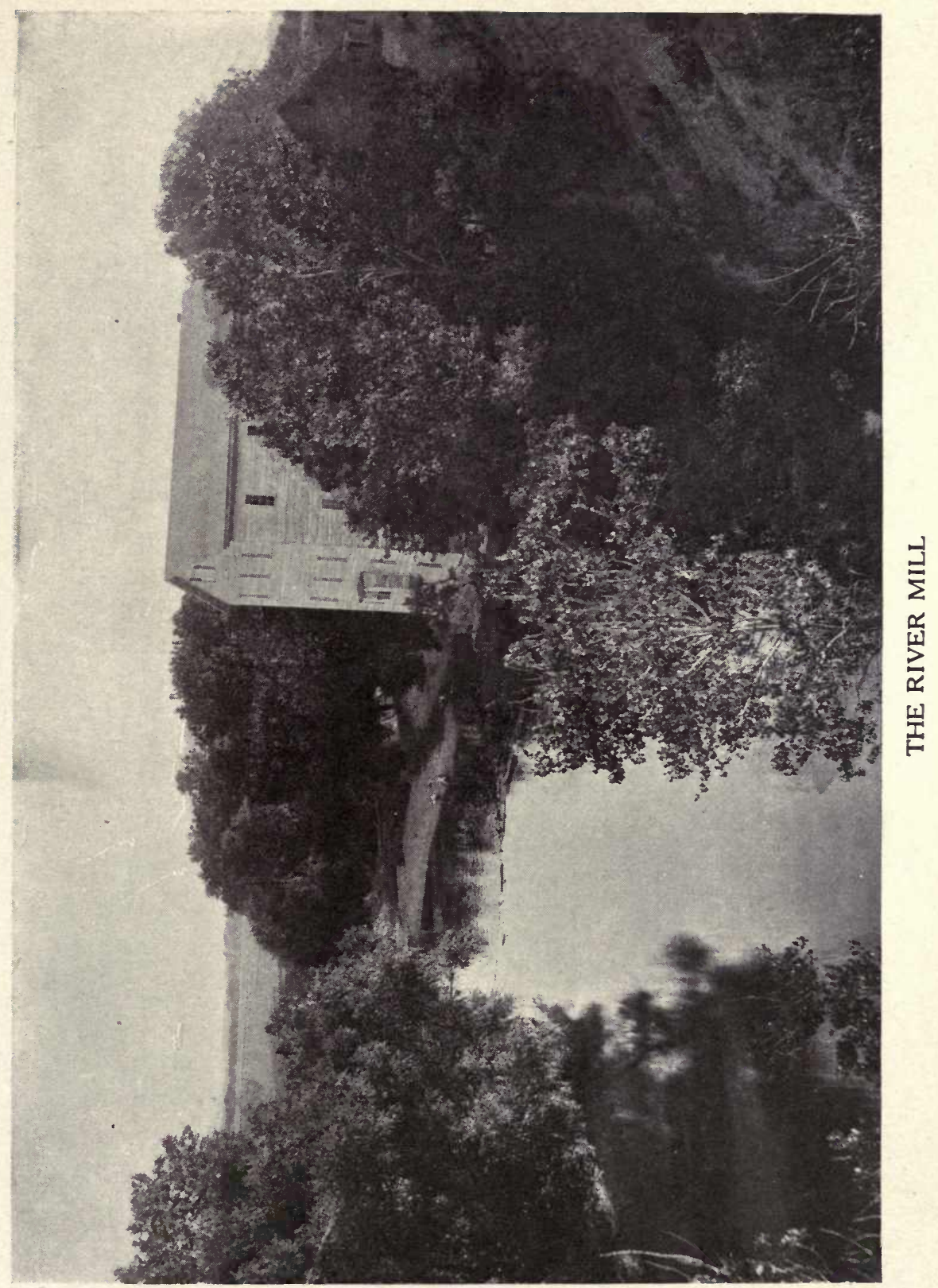


$7 \cdot 4 m$

a 

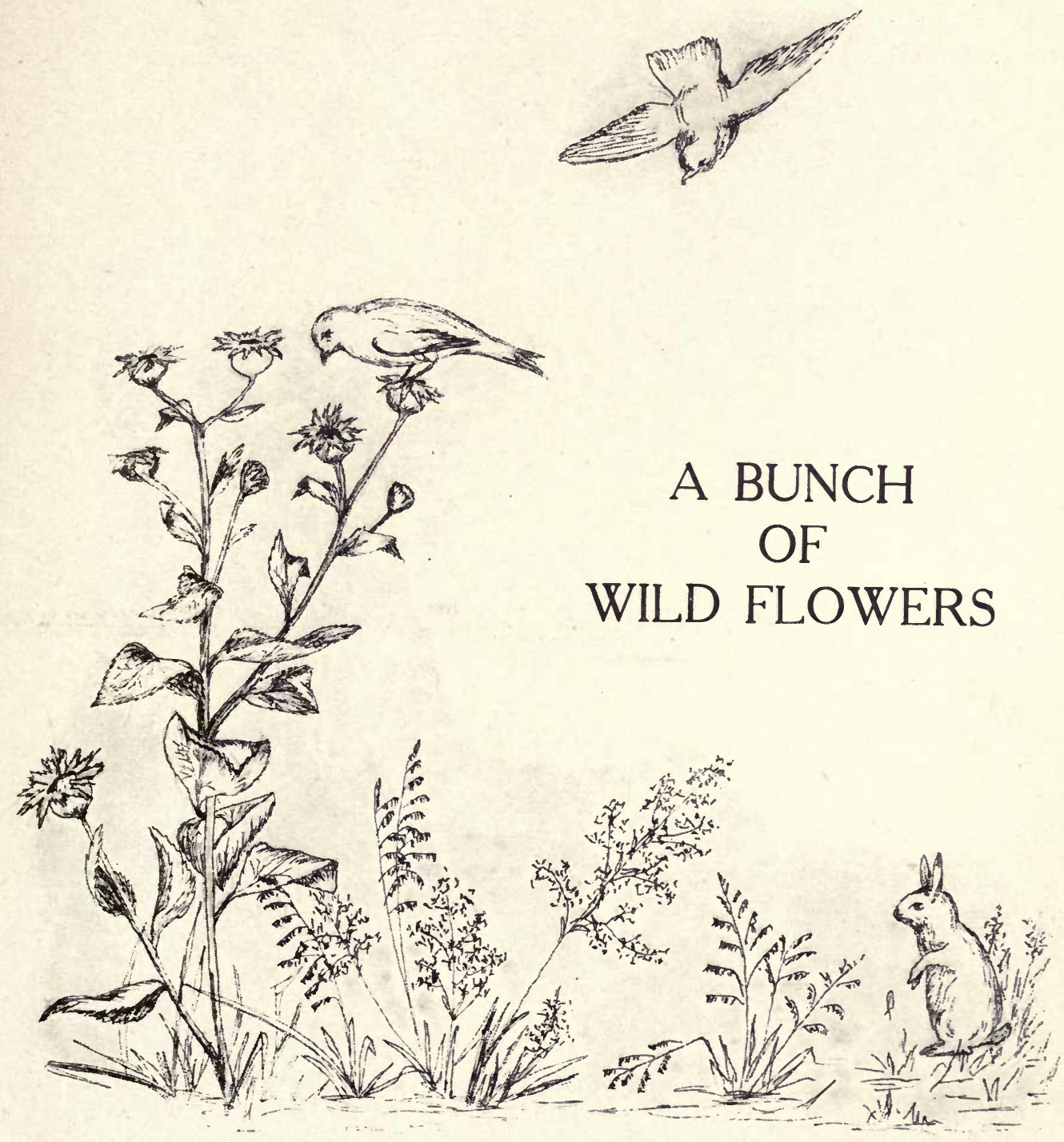



$$
\begin{aligned}
& \text {, }
\end{aligned}
$$

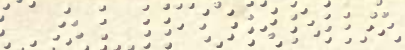

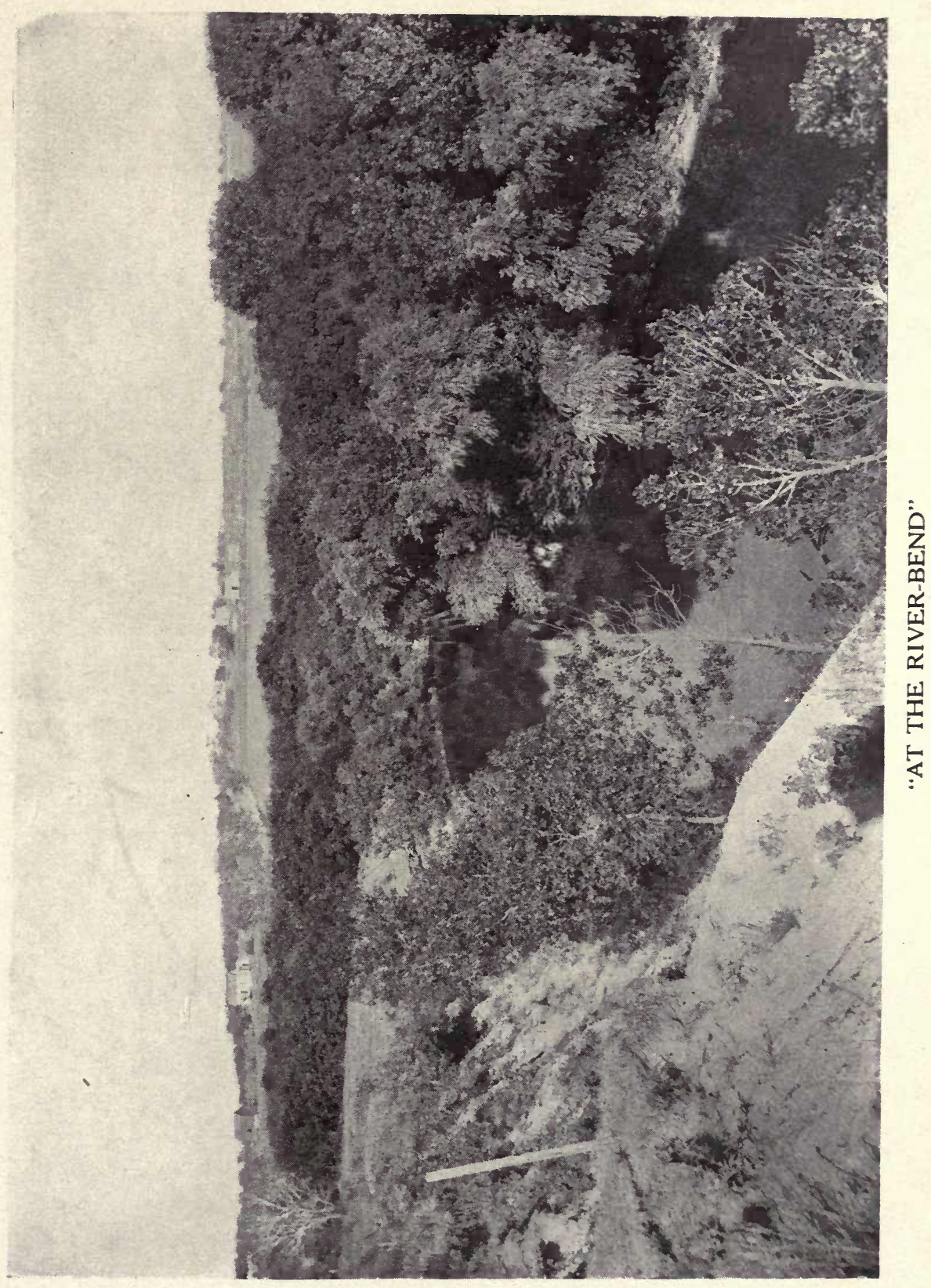




$$
\because \vdots \square
$$

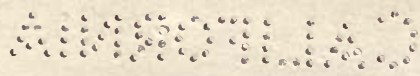




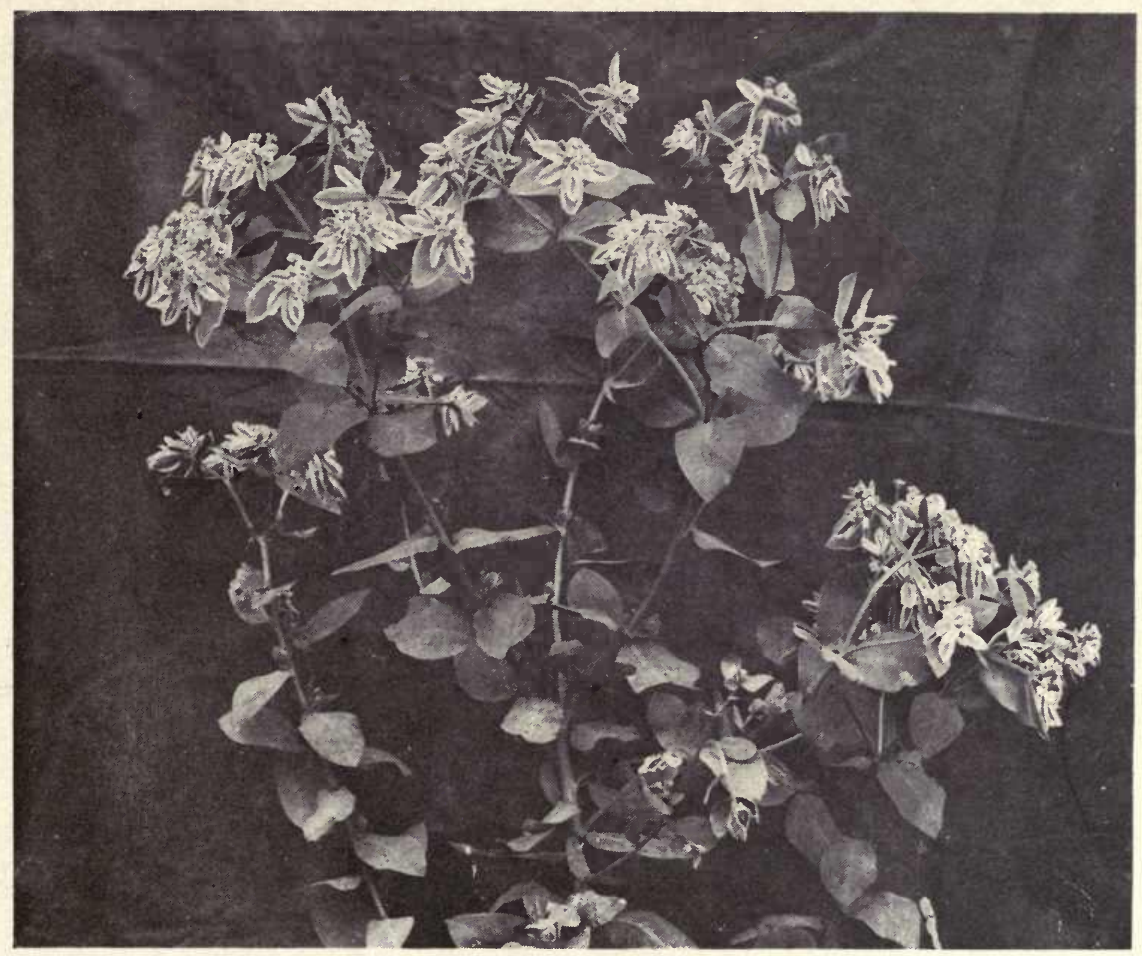

\section{"SNOW ON THE MOUNTAIN"}

Beautiful, beautiful "Snow on the mountain,"

Whence are thy colors so rare?

Thy green and white robes were dipped in a fountain,

A fountain of sun-sweetened air;

Where dwelleth the Artist who mingled thy hues,

His studio where shall I seek;

Does He find His fine oils in the clear morning dews And His tints on the snow-covered peak? 


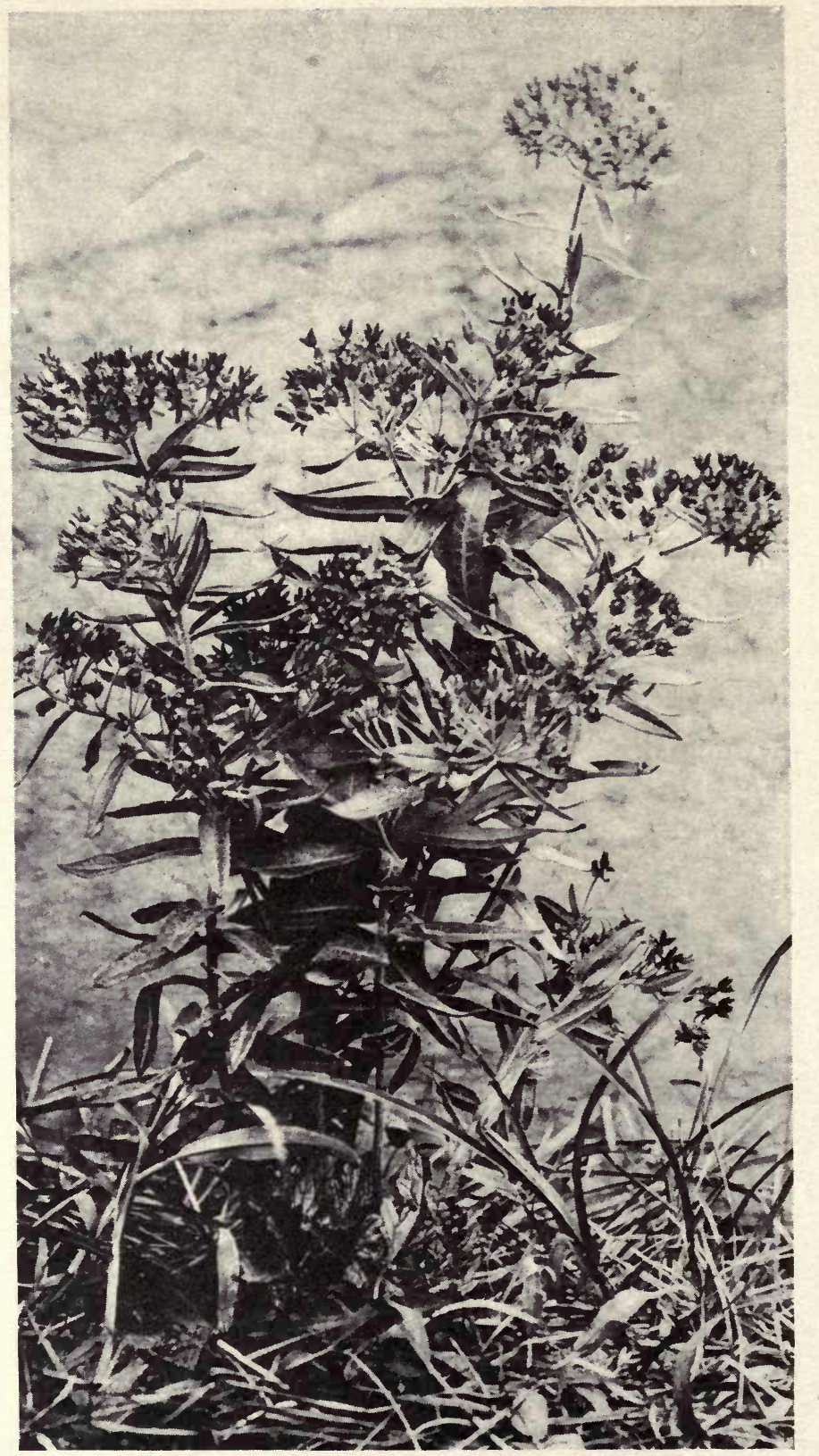

THE BUTTERFLY WEED 

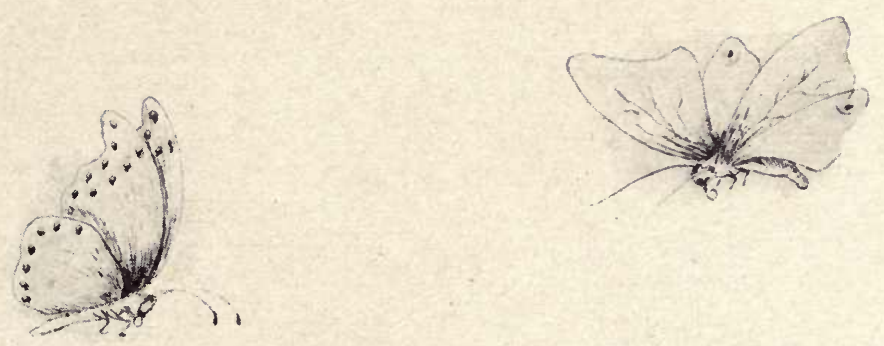

\section{THE BUTTERFLY WEED}

The life that feeds thy tender bloom, I feelThe primal fount whence all thy beauty flowsIs one with that from which my spirit quaffs; Some Workman thy great beauty overbroods, And pedestals some Architect has hung Firm at the base of all thy lovely blooms; Thy flaming orange-tinted colors coax My ardent heart to springtide love of thee; Some holy halo girds thee round, and fills Thy summer atmosphere with wordless joy.

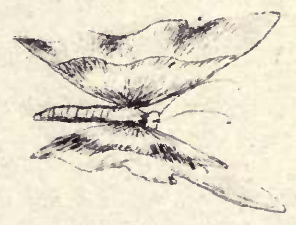




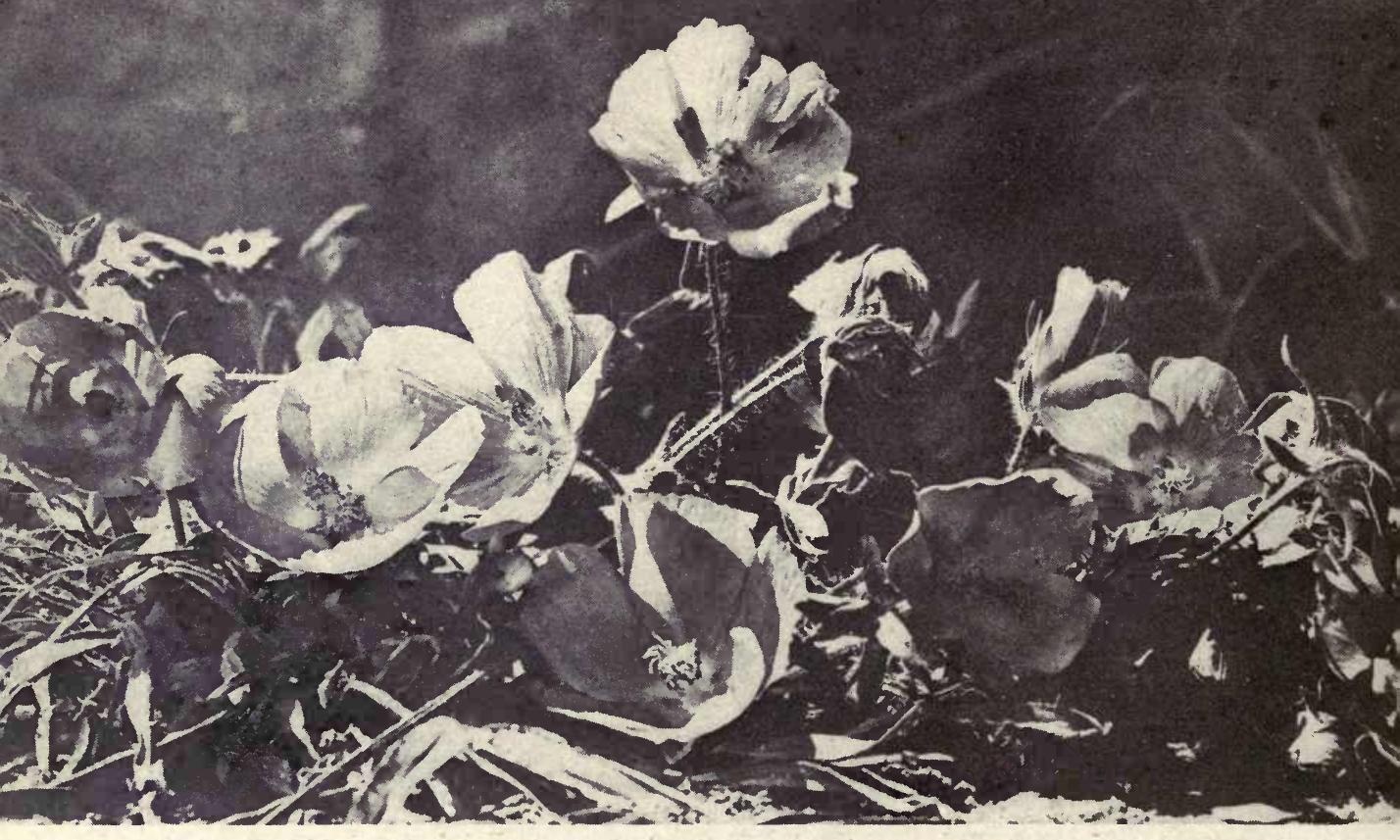

\section{THE MALLOW}

Beautiful magenta mallow,

All the May-time thou dost hallow,

Holding forth thy gaudy cup,

That the clouds may fill it up;

How much rain dost thou consume

With thy fragrant lips of bloom?

How much sunshine dost thou hold

In thy yellow heart of gold? 


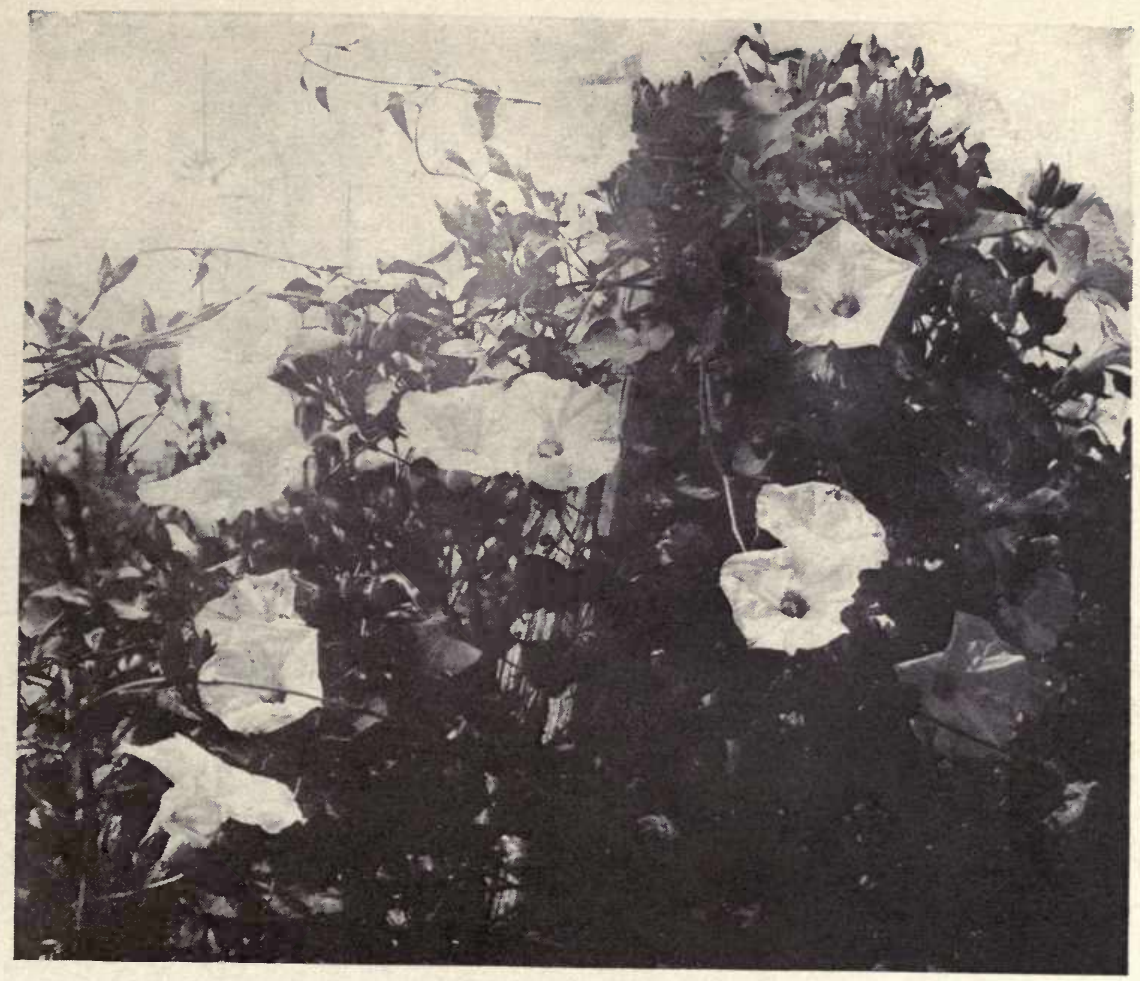

\section{WILD POTATO BLOOM}

Leafless stood the lonely stake,

Dull and dead, a hopeless thing,

Until Beauty, wide-awake,

With her daughters, in the spring, Smiled upon the post and breathed

Breath of passion and perfume,

Round the graceless form they wreathed

Robes of wild potato bloom. 
1. 


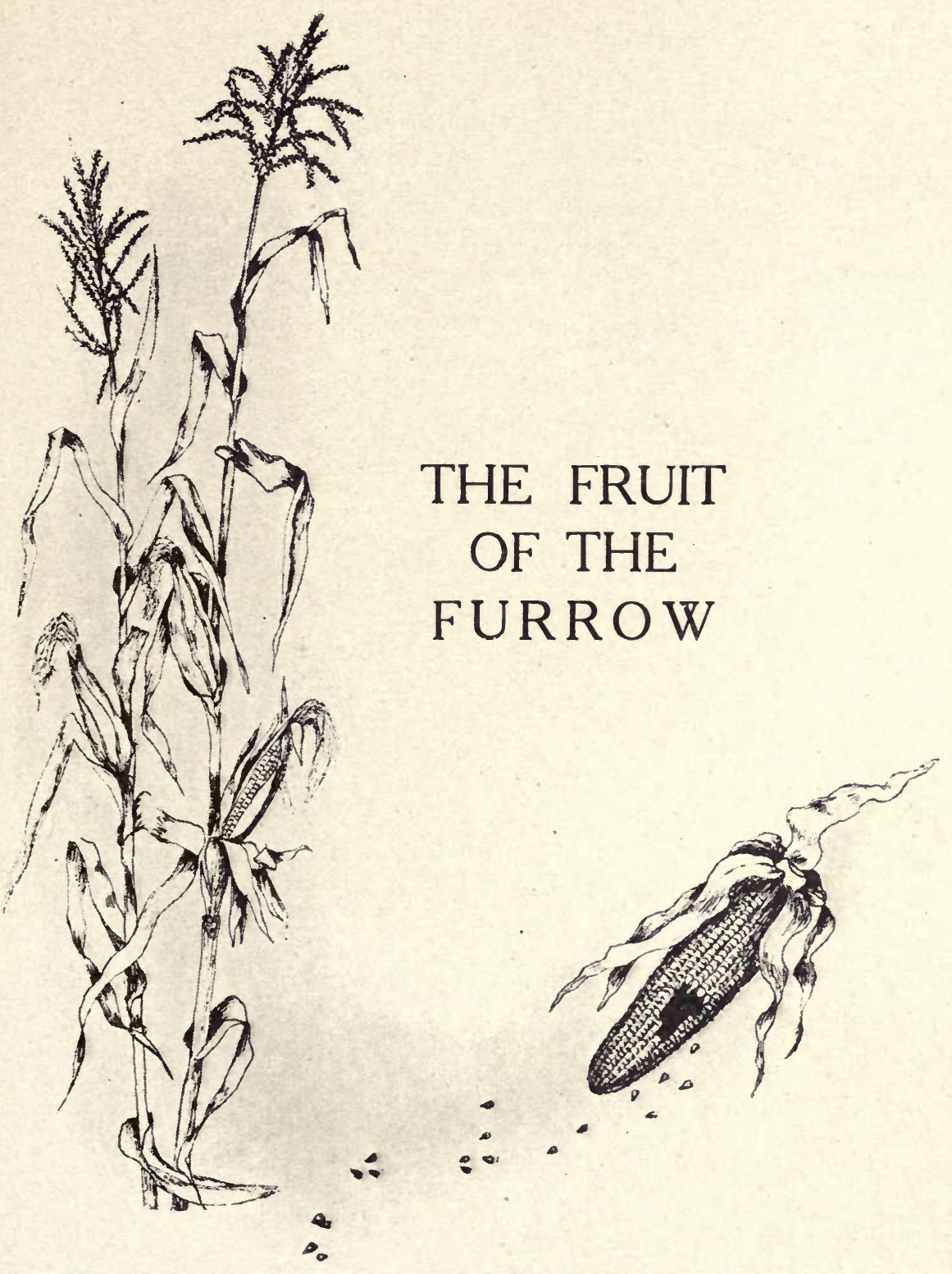


$\because \because \cdot \because \because \vdots \vdots \vdots \vdots$

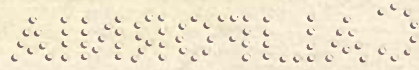




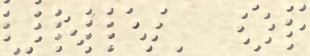

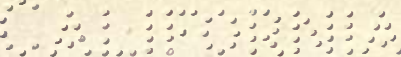

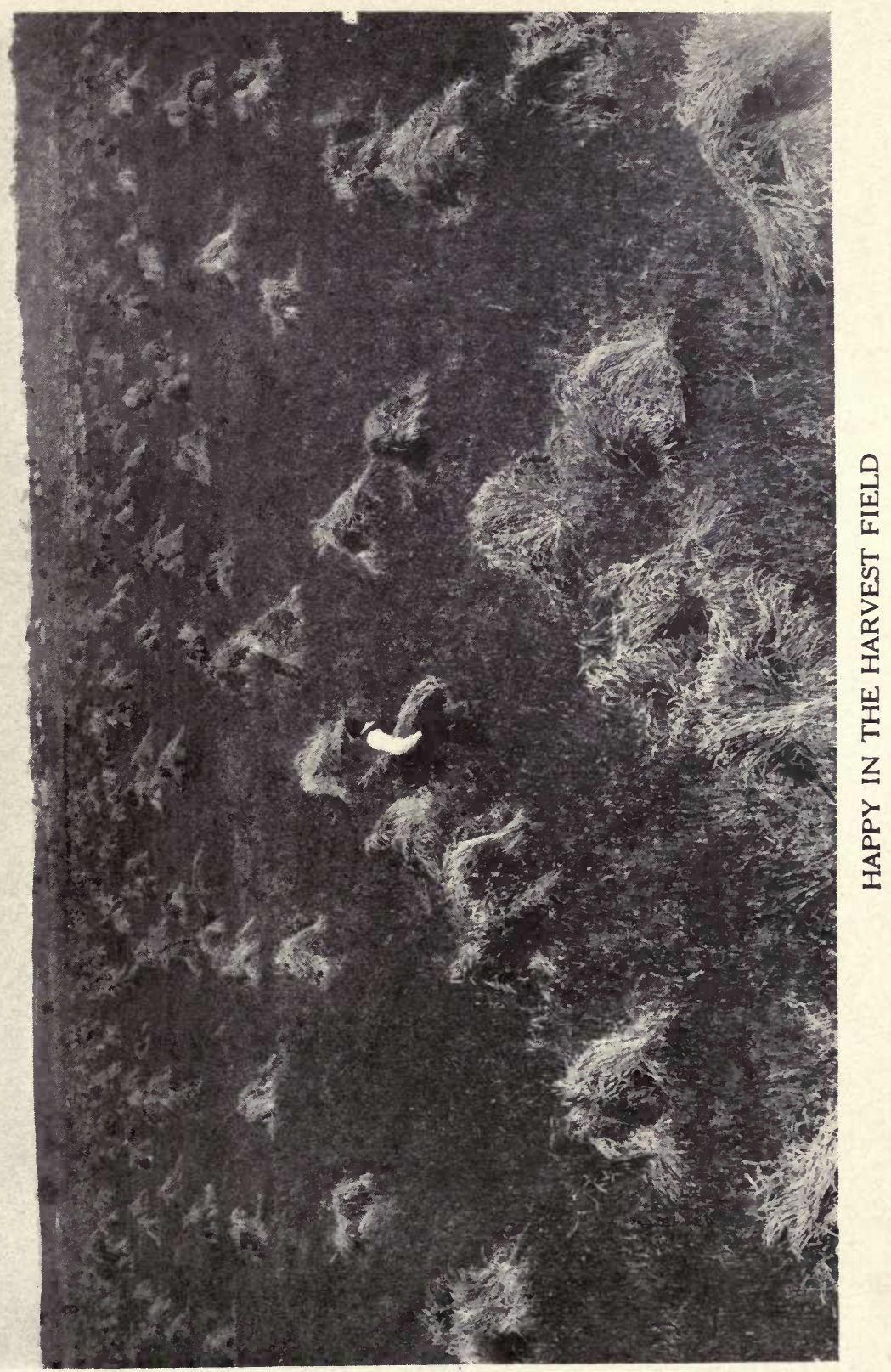


$\because \because \vdots+\vdots \vdots \vdots \vdots \vdots \vdots \vdots$

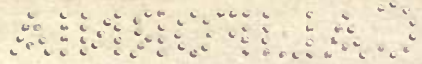




\section{THE FRUIT OF THE FURROW}

THE kiss of the sun had drawn the frost from the soil. Here and there on the prairies bunches of buff baptisia were seen. This is a wild April bloom. The young grass was as fresh as the dawn. Poised on its delicate stem the wind-flower spread its beautiful bloom above the encompassing verdure. The air was vibrant with the musical notes of the meadowlarks. In the early autumn the larks fly about in companies, sometimes as many as fifty, or more, in a flock. They stride through the grass as pompous as knights of the olden time. Now and then a yellow-breast suitor seems to be alone; but it is not good for a lark to be alone, especially in the world's spring time, and near him, on an April day, somewhere in the grass you will find the lady lark. Like her sex of the human species, she is less talkative and more modest than her mate, and like the other lady (or is this like the other lady now-adays?) she waits to be wooed. Some bachelor may raise a question here, but this is no place for idle gossip. Argument would spoil the lark's whistle and deodorize the most fragrant flower. It is better to love and listen, to laugh and sing. The logic of love has led us all farther into the sweet lessons of life than the love of logic. No critic can scold as much into a man in a lifetime as a lark can sing into him in an hour. Let the lark sing. Let the critic listen. The lark's song will teach him sweetness. 'The lark's step will give him the secret of success. If the lark can not get to where he wants to go with his feet, he takes to wing. That is his 201 


\section{Meadow and Mountain}

secret. In the pioneer days the prairie boy saw the beauty and heard the music as he drove along the furrow.

He who looks for beauty and listens for music will be hunted of these wherever he goes. Those pioneer days were all athrob with coming conquests. The plow behind the oxen has been more civilizing than "The man behind the gun." It is better to leavé one's footprints growing green with wheat and corn than to leave them red with pools of blood. The plow, and not the sword, is the great symbol of civilization. It is not more navies, but more navy beans that we need. Let us have more shooting corn and fewer shooting cannon. The plow sows harvests and scatters gold in the furrows that it makes. The song of the sickle is better than war songs.

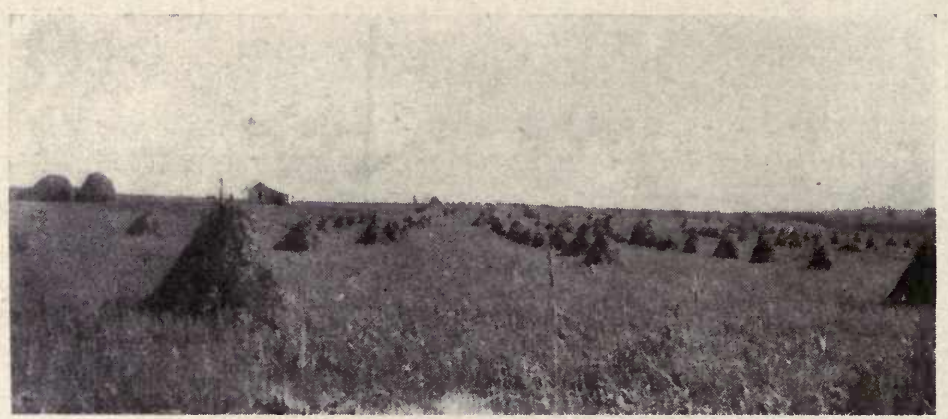




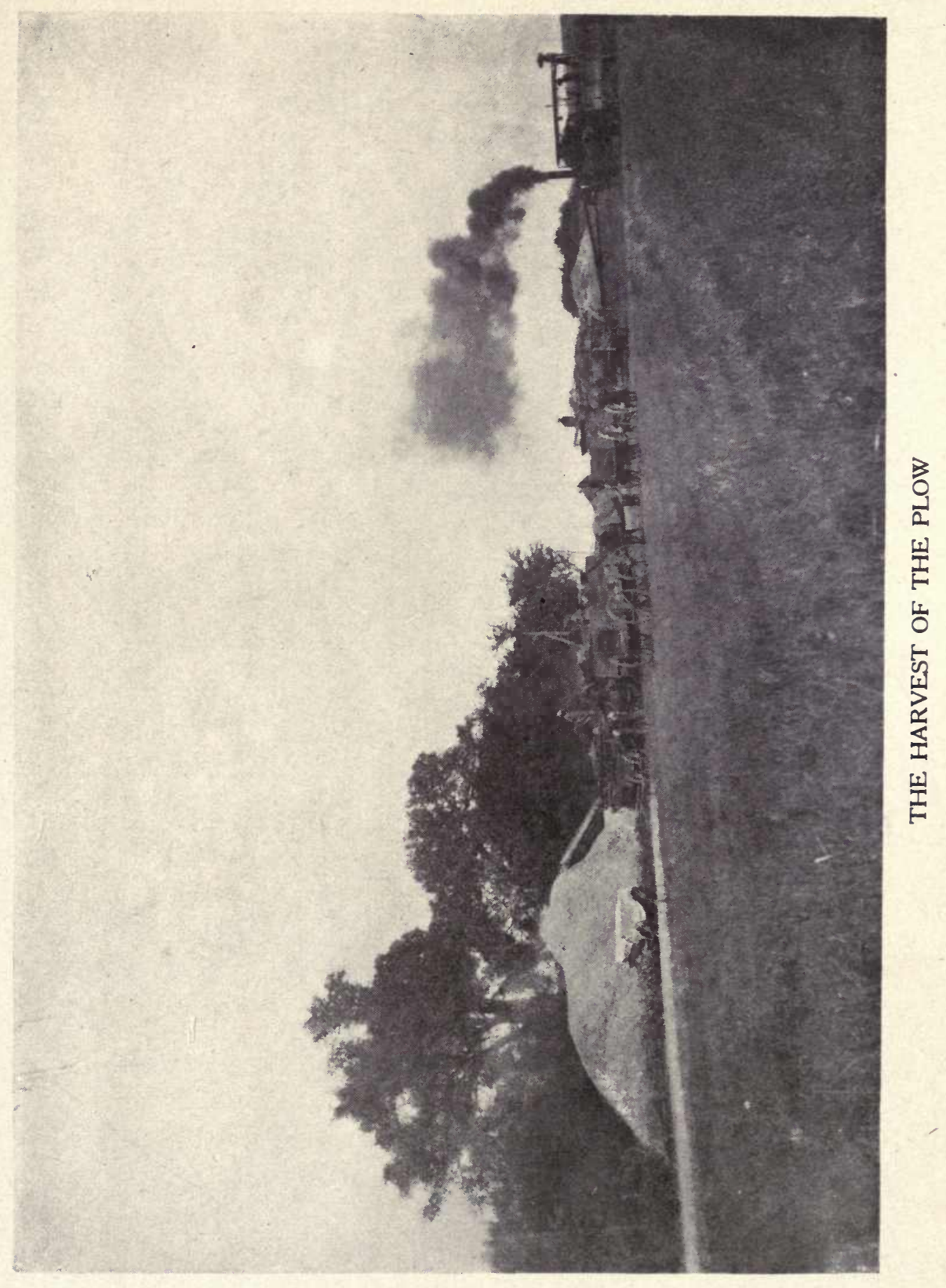


8 


\section{THE SONG OF THE SICKLE}

The odors sweet,

- Of the yellow wheat,

Are afloat on the morning air;

And the sickle's trill

O'er vale and hill

Makes music everywhere.

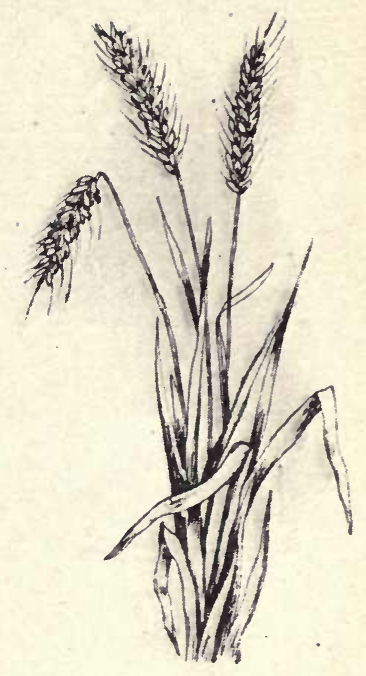

There's health and bliss

In the morning's kiss,

And the pulses throb and throng;

While music floats

O'er silver oats,

Where sounds the sickle's song.

The sickle's song

I would prolong,

Till war songs hush and die,

Till peace of mind

All men shall find

Under the harvest sky. 


\section{Meadow and Mountain}

See, the plowshare bites the soil, and the black sod-ribbon stretches along the furrow's side. But how did the blackbirds know when the first fresh furrow would be cut? There seems to be a consensus of opinion among birds as among men. And what errand has the robin so far away from home on this cool April morning? I venture to say that he knows his business. Yonder he goes, flying like the wind. Something hangs from his beak like a round, pink string. It is no string, but an angle-worm. And is the robin a fisherman? How does the worm enjoy that swift ride in the cool air? He never came back to answer the query. He was taking his turn in a tragedy. Some nude little robin will fly the better when fledged for having eaten that worm. It made a rich feast in the mud-made nest among the apple blossoms. When the birdies and blossoms have flown away, and autumn leaves are falling, and while the apple trees are holding many an empty nest, I will fill my baskets with winesaps and pippins.

But the larks are the epicureans of the prairie. The cock-lark is a yellow-vested philosopher. The larks know that the fattest feasts are in the soil. The best things are generally invisible till some plowshare turns them up. The feathered folk seem to understand that use of the plowshare. The lazy man never learns that secret. The lark sings between meals. That is well. It is one reason why he can eat so many meals in a day. The spirit of song is a great digestant. Ditties and dyspepsia are not congenial. All day long the lark follows the furrow with as blithe a whistle as was ever blown from the pursed lips of a prairie boy. They both are lyrists, and life is glad for them. The lark is a philosopher. He is industrious, courageous, cheerful. 


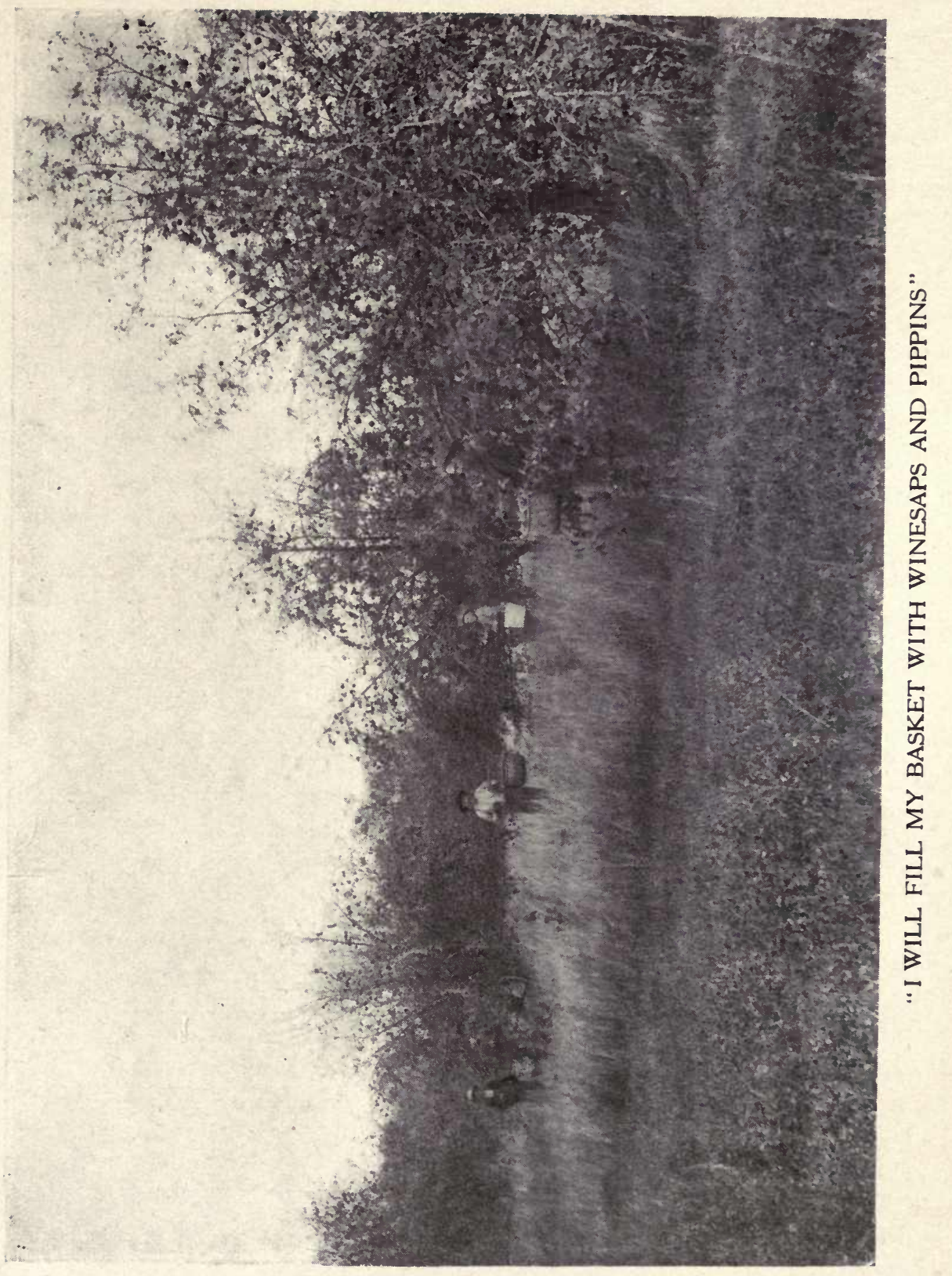




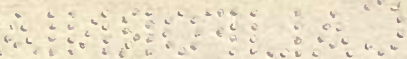




\section{The Fruit of the Furrow}

And those are the three notes in his song that make its music.

I knew a pioneer who had learned the lark's song. I am about to say a word concerning his farm. He built his cabin-home under the cottonwoods. They were landmarks that could be seen from far. In winter they broke the blizzard's breath into long-drawn sighs. In early spring their waxen plumules adorned the naked boughs with greenery that glistened in the sun. At summer noontide their fullspread leaves threw cooling shade on the cabin roof, and many a bird with parted beak and hanging wings cooled itself in the shadow. The glossy leaves of the cottonwood fluttered in every vagrant wind that wandered across the prairies; and then, like whirling flakes of yellow snow, fell at autumn time in leafy drifts about the cabin door. To all this poesy and beauty the pioneer's eyes were open.

But years slip away more swiftly and silently than do leaves from the trees, and the toil of the plowman is rewarded at last. Where the plowshare first cut the virgin soil are vineyards, orchards, and fruitful fields. The grapevine's foliage literally covers and hides, with its drapery of green, the supporting tree. In the foreground of the vineyard is beauty, though not of tree or vine, whose charms would captivate the most callous man alive. No man foresworn to bachelorhood would dare to linger amid such scenes. Beauty, youth, and spring-all breathe in unison. One's blood will flow the better for being much among them. 


\section{Meadow and Mountain}

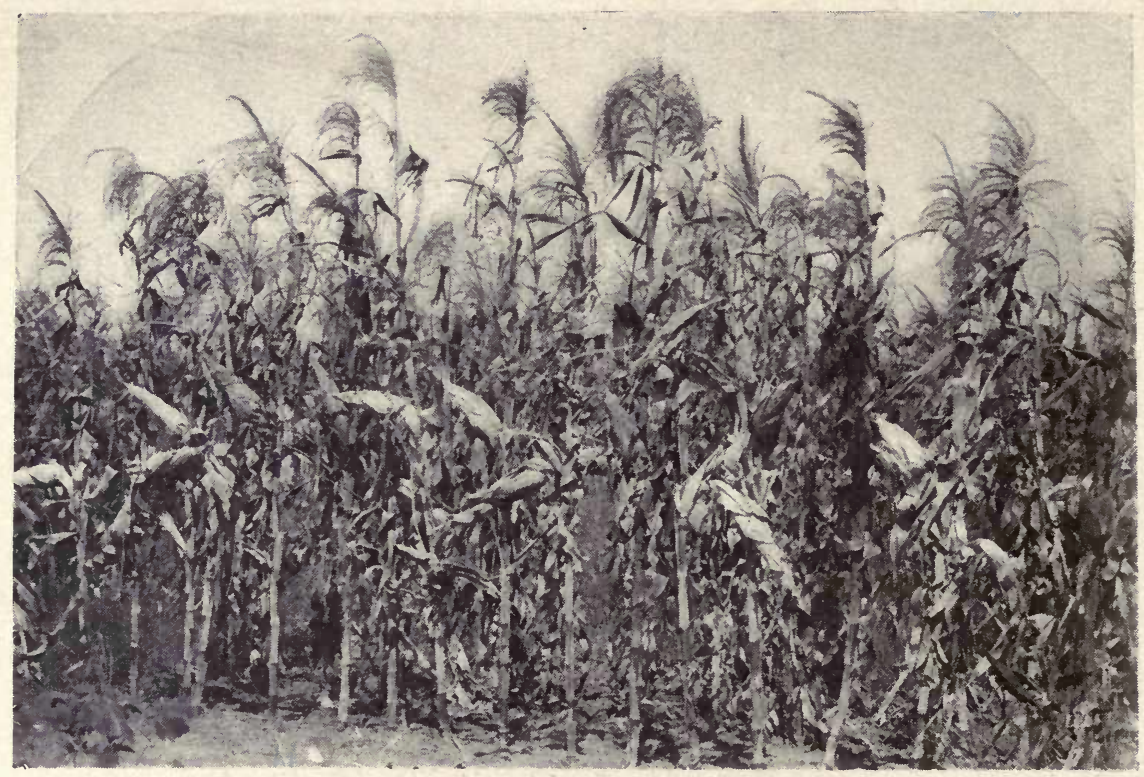

"MAIZE IN FULL TASSEL"

The farmer's fields are the fruit of the plow. Few flowers are more sightly than maize in full tassel and silk. The comely curves and deep-green of its leaves, the tassel, full-hung with tiny and pendant flecks of bloom, and the husk-hidden ear with its tender and beautiful silk-these are a sight worth any one's seeing. No distiller of perfumes has quite caught the corny-scent that flows from such a field when wind-blown. It is good enough for the gods. There is a pleasing, reminiscent atmosphere that hangs about a shock of corn. It piques the memory and minds you of summer showers, fragrance, and sunshine. Then, when the corn is husked, to see the hopper piled above the rim with great, white ears - that is a sight that gladdens the heart of man and beast! Wait a little, and you shall have hoecakes, corn-pone, or batter-cakes, according as you like. 


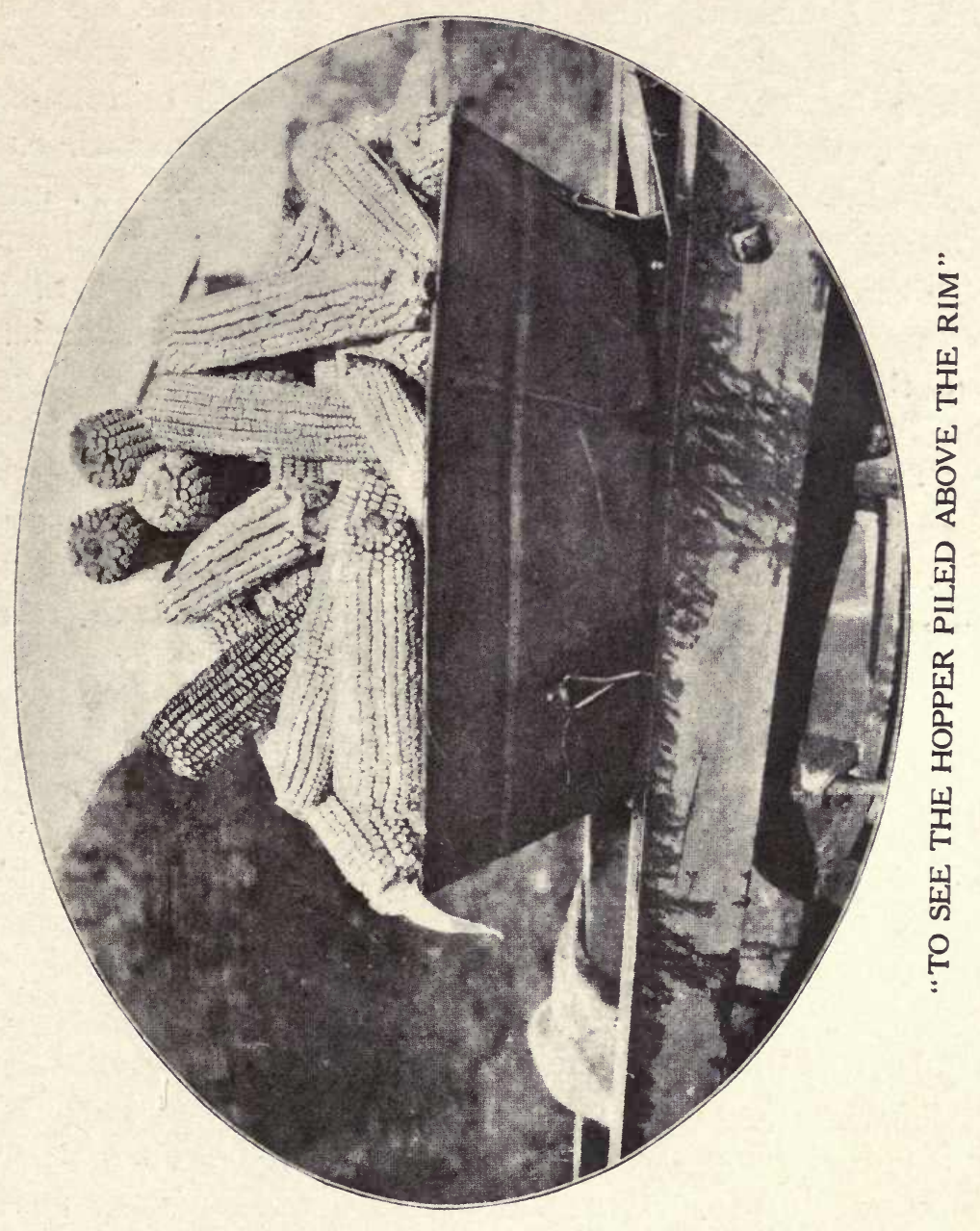




\section{Meadow and Mountain}

A wheat field is beautiful from the moment it stands fresh and green in the drilled rows in autumn till it is gathered in ripe, yellow sheaves in summer. The wind-made undulations that billow across an uncut field of full-grown wheat are as beautiful as a sun-lit sea in summer time. It is idle for him whose eyes fail to catch the glory and summer sheen of that apocalypse to visit any of the world-famed galleries. Beauty appeals in vain to sightless eyes and sightless souls. Not even a shadowgraph can be silhouetted on nothingness.

There is no doubt that folks were happy in the olden times, but people differed then as now. Some were sordid then. Some are sordid now. Then some were sightless. But some to-day are blind with eyes wide-open. Some eyes saw beauty then, and some see beauty now. The world has never been without its seer. It will never be.

The plow is the symbol of conquest and progress. It stands for wealth and weal. Its beam points to the glad future.

\footnotetext{
"Out of the shadows of night, The world rolls into lightIt is daybreak everywhere."
}

In the furrow of the plow trails the poesy of beauty. Orchards with bloom-freighted boughs in the springtide and fruit-laden boughs in the autumn. Vineyards of tangled vines and purple grapes spring from the loam that the plowshare cut. Wheat, oats, corn, and grasses, fallen in new-mown hay, yield their harvests in the path of the plow. The coming morrows will be better than the yesterdays. Beauty is ancient, but her forms may be modern. Let us not miss 


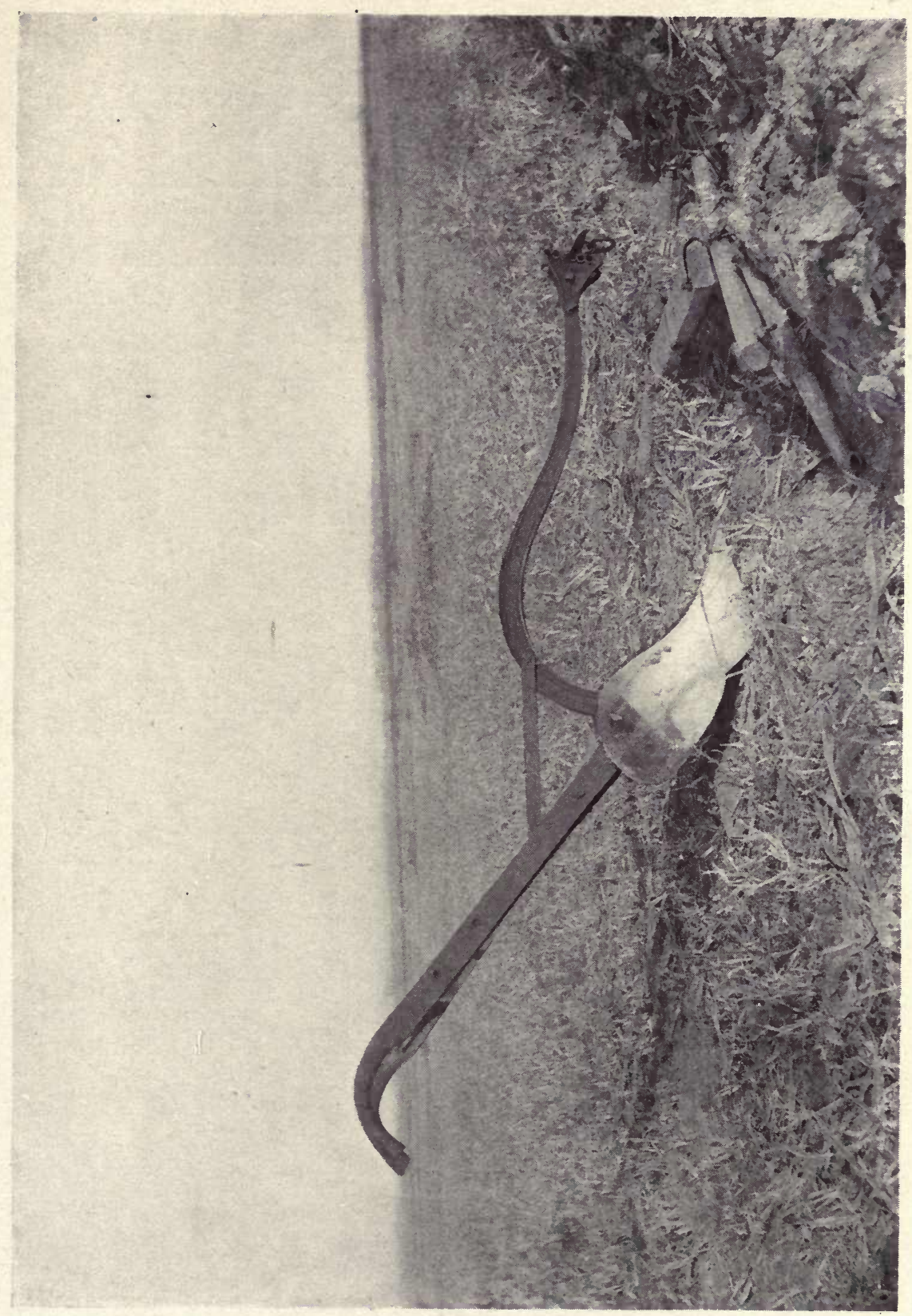

는 


\section{Meadow and Mountain}

her newer lines. All honor to our forebears who went in the way of her shining feet. They hastened the dawn of the better day by the midnight music of the "spinning wheel." Let that holy heirloom stand in the modern home as the serene symbol of thrift and truth. And let it mind us of that unseen Weaver who "clothes the grass of the field," and who will also clothe and care for us.

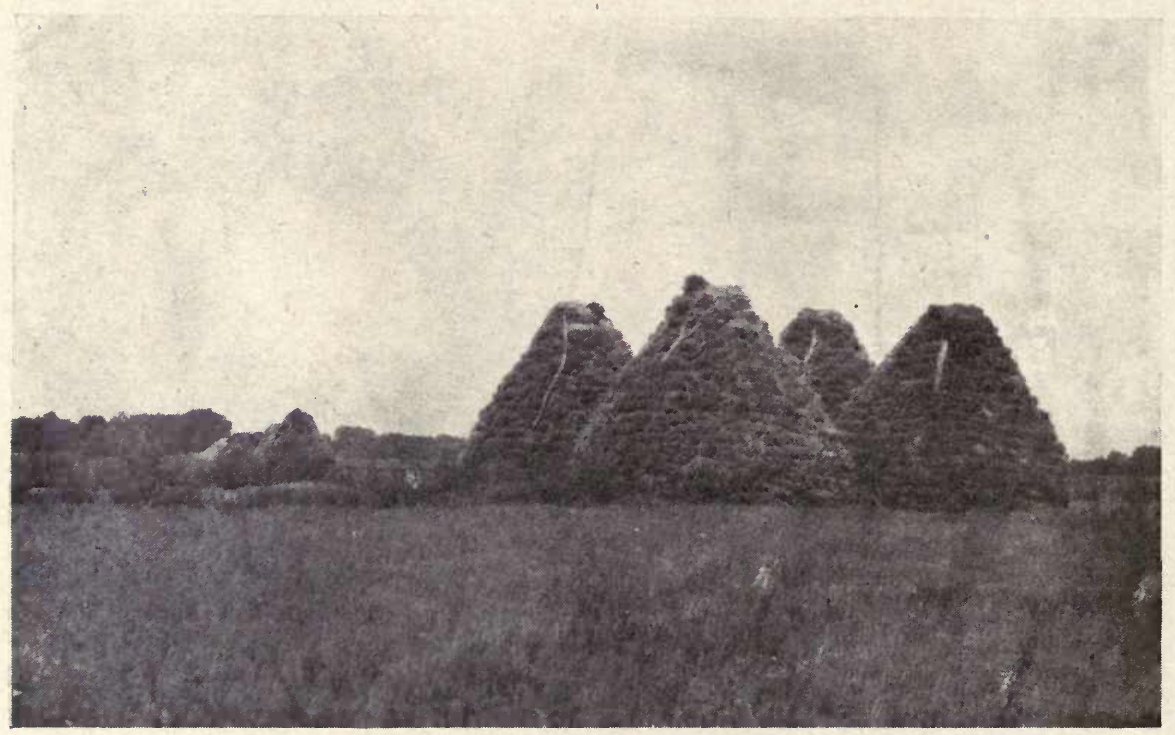




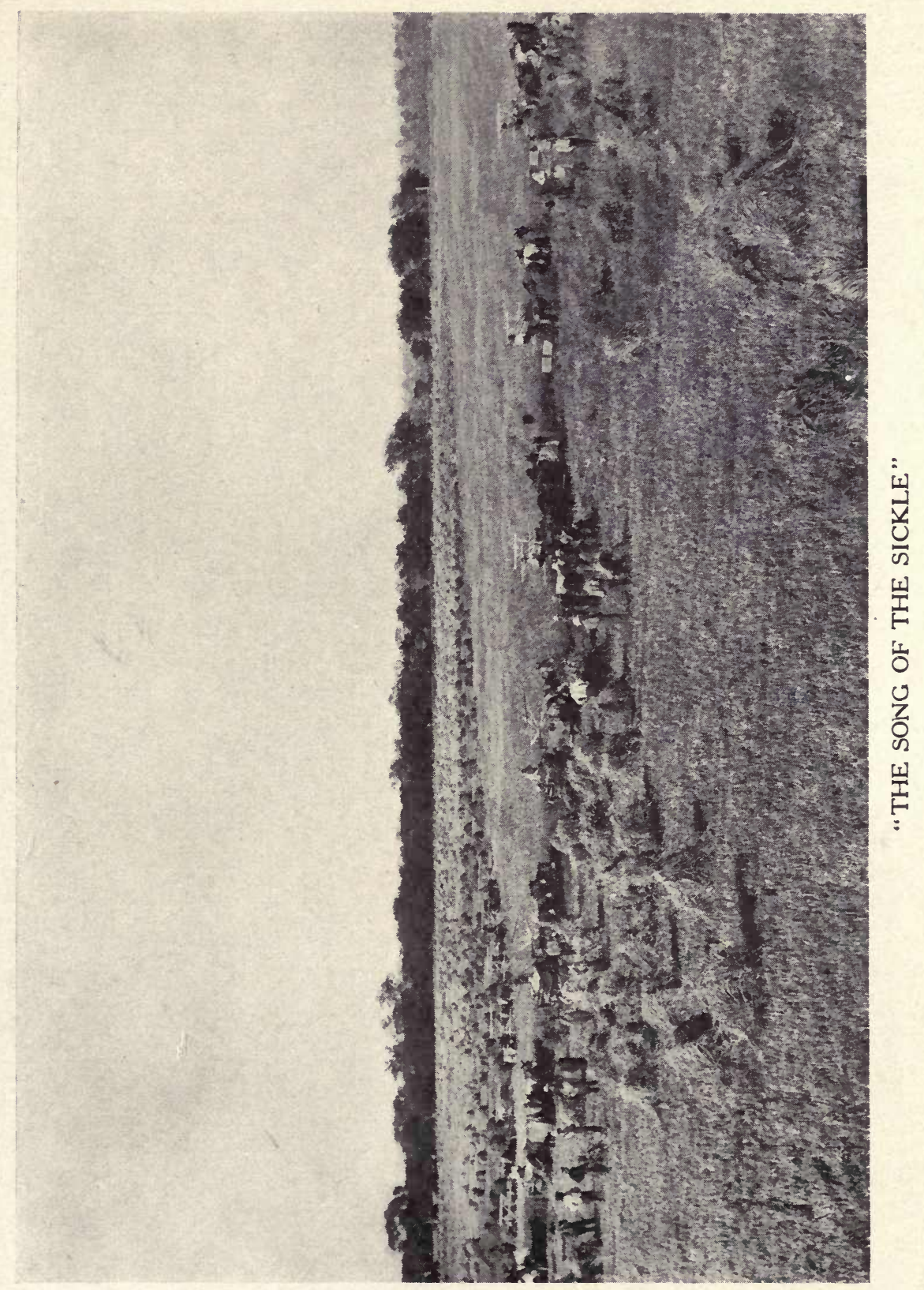





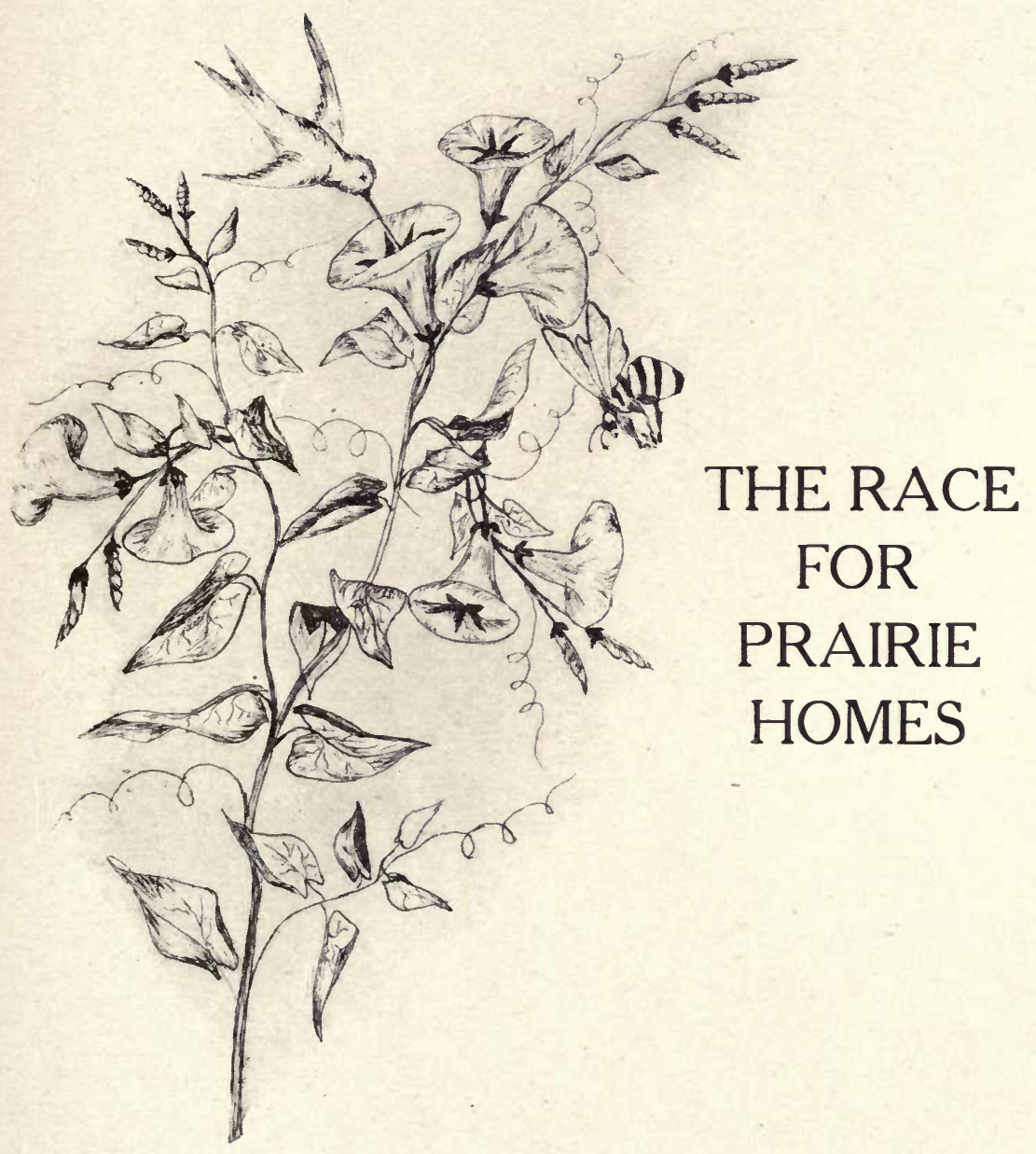


\begin{tabular}{l}
$\cdots$ \\
$\therefore$ \\
\hdashline
\end{tabular} 


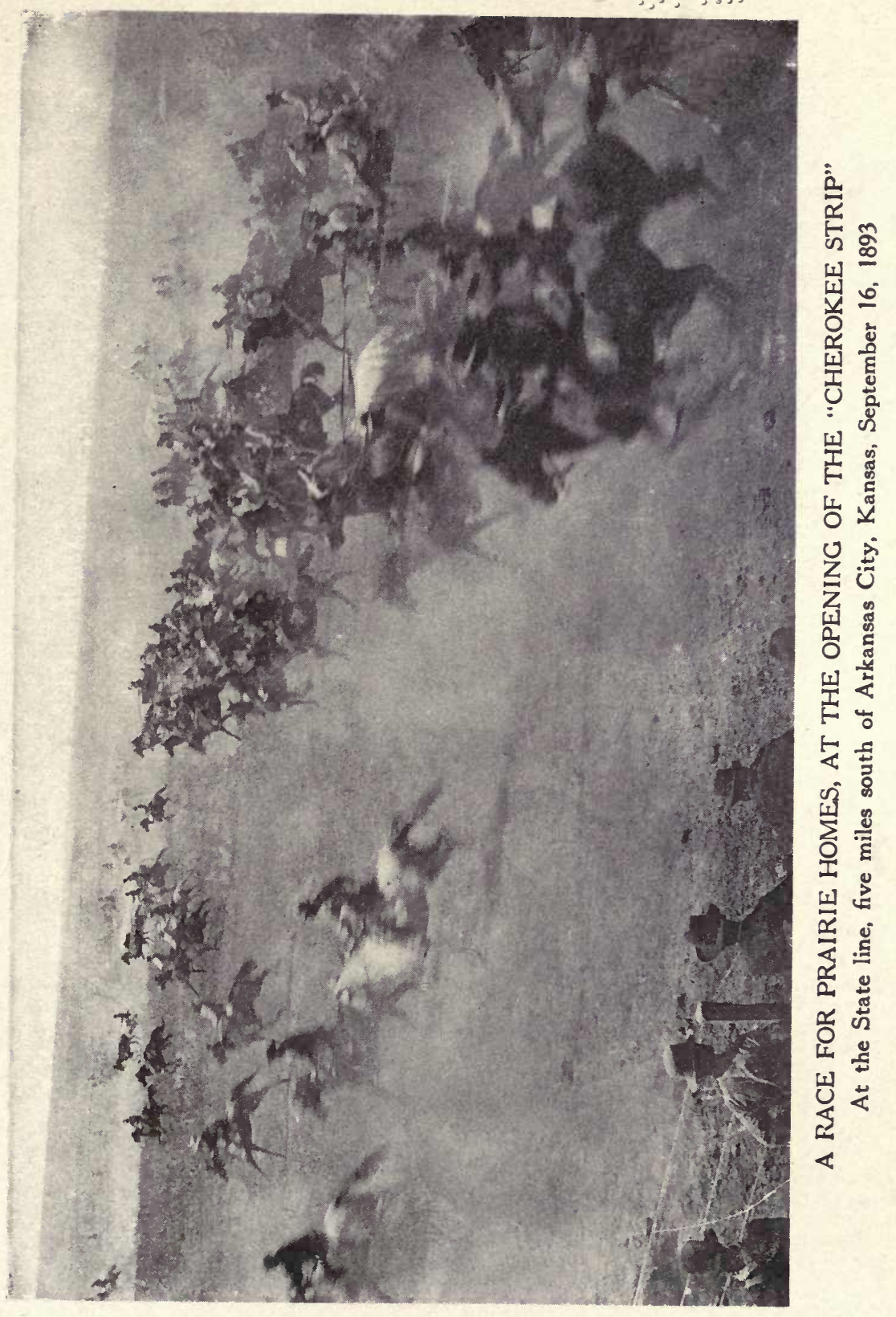


$\because \vdots \vdots \quad \vdots \because \vdots \vdots \vdots \vdots \vdots \vdots$

$\therefore \vdots \vdots \because \because \because \because \because \vdots \vdots \vdots \vdots \vdots \vdots$ 


\section{THE RACE FOR PRAIRIE HOMES}

IT was September 16, 1893. Had the dust been powder, it would have flashed in the flames of the autumn sun. For many weeks not a drop of rain had fallen, and the wind rolled over the prairies like the breath of a furnace. The dust around the registration booths where the hundreds of weary home-seekers had waited for days and sleepless nights was ankle-deep.

But the time came when the last name was registered. Then the eager multitude began to shift into position for the race. It must be an even start from the State-line. Footmen, horsemen, and occupants of all manner of conveyances shuffled into position side by side. They had come from east, west, north, south, from far and near, and from every walk in life, all "dreaming of home"-and now the hour of destiny was about to strike. A Government soldier was leisurely riding his pony toward a knoll in the coveted country about a half-mile away. Every eye followed him, for at the boom of his gun the wild race would begin. He is now at the knoll. The signal gun is lifted. A little cloud of smoke is seen blown from the muzzle of the soldier's gun, and away the runners fly. Men, women, and horses go like the wind for the goal. Vehicles break, horses fall, riders are thrown. But many are marking the nearby claims, and others speed on to the lands along the river, and on the other side, "Home, sweet home!" 


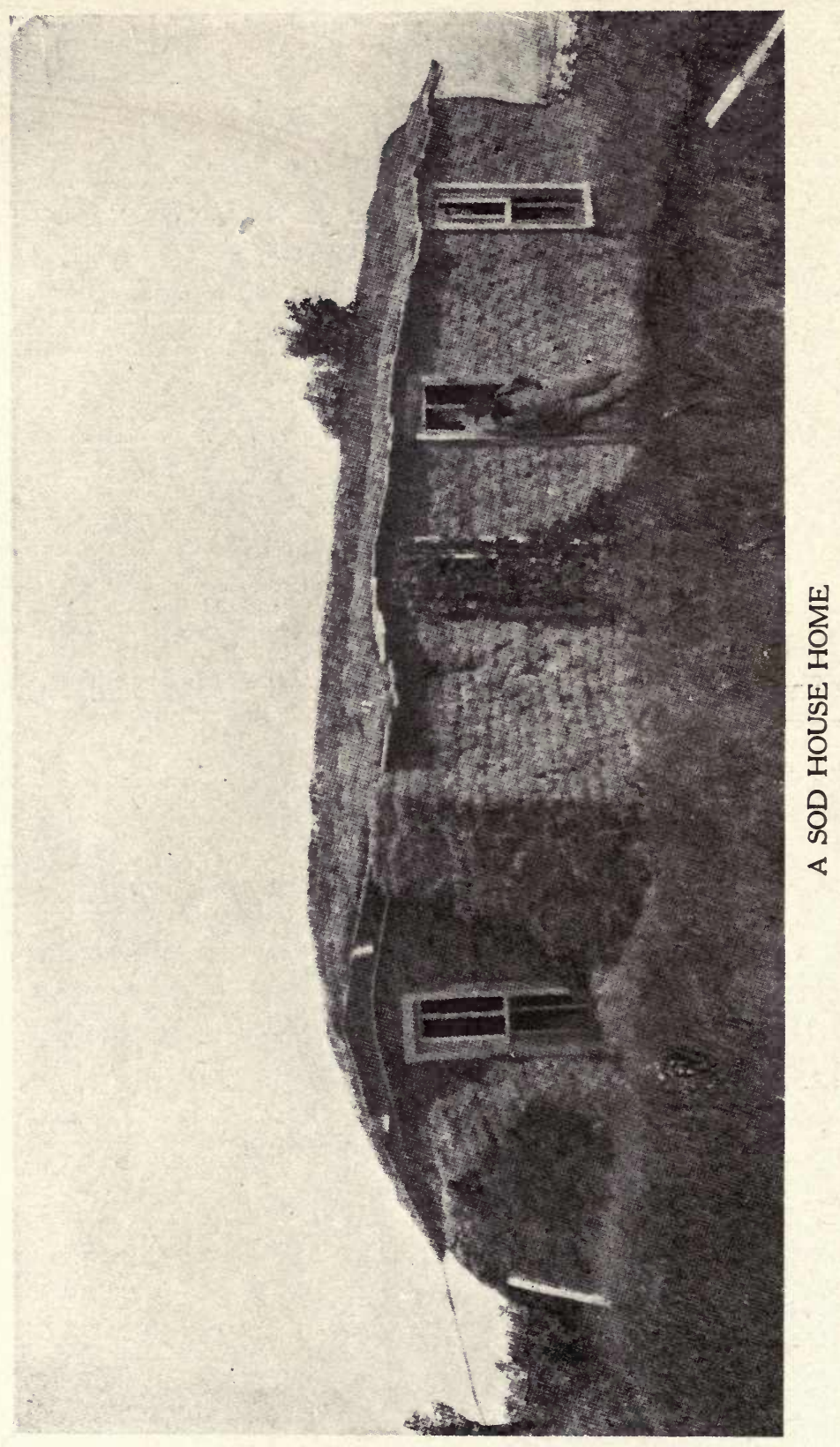




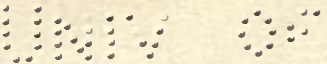

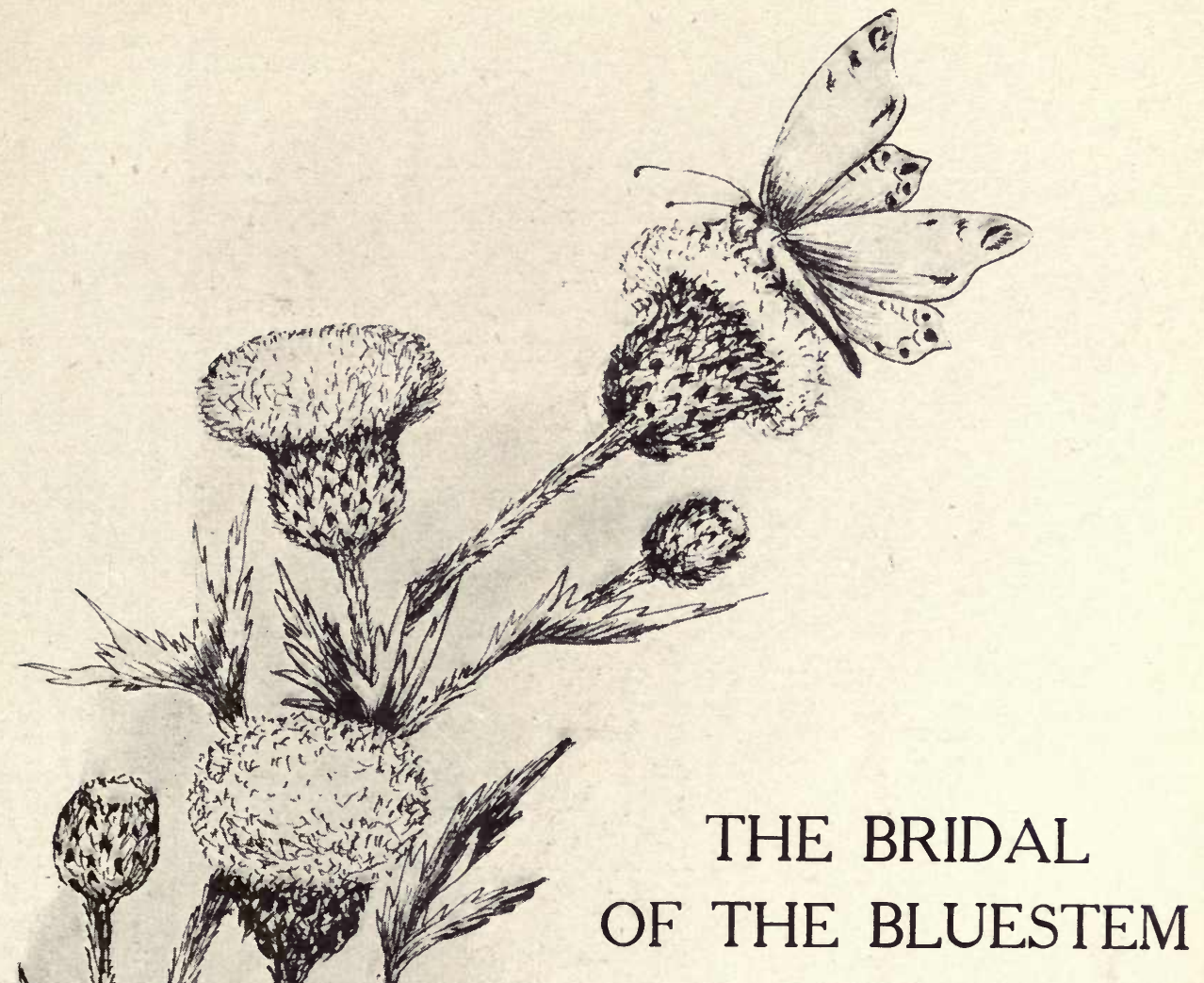



$\because \vdots \because \cdots$

$\therefore$ ํ. 


$$
\begin{aligned}
& \text { 舟 } \\
& \text { 的 }
\end{aligned}
$$

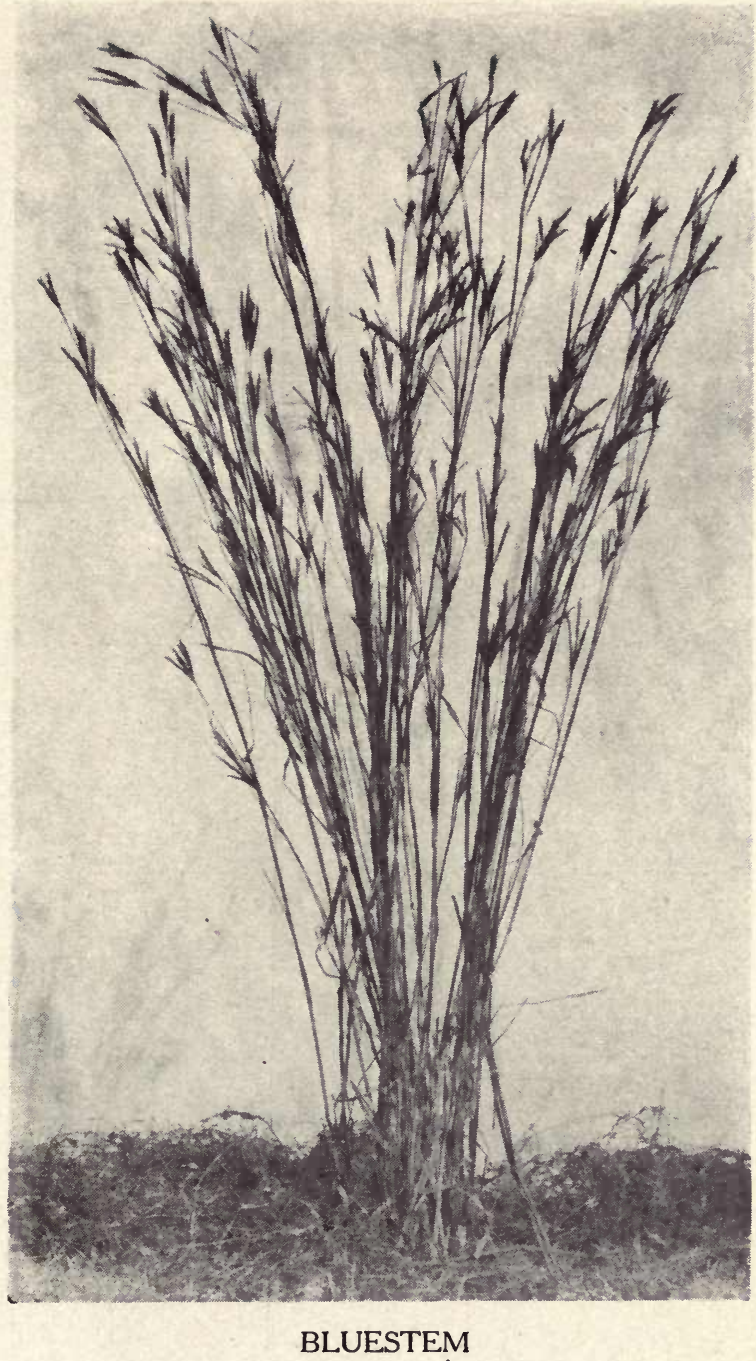


$\because y^{\circ} \quad \because 200$

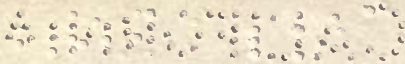




\section{THE BRIDAL OF THE BLUESTEM}

BLUESTEM had grown tall and handsome on the prairie. He towered high above his brothers of the grass. You would think him feeble to see him bend before the wind. But he had learned to bow to the will of the wind and not break. He had learned that struggle develops strength. He always stood as stiff as he could when the wind began to blow. But the sight of ugliness pained Bluestem to the heart. He yearned for the companionship of beauty. On a day in April, when he was very young, he caught a glimpse of her face and saw her trail across the prairie. She moved past him as noiseless as a shadow on the grass. Every day and night when the wind blew by he whispered the name of Beauty. All of his grassy friends noticed that the more Bluestem longed for beauty, the more beautiful he became. But he grew taller the while, his very longing seeming to lift him. Now and then he seemed to hear her singing in the wind, and, spreading abroad his grassy palms, he would feel about to find her. He had set his heart on Beauty, and that had made him beautiful. To Bluestem's ears Beauty's faintest footfall was music. To his vision her face was an apocalypse. Bluestem's eyes are clear and keen for no eyes see like the eyes of love.

One day in May, while Bluestem stood waiting on the sod, he saw a long raceme shooting up from the center of a tuft of dagger-pointed leaves. This beautiful thing was draped about with many snowy blossoms. Beauty had long stood by Bluestem's side awaiting him to woo her. All the 


\section{Meadow and Mountain}

while she had been concealed by the green dagger-points that stood around her. Had he been less fearful of the daggerpoints he might have found her sooner. But Yucca is Bluestem's bride, and he is far more kingly since this queen gave him her beauty. If you listen you shall hear a sonnet singing in the summer wind. Could Bluestem be the sonneteer?

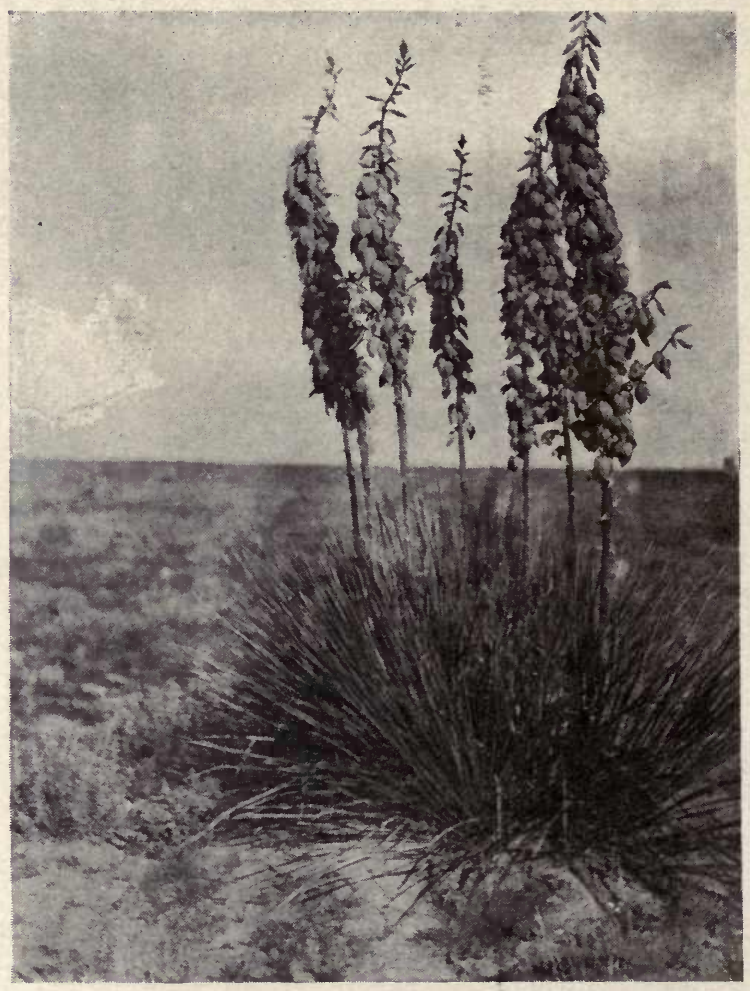

YUCCA 


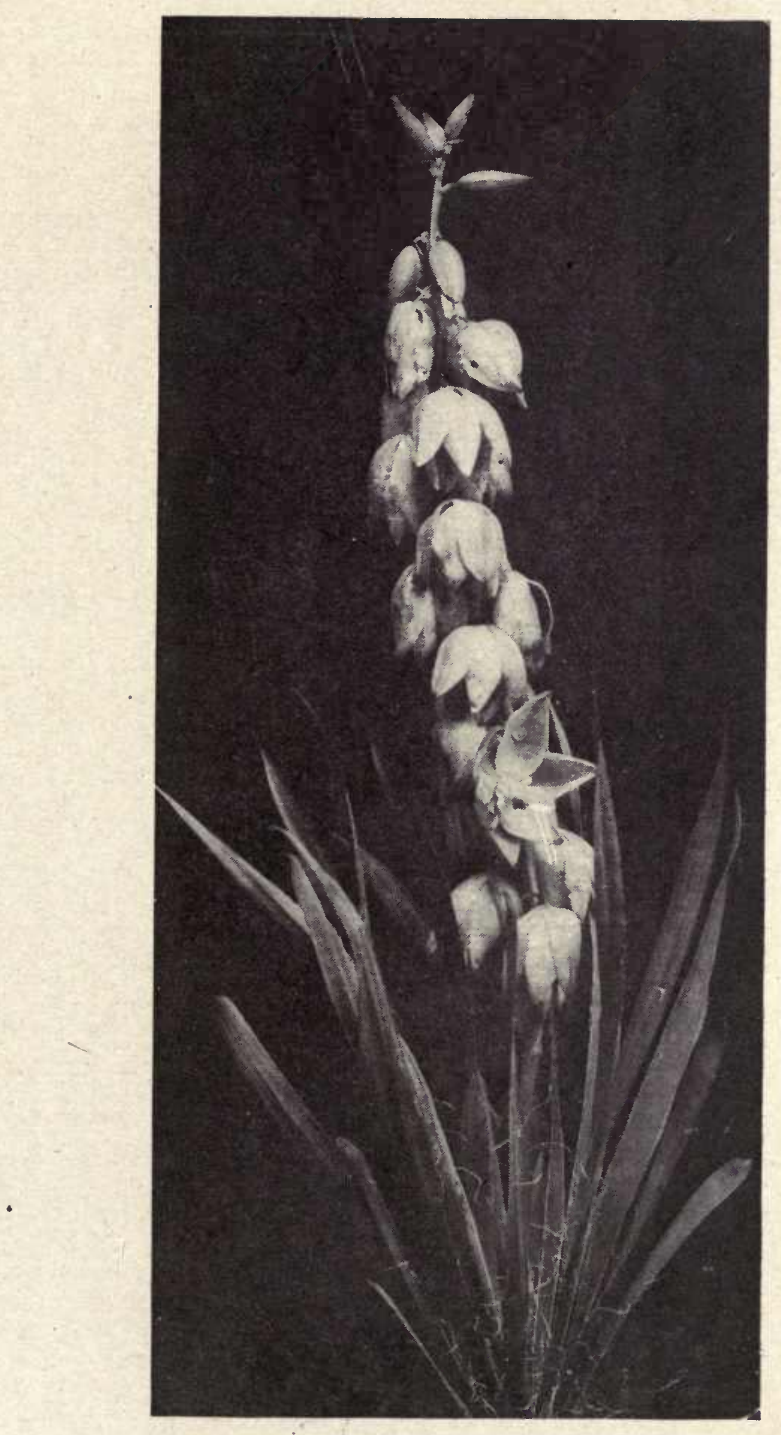

"DRAPED ABOUT WITH MANY SNOWY BLOSSOMS" 


\section{Meadow and Mountain}

Fair Queen of the Prairie, thy snow-white flower,

Spire-like, points to the sky;

Above the green turf thy blossomy bower

Delights the lone traveler's eye.

Spring showers have nourished thy life into bloom,

Autumn will spoil thy glowing raceme,

Winter will shroud thy verdure with snow,

Bury thee, living, in frost-made tomb,

Under the drifts to slumber and dream,

Over thee blankets of snow will gleam,

And the bright frost-flowers will blow.

Bluestem ceased singing and looked to see if Yucca smiled. But the fair, white beauty had fled. Wondering, he waited for her return. Many a time before she came he thought he heard her footfall. One sultry noon he thought he found her footprints in the swale. Then once he thought he saw her playing hide-and-go-seek with some one in the evening gloam. Once at midnight he was sure he saw her in the moonlight, bathing her hands and feet in the dew.

It was sunrise when Bluestem awoke and found at his side a lovely form. Beauty had returned, but robed this time in golden-yellow. He threw his sheltering shade upon her, for well he knew that the hot sun would soon spoil her shining dress. As they stood side by side in the sun, a prairielad passed, taking some kine to drink in the draw. Listen! $\mathrm{He}$ is singing

\section{A SONG OF THE PRIMROSE}

Dainty Primrose, shy and furtive.

Thou art timid, yet assertive, And a scepter thou dost sway, Halting travelers by the way. 


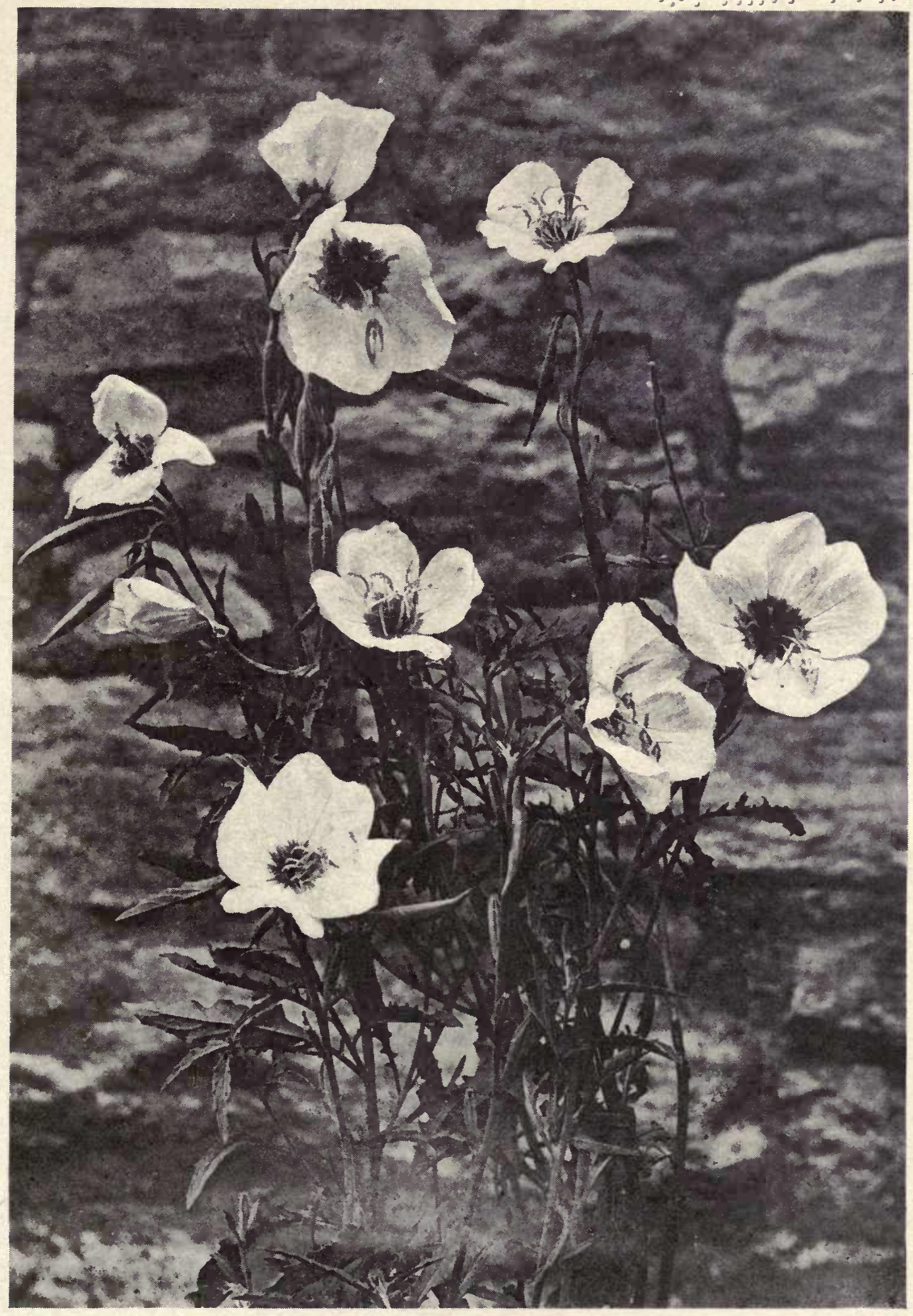

PRIMROSE 



\section{The Bridal of the Bluestem}

Gleaming beauty of the morning, Prairie trails and fields adorning, Must thy beauty sleep so soon, Hiding at the summer noon?

Come back, Sweet, when in the gloaming Spangled skies are overdoming;

Then when none but angels see,

Primrose, I 'll keep tryst with thee.

As the last lines of the song died in the distance, Bluestem found himself again bereft of Beauty, save what his own heart had caught from hers. In place of her garments of bloom, there lay at his feet, curled up in the grass, nothing but faded and withered petals. He was sad but not disheartened, for living with Beauty had made him brave.

On a warm summer day, as he stood with head bowed in the wind, and dreaming of the past, he was delighted to see a thorny little vine at his feet. It was covered with tiny and sensitive leaves. They shrank from his softest touch. Here and there among the leaves were lovely little blossomballs. These were covered with innumerable hair-like petals, the outer ends of which were tipped with tiny bits of pollen as shining as the dust of gold. Beauty had come this time in the strange disguise of the Sensitive Rose. As her pink and green gown trailed about Bluestem's feet, he smiled upon her and sang this whisper-song:

$\mathrm{O}$ passionate, sensitive rose,

As round as a sprinkle of rain

That fell from a garden of cloud through the air, And bloomed on a warm window pane; 


\section{Meadow and Mountain}

Thy fragrant and crimsoned-hued ball,

And tresses all tipped with gold,

Are as soft as the sunbeams that sift through the air,

And the essence of beauty they hold.

A thorny wee vine in the grass

Feeds life to the sensitive rose,

And the lover-like sun, with tender caress,

Her ravishing color bestows;

The fine and fern-like leaves

Are startled by touches of man,

No passionate lover would dare to embrace,

But onlv her beauty to scan.

The love-guided fingers of God

Imprinted her there in her place,

And torn from the motherly breast of the soil,

Life's glow fades swift from her face;

O Beauty has many a form,

And garments of many a hue,

But she lingers to greet her lovers who seek

Her haunts in the flowers and dew.

But Bluestem's eyes soon again lost sight of Beauty. While he sang she seemed to slip away. He was as sensitive now as the sensitive brier. The bloom had fled, but the tiny thorns remained. In Bluestem's world of beauty he often found bee-stings and thorns mixed with the honey and the blossoms. This puzzled him, but he found no answer on the prairie to that puzzle. "Blossoms and thorns, honey and stings - that mixture would perplex a philosopher," so said Bluestem, as he sobbed in the wind. Then he left off puzzling, and looked again for Beauty. For she had come back to him as often as she had left him. She had delighted him as often as she had disappointed him. She left him 


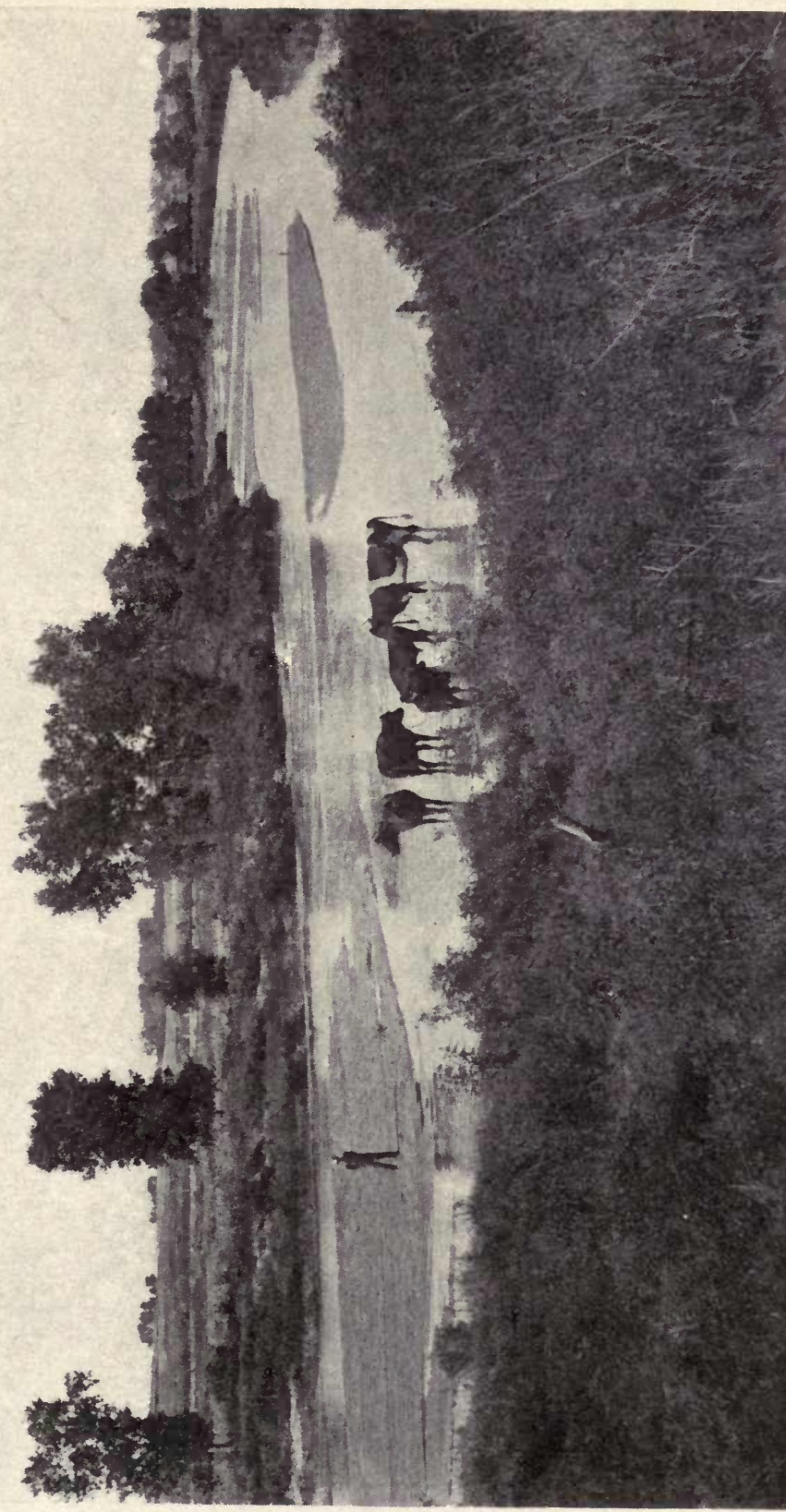

紊 



\section{The Bridal of the Bluestem}

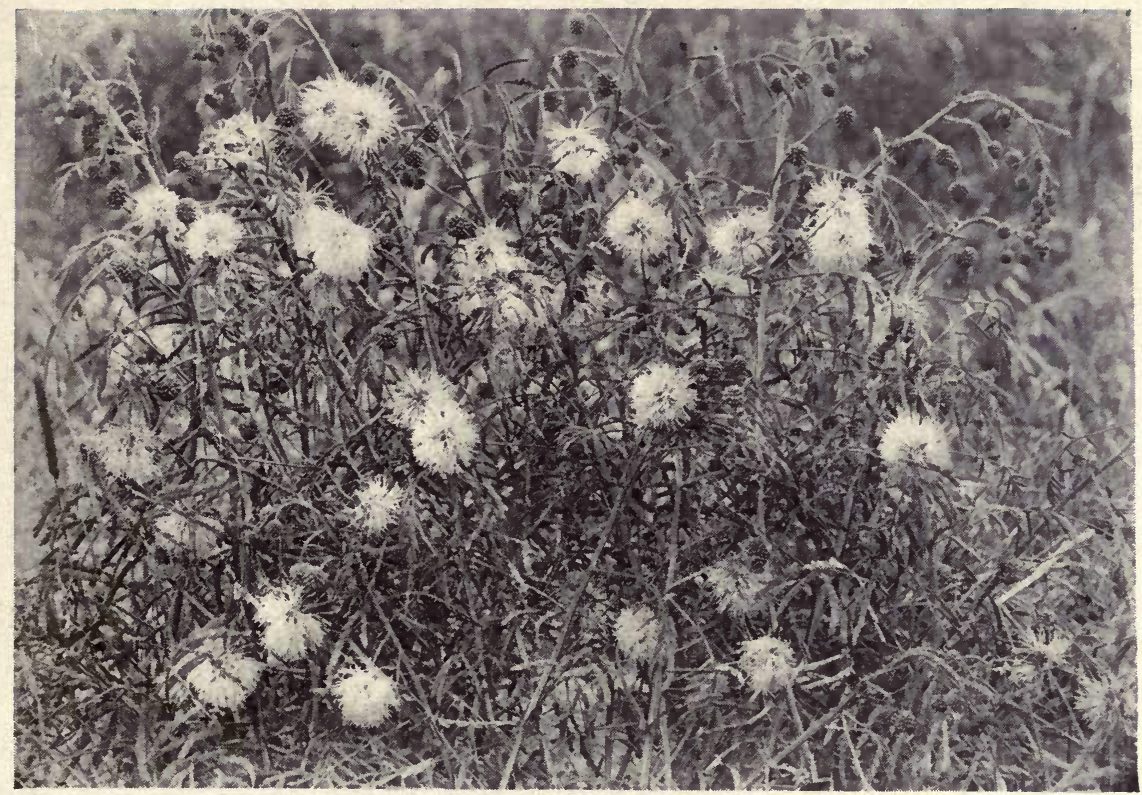

"A thorny wee vine in the grass

Feeds life to the sensitive rose."

sometimes till he was almost starved, but he enjoyed the feast all the more when she returned. Albeit, he could not live long without her. He was willing to pay any price to possess her. But the prairies looked dreary now without the sight of her. Bluestem looked and thought he could see in the dim distance a ranchman mowing grass in the draw. If Beauty was hiding in the hay, would the ranchman's sickle wound her feet? Would the hard-hoofed horses trample on her robes? Such were the unspoken queries of Bluestem's love. He shook his head doubtfully as a gust of wind dashed-by. Far away he seemed to see something that resembled tossing plumes. Was it the vanguard of Beauty? Would she soon return? No other question could be of moment till this found answer. He would not wait. He 


\section{Meadow and Mountain}

could not. He fell asleep and dreamed that Beauty was at his side. He had found her in the draw, where the newmown hay lay wet with the dew. He marveled at the brilliancy of her gown. "Blazing Star" was the name it bore. It was like a purple plume, and was covered with scarlet star-shaped flowers. The stars of the heavens were not so attractive to Bluestem's eyes after he had once looked on this Blazing Star of the world. But the sun was high when he awoke next morning, and the first sound that fell upon his ears was the song of the sickle, mingled with the ranchman's song. Bluestem did not stir till the song was finished. And this is the ranchman's song of the Blazing Star, which he called "The Purple Plume:"

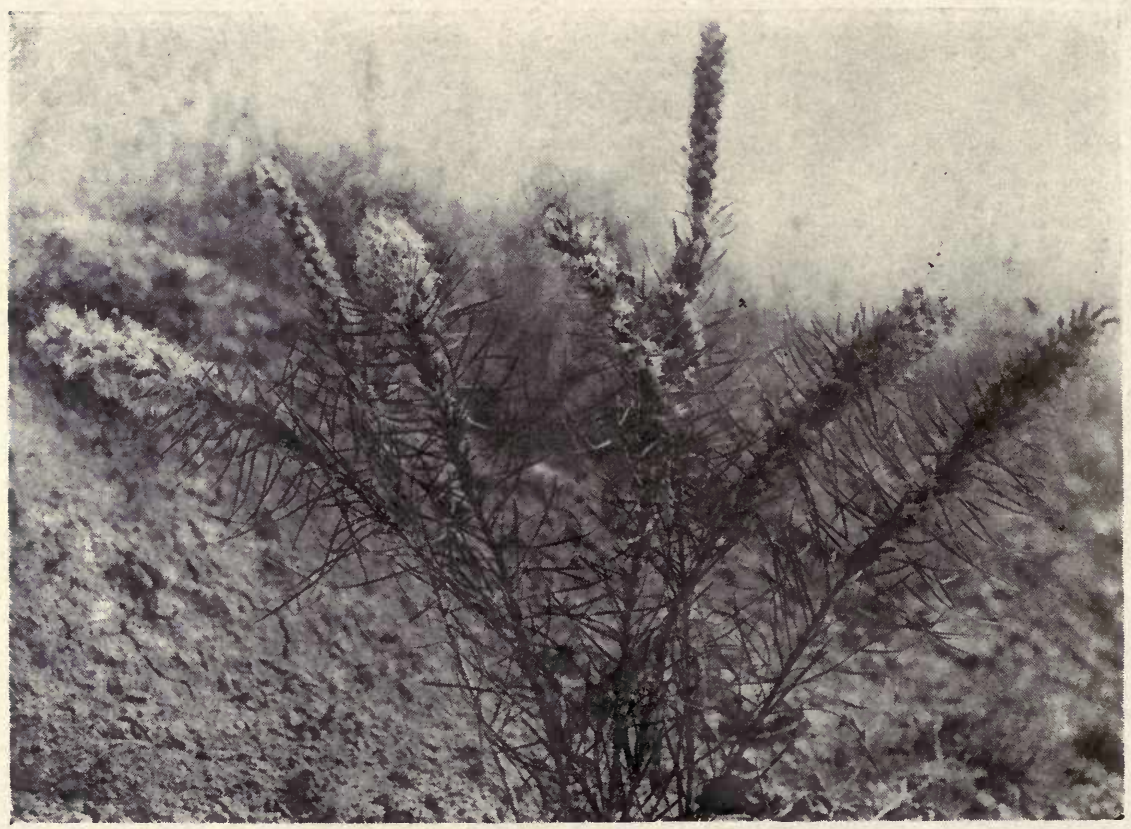

THE BLAZING STAR 


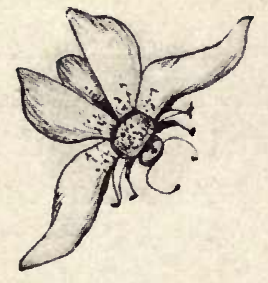

\section{THE BLAZING STAR}

O purple plume,

Amid the gloom

Of prairies wide and wild,

I joy to see

Thee smile on me,

As when I was a child.

On new-mown hay,

One summer day,

I saw thee prostrate lie;

The sickle's blade

A wound had made,

And laid thee down to die.

I saw thee fade,

Where thou wast laid,

The purple left thy bloom;

Then, with a cry,

A lark flew by

And sang above thy tomb.

But thy decease

Brought thee release

From storms and winter's woe;

And in the mow,

Safe sheltered now,

Art thou from wind and snow. 


\section{Meadow and Mountain}

Between the ending of the ranchman's song and the coming of evening dusk and dew seemed long and desolate. The prairie looked brown and unbeautiful. But the outer seeming much depends on the inner seeing. Night came with the sky clouded and moonless. Wan and weary, the stalwart son of the prairie fell asleep. At midnight chariots of cloud rolled their thunder-wheels across the sky. Stormwinds were unleashed and set upon the shelterless things that live on the unprotected prairie. Long spikes of rain gleamed like burnished steel in the lightning's glare. The hammer of Thor drove them aslant into the prairie's bosom. In the wildering darkness birds fluttered and screamed, with rain-drenched wings. Furred things crouched low in the grass. Cattle hurdled about in groups, and, bellowing piteously, backed against the pelting rain. Hail shot like icy bullets through the grass. Bluestem's garments were torn to shreds. If he had ever needed Beauty, it was in such a storm as this. But even with his tattered garments he fain would shelter her. Then he forgot his need in remembering hers. Once he thought he heard her call across the storm. $\mathrm{He}$ felt that he must find her. He was full of fear lest Beauty might be slain. Who, like himself, could give her adequate protection? Then he bethought him that a greater life than his was stirring in the storm. That thought filled him with good cheer. Then he recalled another voice, and it was musicful:

"Well roars the storm to those that hear A deeper voice across the storm."

The storm died at dawn. The rising sun shot a thousand gleaming arrows among the tattered bluestem blades. Though with tardy feet. Beauty came again. Standing in 


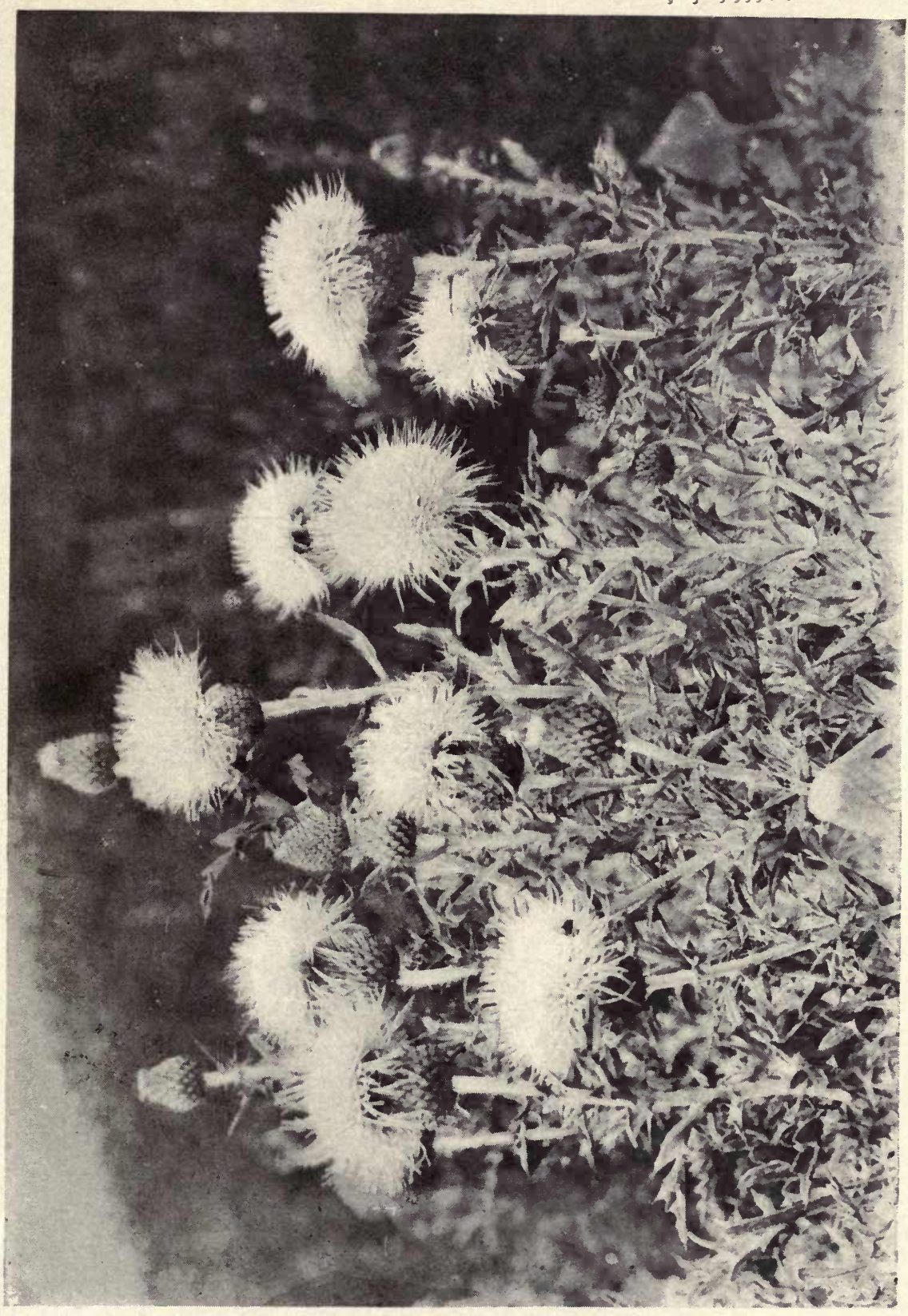

19 
$\because \because \vdots \vdots \quad \because \because \vdots \because \vdots \vdots$

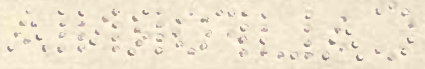




\section{The Bridal of the Bluestem}

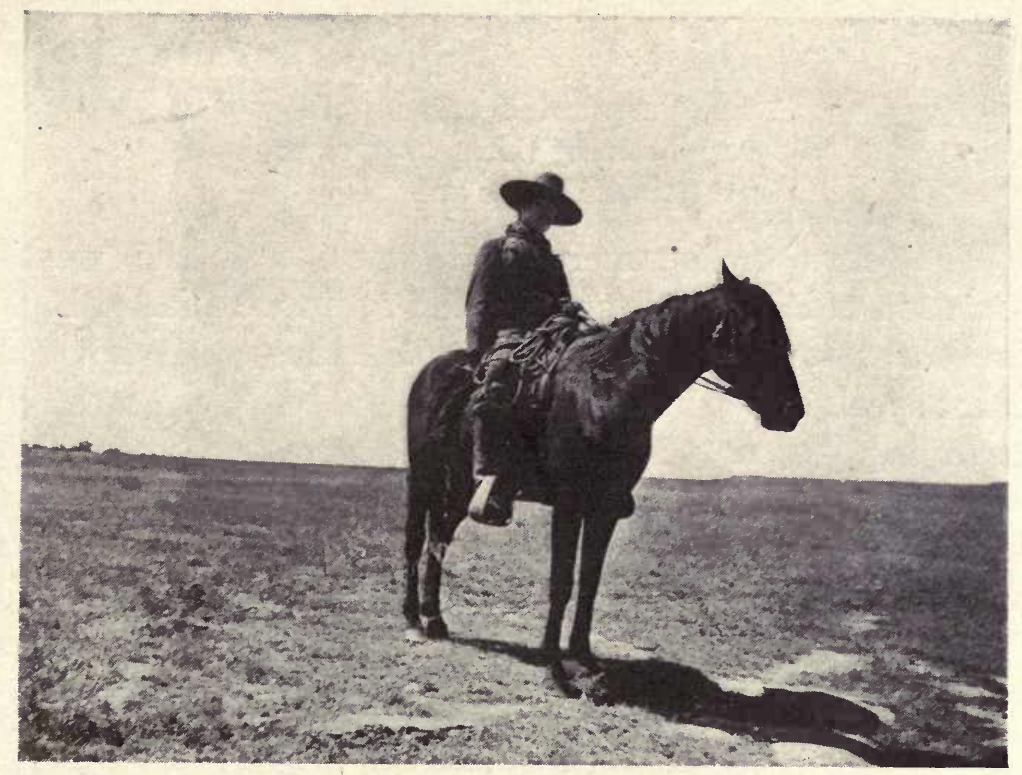

"UNDER THE OPEN SKY THE COWBOY SITS ASTRIDE HIS PONY"

the white light of the prairie noon Bluestem beheld her face. Her countenance looked all the fresher for the storm. The rain had filled anew the fountains where she drank and the morning dew had washed her garments dustless. She wore a thorny dress, but over it was spread a kind of silvery stuff, as if it had been sifted from the stars. Her tresses were of mingled lavender and pink. Her breath was sweet as orchards in the May-time. In search of prairie nectar, wild bees sipped the bloom of Beauty. Under the open sky the cowboy sits astride his pony and softly sings this flower song:

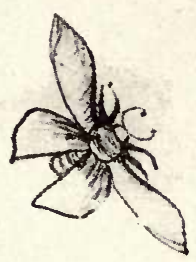

Softly blow, ye winds of June,

For I found this summer noon

Beauty sprung from out the ground,

Thorny thistle blossom-crowned;

Crest of lavender and white,

Golden finch and bees' delight;

Nodding like some prince's plume,

Gladdening prairie wastes of gloom; 


\section{Meadow and Mountain}

Singing winds are bridal bells, While the prairie bluestem tells Every listening thing that passes Of the thistle in the grasses.

The days of summer wore away, and the weatherbeaten son of the prairie stood alone again with faded Beauty pulseless at his feet. If any chanced to see her now, they did not speak of Beauty nor of bloom, but a voice on the wind was saying, "Poor Thistle Down." Bluestem was old and brown when autumn came. Yet he stood by all that was left of the beautiful thistle. Autumn plucked her tresses and flung them to the winds. Then he bowed himself, and a swift gust bore him away, and a voice that sounded echolike was saying:

Let autumn winds blow, And scatter the snow

For a winter of woe;

But together we go

To a summer we know-

To the land of the unsetting sun.

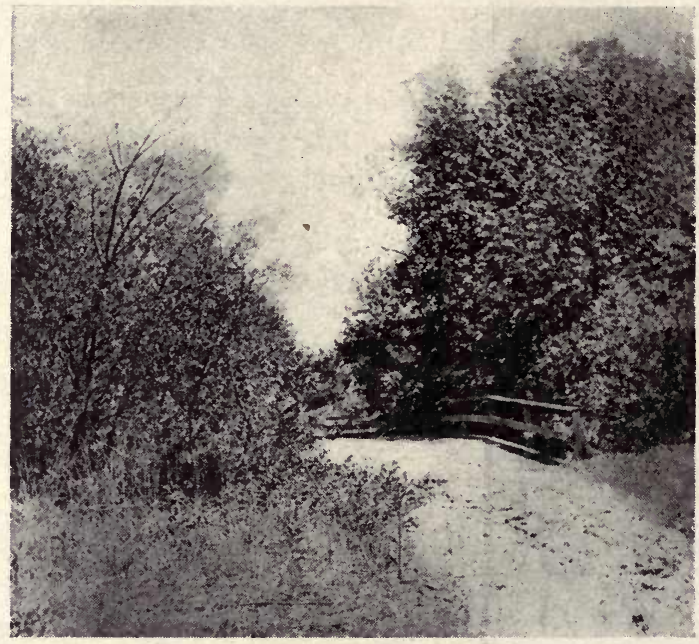




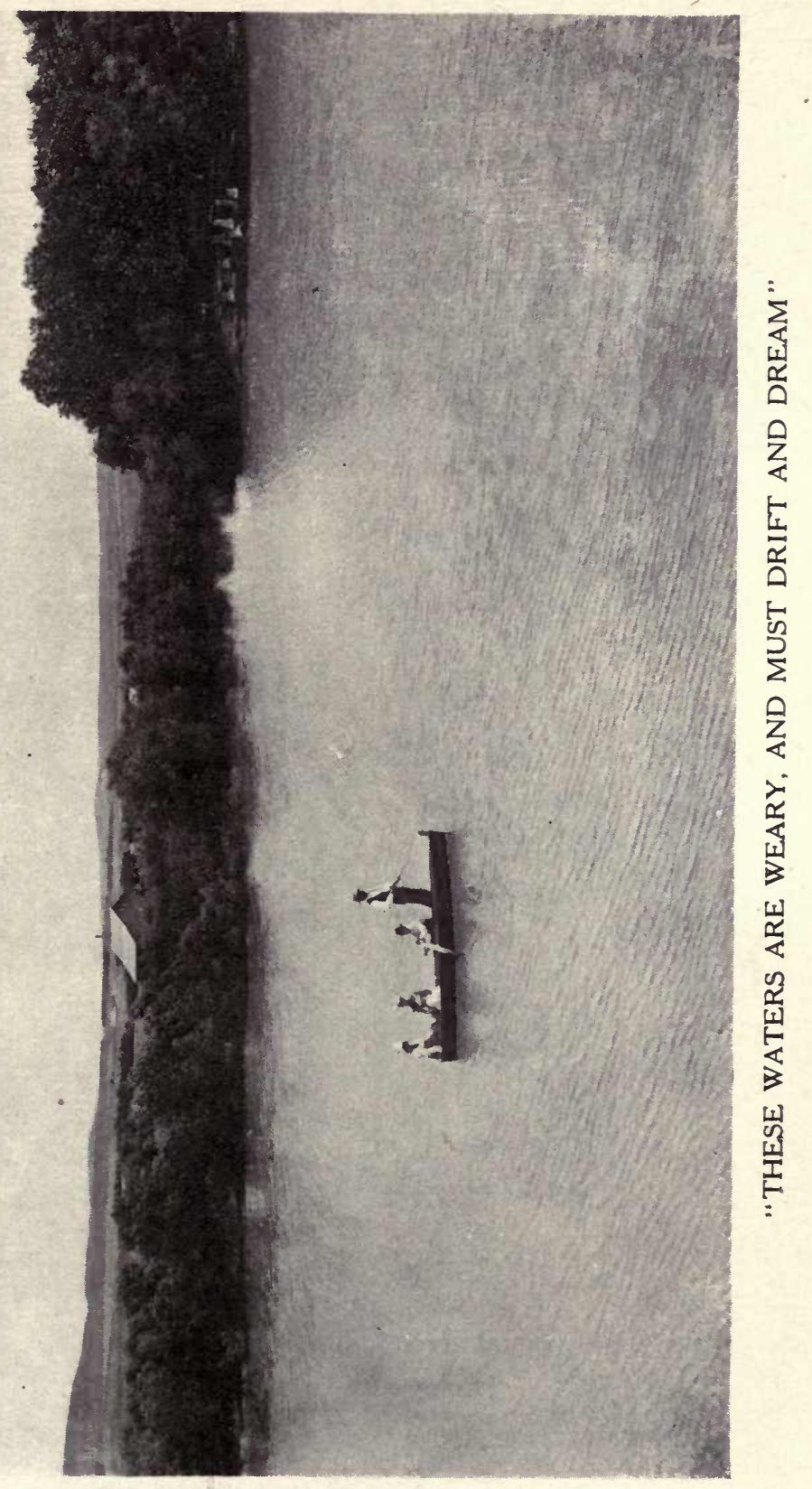





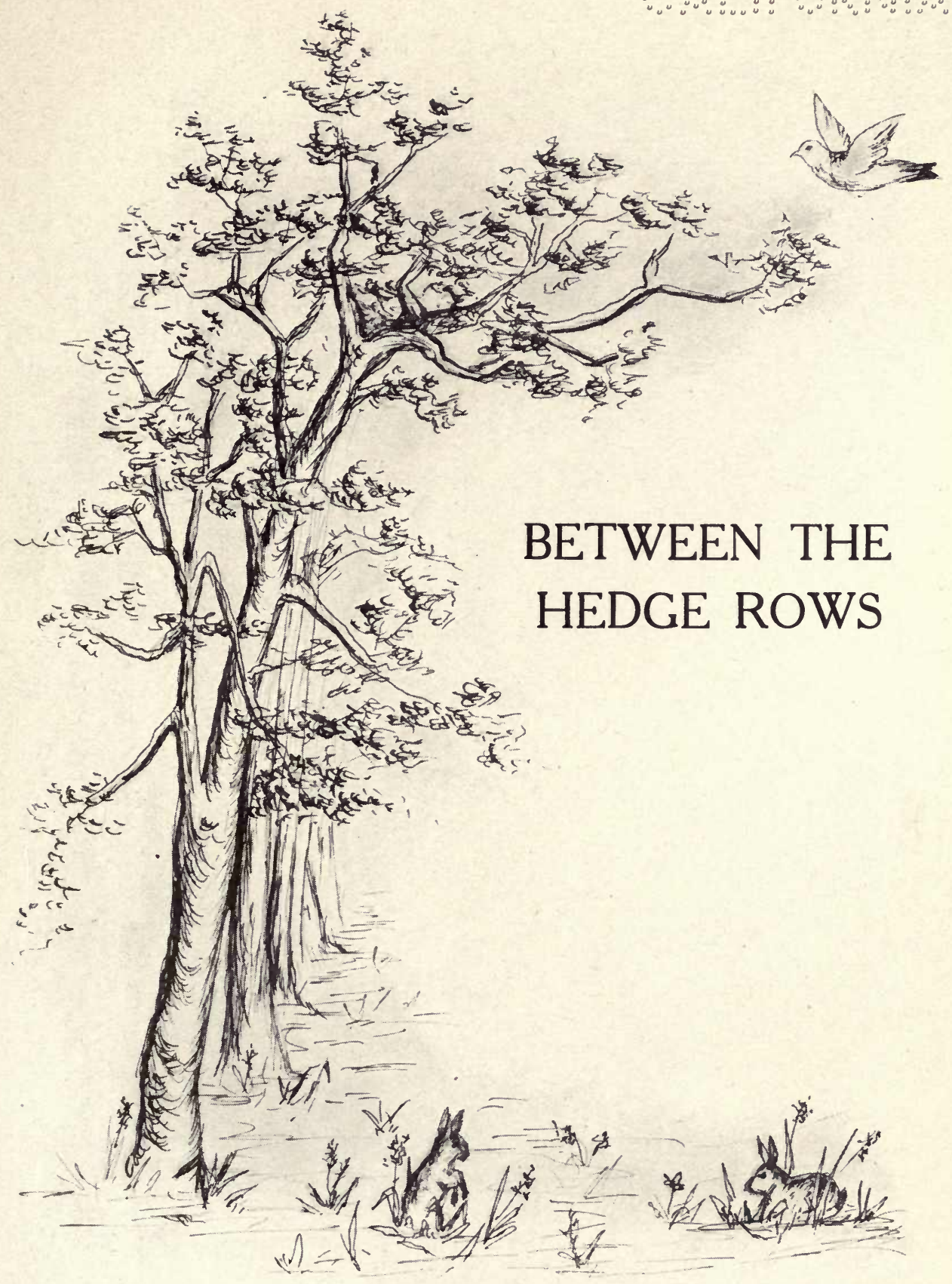


$\because \vdots \vdots \quad \because \because \vdots \vdots \vdots \vdots \vdots$

$\therefore \vdots \vdots \because \because \because \because \because \vdots \vdots \vdots \therefore \cdots$ 


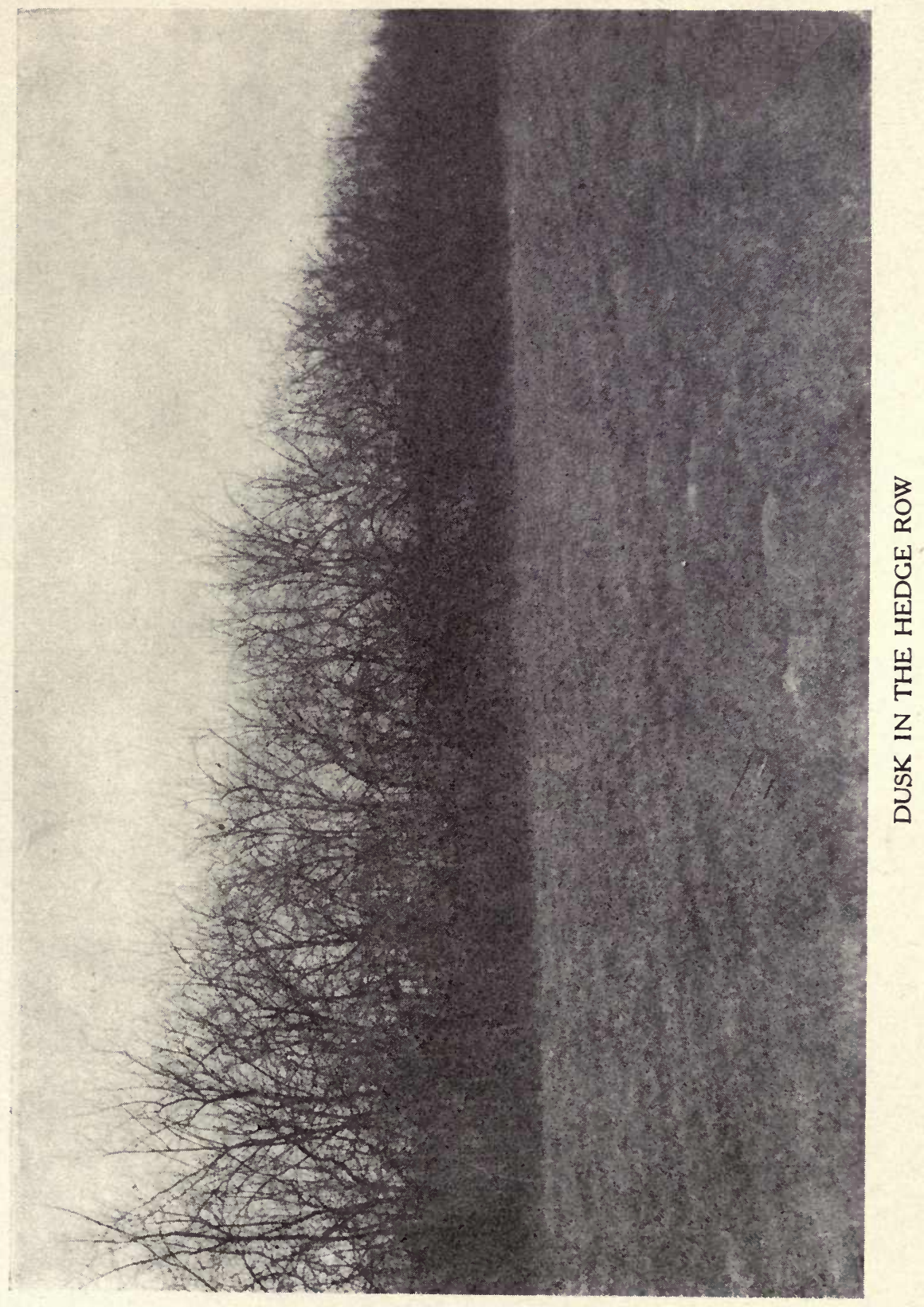


Ho Mit 


\section{DUSK IN THE HEDGE ROW}

IT is one of the charms of a country lane. This osage orange tree is bushy and beautiful. It adorns the edge of the rural road. In it the rabbits have crouched all day awaiting the coming of dusk and dew. It is reminiscent with empty nests. Night is on the world, and the hedge row birds are hushed in sleep.

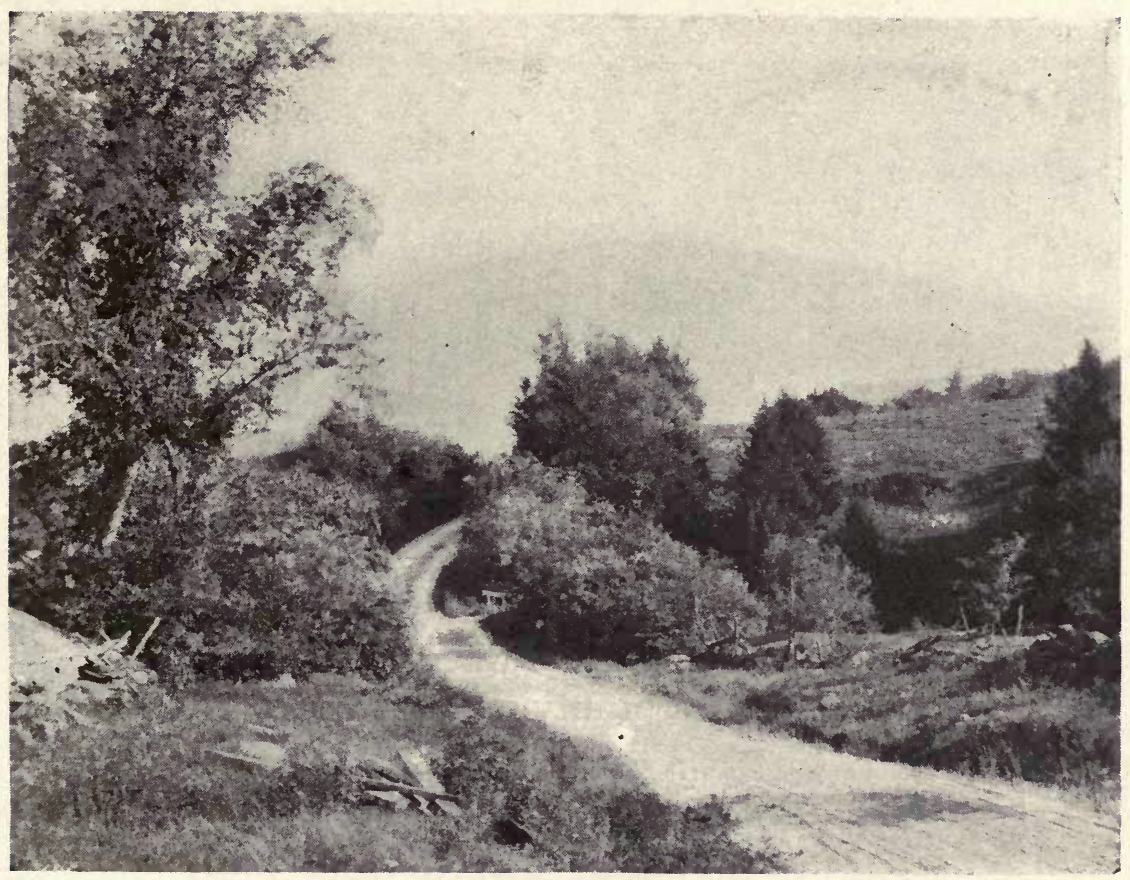

A COUNTRY LANE 


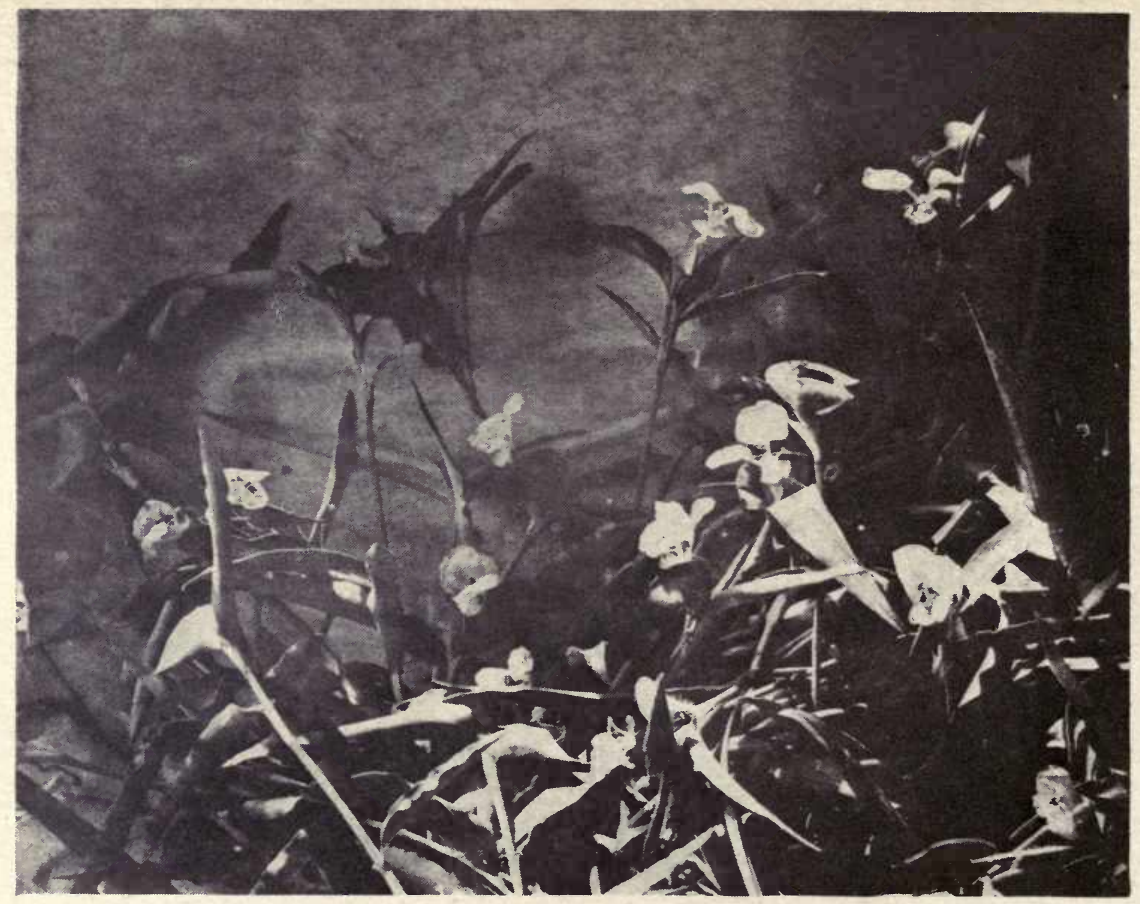

\section{THE DAY FLOWER}

Good-morning, Day Flower, with tresses of blue, Offspring of the sun and the sky are you; Your bright blue blossoms beam on me in bliss, For the love-lips of morning have left you a kiss.

The dawn-breath of June has breathed over you, And the fountains of summer have splashed you with dew;

You glint from the grasses when I pass along, And your music of beauty slips into my song.

The shadows of night have silently crept Away from green beds of the grass where you slept, But the whispers of morning, so fragrant and sweet, Have awakened your beautiful bloom at my feet. 


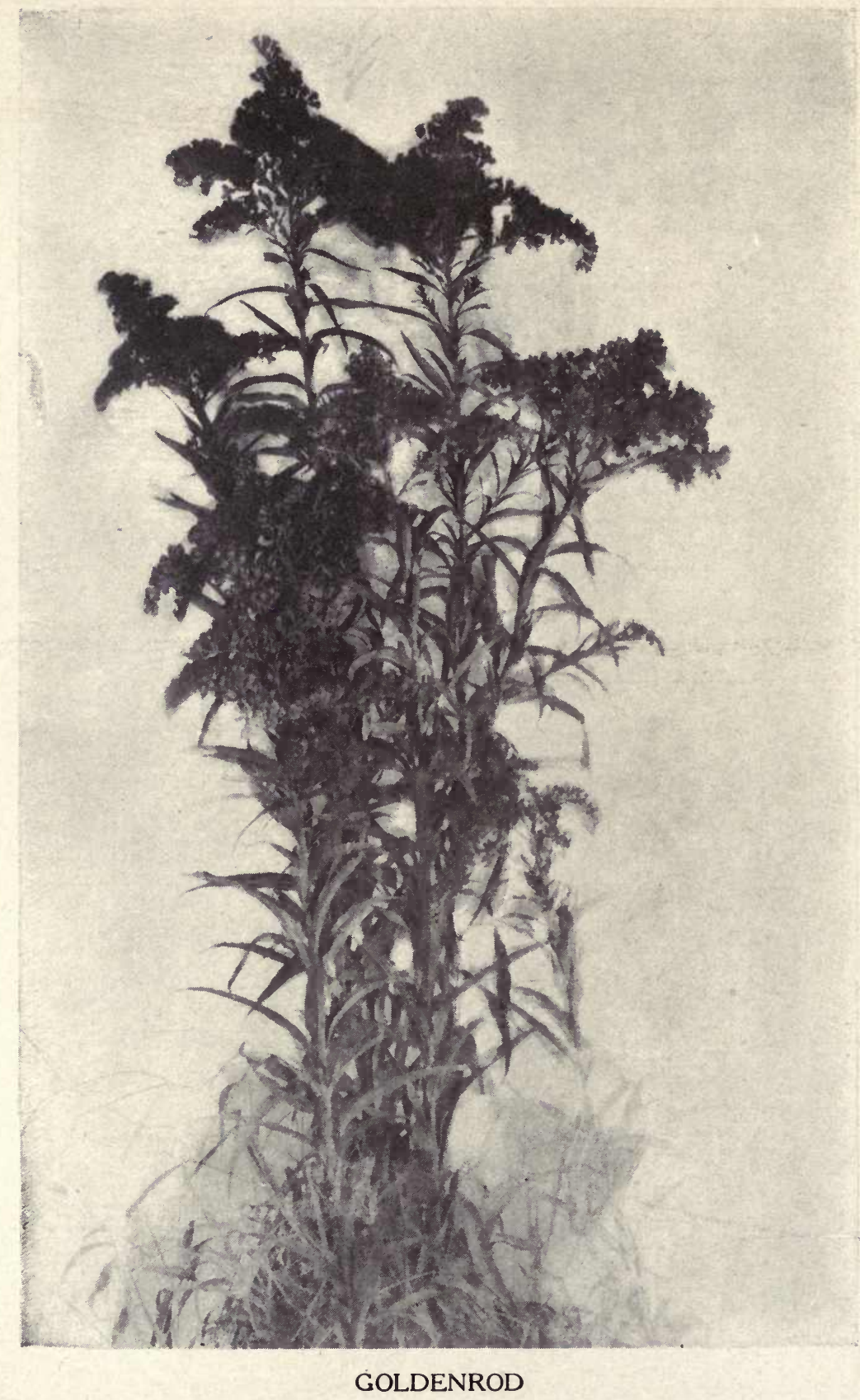




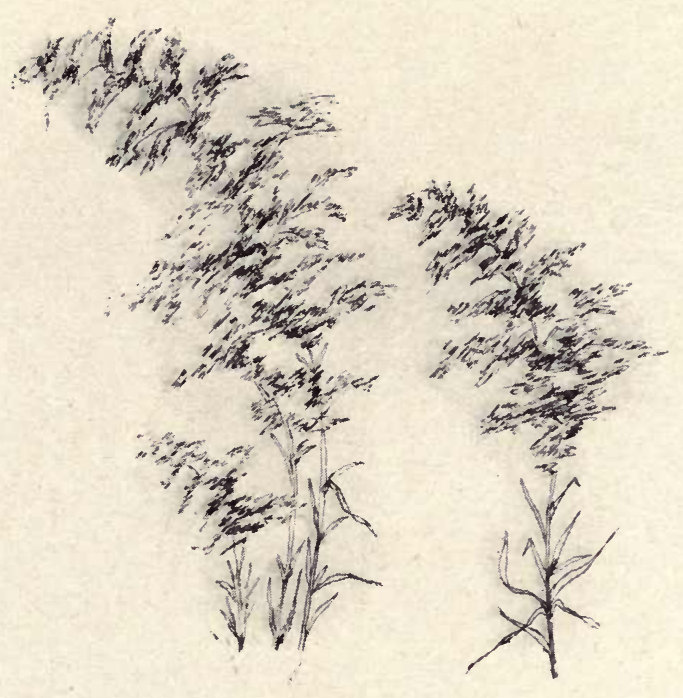

\section{GOLDENROD}

Far out on the prairie the sweet goldenrod Gathers its beauty from sunshine and sod, And scatters its wealth, passing wealth of the mine, In showers of gold for your heart and mine; "Hold wide," says the proverb familiar and old, "Hold wide thy skirts where heavens rain gold." 



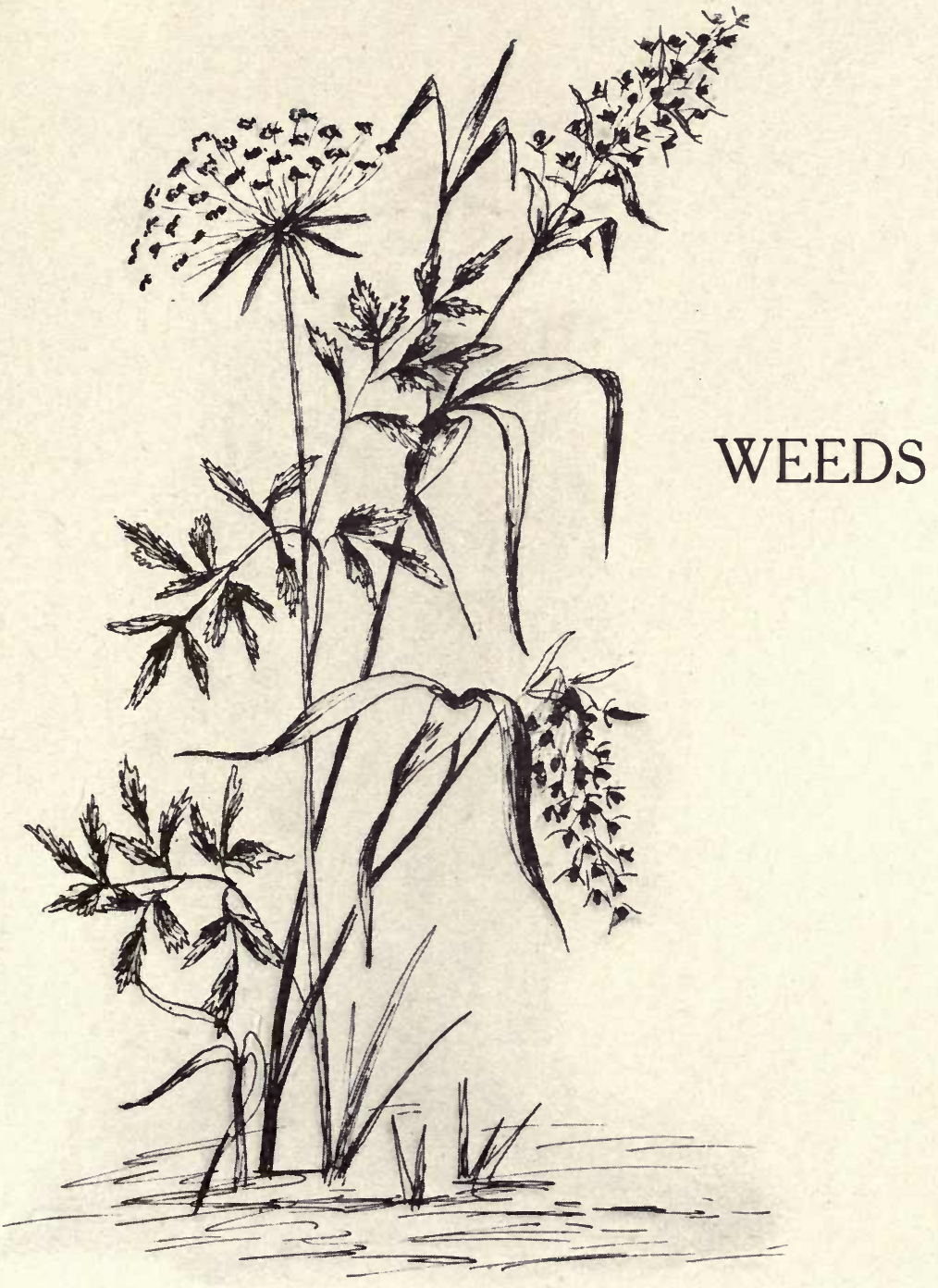





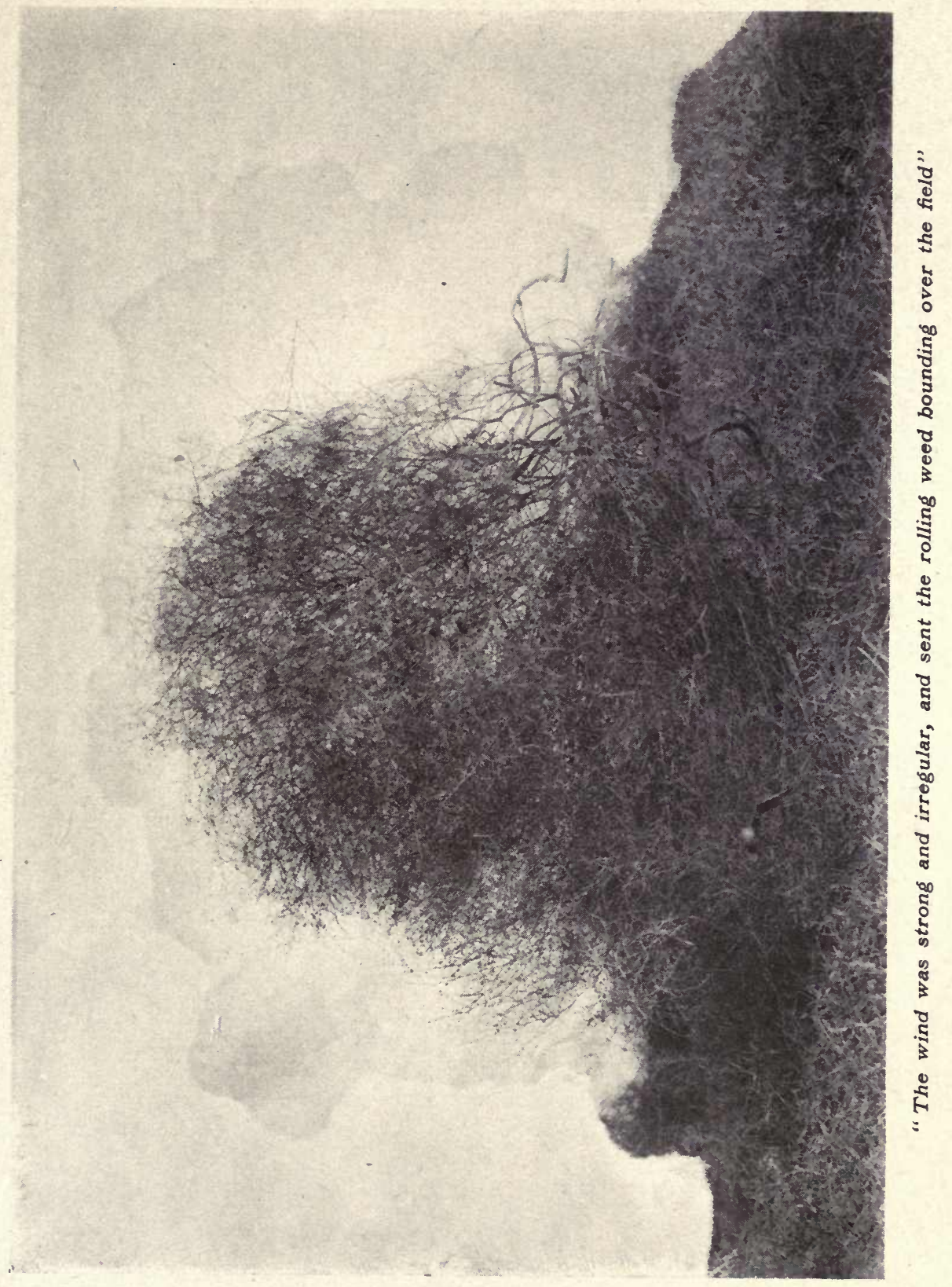


$\because \vdots \quad \because \because \vdots \vdots \vdots \vdots$

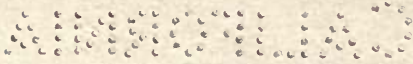




\section{WEEDS}

BEEs find honey in their bloom. That hint of nearby beauty is sufficient to the wise. If "The Man With the Hoe" has eyes, he will look well at weeds before he cuts them away. Weeds are worth while. The Maker of mints and of meadows is also Maker of weeds. Take a look at them. Hogarth's curves are there, for they were nature's before they were his. In them are also Rembrandt's shadow, for the lights of nature made the shadows. Turner's landscape vistas, perspective, and dim distances - all of them are in the wayside weeds. Hugo said, "The beautiful is as useful as the useful." And weeds are, in a limited way, useful. Wheat and corn are so easily grown in the West that, if there were not a few weeds in the way, farmers might grow lazy. But where it is so easy to grow weeds, it is not so easy to grow lazy. Then weeds are the natural shelter of birds, especially on the open prairie. I have seen them scurry to shelter when the driving rain was drenching the plain. Even the loco will shelter a bird when a storm is on. At high noon in the sultry prairie summer I have seen the plover and the lark cooling themselves in the shadows of weeds. The weed-shadow at such a time is a paradise for the toad and the rabbit. When the ministry of shadows is written, it will be the sweet story of sheltering love. Shadows never speak. They serve in silence. At the time of the westering sun they point away from sunset to sunrise. Many a blistered flower-leaf and blade of grass and corn uncurl with new life in the cool balm of the shadow. 


\section{SMART WEED}

The eye it beguiles

With bloomful smiles,

And flowery wiles,

And pink-tinted isles

That spread over miles

Of prairie defiles-

Far-reaches of fragrance and bloom.

When ponds are drained dry

By the sun in the sky,

And common things die,

On thee I rely

To gladden the eye

Of each passerby

With beauty-bewildering bloom.

When winter sweeps down

With bluster and frown

Thou changest thy gown

From the pink to the brown, And losest thy crown,

Though not thy renown-

Weed-wonder so frosted and chilled. 


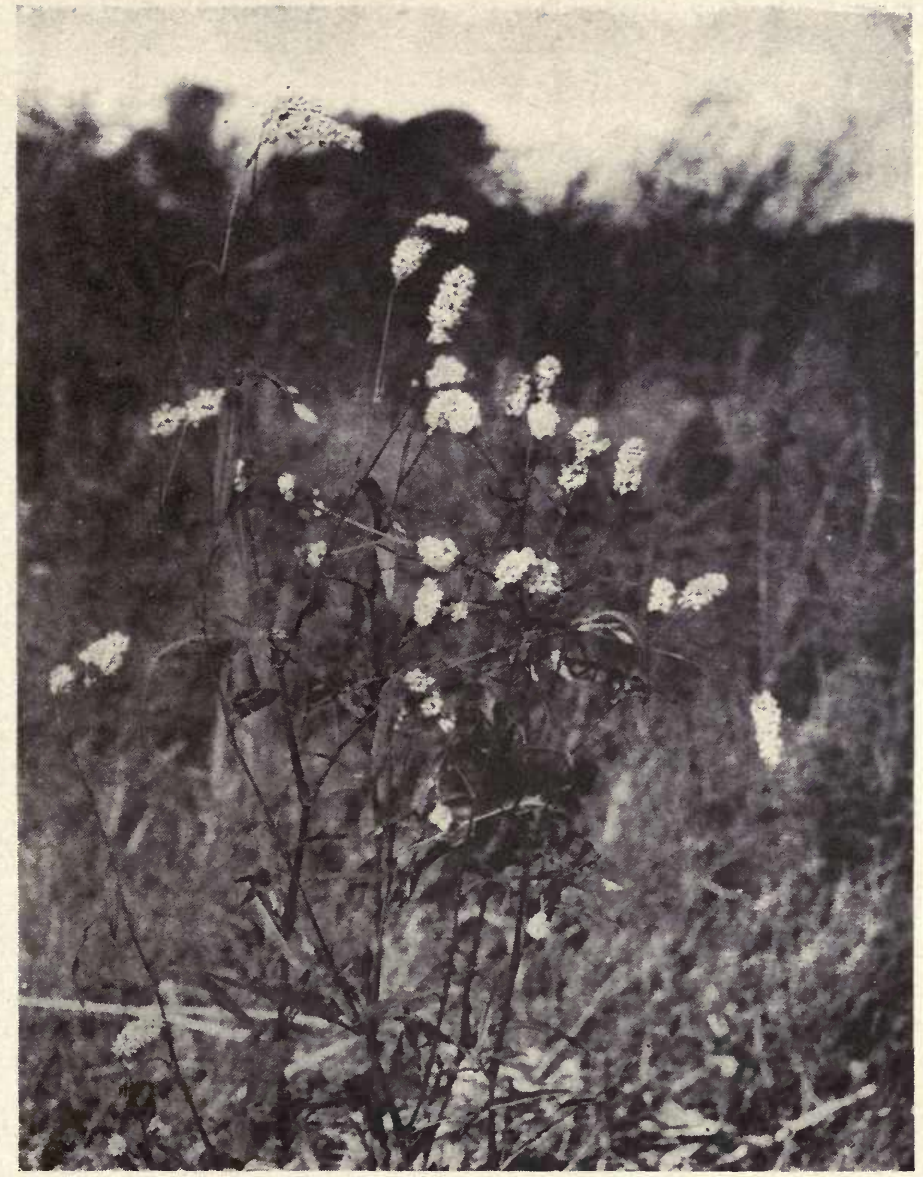

SMART WEED 


\section{Meadow and Mountain}

Turn your eyes again to the weeds. Look at the Lamb's Quarter. It comes in the spring, tender and juicy. You will not see its beauty at first sight, and on the surface. Turn the leaf, then you will see the silvery dust glitter like frost in the sun. Look at it long enough to get its imprint of beauty firmly fixed, then you may take it home for "greens." Or, if you leave it till autumn, it will be worth your while to pay it another visit. It will be from three to six feet tall. Its branches will sprangle like the sycamore's. Its limbs will be as smooth as glass, and very likely its trunk and many of the branches as red as blood. It is defoliated now, but its color and shapeliness are all the more clearly seen. From its central trunk you may carry away a beautiful, dark-red walking-stick.

In the autumn, or even in mid-winter, you are apt to be surprised of a sudden, almost anywhere in the prairie grass, by the sight of the Indian Plume. You will seldom find it in the buffalo grass, but often in the bunch-grass and the bluestem. The plume is a tuft of sheath and seed. It is sepia-colored, or brown, and deepens to almost black in late winter. There is something reminiscent about the Indian Plume. It minds you of summer because its bunches of brown are so much like blossoms. Its tone is as deep as if it held shadows from summer nights.

The Tumbling Weed is as wonderfully made as the cedar tree. This weed in the West is more compact in its structure than it is in the East. It bears a general resemblance to the Russian thistle. The fineness of its fronds and delicate leaves make it a thing of beauty. It is conspicuously green, and so remains till killing frost comes in the fall. It is a beautiful green sphere of vegetation. It is a beautiful 


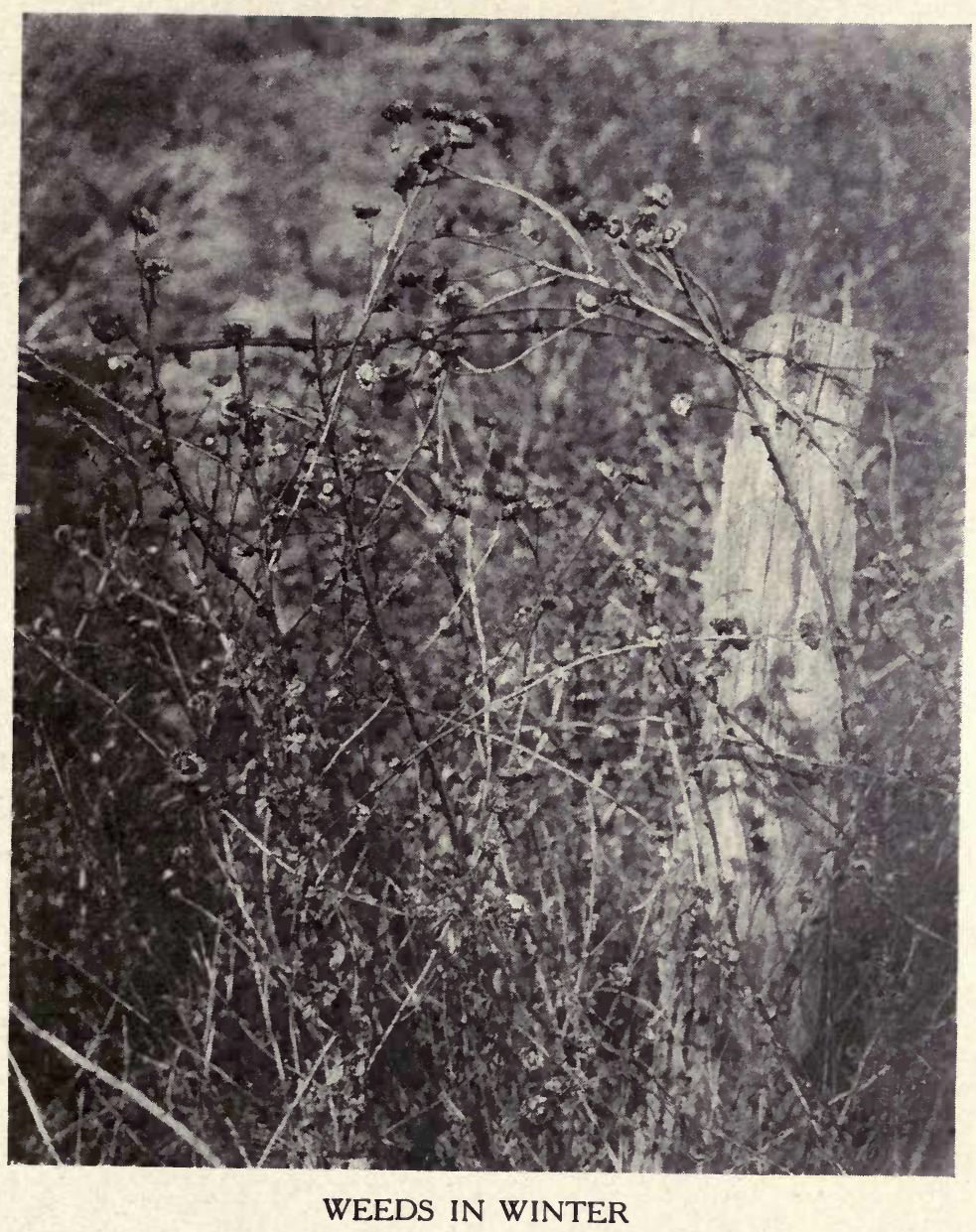




\section{Meadow and Mountain}

sight to see this ball of green roll and bound across the level prairies, now and then leaping a fence or rolling clean over a cattle shed. But its roots seldom let go of the soil, even in the strongest wind, till the tiny seeds are ripe and black. The weed is content to stay in its place till it can scatter its life by going.

Winds and weeds work together,

Day and night in every weather.

One day in autumn I saw three country lads strolling across a field of wheat just greening the ground. The wind was strong and irregular, and sent the rolling weed bounding over the field. As a large one came near them, it was a banter to the boys. They were simultaneously possessed with a bright idea. They seized a shuck which had strayed in the wind from a nearby field of corn, and, lighting it, tied the torch to the weed. Soon the whole was a rolling flame which leaped wildly in the wind toward the farmhouse, the barn, sheds, and stacks that stood at the edge of the green wheat field. The startled boys ran with the wind after the flaming weed, catching and crushing it just in time to prevent disaster and loss of property. As fire-brands, these weeds would have been more than a match for the flame-tailed foxes that Samson set among the Philistine fields of standing corn. But the sight of a rolling flame over a field of green was beautiful to see.

In certain aspects of it, the Pig Weed is a thing of beauty. At a distance it looks like a diminutive lombardy poplar tree. Its leaves are dark-green in summer and early fall, but after frost they are seared and brown. When draped with wintermist frozen into frost they look more lovely than cathedral 


\section{Weeds}

spires. Under icy loads of sleet I have seen them curve in crystal arches to the ground. I have seen them sparkle in the winter sun like plants full-hung with diamond blooms. It is worth your while to pause at the roadside and take a look at the Pig Weed.

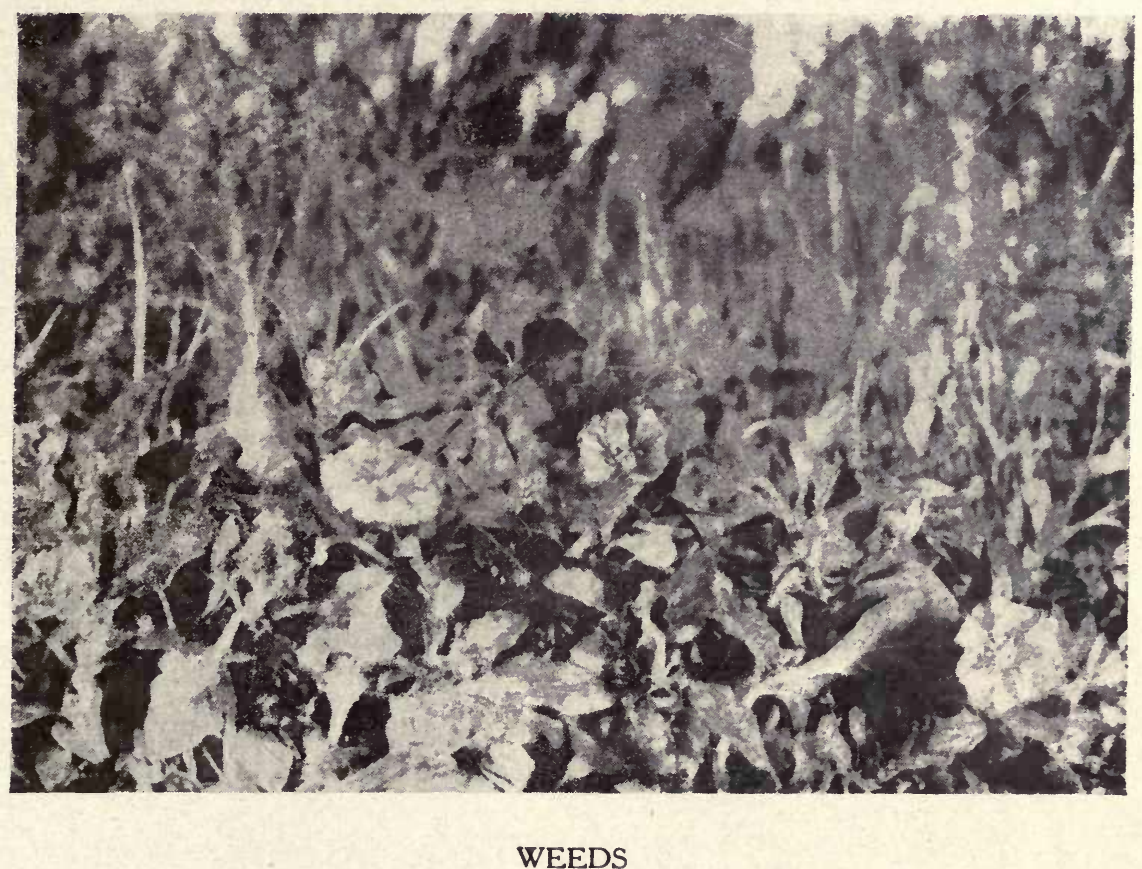

"Bees find honey in their bloom" 



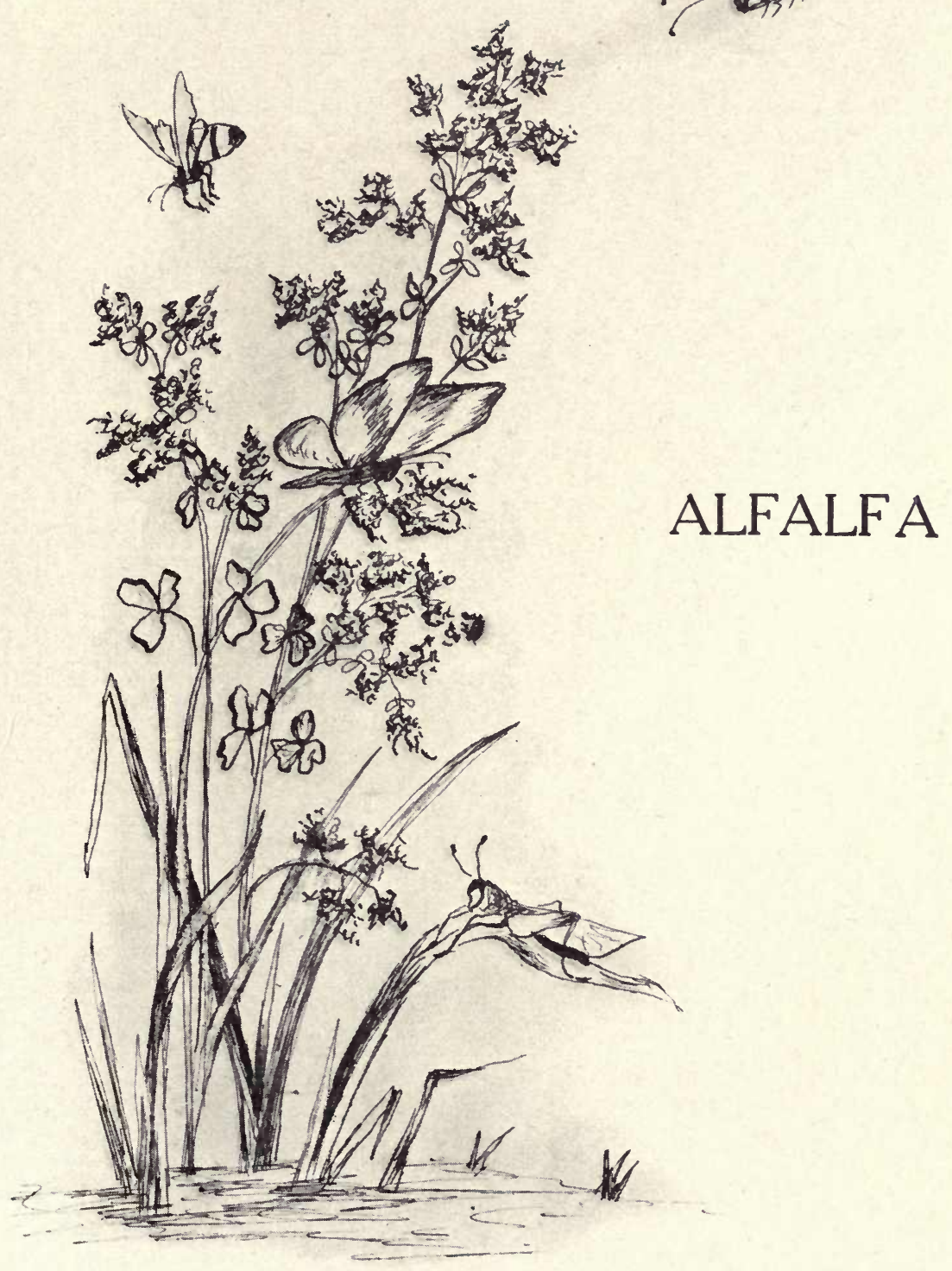





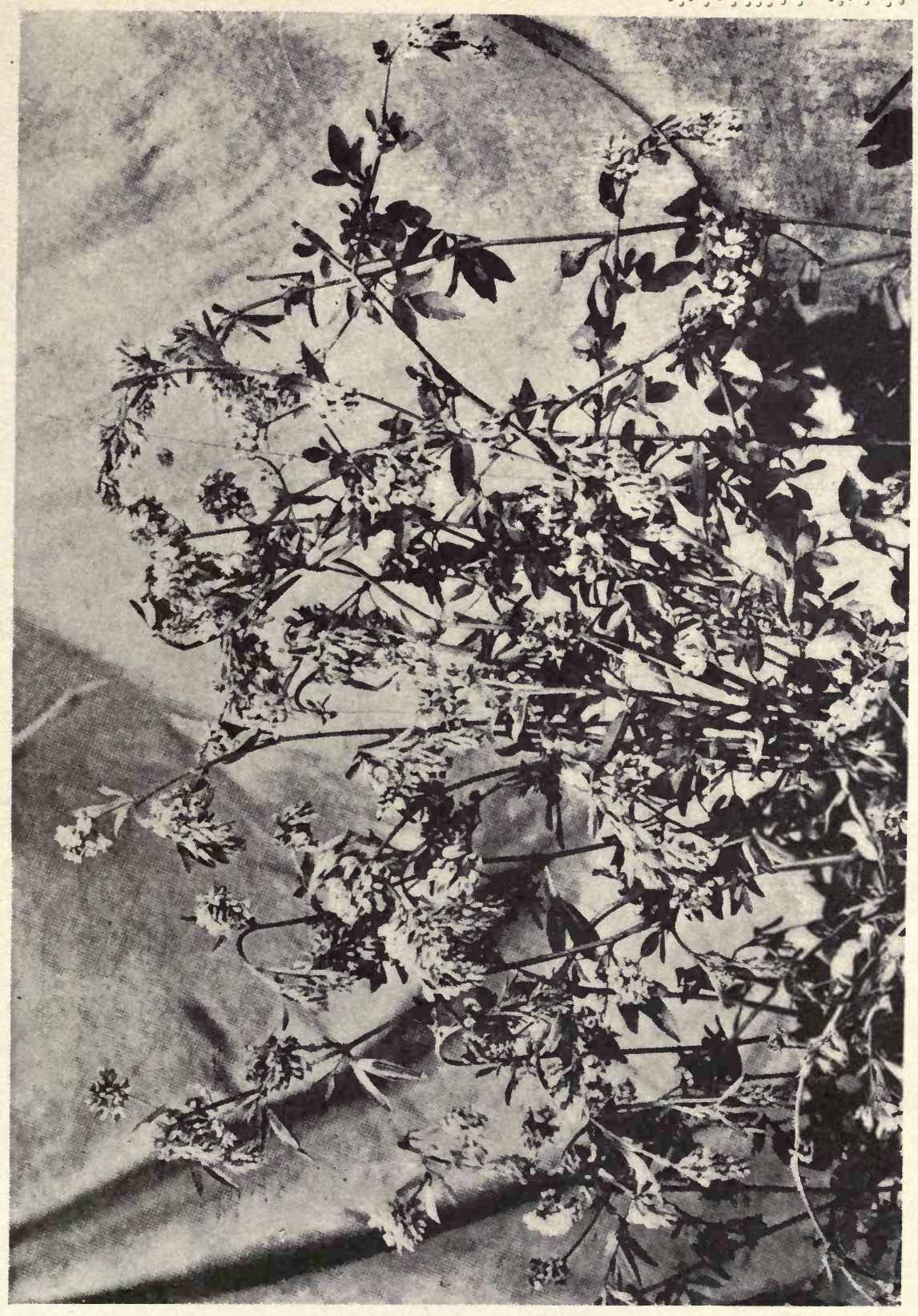


$\because \vdots \vdots \quad \because \vdots \vdots \vdots \vdots \vdots \vdots$

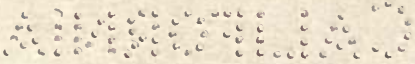




\section{ALFALFA}

Ten thousand wells were in a field, And not a well was dry, Nor did they any water yield To thirsty passersby;

Of purple blooms the walls were built, With masonry complete,

When summer skies the sunshine spilt, And filled them full of sweet.

Every well was swung in air, And each was blossom-bound, Unnumbered pilgrims tarried there On that fair camping-ground;

O'er the field flew butterflies

Like floating flakes of snow Wafted down from wintry skies So soft and still and slow.

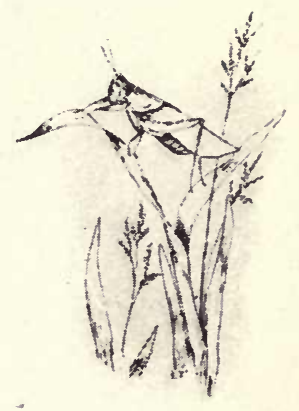

In that alfalfa field I heard

The serenade of bees, As when the breezes blossoms stirred,

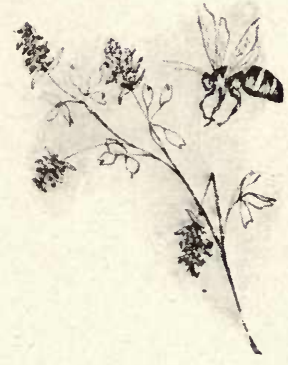

Like trembling organ keys;

I read the mystic meadow rune, Ensphered with rare perfume, And heard the lark's love-lute of June Trill o'er alfalfa bloom. 

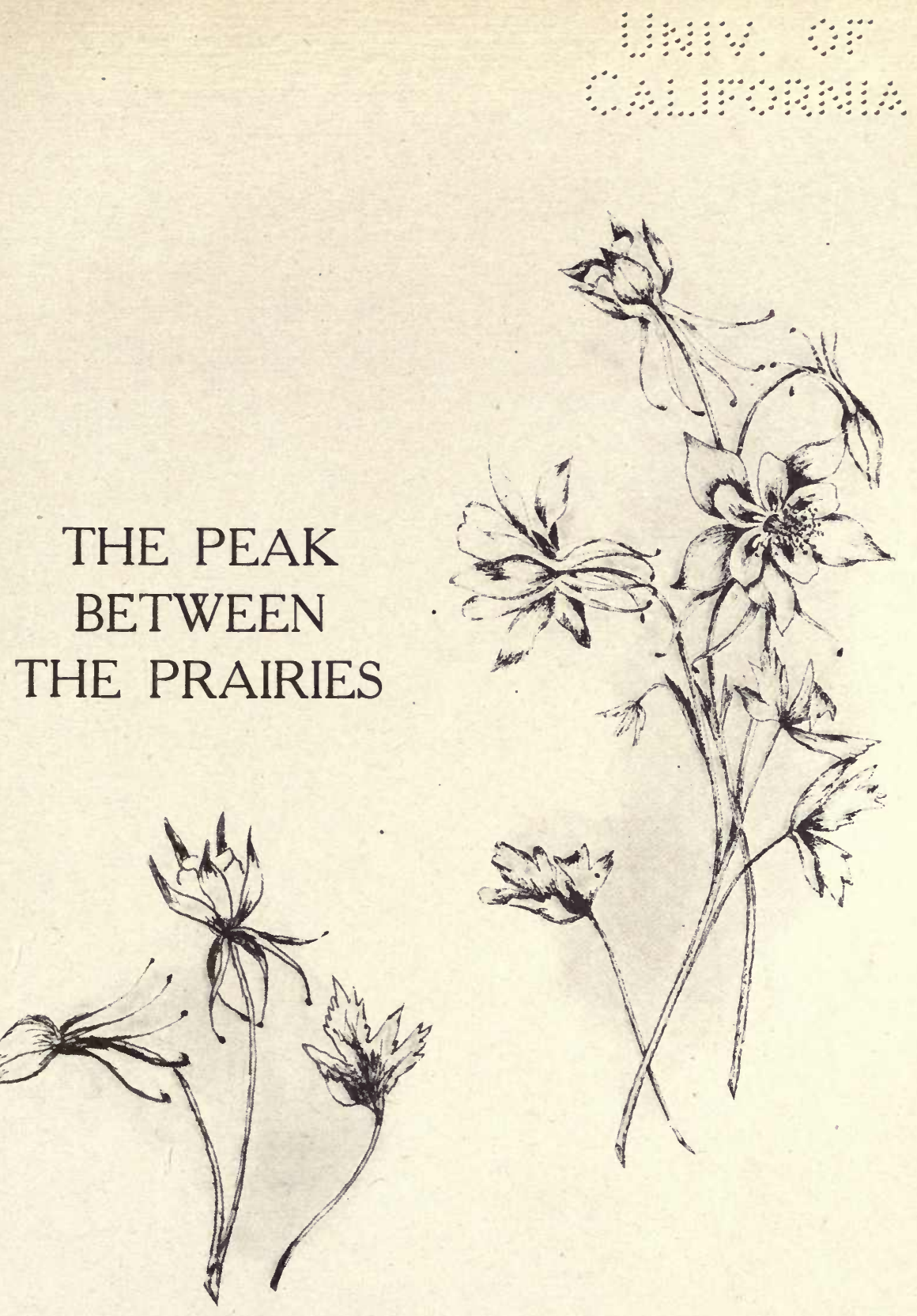


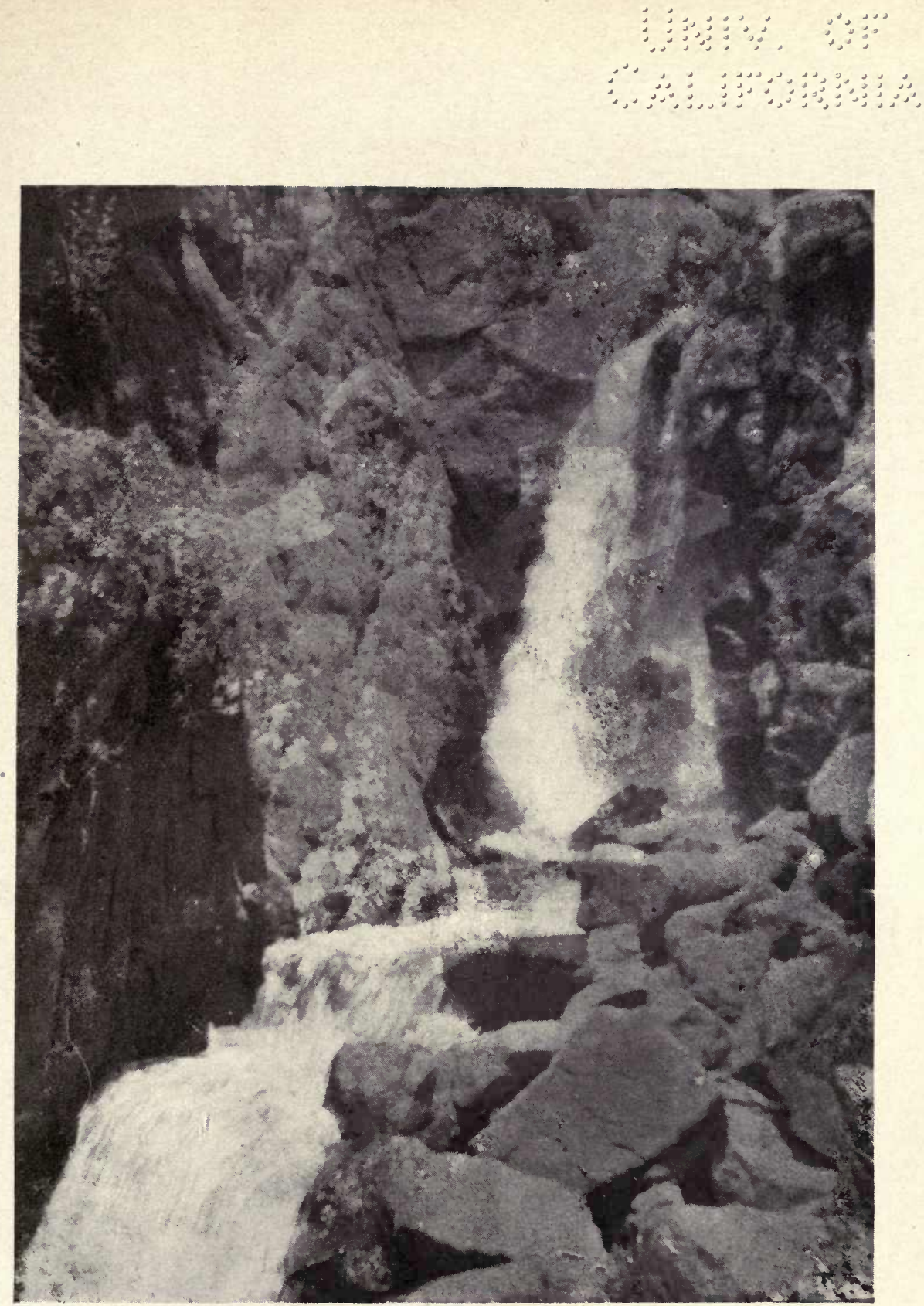

“LAUGHING RIVERS SING THEIR WAY DOWN THE STEEPS” 
and

antwound 


\section{THE PEAK \\ BETWEEN THE PRAIRIES}

IT is a huge hill with a thousand secrets in its heart. There are cities at its base, forests of aspen, cedar, and pine on its flinty sides, and a million tons of broken granite on its crest. The shovels of centuries have scooped a pile of sand, gravel, and big bowlders into a heap that stretches away to the skyward for fourteen thousand feet. The flinty peak lifts itself to dizzy heights far above the timber line. The sharp blades of wind and weather, together with the keen chisels of frost and snow, have made deep scars in the mountain's side. The snows of ages have drifted their stainless beauty over the rough shoulders of this lonely sentinel. Scores of laughing rivers sing their way down the steeps in summer time to the parched and panting prairies. A hundred placid lakes sleep in the dimples between the engirdling hills. Blue bells, snap-dragons, goldenrod, asters, buttercups, forget-menots, and mosses of many makes and hues spread their spendthrift beauty in a thousand nooks and corners. Some species of cactus bloom at the snowdrift's edge. It is not so much the cold that keeps the snow as the lightness and the dryness of the air. The chipmunk is happy here in this lofty loneliness. Now and then a vulture or a straggling crow wafts his weary wing sheer over the mountain. Here at high noon, when the sky is clear, sunbeams and shadows lace and interlace each other like the swift-flung threads of a weaver's loom. The weird moaning of the mountair winds, 


\section{Meadow and Mountain}

the ominous hush between the gusts, herald the gathering storm. The thunder-throated clouds roll their wild anthem across the crest of this serene sentinel between the plains. Every unsheltered boulder is dismantled of its débris and dust. For a little space havoc has reigned among the hills. But the clouds are falling apart like a garment burnt to ashes by the flame. They scurry down the long slopes like black beasts to their lair. Silence and sunshine take the place of the din and darkness, and I, amid bewildering beauty, am glad with unwonted joy that I, for once, have wooed and won this high hazard of the mountains and the hills.

It was worth a high climb toward the moon to witness that storm on the mountain. It was nature's apocalypse. It was a kind of Angelo's "Last Judgment" frescoed on the skies. It was like a mighty military masquerade of the grim warriors of the world come to do battle for the ages. But when the clouds were drifting from the mountains, and the radiant mantle of morning was flaming up the stairways of the hills, it was a sight to hold the heart with eternal memories. This pageantry of storms and morning on the mountain was worth a trip across the world to see. 


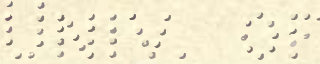

$$
\begin{aligned}
& \text { 。 }
\end{aligned}
$$

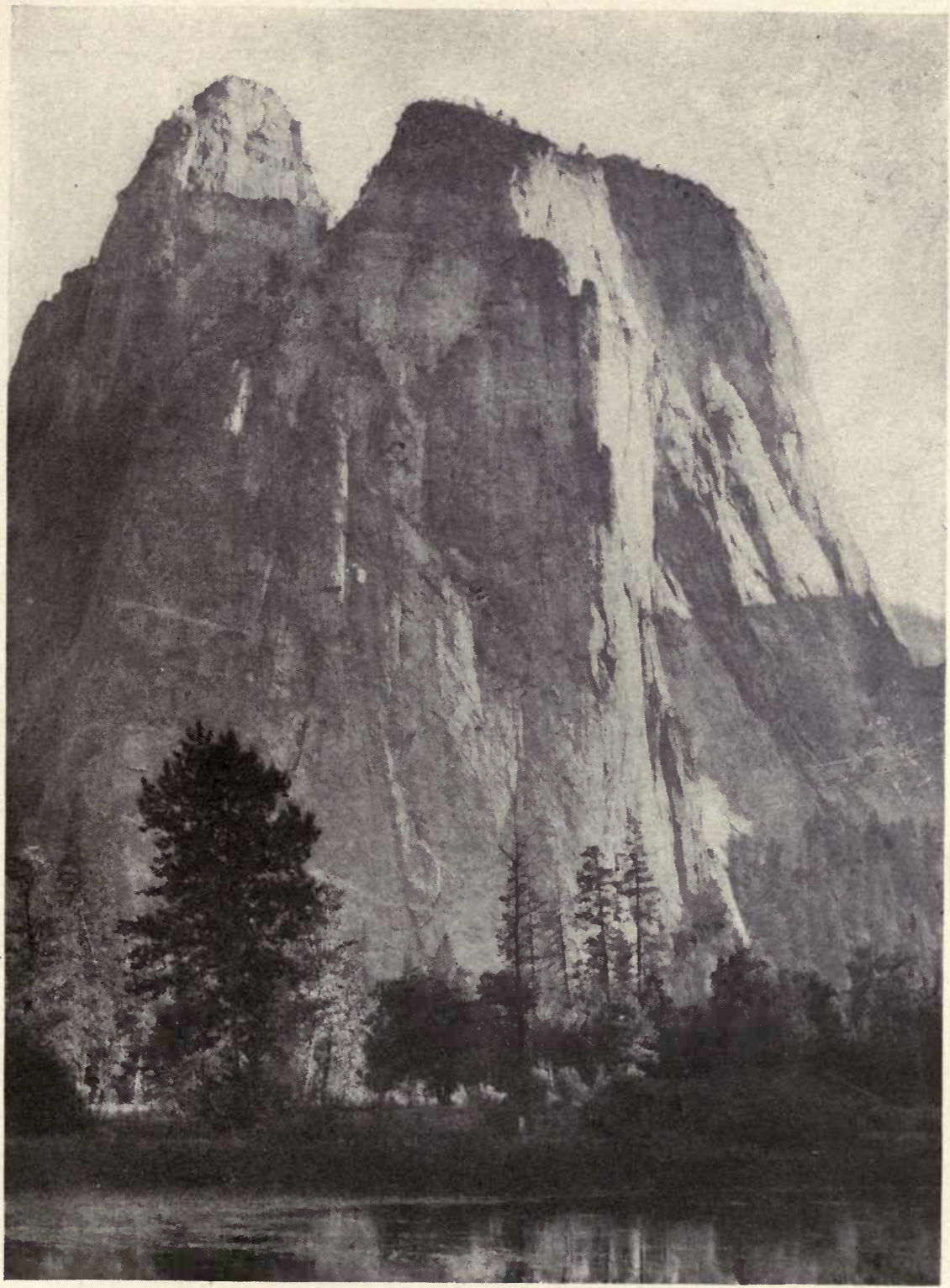

HIGH DOMINIONS 
and 


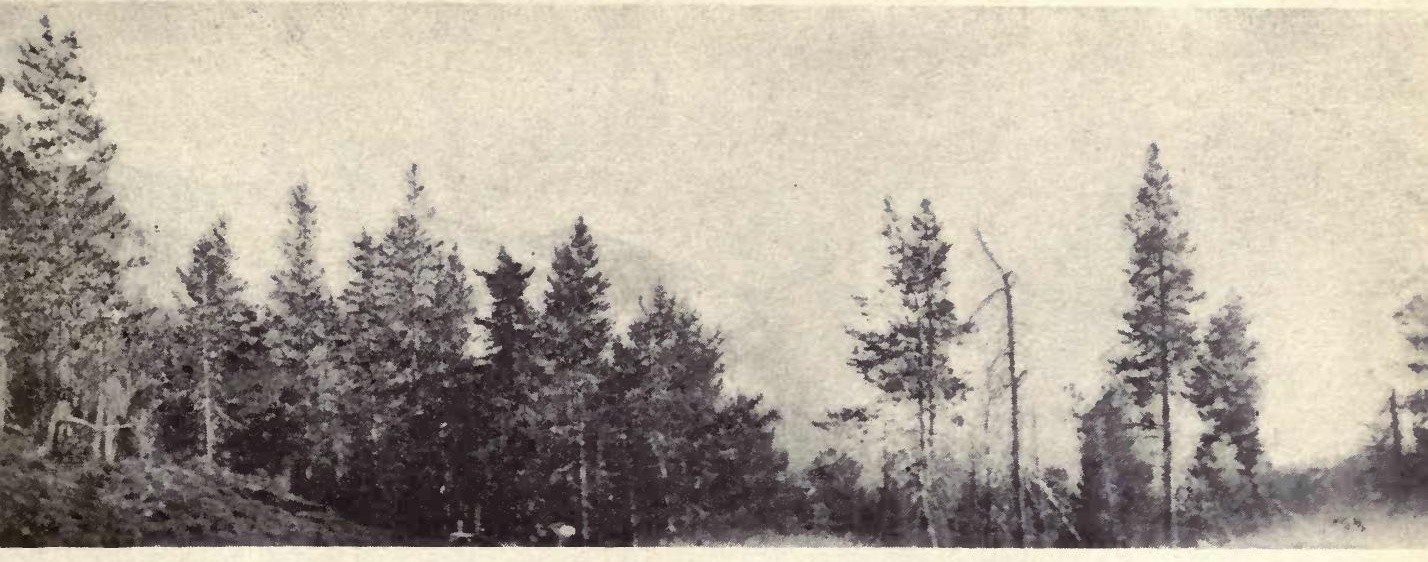

\section{MORNING ON THE MOUNTAIN}

Before the virgin morn

Had laid her scented lips

In kisses on the valley corn,

Or hills wore fire-tips,

I climbed the night-veiled height

Where sullen shadows sleep,

Where storm joins storm in Titan fight

And whirlwinds wildly sweep;

I saw the purple dawn

Creep up the mountain's side,

And as young Day put sun-robes on,

I saw Night's blackness glide

Over the riven stones

In quest of ghostly glooms,

Among Death's bare and bleaching bones,

In far-off valley tombs;

I saw the placid lakes

That slumber on the slopes,

While every other creature wakes,

Abloom with morning hopes; 


\section{Meadow and Mountain}

Commingling with the sough

Of magic mountain breeze, And stealing soft o'er flinty bluff,

Where sighed the cedar trees,

The matins of the morn

Escaped the waking bird

While baying hound and blaring horn

In trance of joy I heard.

Then suddenly there fell

Upon the mountain's crest

A cloud that stretched to utmost dell, And spread from east to west;

When heaven's artillery broke

In lightning, wind, and rain,

Till every mountain gorge did choke

With floods that sought the plain;

Then reigned the hush of death, Save where the currents flowed,

Swollen and swift, to reach the heath Where thirsty cattle lowed.

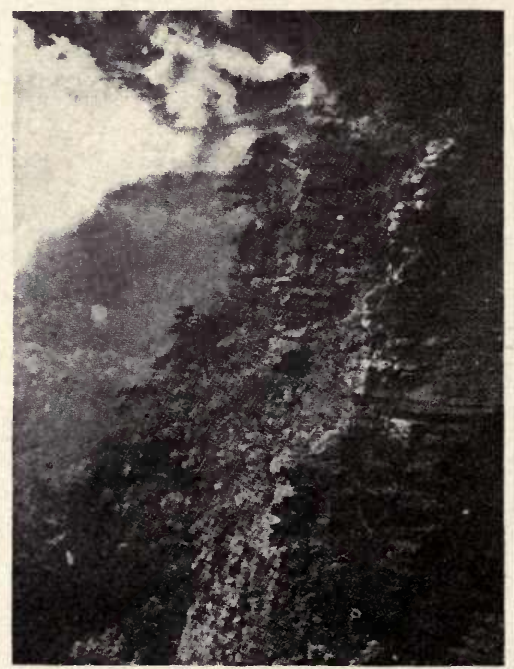



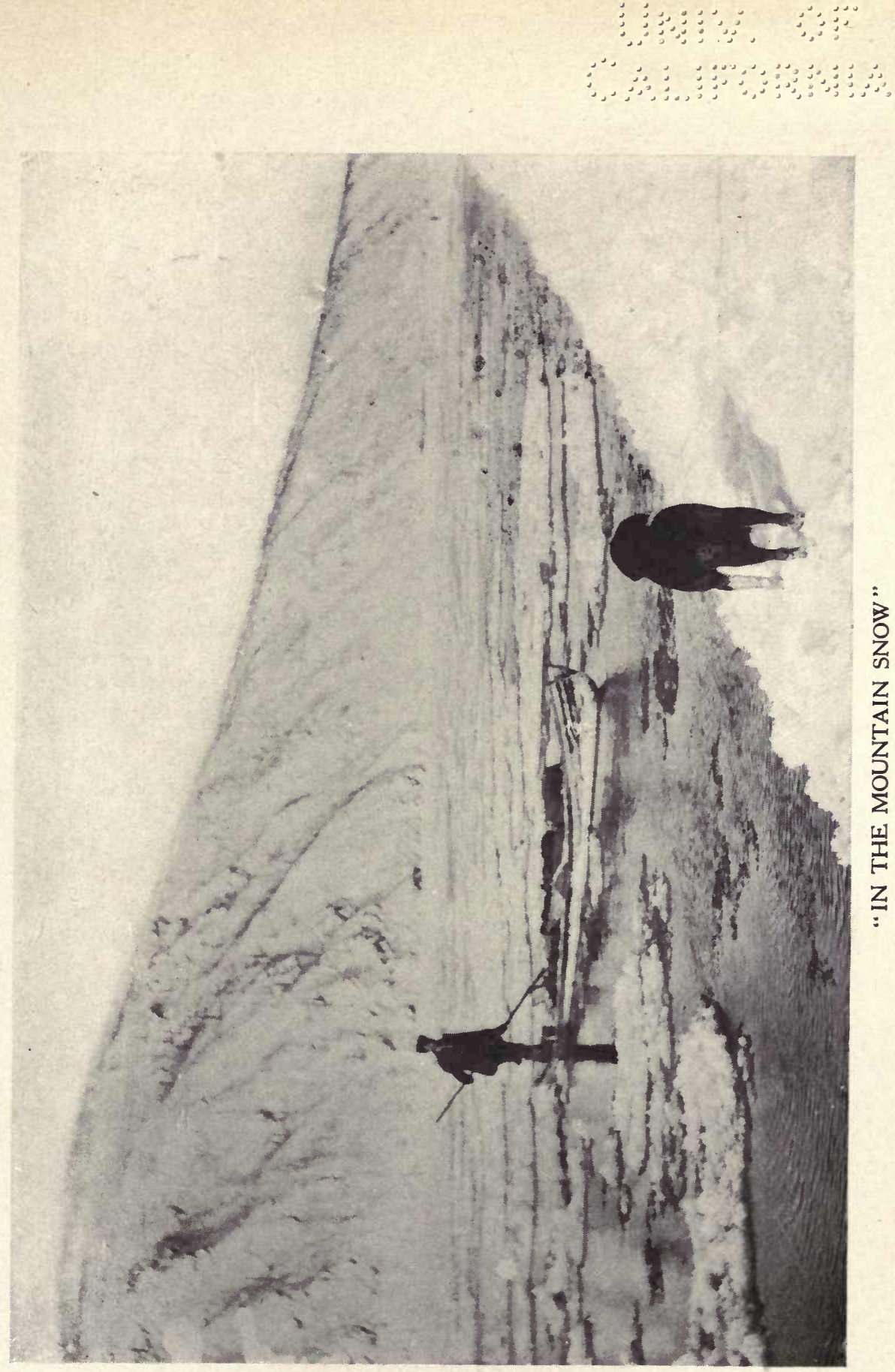

$\therefore \quad 2000$ 


\section{The Peak Between the Prairies}

Impassioned cataracts dashed, Frenzied, from hill to dell, While giant cedars reeled and crashed

Where Vulcan's thunder fell;

The war of waters raged

Among the trembling trees,

And huge, gray boulders, disengaged,

Were toppled o'er with ease

And tumbled down the steep

To darksome deeps below

Where, through long centuries they sleep,

Nor wake to weal or woe.

Now glow the high dominions

With sheen of morning light,

As newly slipped from angel's pinions,

Outreached in lofty flight;

Softly the white waves spread

In seas of solar glow,

Gilding the hoary mountain's head

For ages crowned with snow;

Enchanting vision, stay,

Nor fade when I am old,

When steps are slow, and locks are gray,

And sunset gates unfold;

Follow me past the night

Into the tearless day;

Wave thy angel-wings of white

Till shadows flee away. 


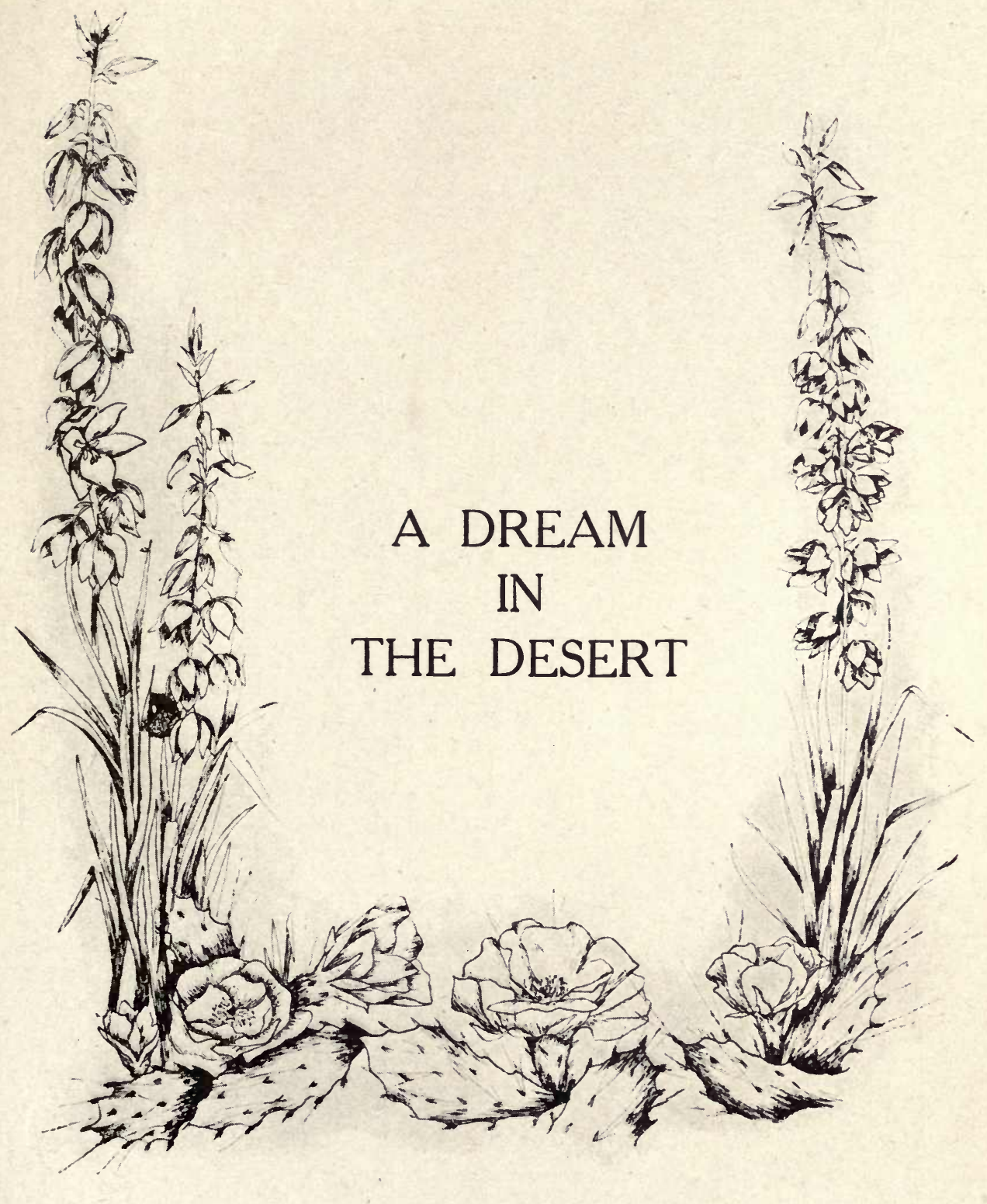




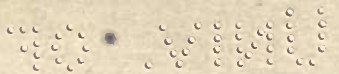

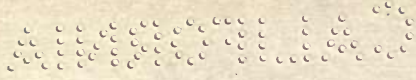




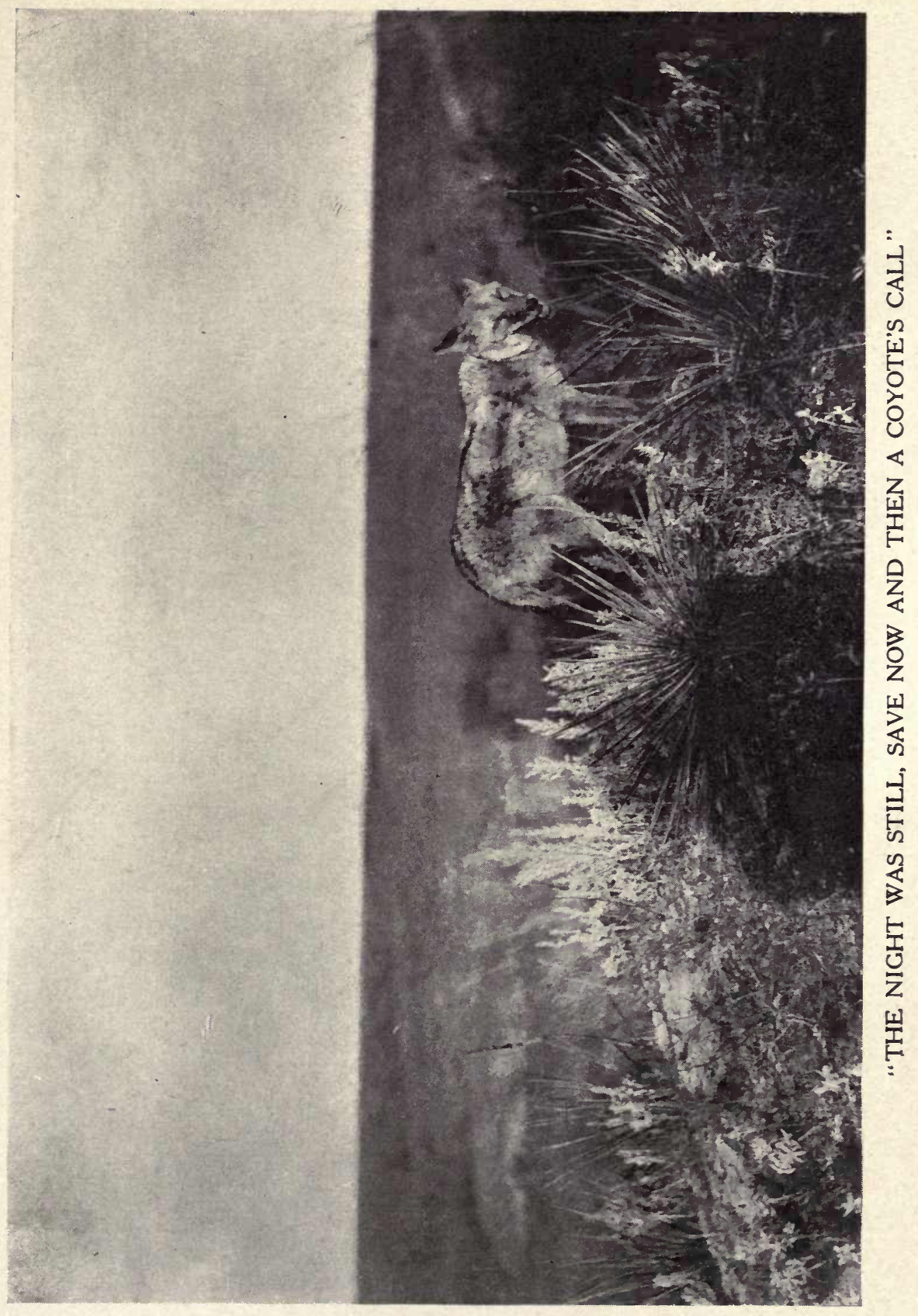


$\because \vdots \because \cdots \cdots$

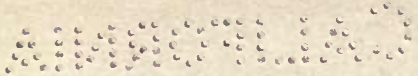




\section{A DREAM IN THE DESERT}

[It is said that in the old Truckee mining district in Nevada there is a mountain from which issues, each evening at dusk, a most exquisite and delicate music. The mountain was discovered by a party of prospectors in 1864. It is situated on the Truckee River, near Pyramid Lake. It is further claimed that the Piute Indians were familiar with this musical wonder, and called it "The Singing Mountain." The face of the mountain is covered with thin flakes of crystalline rocks, many of which stand on edge. The music is produced by drifts of débris which slide down the mountain side between the rocks, which stand on edge. Only a slight breath of wind is sufficient to start an avalanche of gravel and débris. The music is oftenest heard after sundown because of the stillness which usually prevails at that time.]

THE sand had glistened all day in the hot sun like sparks of fire. The wind was as hot as if blown from ovens. A tawny traveler had set out from his tepee-home in search of civilization. Bits of tradition from his youth-time had drifted over the fields of his fancy. In these flitting fancies were hints of human homes that far surpassed the rude haunts of the red man. Wewoka had often wondered where and what these happy homes could be. An ancient chief had once brought with him, on his return from a long journey, snatches of strange and wondrous tales.

After traveling from early dawn, Wewoka was weary. His feet were blistered by the hot sands. His lips were parched with thirst. He was hungry and lonely. Dusk stole over the desert like a slowly-creeping shadow. And as the shadows fell over the world, slumber fell over Wewoka's weary eyes. The night was still, save now and then a coy293 


\section{Meadow and Mountain}

ote's call. It was on this night that Wewoka had the dream in the desert. He was joined in his journey by a Piute Indian. As they walked together day by day the Piute told of a wondrous mountain that sang strange and sweet songs at nightfall.

As evening wore on into the night there was a delicious hint of humidity in the air. The bare suggestion of dampness is a relief in the dewless desert. As dusk and dreams gradually crept over the weary Wewoka, an exquisite odor arose from the sage-brush couch. The cool night winds coax the aroma from this silver-leafed shrub of the sands. And night or day, when the traveler's feet press the wild sage's pungent pods, it gives forth the sweetest scent.

As the Piute discoursed of "The Musical Mountain," Wewoka was hushed with a wordless wonder. He wist not that the Piute pilgrim, who had joined him on the desert sands, and the mountain's music were woven of slumbrous shadows by the spirit of dreams.

The Piute told Wewoka how the chieftains of his tribes in the olden times had camped at the base of the Musical Mountain. He told him how the winds of the evenfall blew melody from the mountain's crystal brow. Then the Piute pilgrim sang the "Musical Mountain's" long-forgotten strains:

Encamped at the base of a musical mountain,

Melody gushed as if from a fountain,

Till campers forgot their quest for gold,

As the dulcet notes in the twilight rolled;

Some mystical fingers had smitten the strings

Of a magical harp hid under night's wings,

Or the elves of the breezes were crooning love's lay

To the old Truckee Mountains so wrinkled and gray;

The ravishing strains from the time-scarred brow

Of the symphonous mount, winds waft to me now- 


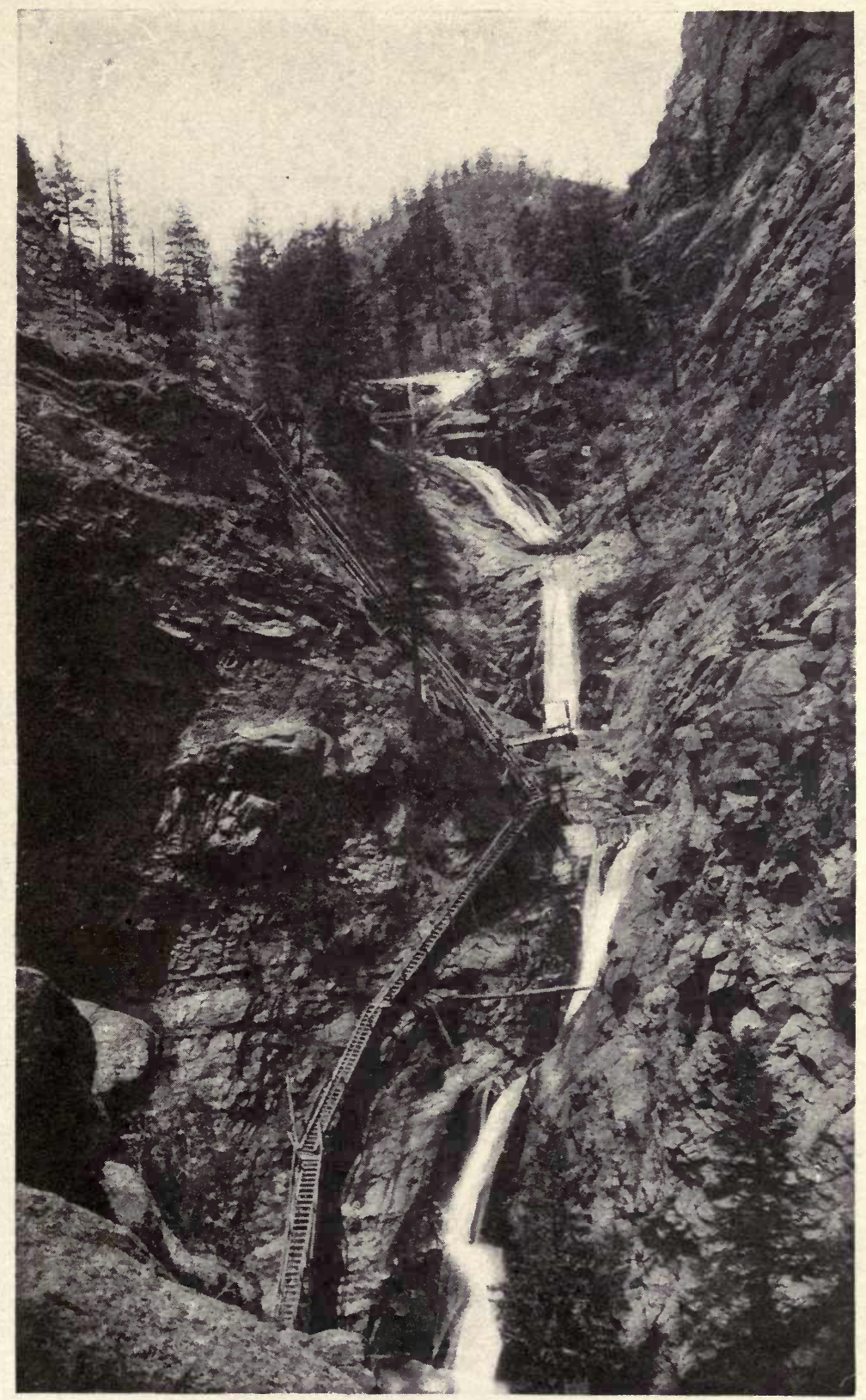

"CASCADES LEAPING IN MOUNTAIN GLOOM" 



\section{A Dream in the Desert}

Like Elysian rivers the musical flow

Glides over rock-crystals as white as the snow;

The clear sound-ripples in soft singing spray,

Steal over my tent at the death of the day,

While melody's magic entrances my ear,

And this is the rapturous song that I hear.

"But tell me, good friend," interrupted Wewoka, "how can a mountain sing? And how can there be music in the voice of the wind? Mountains are mostly rocks; melody comes from living things that sing. I have heard the lark and the plover, and now and then on the wide spaces of the windblown prairies I have heard the curlew's call; but-ha! ha!I mind me not of hearing a mountain sing. And the winds of the West, they moan and hiss, and sometimes they swirl across the desert sands like demon-ghosts in frenzied flight, but who shall say that the wild winds sing? In their roughest moods they rasp me, and if they whisper low they never soothe my harried heart. The fearsome voice of the wind haunts me like the sighing of some lamented chieftain's ghost. Mountains have no melody for me, and the winds that blow across their shaggy brows sob and moan and sigh, but to my sad soul they never sing."

"Hist! Silence!" said the Piute. "The Great Spirit may have secrets of song that mortal musicians have never known. My chieftain sire surely heard the old Truckee Mountain sing. Many times I've heard him tell such tales around the wigwam fire. And in my memory I am hearing it now, as of old. Wewoka, will you hear the mountain sing? My chieftain sire said it sang a song of civilization. Listen! A sound of music is on the wind. It is the mountain singing, the old Truckee Mountain: 


\section{Meadow and Mountain}

I sing of the mine-camp's busy flume, Of silver, gold, and coal,

Of cascades leaping in mountain gloom,

And rivers that swirl and roll;

I ing of a land where the love-lorn day

Lingers in after-glow,

Where the sun's sweet light scarce fades away, Till winds of the morning blow.

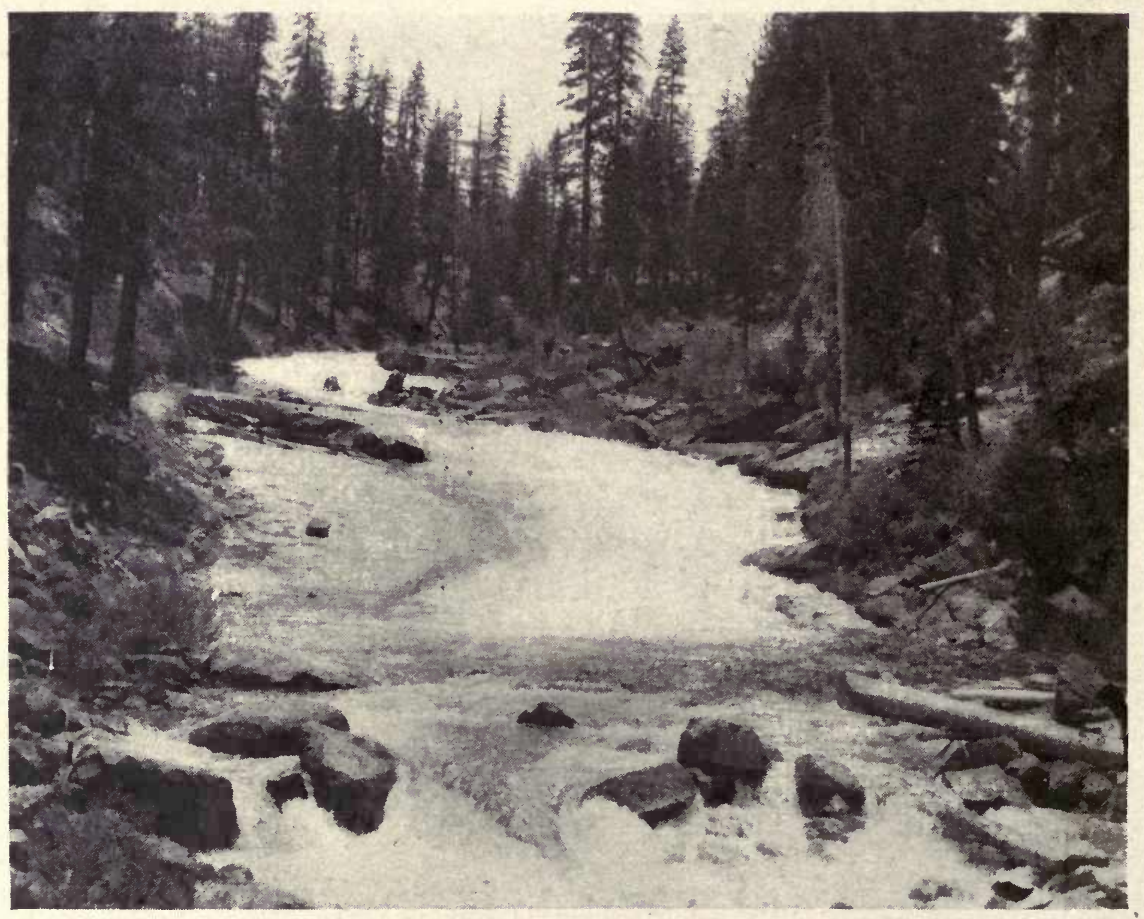

“AND RIVERS THAT SWIRL AND ROLL" 


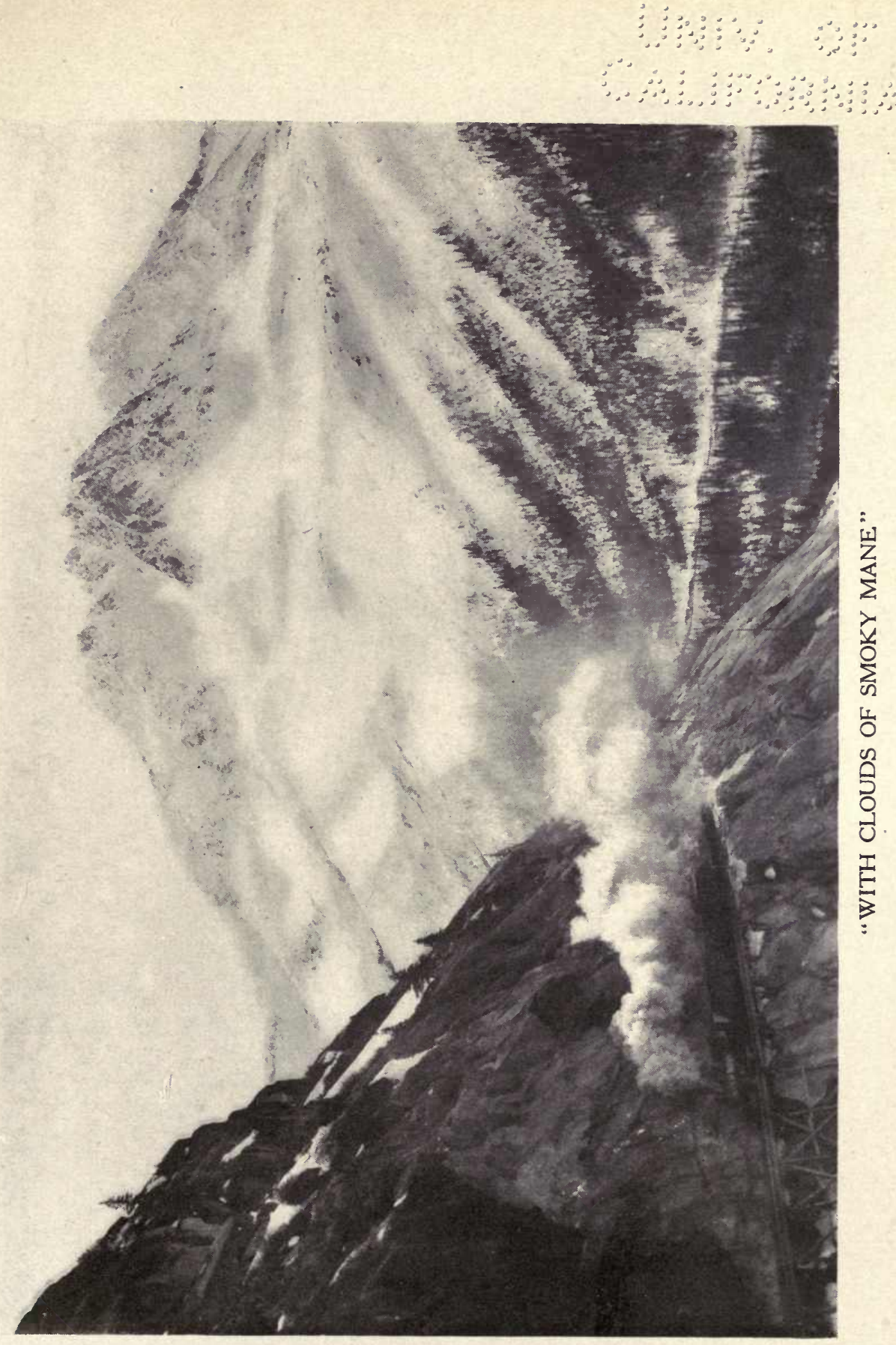


$\because \because \vdots \quad \because \vdots \because \vdots \vdots \vdots$

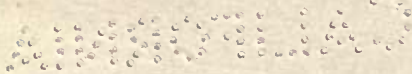




\section{A Dream in the Desert}

I sing of the fiery horse of steel, Flying across the plain,

Over a land of wealth and weal, With clouds of smoky mane;

Of the mills' and factories' toilful roar, I sing in reposeful strain;

Of fragrant fields all covered o'er With gifts of sun and rain.

I sing of the sand dunes clad in green That once were brown and bare, Of fertile vales that stretch between, And the homes that nestle there;

I sing of the happy bride and groom, I sing of the wealth-filled mines,

I sing of the orchards draped with bloom, I sing of the stately pines.

I sing of the limpid springs that flow From the icy hearts of hills,

From the beautiful drifts of eternal snow, And laughing in lovely rills;

I sing of the numberless herds that graze

On the boundless grass-grown plain, Of luscious fruits and the oily maize, And the wheat-fields' golden grain.

Through all the singing a wistful look had been in Wewoka's eyes. Long-forgotten things had once again returned, and memory in his eyes and on his face was playing hide-and-seek with them. "It is a song about the things of which I used to dream," he said. "The song has stirred again faint hints of hope. Now I know that mountains can sing and winds can carry messages. But these hot sands and this dreary desert seem far away from the green fields of that 


\section{Meadow and Mountain}

song-story. I fear me this is only a delusive dream. You have sung to me, good Friend, about the scenes of civilization. Still I feel that the reality of it must be far away. My feet are blistered. My lips are burnt. My tongue is thick for want of water. My limbs are weary with fruitless wanderings. My eyes are dim with distant looking. Close enough to hear the song, but far enough away to die without the solace of the singer.

"Dear Piute, it is time for dawn, but the darkness never seemed so deep. I can no longer catch the scent of the sage. Even the morning star has lost its splendor. Dear Piute, let me touch your hand, I can not see your face. Stir the tepee-fire-the dawn's breath chills me-"

Nay, it was not the sweet morning air that made the desolate dreamer cold. At day-dawn the sunset winds of life were blowing on the desert sands. Their chilly swiftness caught Wewoka's breath away, and the risen sun found the wanderer stretched in silence on a lonely couch of sage and sand. The desert was as still as Wewoka, save the faint strains of a song that was singing on the wind-

Oh, Musical Mount, thou hast taught me to know That the sweet winds of God rare music can blow From the edges of rocks under night-smitten sky, Till the soul of man drinks rhythmic life from on high;

Thou hast taught me to listen to voices that speak In the Holy of Holies from valley or peak;

To gaze from a crevice while God passes by

In shining Apocalypse trailing the sky;

Then hush thee, my Soul, and list in thy roaming, For the music of God that sounds in the gloaming, And let His good angels, Thy guests from on high, Stretch all thy life-chords in tune with the sky. 


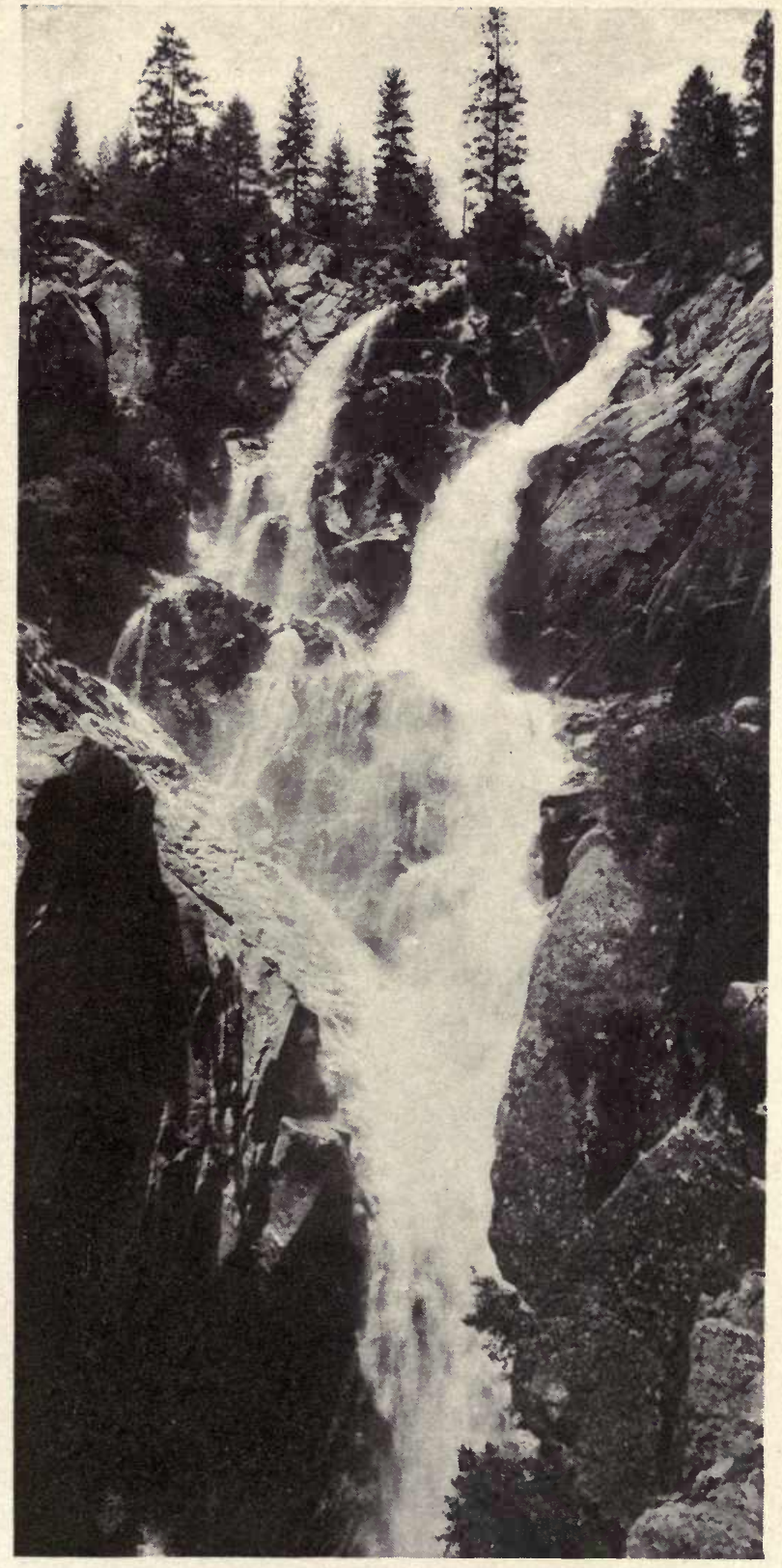

MUSICAL WATERS 


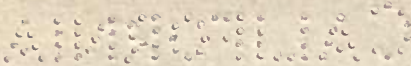



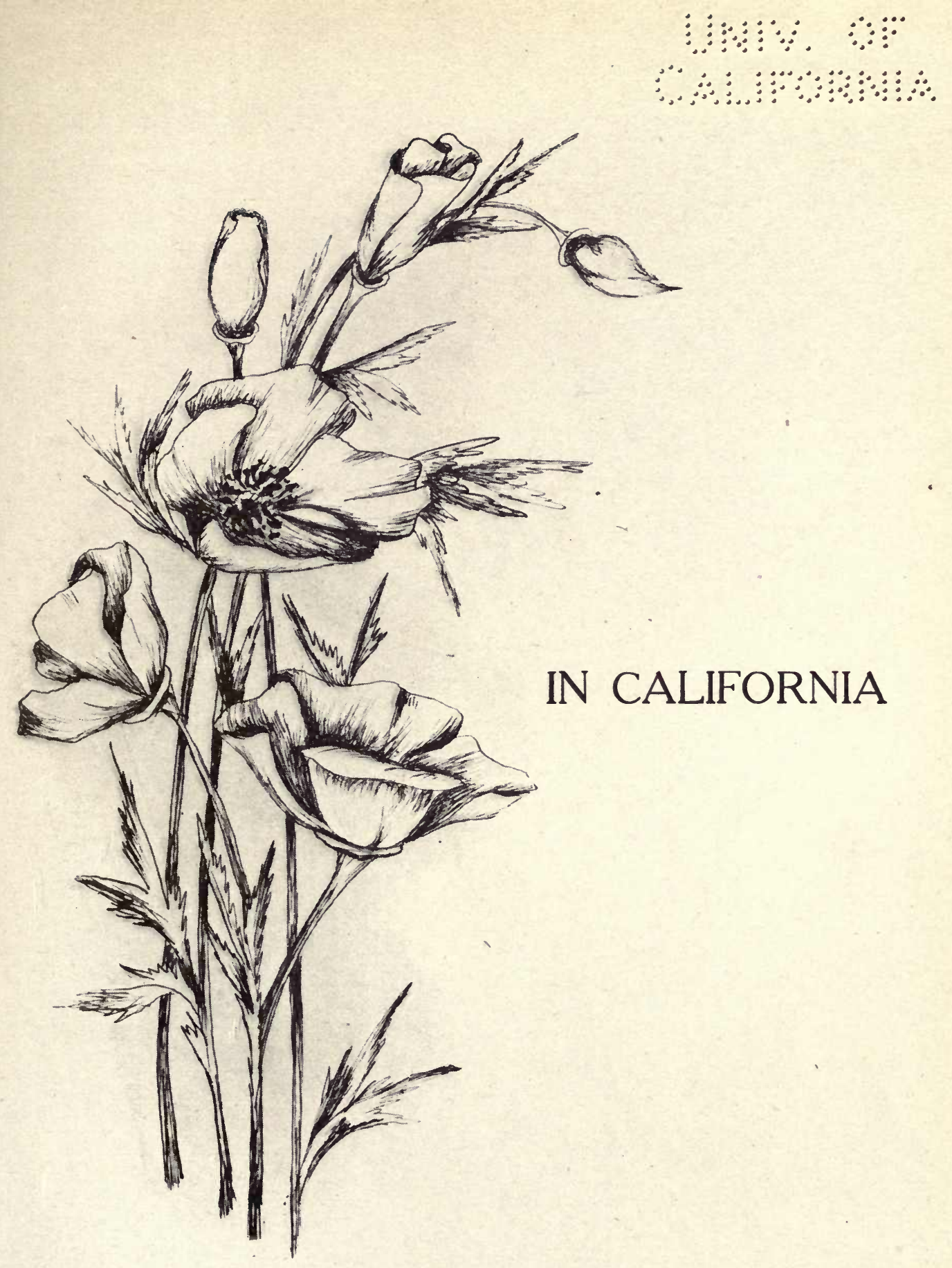
\begin{tabular}{lll}
3 \\
\hdashline
\end{tabular} 


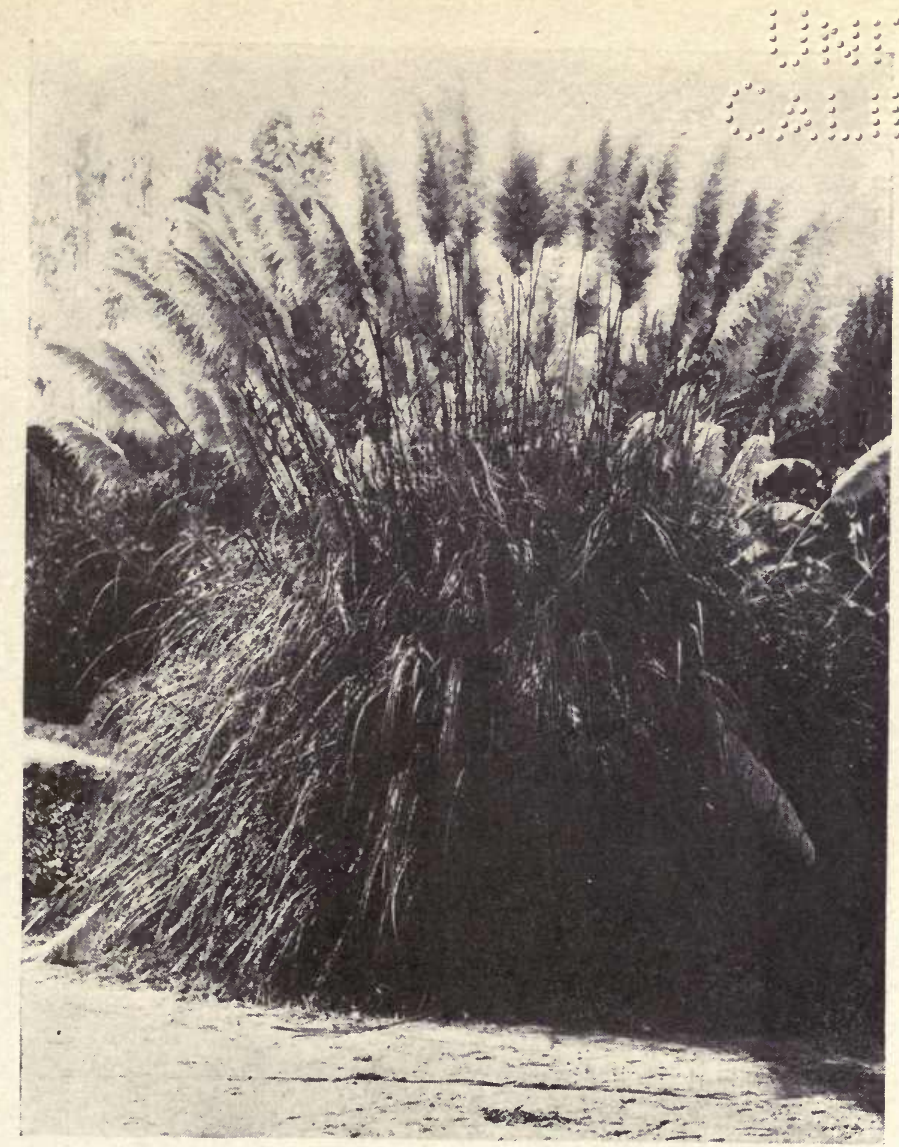

PAMPAS GRASS

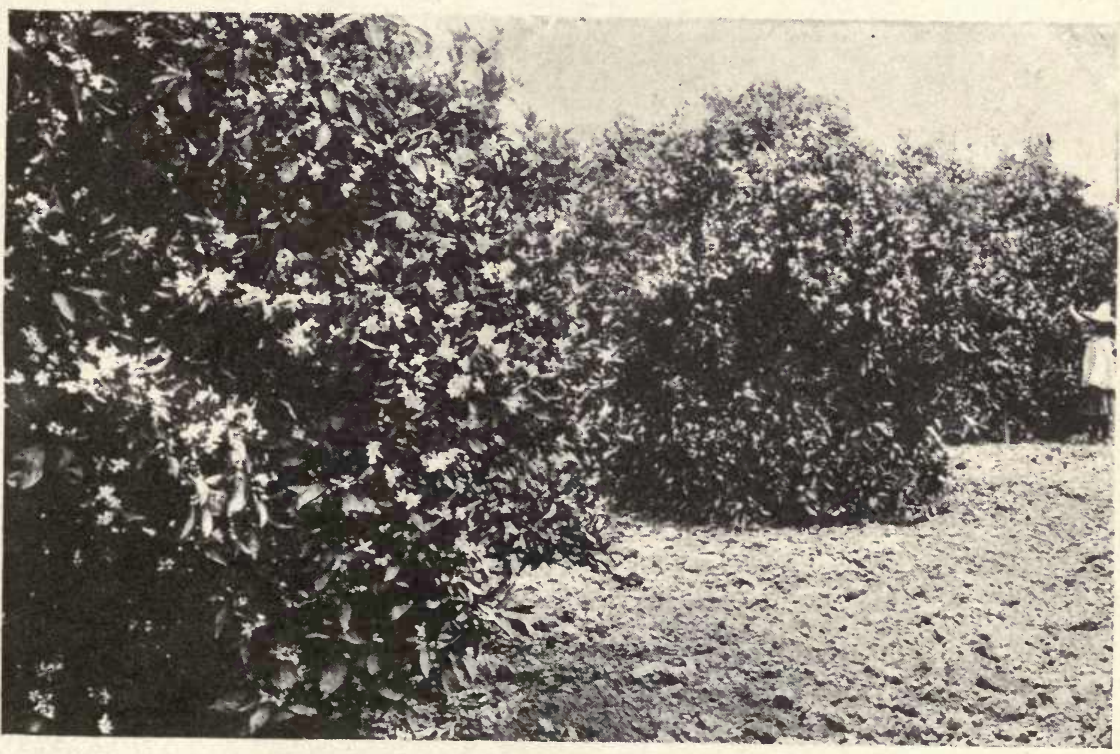


$\because \because \because \quad \vdots \circ \vdots \div \vdots \vdots$

$\therefore \vdots \vdots \because \because \because \because \because \vdots \quad \therefore \quad \therefore \quad \vdots$ 


\section{IN CALIFORNIA}

I have caught the gleaming goldAll my happy heart can holdFrom the sheen of smiling skiesIn California.

Through the still and stellar night, Mingled with the lunar light, I drink the soft distilling dewsIn California.

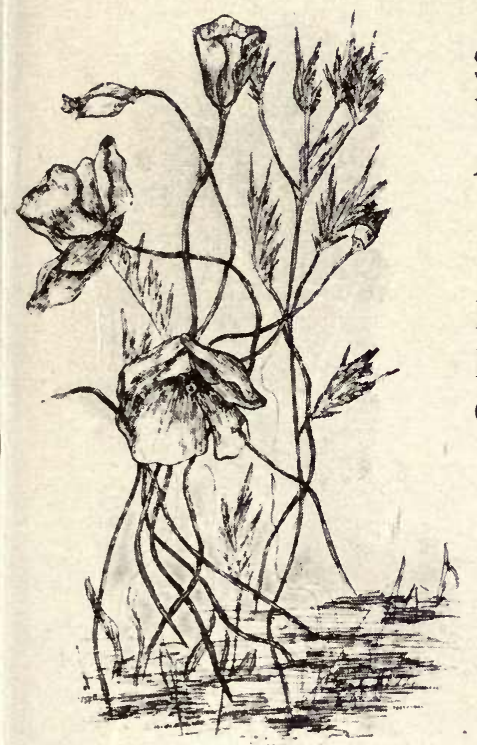

Showers of sunshine in the day

Wash my wrinkles all away,

And cleanse me clean as stainless skyIn California.

Flown afar is thy renown, Flower with the fiery crown, Clad in gaudy gown of flameIn California. 


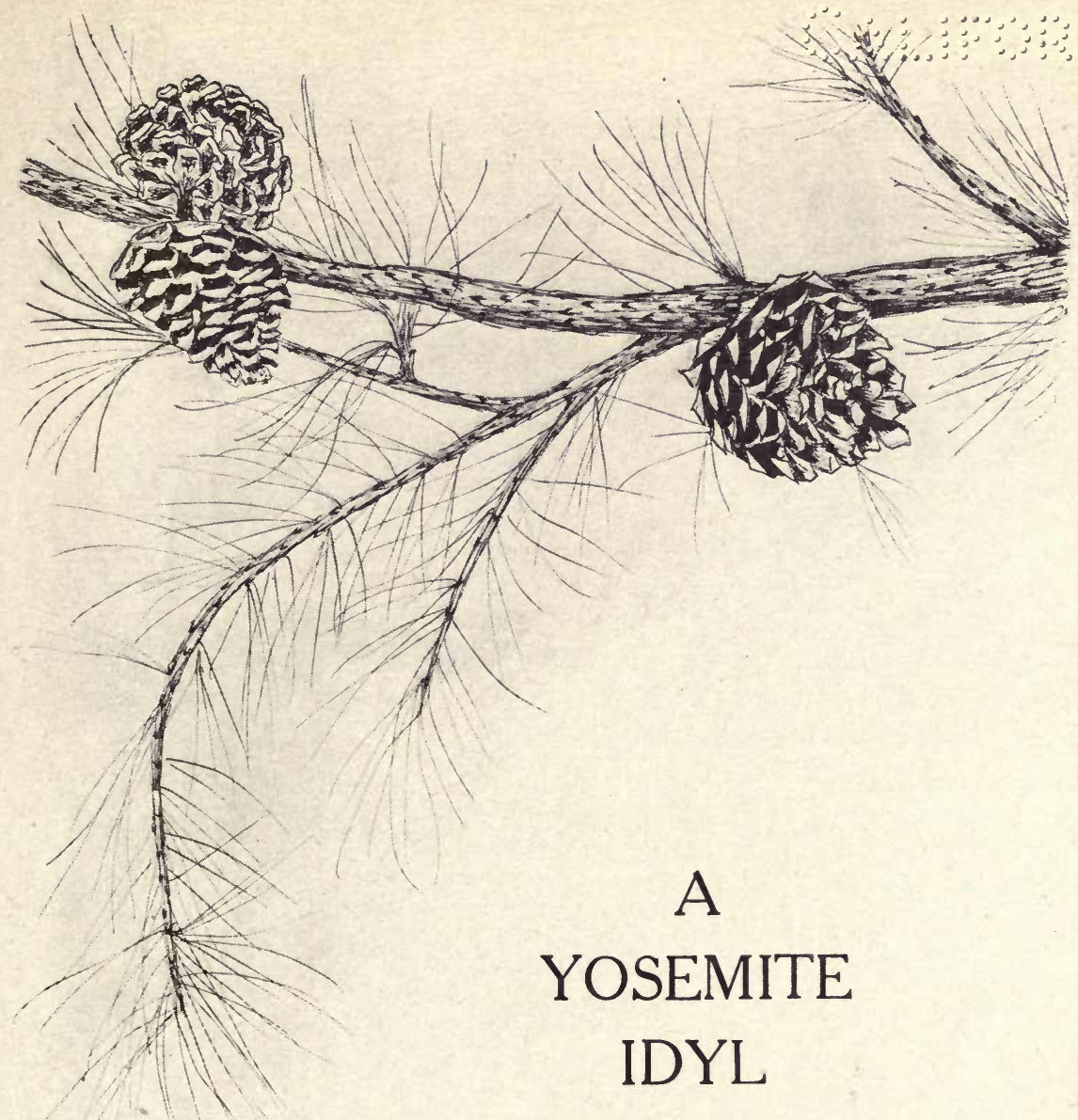





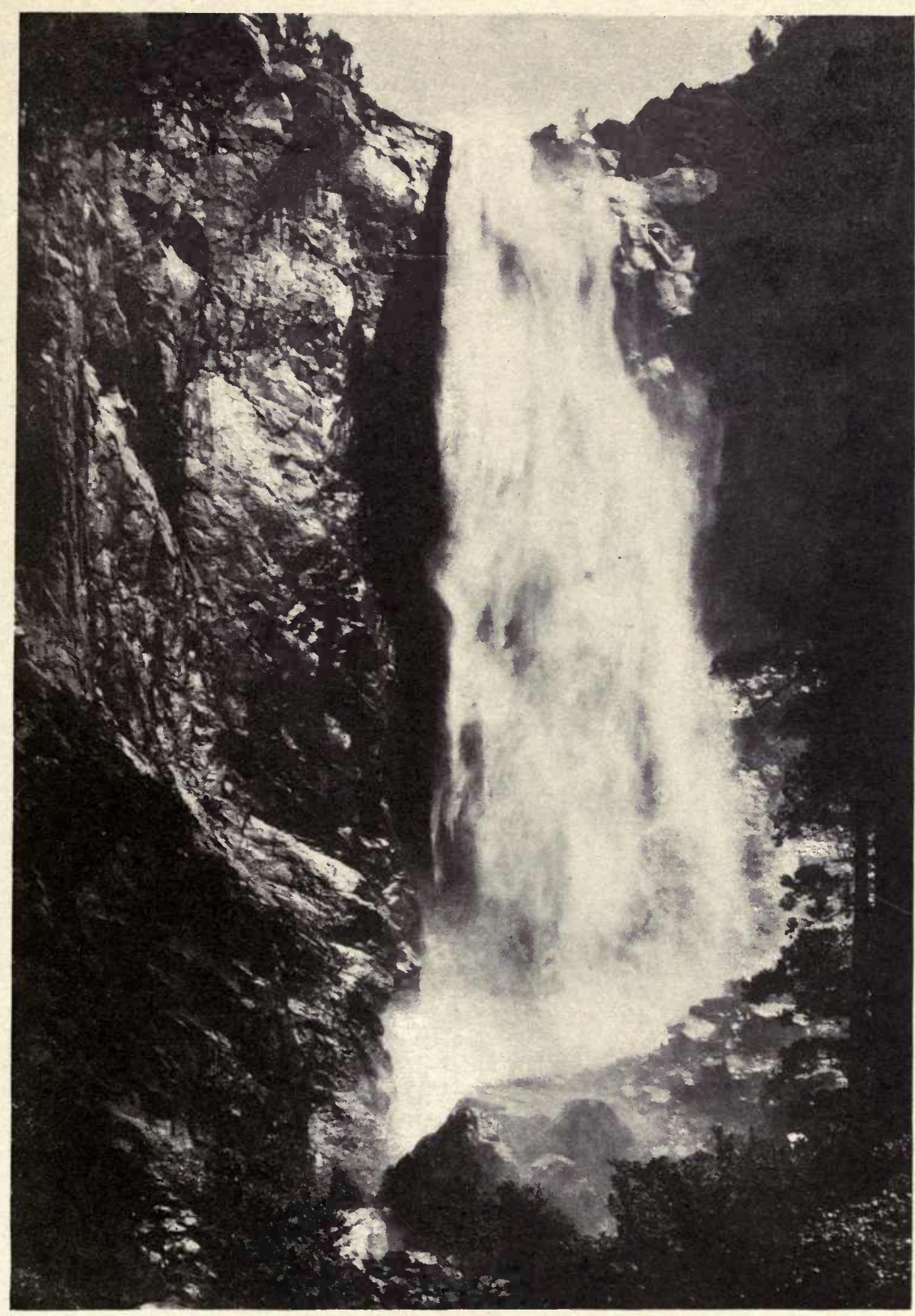

BRIDAL VEIL-YOSEMITE 


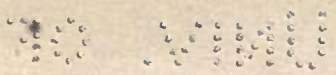

$\therefore \quad y^{2}$ 


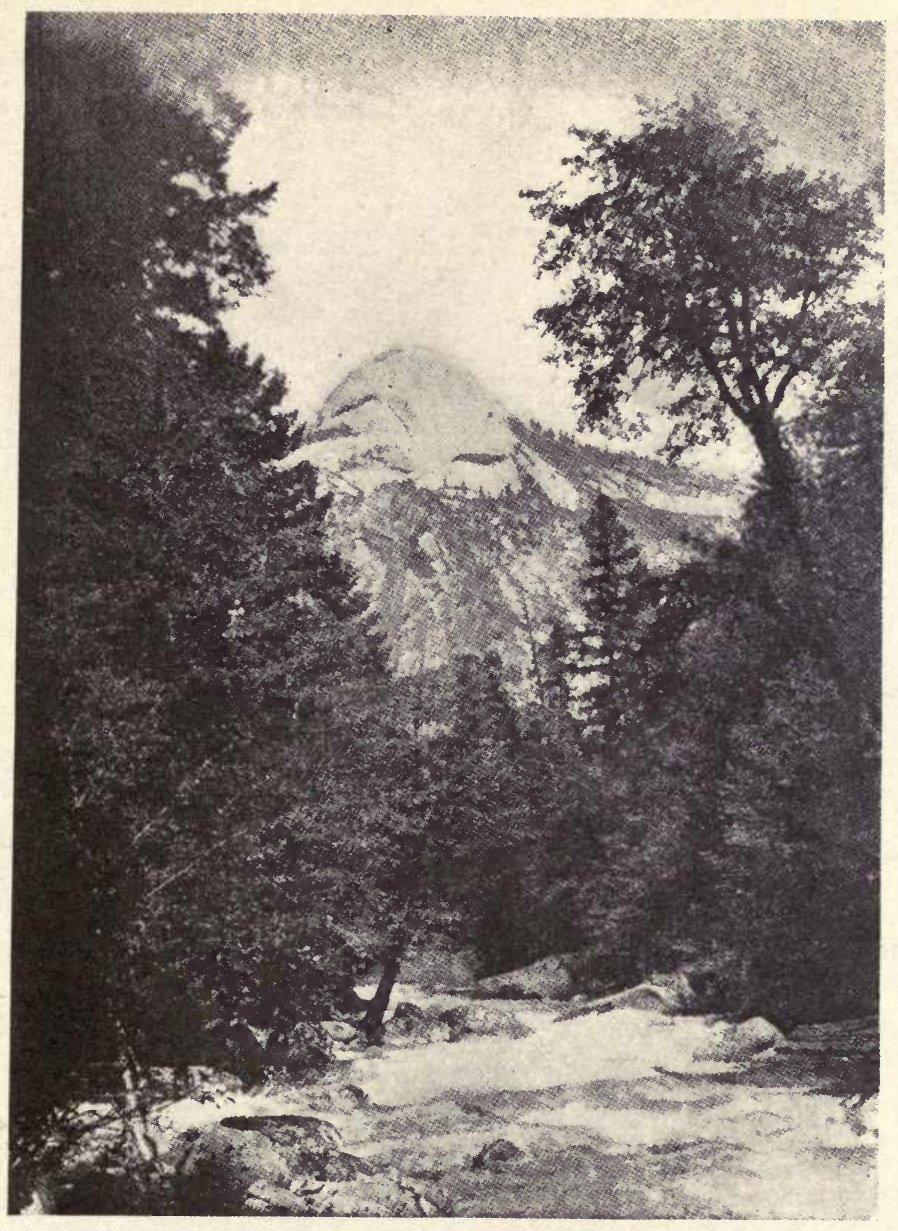

\section{NORTH DOME VISTA}

Graft and greed intrude not here Where Merced's flood flows cool and clear; Where healing mountain breezes blow Their music-breath across our woe.

And list! I hear the gladsome call Of some far-singing waterfall; I hear the night winds as they pass With hurrying feet among the grass. 


\section{A YOSEMITE IDYL}

THE fresh fingers of dawn silently slipped aside the black robes of the night, and it was day. The same still fingers snuffed out the star-candles of the dark, for the sunlight had come full-flare. Dewdrops flashed in the valley like frostflakes in the sun. The green grass was agleam with the glory of light. Birds twittered and trilled and mingled their music with the beams of the morning. Dear old Yosemite is young again, for blown from her lips is the breath of the dawn.

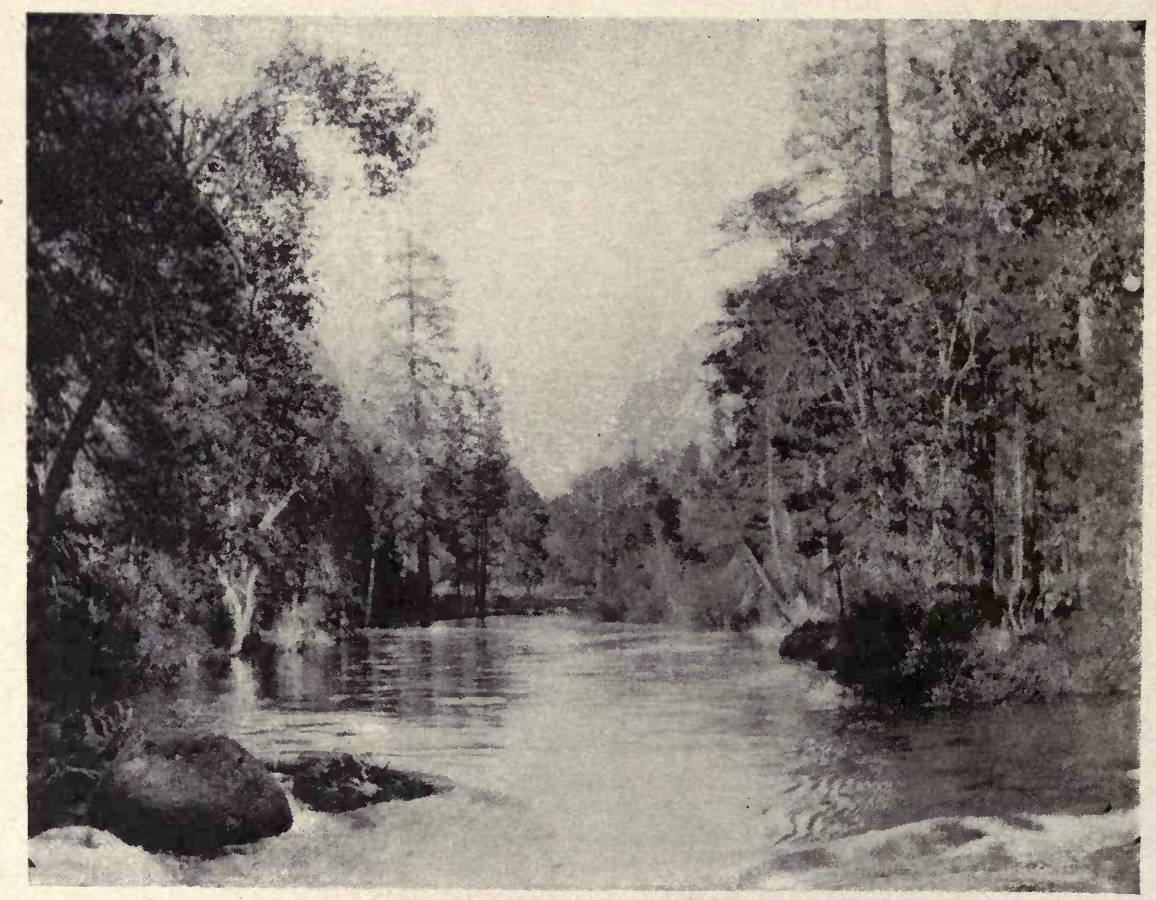

MERCED RIVER 


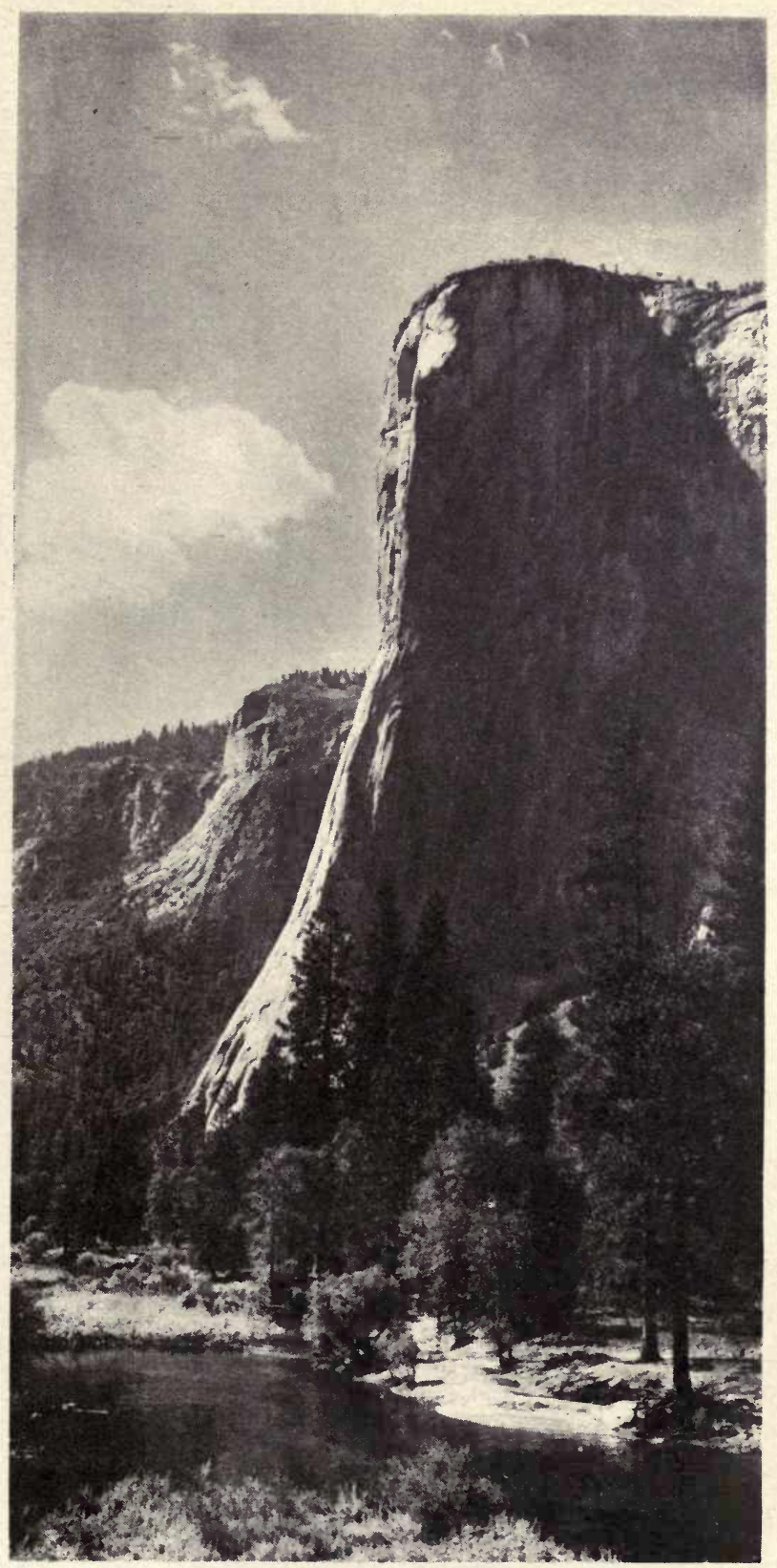

EL CAPITAN-YOSEMITE 



\section{A Yosemite Idyl}

The seams and the scars in the wrinkled old rocks are garbed in the glory of grasses and moss.

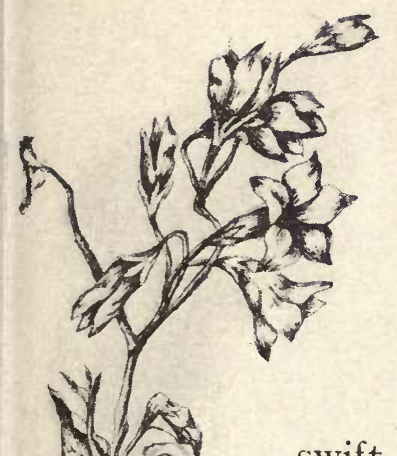

Flowers and ferns fall over bare boulders, each petal and frond adrip with the dew. The meadows are drenched with showers of sunshine, as the king of day climbs upward to his throne.

Bunches of azalea bloom hang their bewitching beauty above the babbling waters of the merry Merced as it laughs and leaps swift away to the sea. I catch the cadence in my dreams and live it o'er again between the dewfall and the dawn. Rhythmic river, I love you now, and shall forever and a day; singing, singing as you go, where the bright azaleas bloom.

It is old Yosemite grown youthful and gay mid the fragrance of flowers, the singing of birds, and the dews of the dawn. The spirit of spring is the spirit of youth, and old

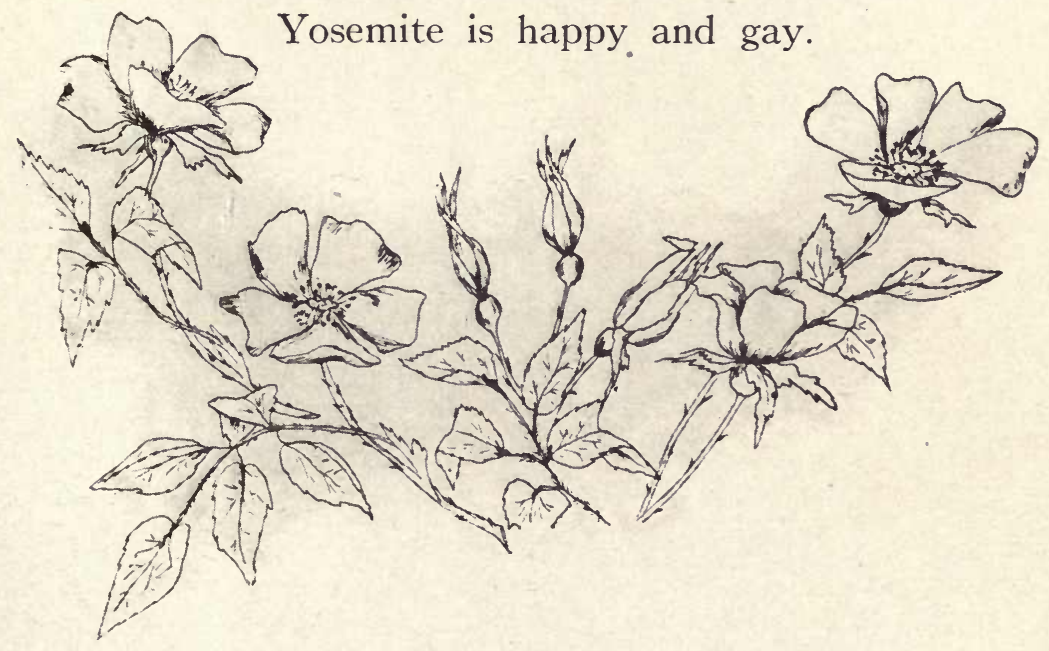




\section{Meadow and Mountain}

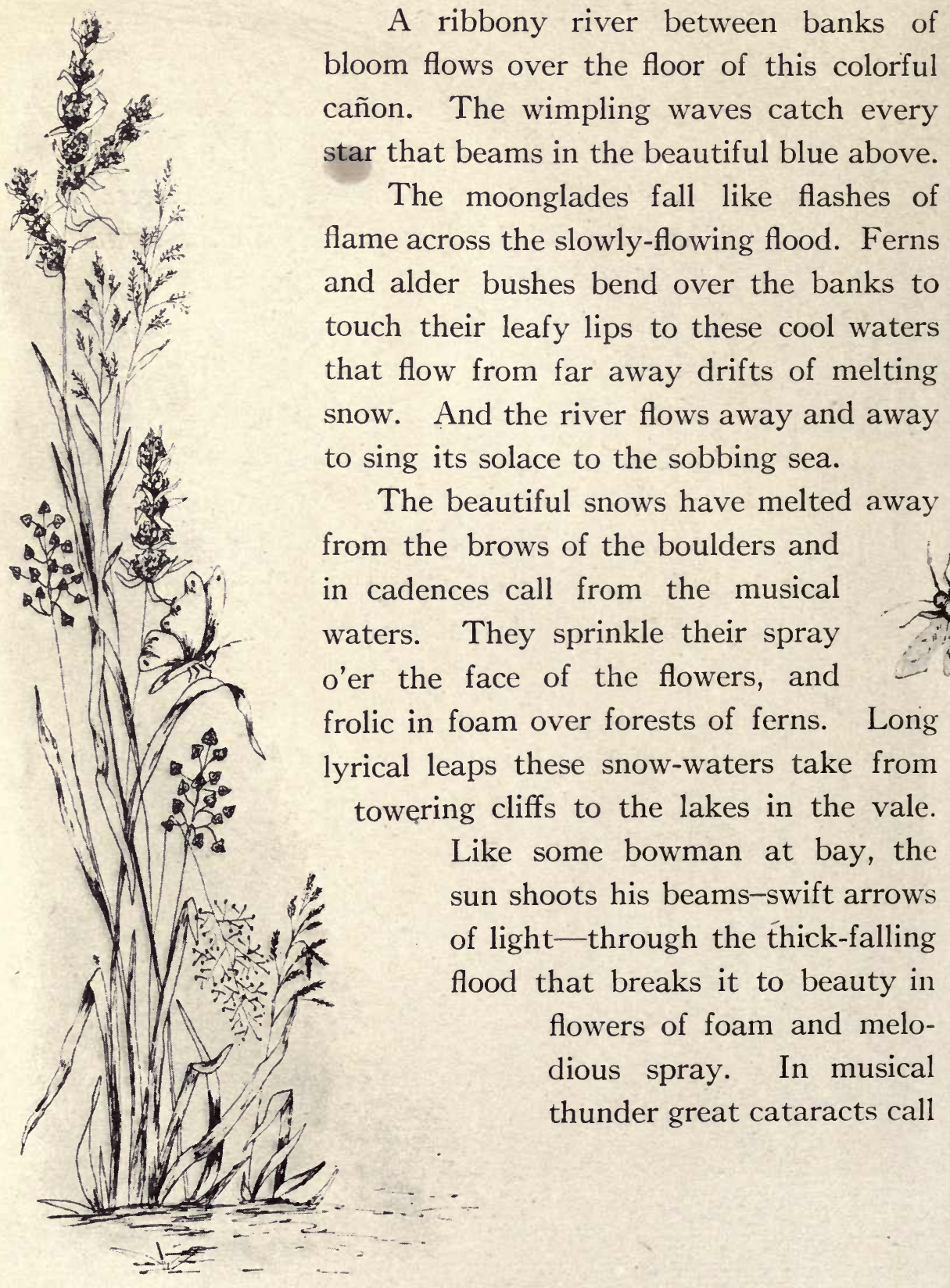



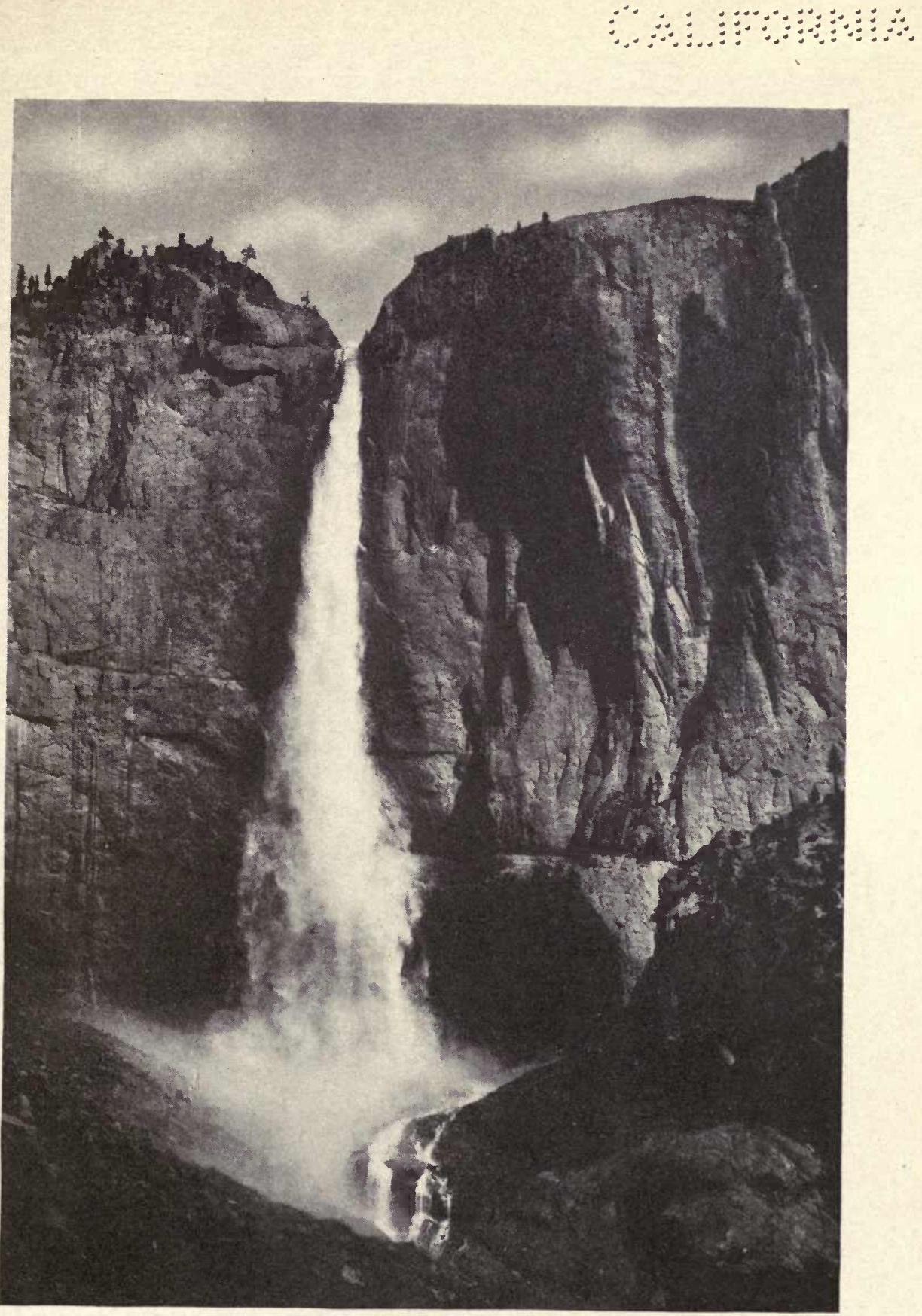
$\because \because \quad \because \vdots \because \because \vdots$

$\therefore$ 等 


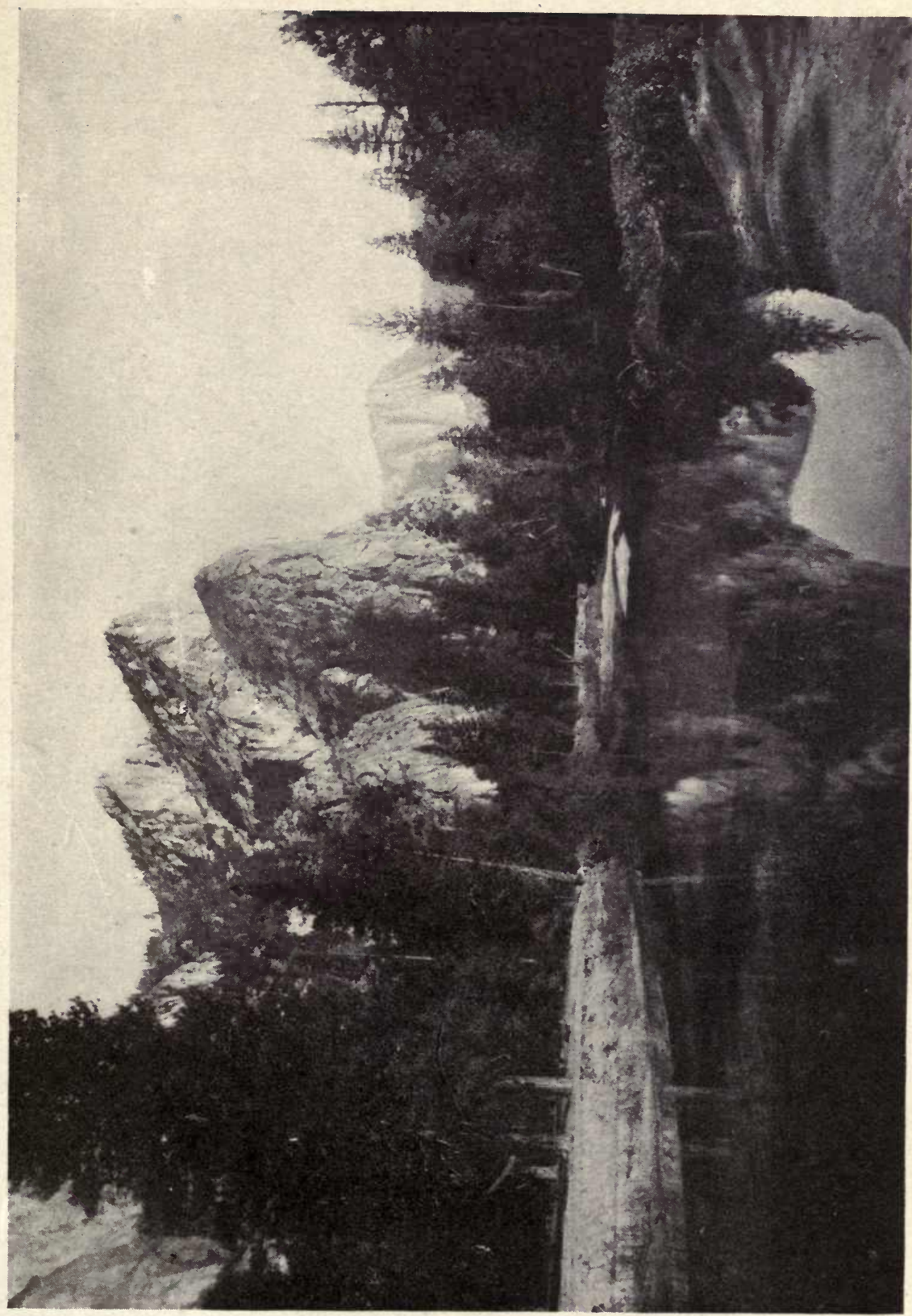

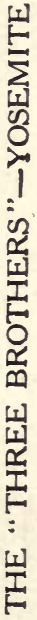


$\because \because \quad \because \div 3 \div$

$\therefore 40$ 


\section{A Yosemite Idyl}

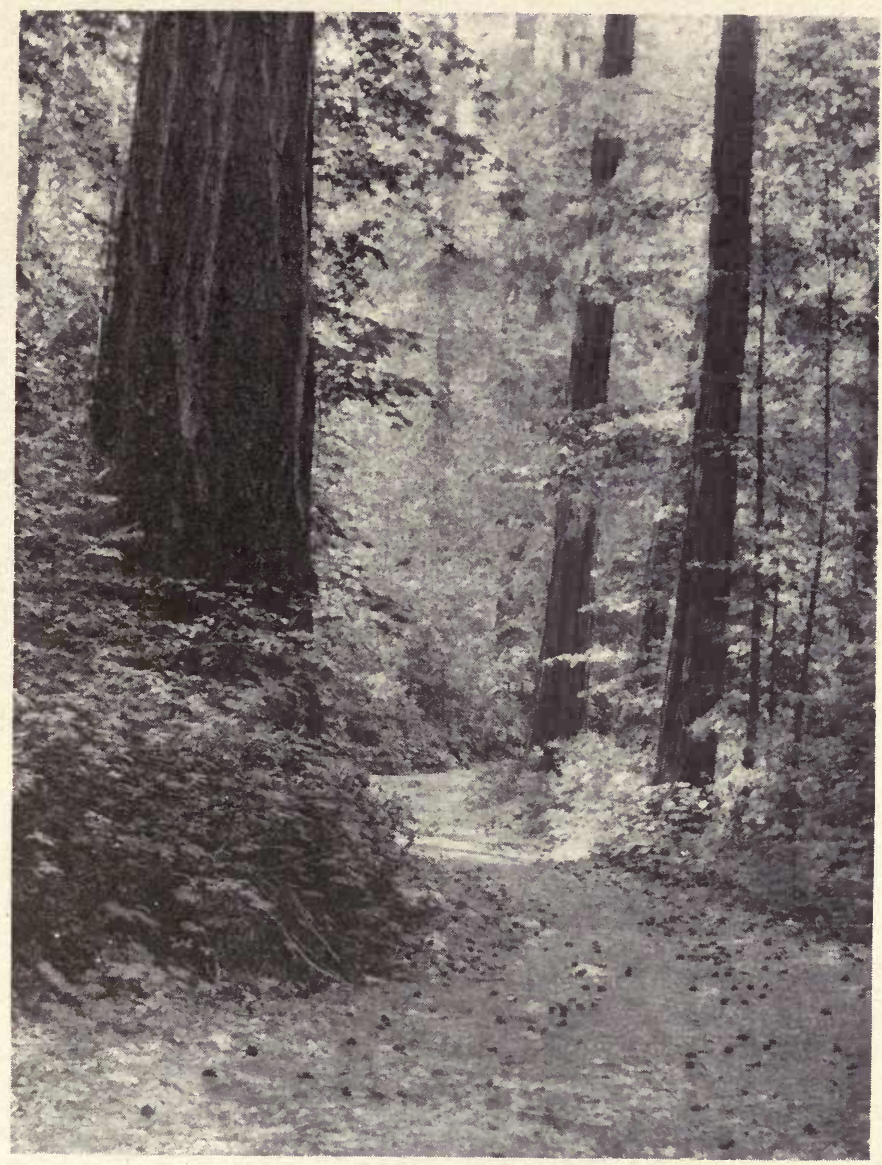

LOST ARROW TRAIL-YOSEMITE

like giants hard-hunted by foes from the hills. Deep calls unto deep in the gleam and the gloom as the soft-falling feet of the years hurry by.

The lakes have lured waters from mountainous snows and circled them round with beautiful lines. They bathe the bare feet of the cedar-clad hills as if they were pilgrims long waiting for rest. 


\section{Meadow and Mountain}

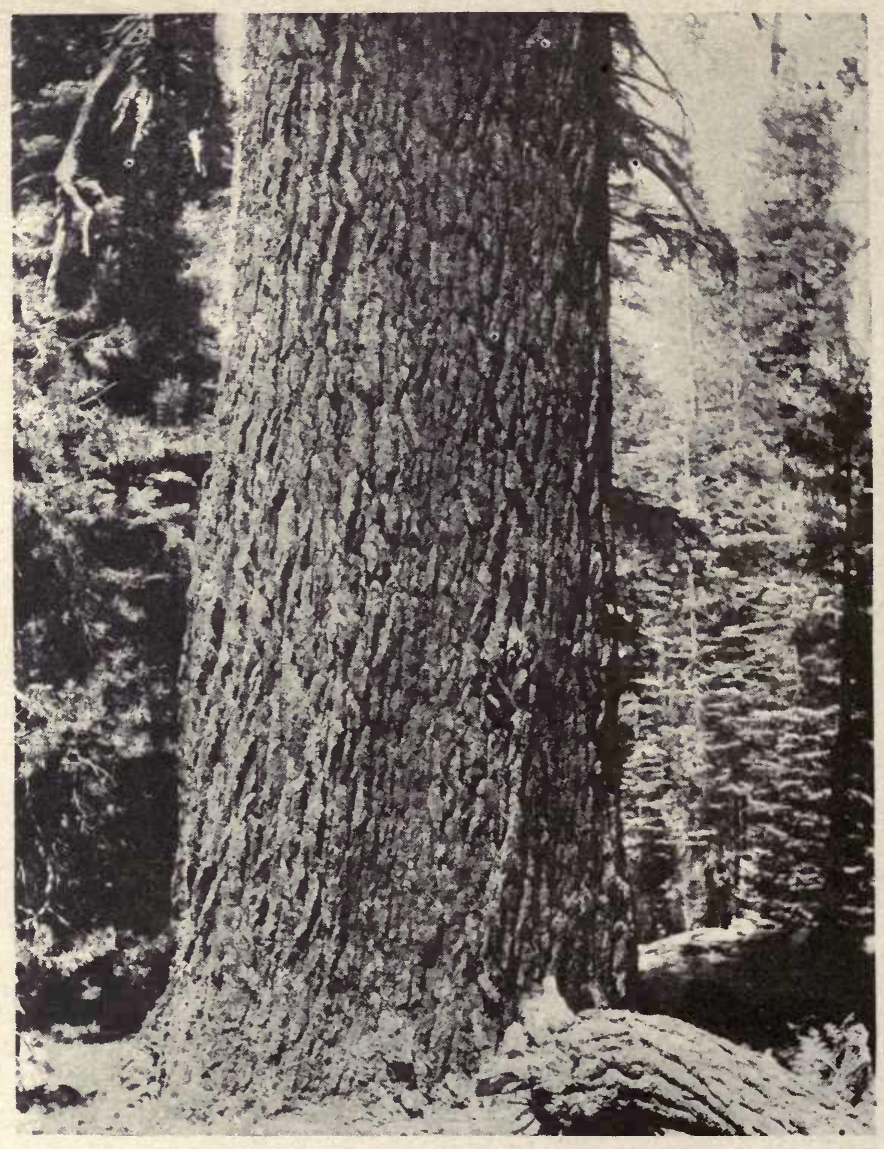

SPRUCE TRUNK

Bewildering beauty, mysterious music, splendors and shadows, clouds and clear skies, booming thunder of cataracts, muffled music of singing spray, bewitching wonderland of the world-Yosemite!

Overhanging skies as soft and still as if from their silences had never come deafening thunders to awaken the 


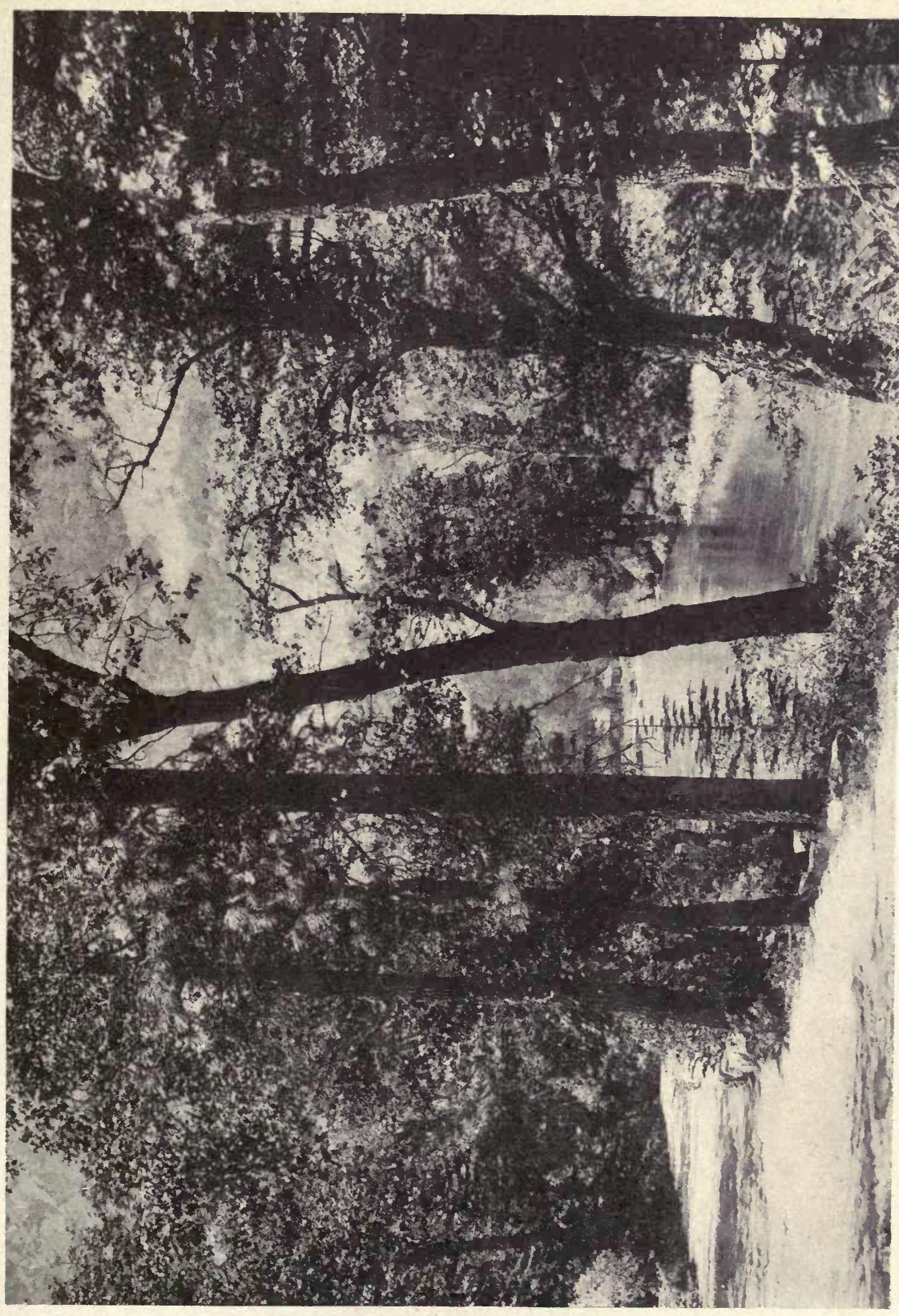


$\because \vdots \vdots \quad \because \vdots \vdots 00 \div$

$\therefore \vdots \therefore \therefore=\square \vdots \therefore \square$ 


\section{A Yosemite Idyl}

hushed hills or the sleeping forests; as if the black shadows of night had never been cloven by shafts of thunder shot in stormy fury across this yawning chasm of the Sierras; as if no tempest's battle-breath had ever blown its fighting flame through these ranks of soldier-trees.

The shadows sleep along the slopes as if the mountain winds had lullabied them to their dreamless rest; and peace is on these lofty hills, and peace is on my heart. The poesy of God is on these peaks and every pulse-beat is a prayer. Praise ye Him, ye mighty mountains, and praise ye Him, my soul!

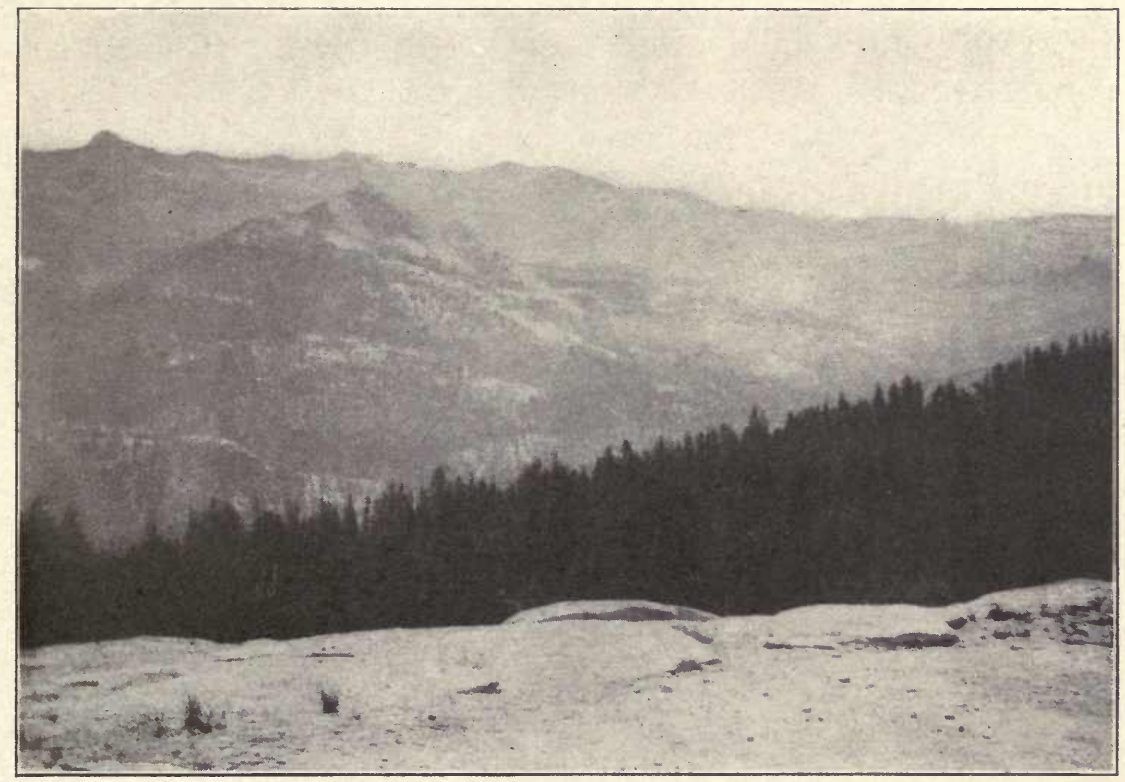

"THE SHADOWS SLEEP ALONG THE SLOPES" 


\section{Meadow and Mountain}

Moonlit meadows lie in dreamless sleep. When dusk is on the world and dew is in the wold, the moonlight falls like sifted silver in the dells. With soundless step it creeps into the dreaming cañons from over the towering cliffs. It shoots its shining shafts across the falling and foaming thunders of cataract and waterfall. At hide-and-seek ten thousand moonbeams play across the tarns and trees.

The shadow-shod feet of the night slip noiseless among the sedges of the marsh, and the wind's wet wings, freighted with fragrance of flowers, fold them down in the moonlit meadows to rest.

Old Yosemite - as old as the stars that rain their radiance into thy night - could I tell the tales of thy tarns and trees, thy ferns and flowers, thy mosses and meadows, thy gleams and glooms; could I tell the secrets of thy tempest thunders and thy zephyr whispers, the deep darks of thy nights and the high lights of thy noons, the bliss of thy birds and thy bees, I should catch the clew to the life-lore of the ages and the love songs of the world.

Great Artist of the hills and the heart, of the mountains and meadows; Artist of eternity and of time, Thou hast gone this way of wonder and of wealth, and I have come after Thee to find Thy fragrant footprints full of beauty and of bloom. 

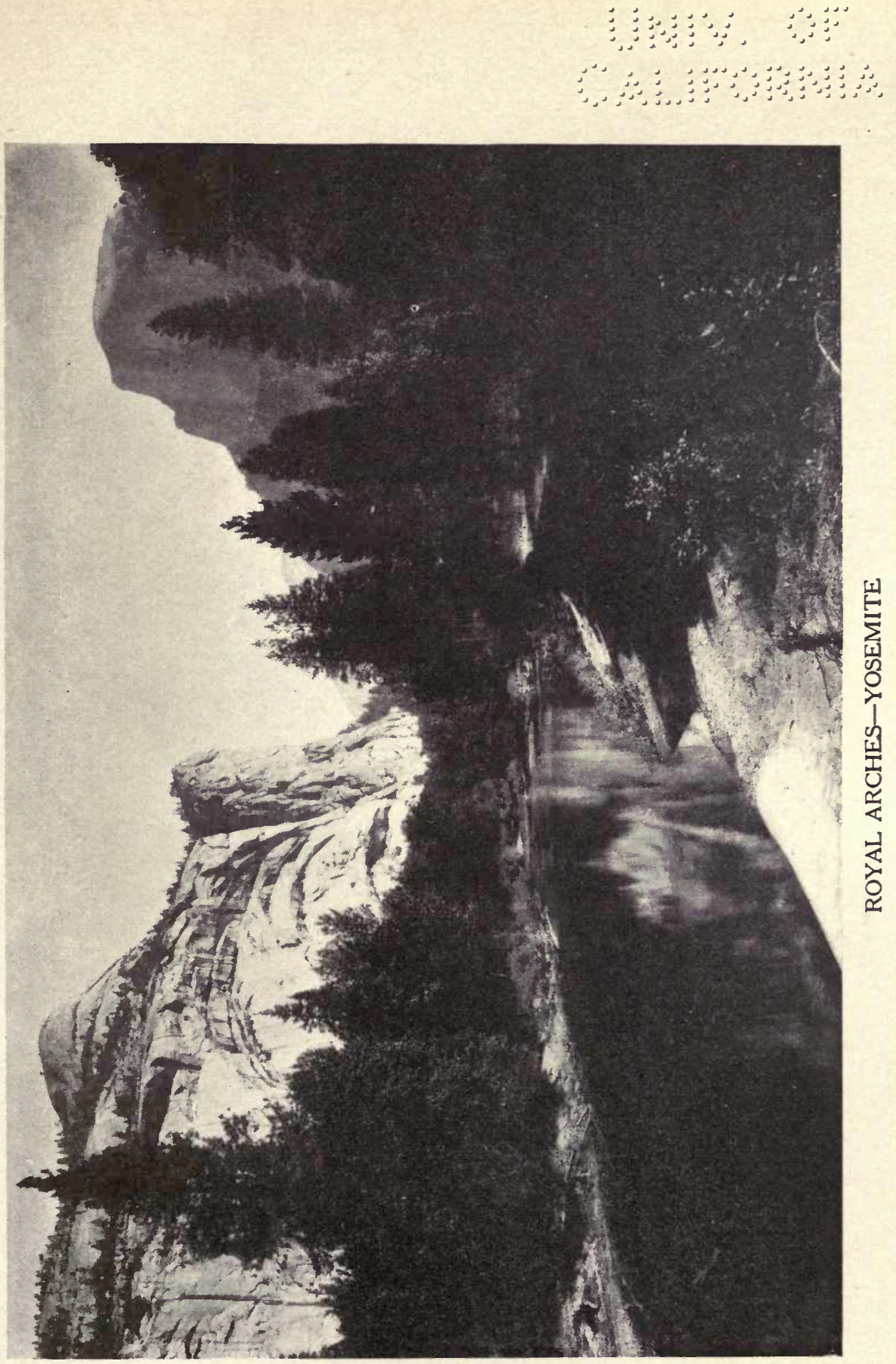



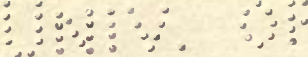

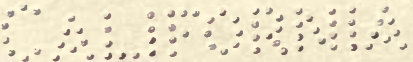

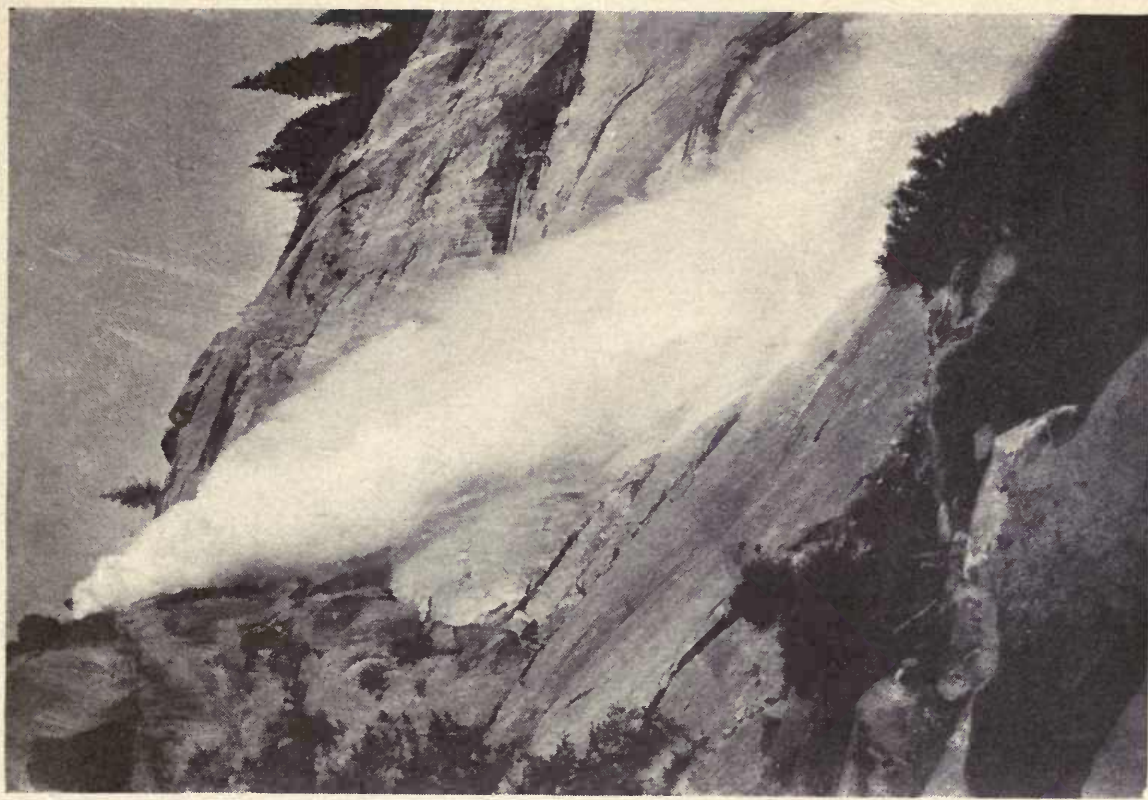

点

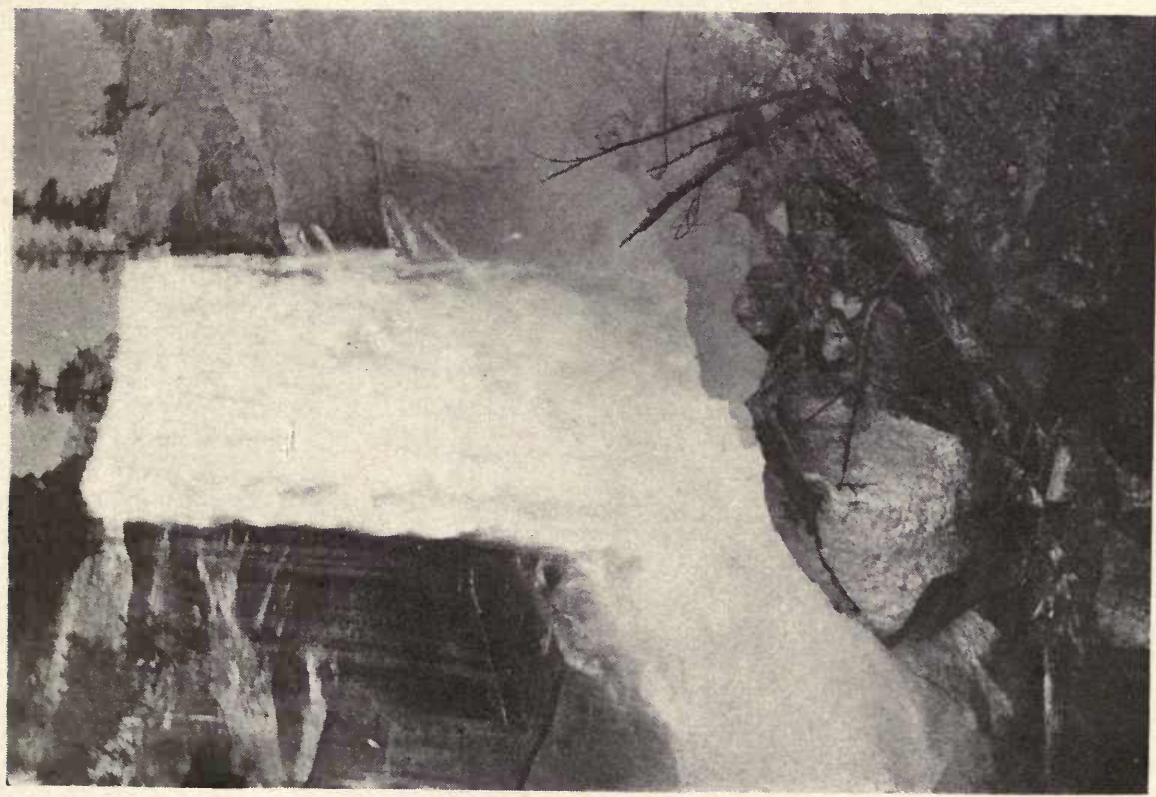

谣 
$\because \div=\quad \because \div 2 \div$

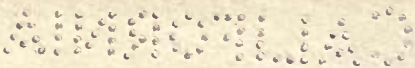



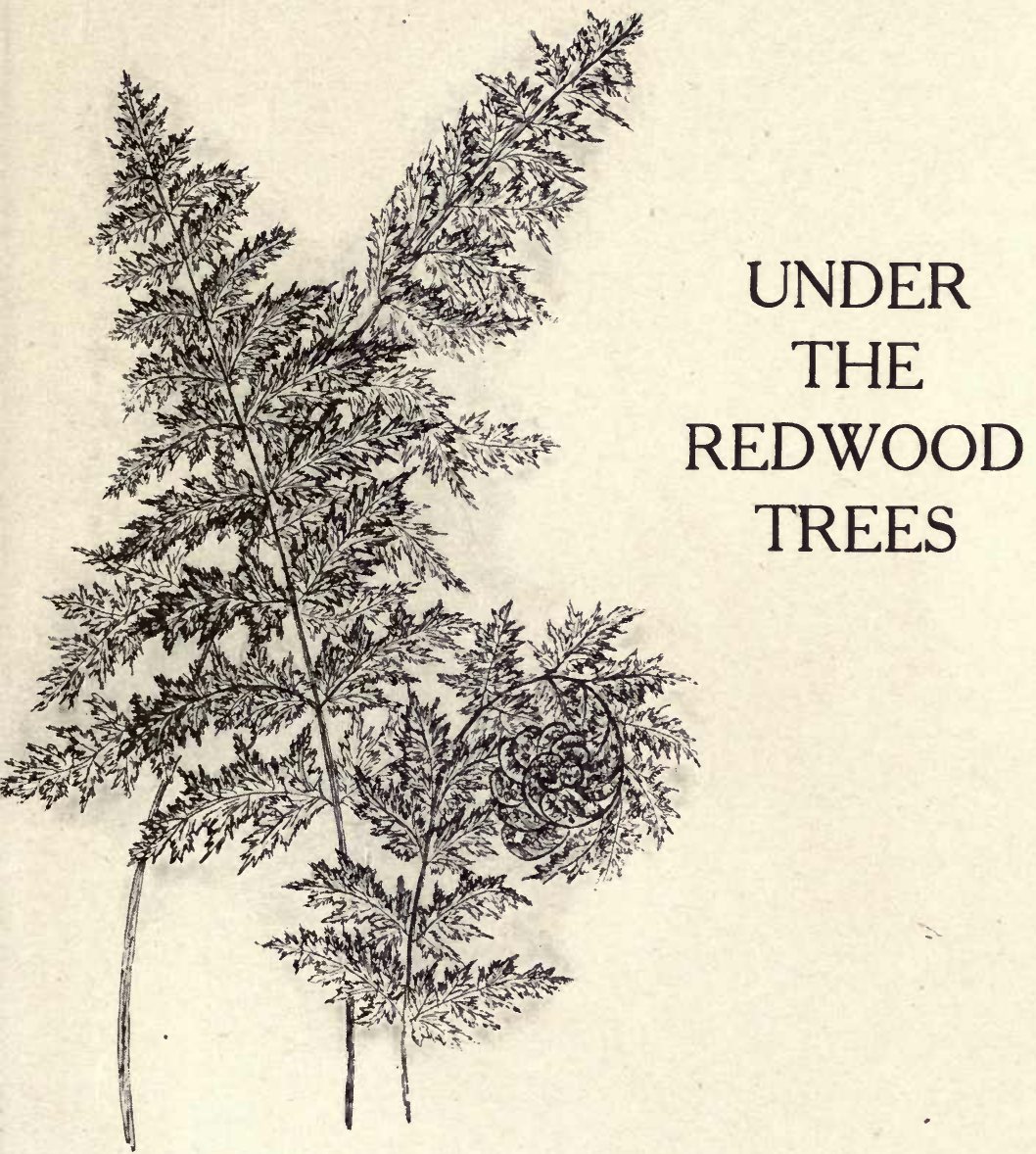
a 


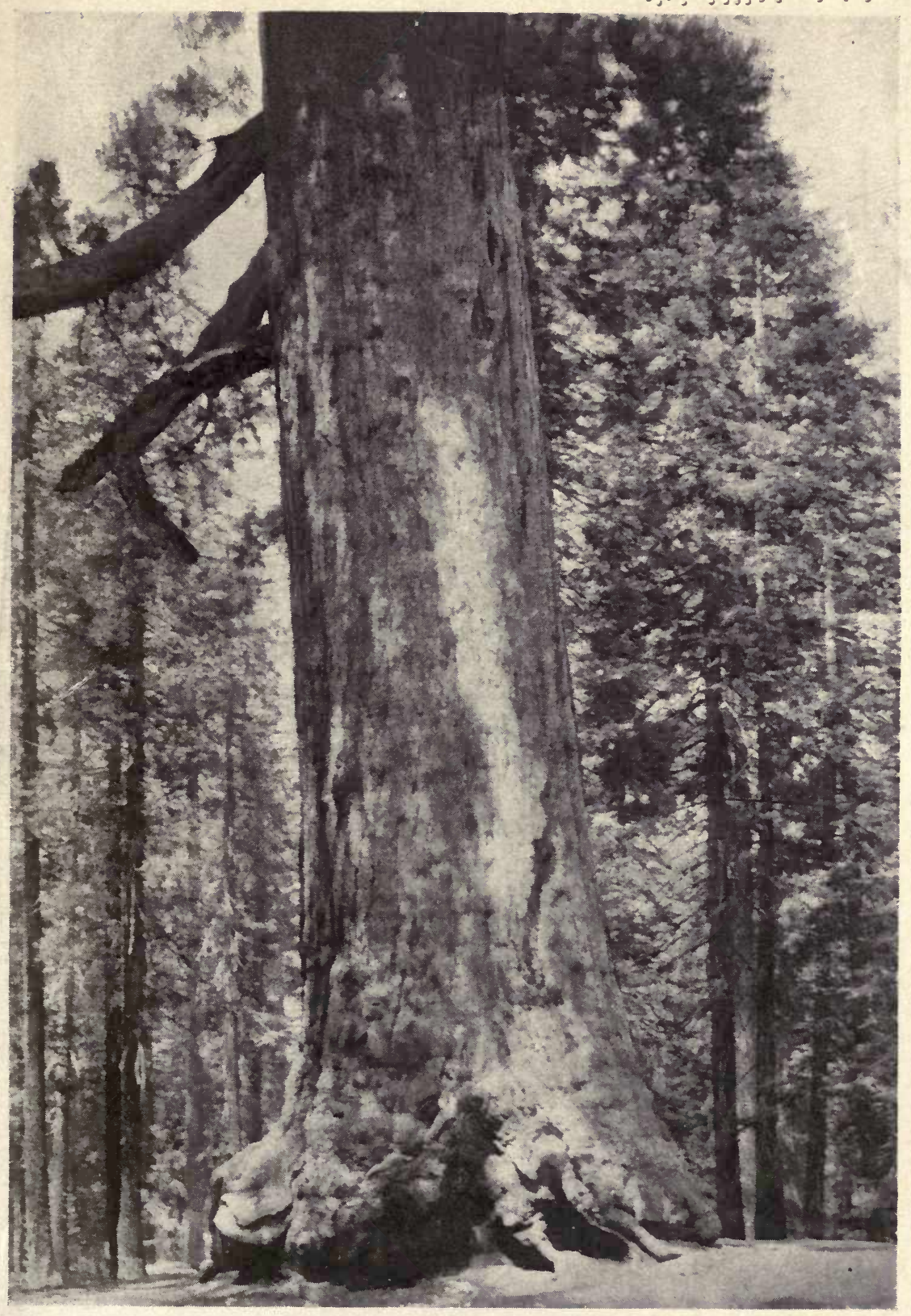

THE “GRIZZLY GIANT"-REDWOOD 
$\checkmark \quad 4$

and 


\section{UNDER THE REDWOOD TREES}

UNDER the redwood trees

The soothing shadows creep,

And softly woo the weary winds

To silence and to sleep.

Under the redwood trees

The slumbrous stillness grows,

And Time's old river through my dreams

Forever flows - and flows.

Under the redwood trees

Rest finds me once again,

And folds me in her mothering arms,

Far from the marts of men.

Under the redwood trees

I feel life's fevers heal-

And feel the freshening floods of life

Through all my senses steal.

Under the redwood trees

I hear the clocks of time

Count off the mighty centuries

With measured strokes sublime. 


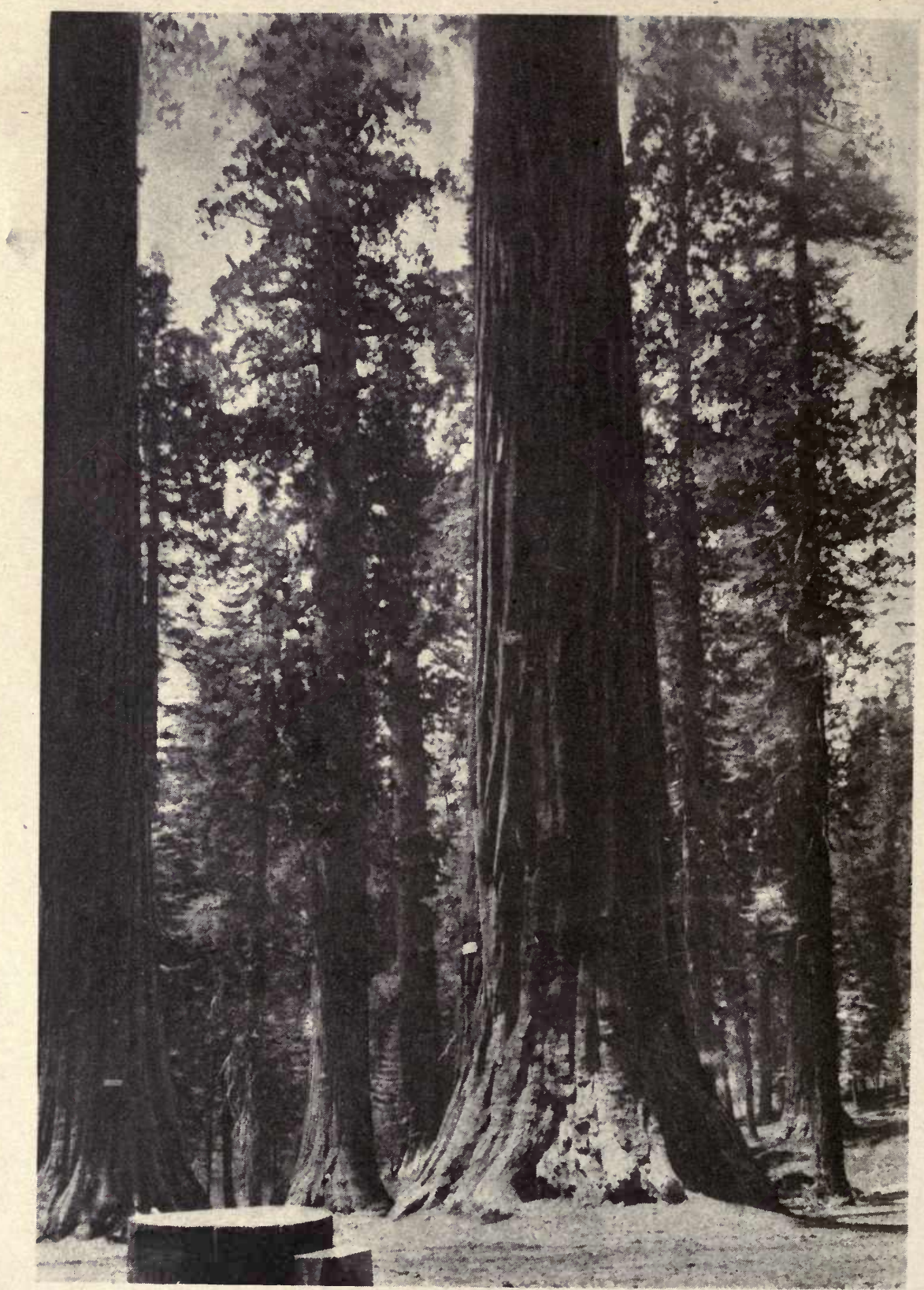

"Under the Redwood trees,

Old pilgrim years have trod." 


\section{Under the Redwood Trees}

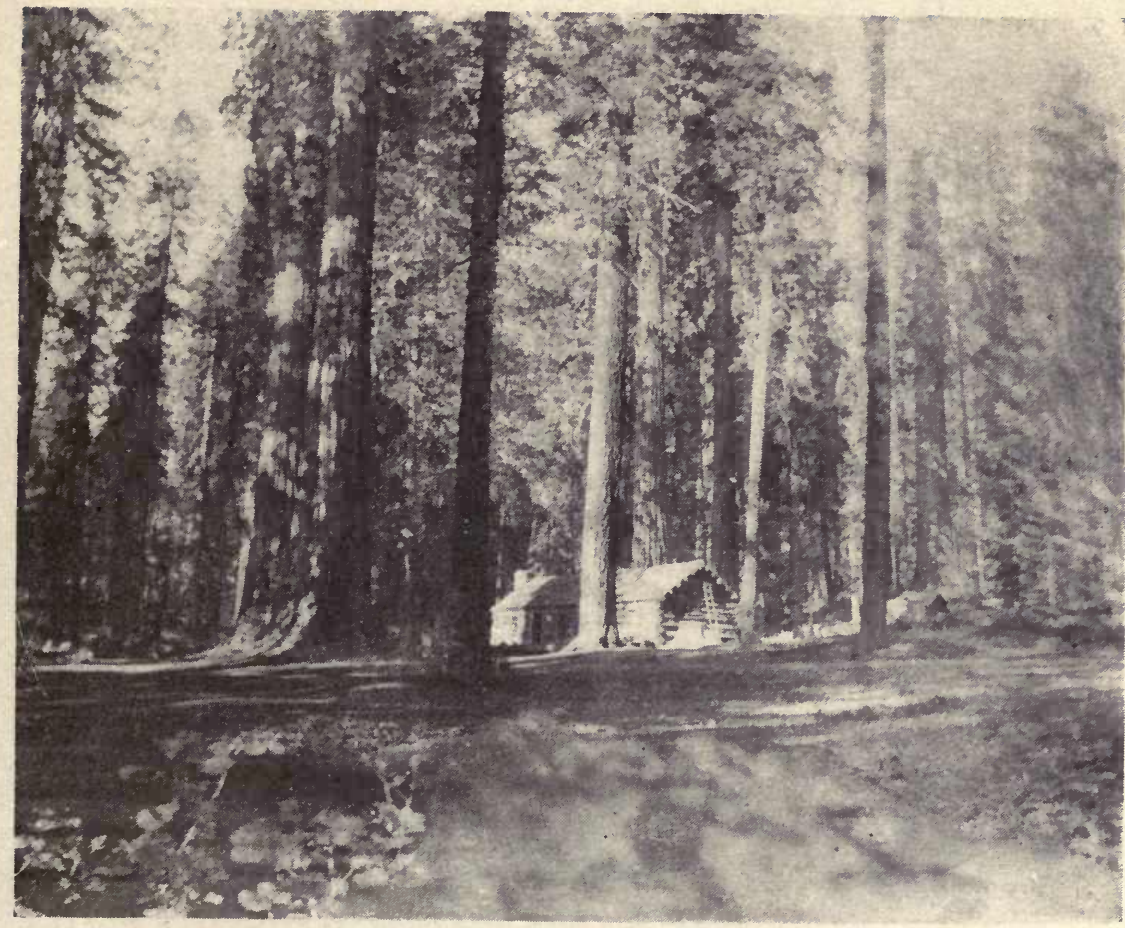

\section{REDWOOD TREES}

Under the redwood trees

I hear the ages sing

Of battles lost and scepters seized

From many a crownless king.

Under the redwood trees

I see the smiles and tears-

The panoramas of mankind

With all their faiths and fears.

Under the redwood trees

Old Pilgrim Years have trod

Their patient pathway long and steep

To find the Face of God. 


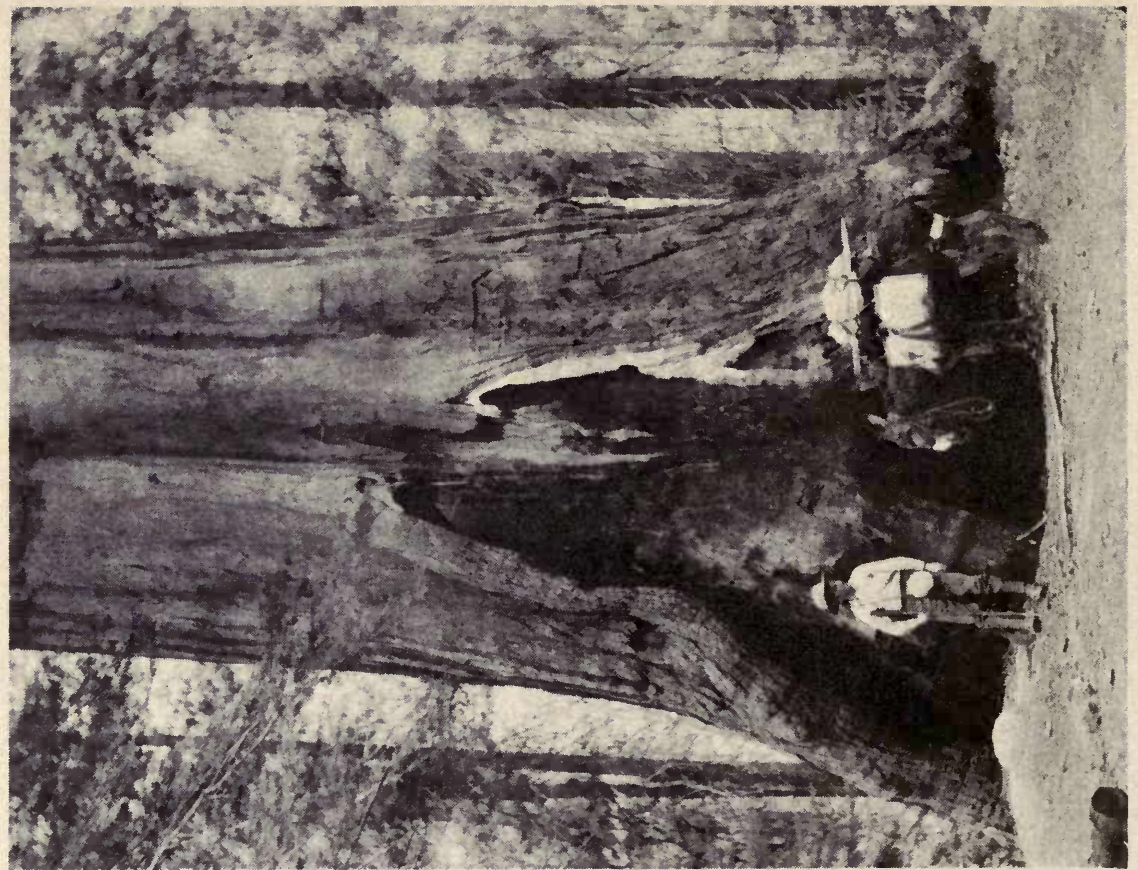

$\frac{n}{Z}$

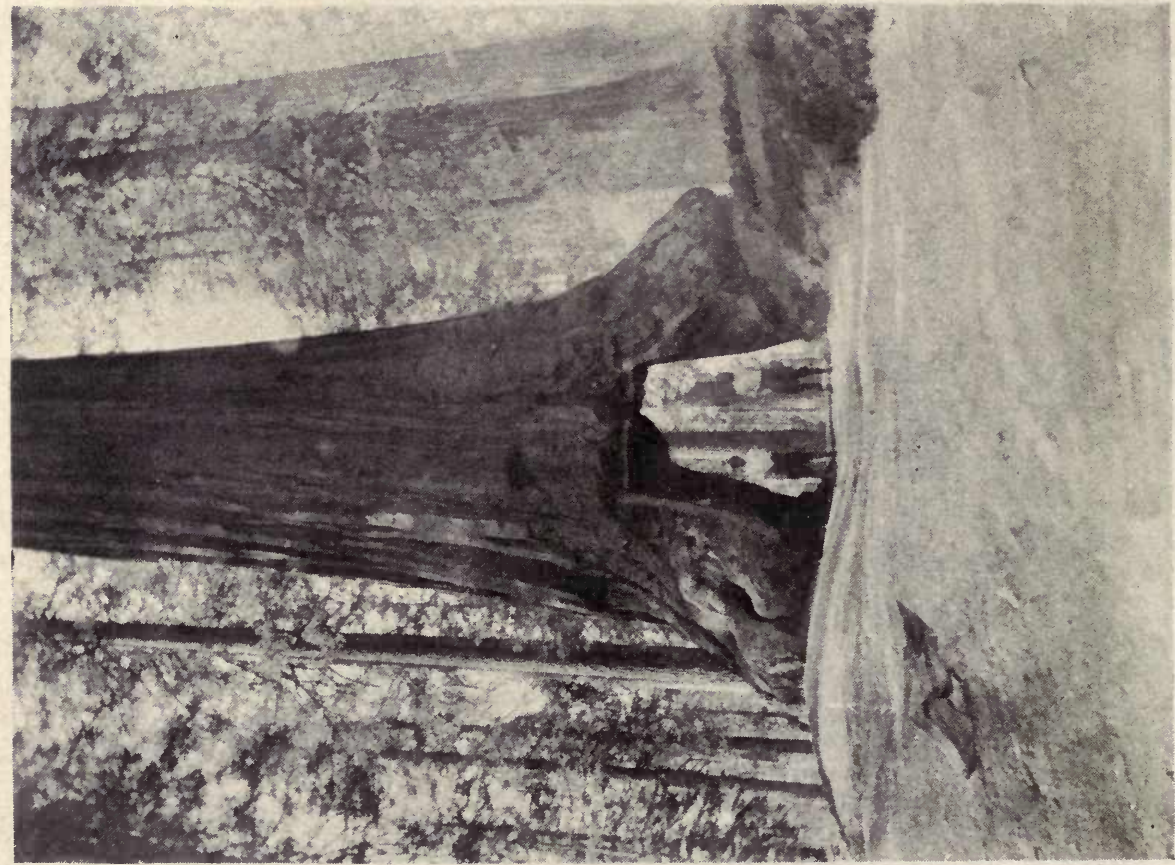




$$
\begin{gathered}
\vdots \\
\vdots \\
\vdots
\end{gathered}
$$

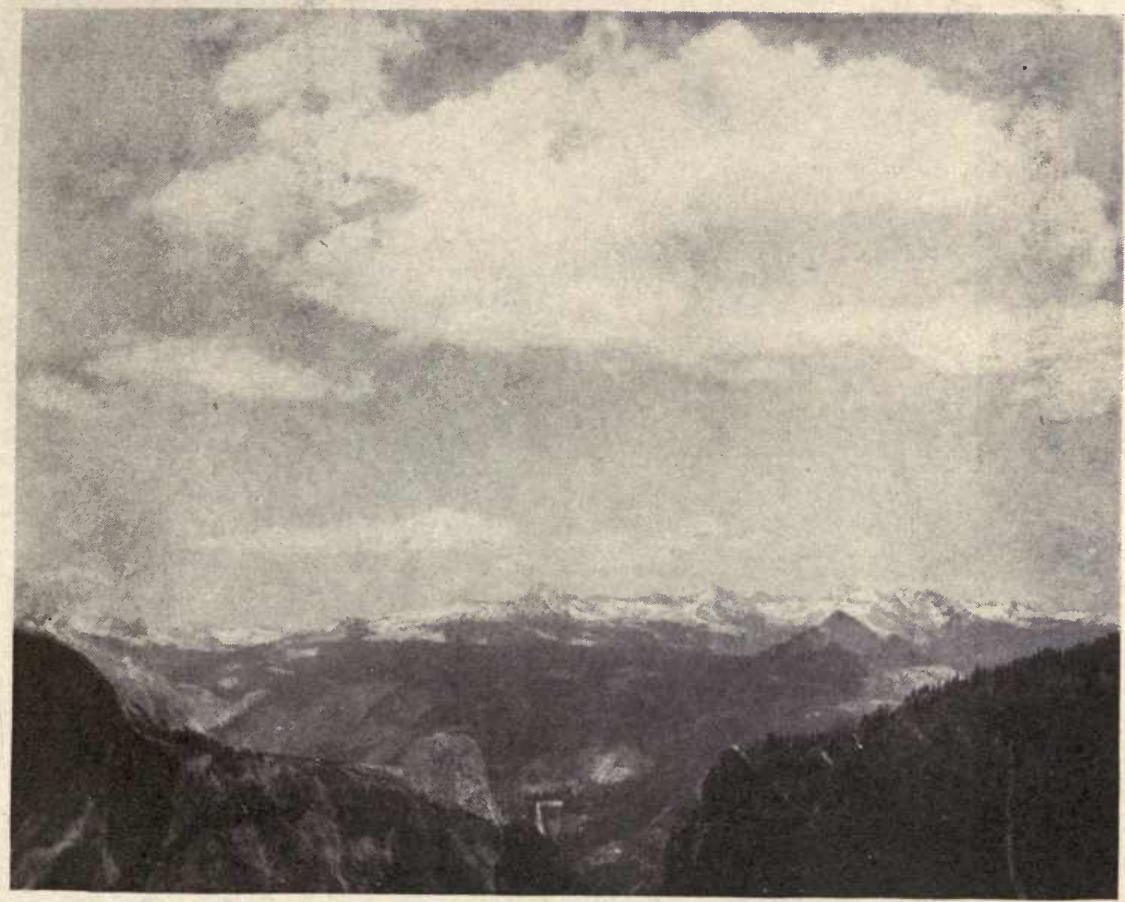

MORNING ON THE HIGH SIERRAS 

UNIVERSITY ON CALIFORNIA LIBRARY

THIS BOOK IS DUE ON THE LAST DATE STAMPED BELOW

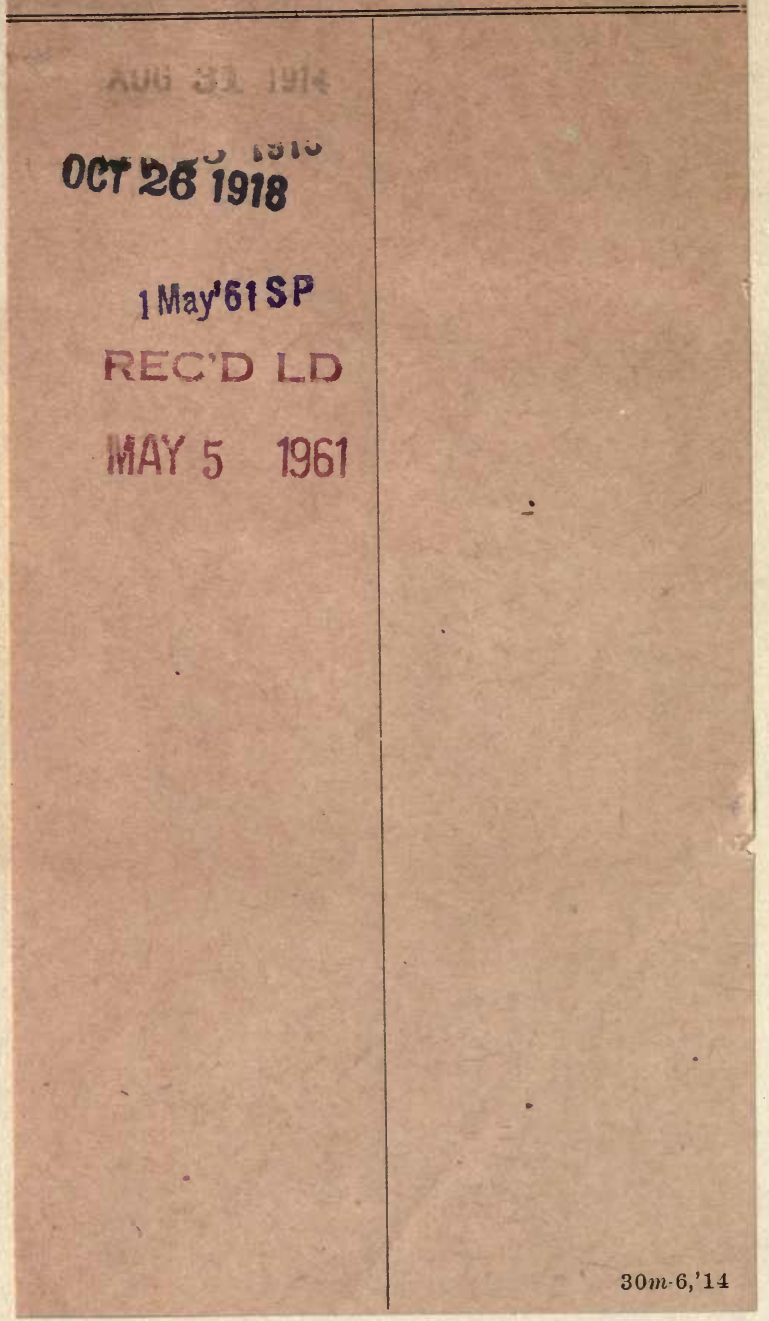


$\therefore \quad 3$

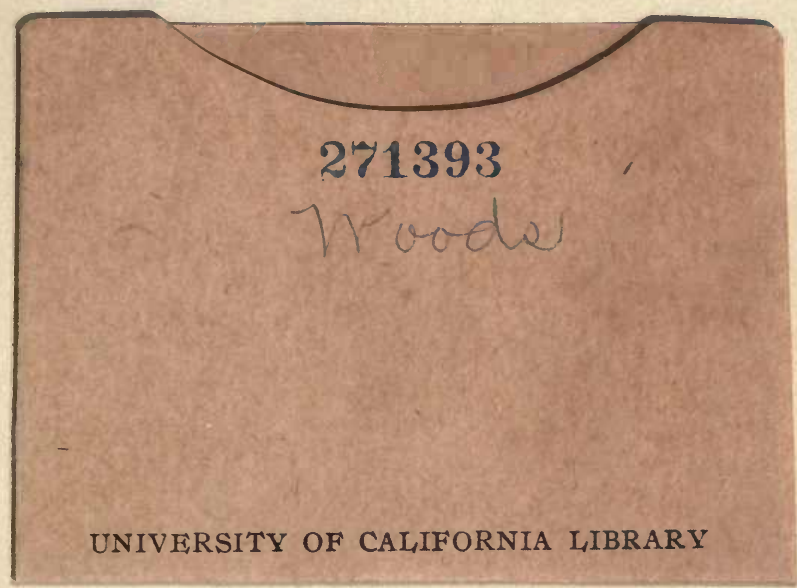


